


\section{CONSTRUIR, NAVEGAR, (RE)USAR O DOURO DA ANTIGUIDADE}

COORD.

LINO TAVARES DIAS

PEDRO ALARCÃO 


\section{Título: Construir, Navegar, (Re)Usar o Douro da Antiguidade}

Coordenação: Lino Tavares Dias, Pedro Alarcão

Design gráfico: Helena Lobo | www.hldesign.pt

Fotografia da capa: Leito do rio Douro entre Porto Manso (Baião) e Porto Antigo (Cinfães).

Fotografia de A. Loureiro Tavares, Agosto 1960.

Edição: CITCEM - Centro de Investigação Transdisciplinar Cultura, Espaço e Memória

Via Panorâmica, s/n | 4150-564 Porto | www.citcem.org I citcem@ letras.up.pt

ISBN: 978-989-8351-95-1

Depósito Legal: 450319/18

DOI: https://doi.org/10.21747/978-989-8351-95-1/cons

Porto, dezembro de 2018

Paginação, impressão e acabamento: Sersilito-Empresa Gráfica, Lda. | www.sersilito.pt

Trabalho cofinanciado pelo Fundo Europeu de Desenvolvimento Regional (FEDER) através do COMPETE 2020 Programa Operacional Competitividade e Internacionalização (POCI) e por fundos nacionais através da FCT, no âmbito do projeto POCI-01-0145-FEDER-007460. 


\section{SUMÁRIO}

INTRODUÇÃO

Lino Tavares Dias

Riconnessioni Topografiche nell'Area Archoeologica Centrale di Roma

Luigi Franciosini

Douro, um rio aquém do esquecimento

Rui Morais

Cale Callaecorum locus? Notas arqueológicas sobre a ocupação indígena e romana da Foz do Douro

António Manuel S. P. Silva

Superposición de numancias

Alfredo Jimeno Martínez

O urbanismo de Bracara Augusta: modelo e especificidades no contexto do Noroeste peninsular Manuela Martins, Jorge Ribeiro

Arqueología y desarrollo urbanístico en tres núcleos indígena-romanos: Cauca, Segovia y Termes Cesáreo Pérez González, Pablo Arribas Lobo

Ano Zero, ano 100, no territorium de Tongobriga

Lino Tavares Dias

Comprender la ciudad a través de la arquitectura: Clunia y Tiermes

Miguel Ángel de la Iglesia Santamaría, Gerardo Martínez Diez

Reflexões em torno do custo da monumentalização do espaço urbano de Bracara Augusta.

O caso do teatro: produção e custo do programa decorativo da Frons Scaenae

Jorge Ribeiro, Manuela Martins

Interpretar, Conservar, Valorizar a Ruína. Reflexões em contexto académico

Pedro Alarcão

O mundo rural romano no Vale do Douro

Pedro Pereira

Las villas romanas en Castilla y León (España): protección, investigación y puesta en valor 



\title{
INTRODUÇÃO
}

\author{
LINO TAVARES DIAS
}

Em maio de 1999 reunimos em Portugal, em Tongobriga, um conjunto de investigadores franceses, espanhóis e portugueses, com o intuito de refletirmos sobre a emergência e desenvolvimento das cidades romanas no norte da Península Ibérica. Procuramos, então, analisar, em conjunto, perspetivas que a investigação arqueológica tinha proporcionado sobre a ocupação do território do Noroeste peninsular pelos romanos no espaço da sub-meseta norte e, especificamente, na bacia do rio Douro.

Juntamos nessa mesa-redonda investigadores de várias universidades e instituições, tais como José António Abásolo Alvarez e Armando Coelho Ferreira da Silva na abordagem ao território aquando da chegada dos romanos e Manuela Martins, Lino Tavares Dias, Paulo Amaral, Ricardo Teixeira, António Colmenero, Cármen Ochoa, Santiago Carretero Vaquero, Romero Carnicero, Eusébio Gutiérrez Dohijo, Francisco Rodriguéz Morales, Carmén Garcia Merino e Maité Miro i Alaix para apresentarem os casos das urbes de Bracara Augusta, Tongobriga, Aquae Flaviae, Lucus Augusti, Gijón, Petavonium, Tiermes, Uxama Argaela e Tarraco.

A abordagem a Numância, embora programada, não foi possível por falecimento de José Luís Argente Oliver, arqueólogo que tinha trabalhado durante décadas sobre aquele sítio. A coordenação global dos debates foi dinamizada por Jorge de Alarcão e Patrick Le Roux.

Os resultados dessas reflexões foram publicados, ainda em 1999, em atas, sob o título Emergência e Desenvolvimento das Cidades romanas no Norte da Península 
Ibérica. Desde então despertou-se o desejo de incrementar novos debates, o que veio a ocorrer em março de 2007, em Zamora.

Se em 1999 refletimos sobre a emergência das cidades, no encontro do primeiro trimestre de 2007 começamos a perspetivar a bacia do Douro como um «espaço paisagem» que o homem foi marcando, evidenciado pela construção com as suas artes de viver e estratégias de uso. Nos debates programados para 2007 preocupamo-nos não só com a edificação de cidades no século I e II depois de Cristo mas, também, com os momentos posteriores, até à atualidade, constituindo na contemporaneidade a «paisagem cultural» cuja gestão compete às entidades públicas de Portugal e de Castela e Leão.

O desafio a que nos propúnhamos responder era suportado em três momentos cronológicos, vulgarmente denominados por «épocas»: a romana; a medieval e a contemporânea desde o final do século XX.

A perspetiva de transversalidade cronológica desafiava a que todos os intervenientes aprendessem com todos, por mais díspares que parecessem as épocas de interesse individual. Todos procurávamos conhecer melhor as «novidades científicas» para apreendermos melhor a longa construção do território.

Entretanto, a publicação e reconhecimento da Convenção Europeia da Paisagem, veio ajudar a alicerçar alguns conceitos que estavam em discussão e a "paisagem construída ao longo dos séculos» foi formalmente assumida como «fruto do casamento do trabalho do homem e da natureza».

Assim, o "património construído pelo homem» é hoje estudado porque torna-se «evidente aos nossos sentidos», vulgarmente denominado «arquitetónico» ou, então, porque «é tornado evidente» por metodologia arqueológica, vulgarmente denominado «arqueológico». O trabalho complementar entre arqueólogos e arquitetos passou a ser articulado, por vezes indissociável, em importantes sítios arqueológicos patrimoniais, os quais foram, por vezes, assumidos como símbolos nacionais durante o século $\mathrm{XX}$.

E foi todo este património identificado no espaço geomorfológico da bacia hidrográfica do Douro que analisamos, reunindo arqueólogos, historiadores, geógrafos, arquitetos, gestores de território e todas as outras distintas especialidades preocupadas em perceber a construção milenar deste território.

Como objetivos gerais, entendidos como preocupações para quem tem responsabilidades de investigação e de gestão, procuramos compreender as marcas que o homem deixou nos lugares em que esteve e reconhecer as influências dessas marcas na história e na conformação do homem ao longo dos séculos, especialmente desde Estrabão até à atualidade.

Para aprofundar esta especificidade reunimos em Zamora, em março de 2007, os investigadores Alfredo Jimeno Martínez, Angel Morillo Cerdán, Armando Coelho Ferreira da Silva, António Lima, Carmén Garcia Merino, Francês Tusset Bertrán, José Javier Fernández Moreno, Lino Tavares Dias, Miguel Angel de la Iglesia Santa- 
maria, Milagros Burón Alvarez, Miguel Rodrigues, Paulo Amaral, Ricardo Teixeira e Victoria Romero Carnicero.

Pela primeira vez em conjunto, começou a perspetivar-se a possibilidade de ter existido na época romana uma estratégia política e económica para toda a região do norte da Meseta, fortemente marcada pelo rio Douro e pela sua bacia hidrográfica. A discussão cresceu com o reconhecimento de um documento da autoria do Imperador Augusto, datado de 15 a. C., em que trespassava a hipótese política de poder existir uma província transduriana, que assumia o rio Douro como espinha dorsal.

Neste planeamento estratégico e político, o poder económico e administrativo romano procuraria integrar as zonas mais periféricas, e morfologicamente montanhosas, com muitos solos agrestes e pouco propícios ao cultivo intensivo que a economia dos romanos valorizava.

Os resultados das reuniões científicas foram reunidos em publicação sob o título Património cultural y território en el Valle del Duero, editado em 2010 pelo Ministério da Cultura português e pela Junta de Castilla y León.

Entretanto, a investigação e as intervenções foram decorrendo a diferentes níveis, agregando investigadores, arqueólogos e arquitetos, que continuaram, ao longo de anos, a trabalhar sobre aqueles sítios patrimoniais. Gradualmente integraram-se jovens investigadores que perspetivam novas problemáticas e que enriquecem os debates.

A intervenção no território da bacia do Douro também tem sido enriquecida pela crescente aposta na valorização do Património, quer pela assunção política quer pelo reconhecimento social.

Era, por isso, muito oportuno, analisar a situação do conhecimento em 2017.

O CITCEM, Centro de Investigação Transdisciplinar Cultura, Espaço e Memória da Faculdade de Letras da Universidade do Porto, quis fazê-lo, contando com a colaboração do CEAU, Centro de Investigação da Faculdade de Arquitetura, do Instituto Superior Politécnico de Gaya, da Direção Regional do Norte do Ministério da Cultura, da Câmara Municipal de Gaia e da Dirección General de Patrimonio de la Junta de Castilla y Léon.

Assim, com o título Construir, Navegar, (Re)Usar o Douro da Antiguidade, realizou-se, de 26 a 30 de outubro de 2017, um Encontro que reuniu arqueólogos, arquitetos e investigadores que têm trabalhado ao longo das últimas décadas sobre as cidades romanas da bacia do rio Douro, escavando-as e valorizando-as, mas, também, perspetivando o ordenamento político e económico do território do norte da meseta em que se integravam.

Procurou-se que fossem evidenciadas algumas sínteses do conhecimento mas, também, reflexões sobre projetos previstos para intervenções noutros sítios, em especial para Roma.

Na primeira parte integraram-se contributos de reflexão sobre enquadramentos e problemáticas gerais: 
Luigi Franciosini - Riconnessioni Topografiche nell'Area Archeologica Centrale di Roma;

Armando Coelho F. Silva - A ocupação e organização do território aquando da chegada dos romanos;

Rui Morais - Douro, um rio aquém da memória;

António Silva - Cale Callaecorum locus? Lugares e povos pré-romanos do Baixo Douro à luz da história e da arqueologia.

$\mathrm{Na}$ segunda parte foram apresentados resultados de investigações e projetos específicos sobre cidades romanas:

Alfredo Jimeno Martínez - Numancia: Nueva Interpretátion estratigráfica;

Manuela Martins - O urbanismo de Bracara Augusta: modelo e especificidades no contexto do NO peninsular;

Cesáreo Pérez González; Pablo Arribas Lobo - Arqueología y desarrollo urbanístico en tres núcleos indígena-romanos de la cuenca del Duero: Cauca -Segovia-Tiermes;

Francesc Tuset Bertran - Clunia: una nueva historia de la ciudad a la luz de las recientes investigaciones;

Lino Augusto Tavares Dias - Ano Zero, ano 100, no territorium de Tongobriga; Miguel Ángel de la Iglesia Santamaría - Compreender la ciudad a través de la arquitectura: Clunia y Tiermes;

Jorge Ribeiro - A monumentalização do espaço urbano de Bracara Augusta. Aproximação à economia da construção;

Sérgio Carneiro - Técnicas construtivas nas Termas Medicinais Romanas de Chaves;

Pedro Alarcão - Interpretar, Conservar, Valorizar a Ruína. Reflexões em contexto académico.

$\mathrm{Na}$ terceira parte procurou-se fazer a abordagem ao mundo rural na bacia do Douro, perante os resultados de investigações recentes.

Pedro Pereira - O mundo rural romano no Vale do Douro;

Margarita Sánchez Simón - Las villas romanas en Castilla y León: protección, investigación y puesta en valor.

As sessões do ENCONTRO realizaram-se na Casa Allen, no Porto, no Convento Corpus Christi, em Gaia, e no Yacimiento Arqueológico de Tiermes.

Os resultados das reflexões e debates apresentados no Encontro, em outubro de 2017, foram reunidos neste livro.

Para a sua concretização devemos palavras de reconhecimento às coordenadores do CITCEM, Professoras Cristina Cunha e Amélia Polónia, ao coordenador do CEAU, Professor Rui Póvoas, a Marlene Cruz e a Vasco Sistelo, bolseiros no CITCEM que garantiram criteriosa ajuda, quer no secretariado do Encontro quer nesta publicação. 


\title{
RICONNESSIONI TOPOGRAFICHE NELL'AREA ARCHOEOLOGICA CENTRALE DI ROMA
}

\author{
LUIGI FRANCIOSINI*
}

Unialba su Roma vista dal Gianicolo - l'alto colle che domina da ponente la riva destra del Tevere - può essere una esperienza importante per la comprensione della città: il cielo, lievemente nuvoloso, e la nebbia sul fiume [...] Le sagome ad Est dell'Appennino centrale e del Vulcano dei Colli Albani fanno da sfondo ai sette colli di Roma. Contemplando il panorama da questo rilievo si ha la possibilità di comprendere come la storia e la cultura di questa grande città sono indissolubilmente connesse alla struttura geologica del suo territorio.

Renato Funiciello, I sette colli: guida geologica a una Roma mai vista

Il nostro intento era quello di comprendere la natura topografica dell'Area Archeologica Centrale e di via dei Fori Imperiali. Un'esperienza che avrebbe preso consapevolezza a partire dall'osservazione della morfologia del luogo, del rapporto tra valli alluvionali e banchi tufacei sommitali, tra il Tevere e i colli Quirinale, Viminale, Palatino e Campidoglio; dall'identificazione dei grandi recinti monumentali e degli antichi quartieri residenziali.

Era necessario partire dalla descrizione topografica: da un lato sperimentare concretamente il sito, distinguendo i versanti acclivi dalle spianate; dall'altro immaginare

\footnotetext{
* Arquitecto. luigi.franciosini@uniroma3.it.
} 
l'invisibile struttura materica del sottosuolo e quella brusca frattura altimetrica che si era formata sul Paleo Tevere, limite tra i pantani insalubri delle valli e i pianori soleggiati; tra limi, sabbie, ghiaie e depositi vulcanici di tufi e pozzolane.

Losservazione iniziò dall'Argiletum, l'attuale via Madonna dei Monti, unantica via dall'andamento rettilineo ma nervoso (come accade quando un ruscello precipita a valle), collegamento naturale tra i pianori sommitali, che si distendono ad Est e la valle del Tevere ad Ovest; tra la Suburra, i Fori Imperiali ed il Foro Romano.

La strada discende dai colli Quirinale e Viminale, seguendo la conformazione orografica del sito: un andamento dettato dallessere stata prima che una strada un impluvio, uno scolo naturale discendente verso il Tevere: un solco divenuto dapprima tratturo, poi sentiero, infine invaso stradale stretto tra i fronti delle case a schiera e dei palazzetti seicenteschi, cresciuti sulle fondamenta dell'antico quartiere della Suburra.

Percorremmo l'Argiletum in direzione di ponente, volgendo lo sguardo verso la torre del Campidoglio e l'antica Arce. Raggiunta l'estremità meridionale della via, laddove si fa piana e da invaso cambia in slargo aprendosi sul paesaggio delle rovine dei Fori Imperiali, d'improvviso il tracciato s'interruppe, impedendoci di proseguire. Ci trovammo a ridosso della prima trincea archeologica: uno scarto topografico, una voragine, si apriva di fronte a noi (tra la Torre dei Conti e il muro del Foro di Augusto), segnalandoci il limite fisico e giuridico d'espansione dell'Area Archeologica Centrale: in fondo nient'altro che un luogo inaccessibile, invalicabile, riservato.

Da lì, ad una quota più bassa di almeno 5-6 metri dal piano di calpestio della strada medioevale, si apriva la visione del Foro Transitorio: il Foro di Nerva. Affioramenti di strutture archeologiche; frammenti lapidei sparsi sul parterre; schegge di marmi appartenenti ad elementi architettonici frantumati e dispersi, si offrivano alla nostra osservazione sullo sfondo della rinascimentale via Alessandrina. E poi, in quella moltitudine di frammenti, di spazialità interrotte, incomprensibili e senza tempo, lungo il muro di contermine che si eleva tra il Foro Transitorio e quello della Pace (il grande giardino recinto gemente sotto il suolo moderno di Largo Corrado Ricci) apparvero, solenni, scultoree, le colonnacce del Foro di Nerva.

Più in fondo, oltre i tracciati della via Alessandrina e di via dei Fori Imperiali, spinte al di là delle aiuole che bordano la sede stradale moderna, ci apparvero, irraggiungibili, la sagoma severa dell'antica Curia e, più ad occidente, la chiesa Accademica dei SS. Luca e Martina, costruita ai piedi del Campidoglio, nell'allora quartiere dei Pantani, oggi distrutto.

Quel nome, Foro Transitorio, doveva pur significare qualcosa; riferendosi alla sua originaria funzione di piazza-corridoio, appunto, di passaggio monumentale tra la Suburra e il Foro Romano. Funzione svolta in precedenza dalla via dell'Argileto, di 
cui il Foro Transitorio occupò l'ultimo tratto. Un invaso che, grazie alla sua posizione topografica, venne ad assumere il ruolo di raccordo urbano tra i Fori Imperiali e il complesso del Foro Romano.

Quest'ultimo, sino al secolo scorso, portava il nome non aulico, ma suggestivo, di Campo Vaccino.

Una lunga tradizione, pittorica e letteraria, ci descrisse questo luogo come un paesaggio in cui la magnificenza della rovina incontrava l'umana e quotidiana sopravvivenza.

Di fronte a noi si mostrava un paesaggio contraddittorio, difficile da interpretare e da percorrere.

A nulla valsero le spiegazioni, il ragionare per cercar di comprendere; a nulla valse domandarci quali sconvolgimenti fossero avvenuti tanto da restituire un luogo, un paesaggio, una spazialità di indecifrabile complessità e bellezza. A nulla valse il tentare di identificare le emergenze topografiche del luogo (il Campidoglio, la collina dei Palazzi Imperiali, gli avanzi della Collina Velia, la valle del Colosseo e il Velabro); a nulla valse l'individuare contrappunti monumentali (Piazza Venezia e lo stradone di Via dei Fori, da un lato, e l'arco di Tito e quello di Settimio Severo e il Tabularium, dall'altro).

In quel paesaggio di rovine e di contrasti, dove tutto partecipava disordinatamente (in un solo momento) a narrare, strato dopo strato, il tempo millenario, nulla poté di fronte all'impotenza del sentire, all'impossibilità di porre ordine, di procedere e di sperimentare.

Ciò di cui eravamo testimoni era non solo la difficoltà oggettiva di avanzare nei territori di questa città di trincea (potenziale espansione della città di superficie) ma anche quella di immaginarla ed evocarla: l'antichità non ci è data in consegna di per sé -non è lì a portata di mano- al contrario tocca proprio a noi saperla evocare.

La comprensione del passato non è mai un evento neutro: è un'attività critica prodotta dalla memoria che, sollecitata dall'esperienza, garantisce il suo continuo rinnovamento.

In quel groviglio di lasciti in vista sul parterre archeologico (un'elencazione di forme e materie separate dagli scavi archeologici, rincorrendo la lucida meccanica stratigrafica, dall'alto al basso, dal più moderno al più vecchio, ma che includeva incidenti tanto da sovvertirne il principio d’ordine), ciò che si rilevava era l'assenza di ogni strategia progettuale, interpretativa, in grado di porre in evidenza criteri restitutivi, in grado di aiutare la fruizione e la comprensione.

Risalimmo lungo il muro del Foro di Augusto fino a raggiungere l'Arco dei Pantani: una porta centinata, dalla quale è possibile scorgere, inaspettata, tra gli ingranaggi murari in opera quadrata di peperino grigio, incorniciata dalla ghiera dell'arco in travertino, la sagoma marmorea del tempio di Marte Ultore, le cui 
sostruzioni tufacee sprofondano ancora di qualche metro rispetto alla quota della città medioevale, rendendo così impossibile ogni via d'accesso.

$\mathrm{Ci}$ affacciammo e osservammo, per poi procedere a ritroso su via Baccina, nel cuore del quartiere della Suburra. Ė questa una parallela di via Madonna dei Monti, ma spostata più a Nord, risalendo di un isolato le pendici del colle Quirinale.

Da qui rivolgemmo lo sguardo a ponente verso larco e il foro. Trovammo collimazioni e corrispondenze tra l'antica via e l'arco; tra l'arco e il tempio; e infine tra l'arco, il tempio e la cupola della chiesa dei SS. Luca e Martina, spinta laggiù sul fondo della prospettiva.

Quando, eretta la colonna dell'imperatore d'Oriente Foca, le grandi piazze monumentali, depredate prima e abbandonate poi, furono man mano ricolmate dai limi depositati dalle piene del Tevere, sui lacerti marmorei delle antiche pavimentazioni, si andarono a fondare gli ambienti di sotterraneo delle fabbriche rinascimentali del quartiere Alessandrino.

È così che l'Arco dei Pantani divenne porta urbana di un quartiere di case e chiese, sorto tra la collina Velia e piazza Venezia. Un quartiere popolare, ordinatamente pianificato, costruito sui resti monumentali dei recinti e sui riempimenti medioevali, attraversato da via Bonella, una direttrice che da Est, dalla Suburra, conduceva alla chiesa di SS. Luca e Martina, cresciuta tra l'antica Curia e le botteghe del Foro di Cesare e l'arco di Settimio Severo.

Quella strada avrebbe condotto la città cresciuta sui colli Quirinale e Viminale ad Ovest: a Santa Maria della Consolazione al Velabro e, infine, al Tevere.

Più a sud, posto sulla sommità della Velia, vi era il bellissimo giardino rinascimentale della villa Silvestri Rivaldi, con le sue fontane, gradinate, criptoportici: un giardino terrazza, un luogo sublime dal quale ammirare il panorama della vista del Foro, del Palatino, della Basilica di Massenzio e dei quartieri che man mano si erano addensati intorno al centro monumentale di Roma.

Di questa città stretta tra l'Est e l'Ovest, tra il fiume e i colli, innervata da vie e vicoli che scorrevano da levante a ponente, non rimane più memoria, più possibile esperienza. Ė prevalso lo scorrimento veloce di via dell'Impero (che tutto travolse, con l'insanabile trasformazione della topografia e morfologia del centro monumentale di Roma) tracciatatra Sud e Nord, tra il mare e Piazza Venezia. Un contrappunto percettivo e simbolico (di ineguagliabile scenografica eloquenza) allantica via Sacra che, poco più in là, piccola, tra i resti memorabili dei monumenti antichi, sarrampica sulla Velia.

\section{RIQUALIFICAZIONE E RISIGNIFICAZIONE DI VIA DEI FORI IMPERIALI DA PIAZZA VENEZIA AL COLOSSEO: STRATEGIE D'INTERVENTO}

Ogni intervento di risignificazione dellesistente deriva da un insieme di attività critiche e di riflessioni disciplinari. Un insieme di specificità ed attenzioni che, nel 
loro coniugarsi, siano capaci di restituire un'immagine autentica, discreta ed evocativa dell'oggetto indagato: autentica nel riconoscere le diverse identità che si sono depositate nello spazio attraverso la materia del tempo; discreta nell'affermare la priorità del racconto storico, della narrazione sull'azione creativa; evocativa nell'assicurare il prolungamento della memoria.

Infine, un'immagine capace di accogliere l'istanza di riattualizzazione.

Ogni ipotesi di nuovo assetto di un centro urbano non può non avere riflessi e non chiedere coerenza con la struttura e la forma complessiva della città. Questa considerazione è valida in particolare per l'AACR, in quanto, nei suoi sviluppi antichi e moderni, rappresenta il nucleo evocativo e funzionale dal quale si dipartono grandi arterie che si irradiano nell'area metropolitana. Tra queste prendono particolare rilevanza quelle che hanno determinato lo sviluppo della città sul quadrante sud-orientale seguendo due direttrici: l'antica via Appia e la moderna via Cristoforo Colombo e il suo sviluppo verso il mare.

L'Area Archeologica Centrale di Roma, nel suo processo storico, deriva dalla sovrapposizione di diverse idee di spazio urbano, ognuna coerente con modelli ideologici e culturali che si sono susseguiti nel tempo. Dalle spazialità articolate in strette sequenze, punteggiate da episodi monumentali, che si succedono assecondando la modellazione orografica del suolo, all'apparizione della rovina, vagante nella dimensione estraniata dei campi, segno del trapasso dall'antichità al medioevo. È questa un'immagine persistente nel tempo dalla quale prenderà forma il paesaggio delle ricostruzioni parlanti e dell'archeologia.

Al paesaggio delle rovine evocanti, che induce ad un attraversamento lento del luogo, punteggiato da scorci e vedute, segue un'interpretazione dello spazio urbano segnata da un'idea di visione simultanea, per ottenere una sequenza cinetica, veloce, meccanica. Tre diversi modi di percepire la forma urbana ognuno dei quali è caratterizzato da una propria specifica modalità percettiva.

L'insieme restituisce una struttura stratificata di difficile interpretazione: un palinsesto narrante costituito dalla sovrapposizine di parti, dominato dalla frammentazione e dalla discontinuità, topografica, spaziale e materiale.

L'insieme di questo complesso organismo può essere descritto attraverso quattro scenari oggetto d'indagine: la forma del suolo; la forma della città antica; la forma delle città medievale e papale; la forma della città moderna, da Roma Capitale ad oggi.

\section{Le strategie d'intervento}

La strategia proposta prevede di stabilire delle relazioni ordinate ed evocanti tra gli invasi della città antica e le forme delle «altre città» che ad essa si sono sovrapposte.

Le proposte progettuali rispondono a quattro categorie d'intervento: riorganizzazione, riconnessione, evocazione e valorizzazione. 
Riorganizzazione ed allontanamento del traffico veicolare da via dei Fori Imperiali, via di San Gregorio e via dei Cerchi a favore di una mobilità pubblica su ferro (metropolitana), riservando la fruizione di superficie ad una mobilità lenta.

Lo spazio pubblico viene ripensato come l'insieme dei luoghi (percorsi, piazze, parchi, giardini ed aree archeologiche) ad esclusivo uso ciclo-pedonale. In questa logica Via dei Fori Imperiali e Via Alessandrina confermano il loro ruolo di infrastrutture strategiche nella organizzazione della mobilità di superficie.

Riconnessione degli invasi attraverso la ricucitura dello «strappo altimetrico» tra le quote archeologiche, le quote moderne e le aree di bordo contemporanee, identificando quattro «porte» di accesso: Porta Capena, a sud; Largo Corrado Ricci, ad est; Piazza Venezia, a nord; il Velabro, ad ovest.

Sono previsti inoltre interventi di ampliamento e ridefinizione degli scavi in modo da potenziare la leggibilità degli invasi dei Fori Imperiali.

Evocazione della spazialità e del carattere storico-architettonico del luogo attraverso la ridefinizione dei rapporti di continuità spaziale e temporale tra le città stratificate, nellobiettivo di restituire identità e riconoscibilità alle parti costituenti la forma urbana.

Valorizzazione funzionale mediante l'organizzazione di servizi didatticoinformativi e museali propedeutici alla fruizione, privilegiando il restauro, il recupero e la rifunzionalizzazione degli edifici storici e delle strutture archeologiche.

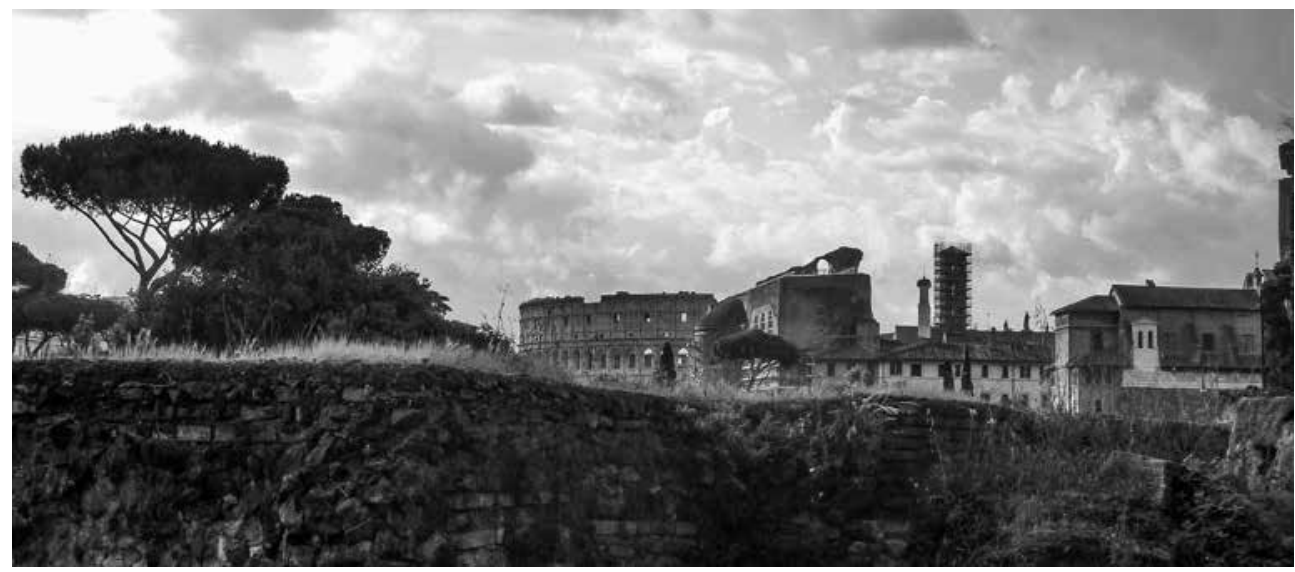

Fig. 1. Il coronamento dell'Anfiteatro Flavio emerge dalle creste delle mura del foro di Cesare. 


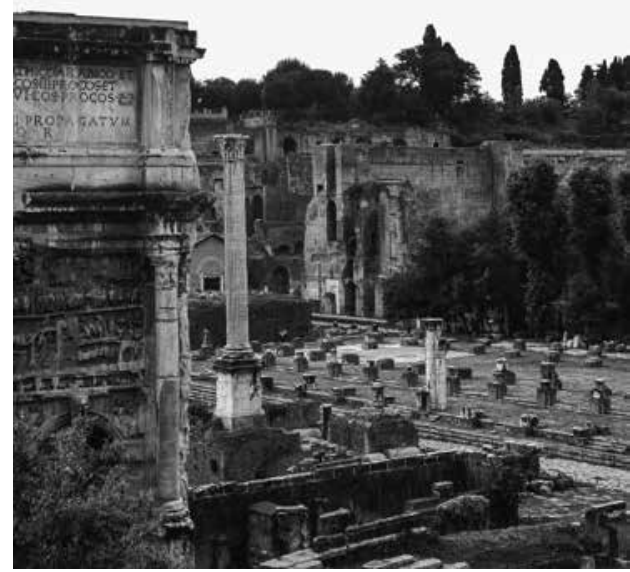

Fig. 2. II carattere topografico dell'area ed il rapporto valli e pianori: il Foro Romano ed il Palatino.

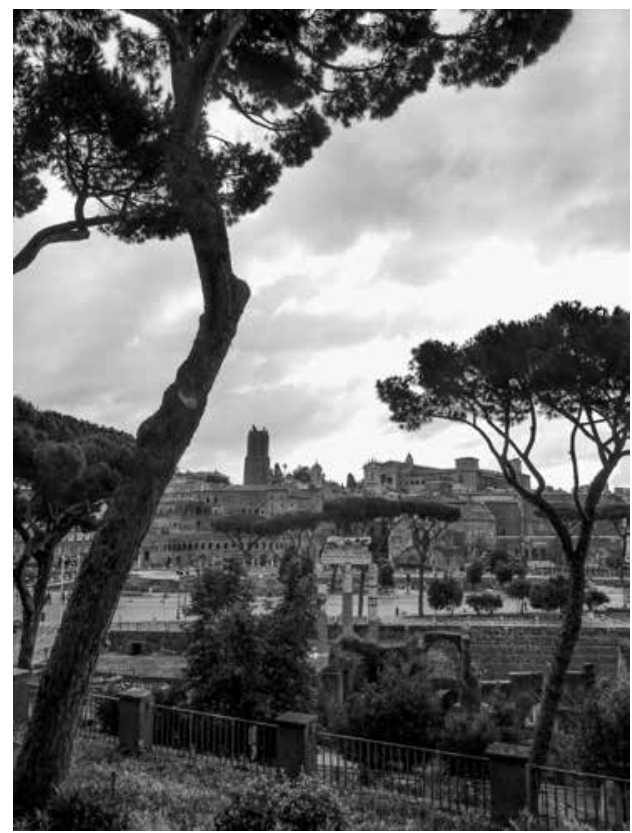

Fig. 3. Veduta da ovest dell'Area Archeologica Centrale. In successione: il Foro di Cesare, via dei Fori Imperili, i mercati Traianei.
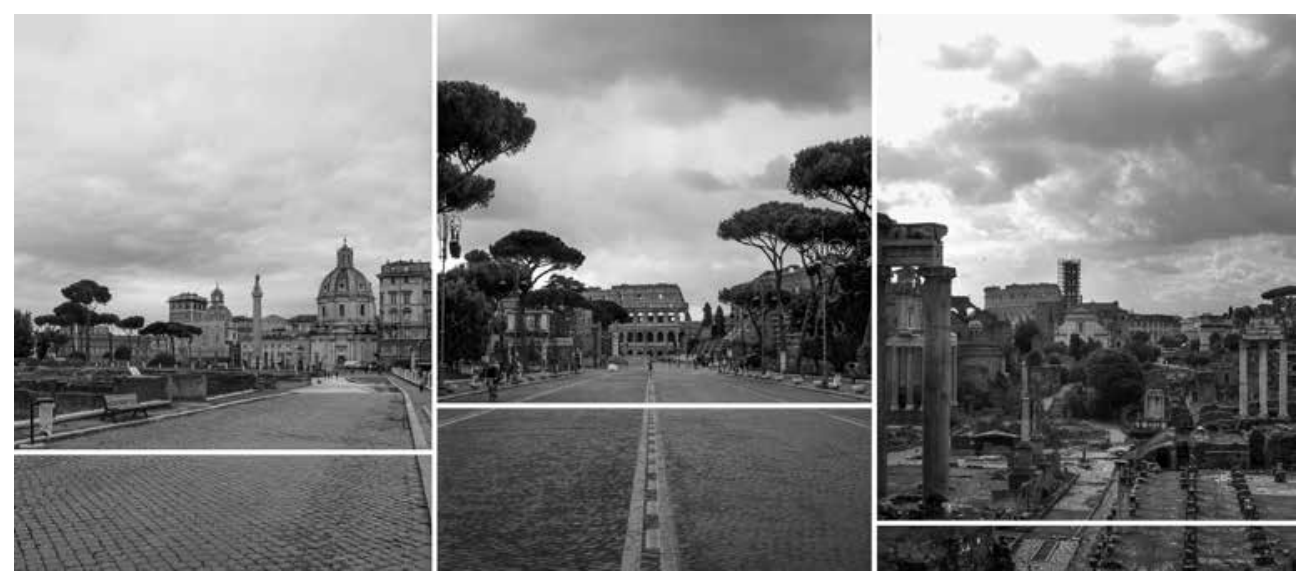

Fig. 4. L'area archeologica centrale: tre paesaggi, tre quote e tre strade. In ordine: la via Alessandrina ed il paesaggio della Roma Rinascimentale; la via dei Fori Imperiali e il paesaggio della Roma moderna; la via Sacra, il Foro ed il paesaggio della Roma repubblicana e imperiale. 


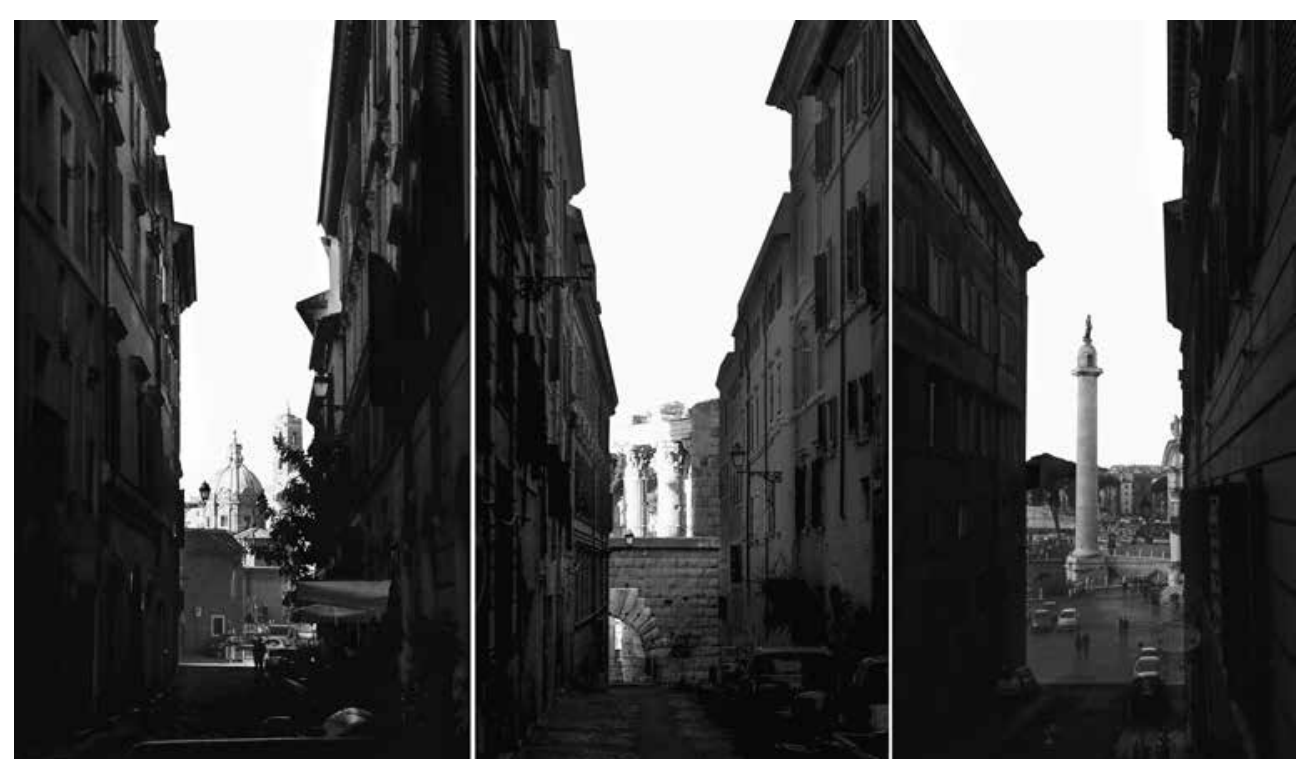

Fig. 5. Le direttrici trasversali di collegamento tra i colli (Esquilino, Quirinale) e la valle occupata dall'Area Centrale: via Madonna dei Monti, via Baccina, via Magnanapoli.

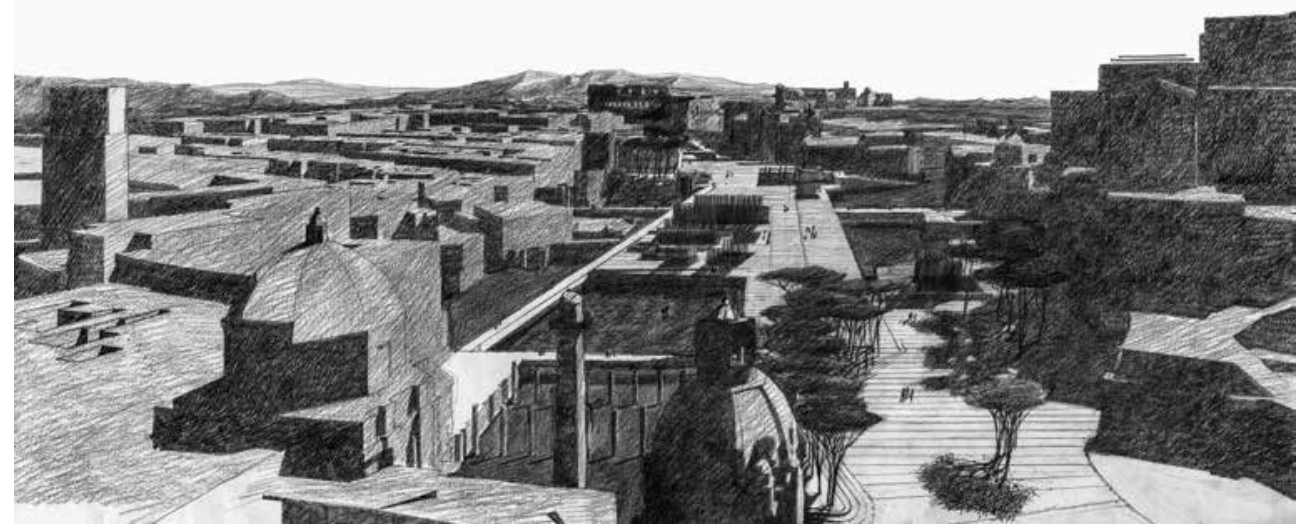

Fig. 6. Veduta dall'alto del nuovo assetto proposto per Via dei Fori Imperiali, da piazza Venezia in direzione del Colosseo. 


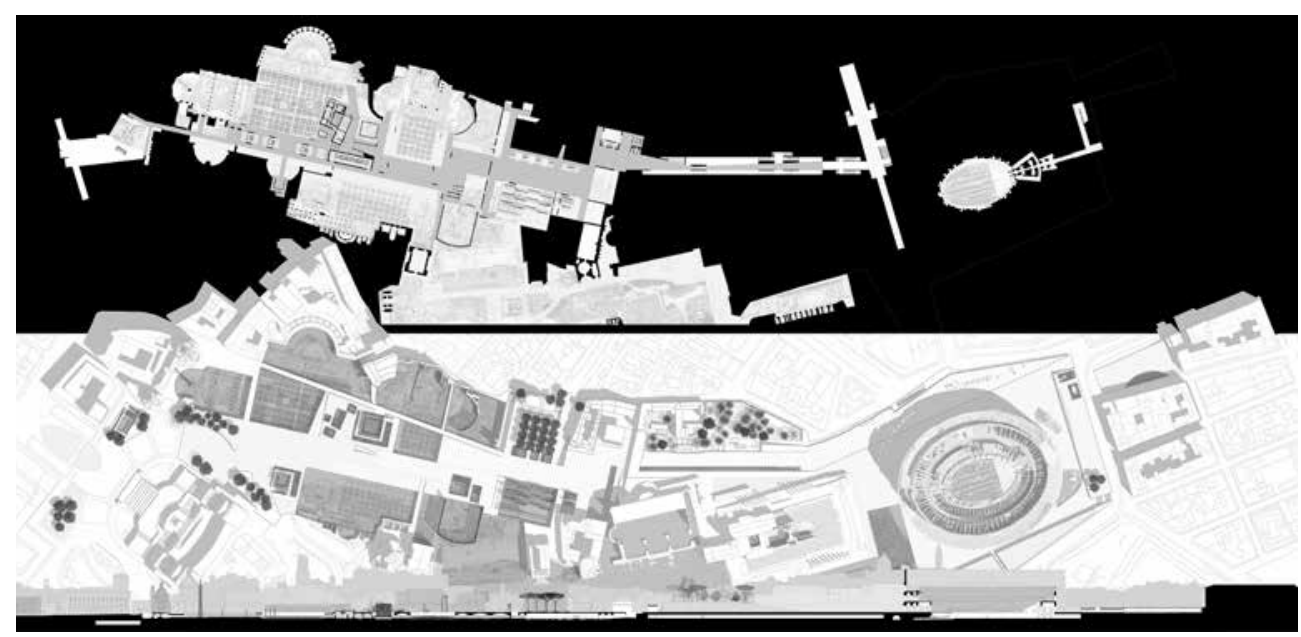

Fig. 7. Planimetria di assetto generale: la quota archeologica e la quota urbana. Sezione longitudinale lungo via dei Fori Imperiali.

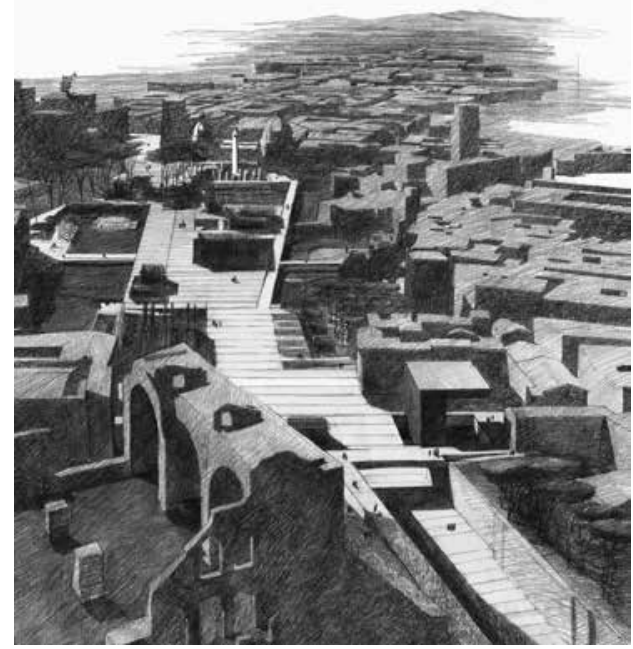

Fig. 8. Veduta dall'alto del nuovo assetto proposto per Via dei Fori Imperiali, dalla Basilica di Massenzio in direzione di piazza Venezia.

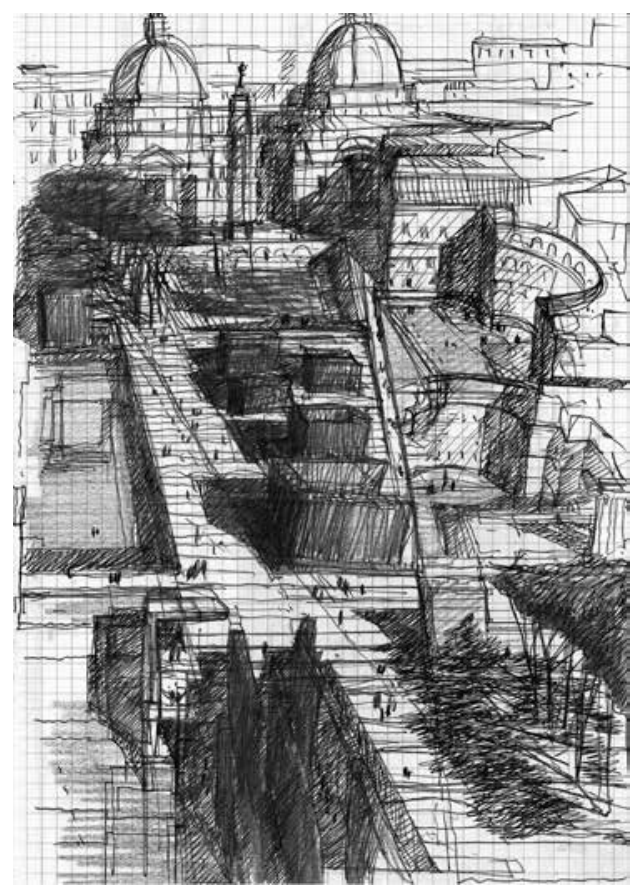

Fig. 9. Disegno di studio per il nuovo assetto di via dei Fori Imperiali. 


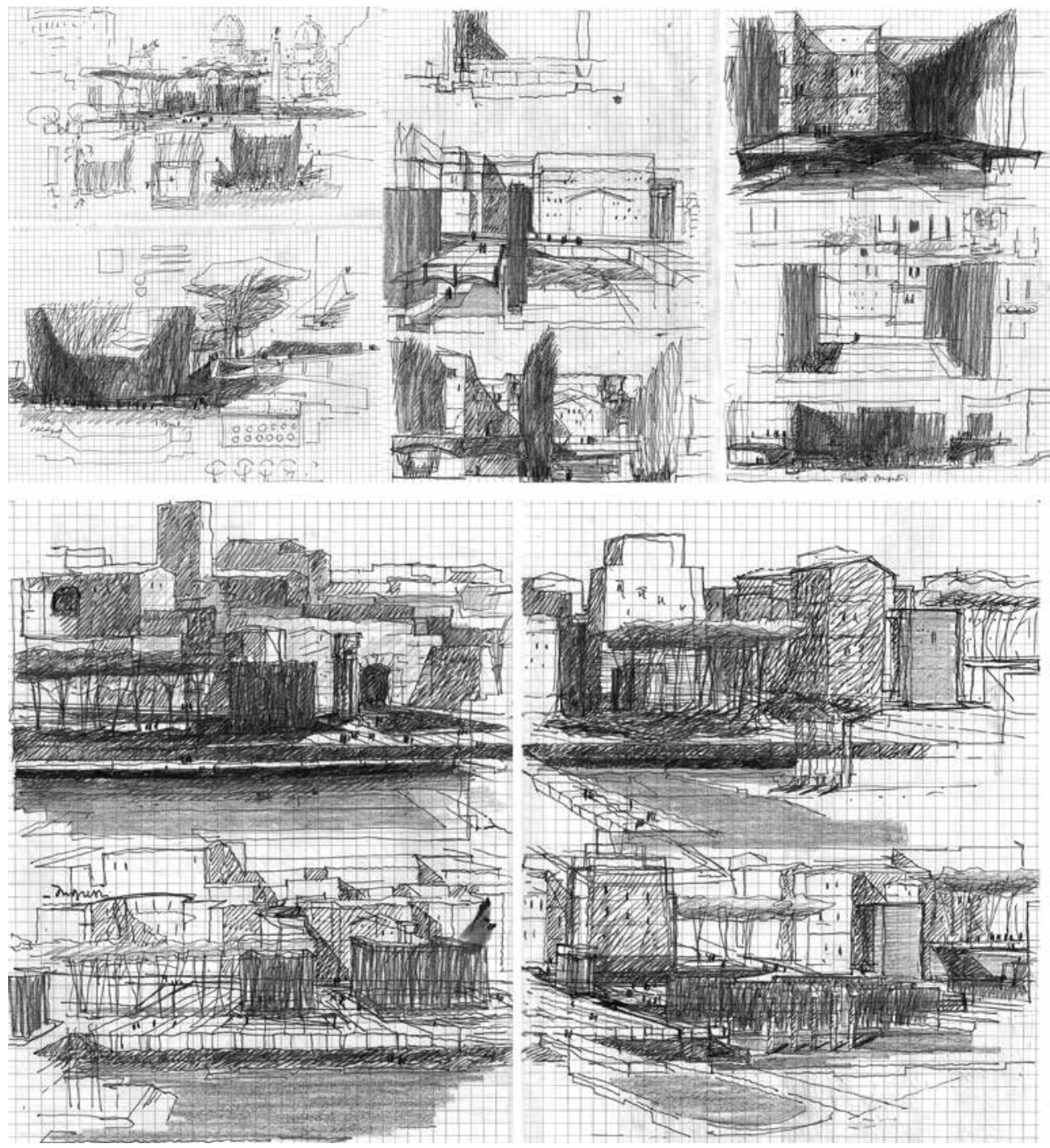

Fig. 10. Disegno di studio per il nuovo assetto di via dei Fori Imperiali. Il sistema del verde. 


\section{DOURO, UM RIO AQUÉM DO ESQUECIMENTO}

RUI MORAIS*

E (o Douro) é, no mapa da pequenez que nos coube, a única evidência incomensurável com que podemos assombrar o mundo.

Miguel Torga, Portugal

\section{O DOURO SEGUNDO AS FONTES LITERÁRIAS}

Não se pode pensar no rio Douro em época romana sem fazer uma breve alusão ao processo de conquista que decorreu a partir do século II a. C. na fachada atlântica. $\mathrm{O}$ conhecimento dos territórios junto à orla costeira era estratégico, pois estavam situados num dos circuitos naturais de navegação e, consequentemente, numa área de confluência de culturas, pelo menos desde a Idade do Bronze ${ }^{1}$. Assim o testemunham os périplos de Hanão e Himilcão que, desde Cádis, marcavam as rotas norte e sul do Atlântico em busca de ouro, marfim, cobre, estanho e âmbar. Este último périplo tem sido interpretado como representativo da reabertura da rota do estanho até às Oestrímnides ou Cassitérides («ilhas de estanho»), com o fim de renovar o seu

* FLUP/ID\&CECH. rmorais@letras.up.pt.

${ }^{1}$ MORAIS, 2005; ARRUDA \& VILAÇA, 2006: 31-58. 
comércio, que, controlado desde o Bronze Final pelos grupos autóctones do sudoeste, se tinha interrompido no século VI a. C. ${ }^{2}$.

Não surpreende assim que mais tarde os Gaditanos, profundos conhecedores destas paragens, se tivessem associado aos generais romanos na conquista gradual deste território atlântico e nela tivessem tido um papel crucial. Vários foram os generais romanos que direta ou indiretamente estiveram implicados neste processo. De modo breve, iremos mencionar alguns dados referidos nas fontes.

O primeiro que nos merece destaque foi Q. Servílio Cepião, que efetuou as primeiras expedições ao Noroeste no contexto das Guerras Lusitanas. Neste âmbito, crê-se que os gaditanos tenham prestado auxílio logístico e naval quando este general decide, em 139 a. C., um ataque conjunto contra Viriato, a sul, e a «devastação dos campos do Galaicos», a norte ${ }^{3}$.

Pouco tempo depois, em 137 a. C., ocorrerá o famoso avanço de D. Júnio Bruto até ao norte da Península. Mais uma vez esta expedição punitiva parece ter contado com o apoio da cidade de Cádis como base naval e de apoio às tropas romanas. Este feito ficará registado nos anais da história como aquele que lhe deu o epíteto de «Galaico» e que assinala a passagem do célebre rio Léthes, à semelhança do rio do esquecimento da mitologia clássica. As fontes clássicas referem que se tratou de uma hábil artimanha das tribos galaicas para conter o avanço das tropas romanas; outra leitura pode, todavia, ser feita: as tropas romanas, cansadas destas campanhas punitivas e na perspetiva de terem que enfrentar uma guerra de guerrilha com conceitos e táticas diferentes das romanas, deixaram correr o rumor da existência, naquelas terras, do rio do esquecimento ${ }^{4}$. Este confronto, teria tido lugar a 9 de julho de 137 a. C., data que foi comemorada em Roma pela construção de um templo a Marte ${ }^{5}$ erigido no Campus Martius, dois ou três anos mais tarde ${ }^{6}$. Segundo Orósio - que nos dá seguramente números exagerados - este confronto teria causado a morte a cerca de 50 mil galaicos e feito 6 mil prisioneiros, tendo apenas conseguido fugir 4 mil. A partir deste momento, os galaicos passaram a ficar sob o controlo teórico da Hispania Ulterior ${ }^{7}$.

É ainda tentador associar um dos nomes de difícil leitura expresso no Pro Balbo de Cícero (Cássios ou Crassos) a P. Licínio Crasso que, como procônsul, comandou de 96 a 94 a. C., uma nova expedição em terras do noroeste. Esta campanha, no seguimento da sua intervenção na Lusitânia para interditar os sacrifícios humanos e reprimir o retorno da sua agitação, teve um significado singular no contexto do

\footnotetext{
${ }^{2}$ MORAIS, 2005.

${ }^{3}$ MORAIS, 2007a: 102.

${ }^{4}$ MARTÍNEZ MERA, 2001: 306, nota 33.

${ }^{5}$ TRANOY, 1981: 128.

${ }^{6}$ BLANCO FREIXEIRO, 1992: 97.

${ }^{7}$ MORAIS, 2007a: 102.
} 
comércio romano porque, daí em diante, permitiu aos negotiatores de Roma a abertura de novos horizontes para a exploração das riquezas mineiras nesta área da península ${ }^{8}$. De fato, como indica Estrabão (III 5.11), Crasso ficou responsável por «ensinar»a rota para o abastecimento de grandes quantidades de minério. Esta exploração possibilitou o enriquecimento pessoal e da sua família que passou a ser uma das mais abastadas e influentes de Roma9.

Mas o momento mais significativo e que diretamente diz respeito à tomada de Cale é o da expedição de M. Perpena em 74 a. C. Esta teria ocorrido no quadro das chamadas guerras sertorianas e levado à sublevação das tribos do noroeste, mas desta vez sem uma referência específica à ajuda dos gaditanos. É possível que, também aqui, estes tenham participado no processo de conquista, pelo menos no apoio logístico da frota naval para o transporte de provisões e equipamentos ${ }^{10}$.

Pouco tempo depois, em 60 a. C., será a vez de Júlio César. Segundo Dião Cássio, César não se contentou em alcançar a linha do Douro, mas, perseguindo os que tinham fugido, entrou em território galaico. Desta vez o apoio gaditano é inequívoco: para este empreendimento César pede expressamente auxílio a L. Cornélio Balbo, que se tornará um dos seus maiores aliados. O derradeiro encontro entre os dois teria ocorrido em 68 a. C., aquando da primeira visita de César à Península, na qualidade de procônsul da Hispania Ulterior. Depreende-se das palavras de Plutarco ${ }^{11}$, que este teria desembarcado em Córdoba em data próxima ao dia 15 de maio de 61 a. C., depois de uma longa viagem desde Roma, seguindo a rota continental. A partir daí César começa a preparar as suas tropas e, por volta de 10 de junho, ou talvez um pouco antes, parte com as suas legiões para a Lusitânia. Mas, não se conformando com a repressão do banditismo nesta região, provocou uma guerra, estendendo-a, como acima referimos, a norte do Douro. Esta campanha, arriscada, serviu para cumprir os desejos de César: as legiões proclamam-no imperator, reforçando assim os laços de clientelismo militar. Os numerosos despojos de guerra cobrados foram generosamente repartidos pelos soldados, sem se esquecer de reservar para si uma parte para restaurar as suas finanças e enviar ao erário público de Roma avultadas somas como modo de justificar a guerra empreendida ${ }^{12}$. Esta expedição a norte do Douro indica-nos, uma vez mais, que o rio era considerado como uma linha de fronteira. Mas esta delimitação do Douro como linha de fronteira também nos é sugerida pelo chamado «Bronze de Bembibre», um documento redigido meio século mais tarde, no ano 15 a. C., apenas terminadas as guerras contra Cântabros e Ástures.

\footnotetext{
${ }^{8}$ TOVAR, 1975: 80-81; TRANOY, 1981: 130.

${ }^{9}$ MARTÍNEZ MERA, 2001: 307.

${ }^{10}$ MORAIS, 2007a: 103.

${ }^{11}$ Caes., 11,3 e ss; FERREIRO LOPEZ, 1988: 363.

${ }^{12}$ MORAIS, 2007a: 104.
} 
Neste bronze menciona-se uma provincia, a Transduriana, que independentemente do seu significado considera o Douro como um limite.

Para além dos dados alusivos ao processo de conquista, conhecem-se outras fontes literárias, ainda que muito parcas, sobre a navegabilidade do rio Douro, assunto que nos iremos debruçar mais adiante.

A referência a Cale ocorre no Itinerário de Antonino como plataforma viária entre Langobrica e Bracara Augusta. Voltamos a encontrar referências literárias sobre esta região em época tardia, na Crónica de Idácio e no Código Visigótico (ou Liber Iudiciomum), mencionando-se neste último caso a cultura da vinha no Douro.

A continuidade das tradições vinhateiras no Douro está, todavia, bem presente nos documentos medievais. Os Forais, as Inquirições e as Cartas Régias referem para este território a existência de pesqueiras, de barcas de passagem, do transporte de produtos pelo rio, de portagens e outros tributos pagos pelas embarcações e dos conflitos sobre os direitos e privilégios de concelhos e senhores ${ }^{13}$. Nos capítulos especiais das Cortes de Leiria celebradas em 1254 sabemos que no tempo daquele monarca os barcos que desciam o Douro até ao Porto eram muito numerosos e vinham carregados de «vinho, madeira e outras cousas»"

Este é também o tempo da fixação das comunidades religiosas, com destaque para os mosteiros da Ordem de Cister, nomeadamente S. João de Tarouca, Santa Maria de Salzedas e S. Pedro das Águias, que, embora se localizassem nos limites ou fora da região produtora de vinhos de qualidade, fizeram grandes investimentos no cultivo da vinha, fundando várias quintas, algumas das quais ainda hoje existentes. E já nos finais da Idade Média o infante D. Henrique ordenou a construção de setenta embarcações que levaram os portugueses a Ceuta, iniciando assim a gesta dos descobrimentos. Mais tarde, quando o império português começava a ganhar forma, muitas das naus utilizadas nas viagens à Índia por Vasco da Gama, Paulo da Gama e Honório Coelho, foram construídas no arsenal da Ribeira do Ouro (Lordelo do Ouro, Porto $)^{15}$. Estava assim traçado o papel do rio Douro como plataforma viária e acentuava-se a sua importância nos circuitos de comércio atlântico.

\section{AS CONDIÇÕES DA NAVEGABILIDADE}

O Douro, Durius para os romanos, é o terceiro rio mais extenso da Península percorrendo cerca de $927 \mathrm{~km}$ desde a nascente, na Serra de Urbión (Cordilheira Ibérica), a uma altitude de cerca de 1.700 metros, até atingir a foz na costa atlântica. Na parte portuguesa o rio corre na direção E-W num total de cerca de $213 \mathrm{~km}$. Possui a maior bacia hidrográfica da Península, com uma área de cerca de 97, 603 mil km2,

\footnotetext{
${ }^{13}$ PEREIRA \& BARROS, 2001: 63.

${ }^{14}$ CARDOSO, 2012: 239.

${ }^{15}$ CARDOSO, 2012: 238.
} 
correspondendo a $17 \%$ da sua superfície total. A parte correspondente ao atual território português abrange cerca de $18,643 \mathrm{mil} \mathrm{km}^{2}$, aproximadamente um quarto da superfície do território nacional ${ }^{16}$.

São certamente as características naturais acima descritas que levaram Estrabão (III 3.4) a referir que o Douro era navegável por grandes navios em cerca de 800 estádios (aproximadamente $161 \mathrm{~km}$ ), encontrando-se o primeiro ponto fixo de navegação na cidade indígena de Acontia, «...pertencente aos Vaqueus», segundo as palavras do mesmo (III, 2.3). Este limite corresponde a Barca d'Alva, nas proximidades da atual fronteira entre Portugal e Espanha. Segundo Apiano (Ibér. 91), o restante percurso era realizado a partir de barcas movidas a remo, ajudadas por velas. Efetivamente, a partir daqui, o rio seguindo o seu percurso internacional até Zamora, afunda-se nas suas gargantas, para depois se espraiar ao longo de quilómetros nas planuras da Meseta.

Na parte portuguesa, o rio Douro corre, como mencionámos, num vale mais aberto, ora ladeado por granitos, ora por xistos, e apresenta um declive menos acentuado, cerca de $0,6 \mathrm{~m}$ por $\mathrm{km}^{17}$. O perfil longitudinal entre Freixo de Espada à Cinta e Peso da Régua, não é acentuado, ainda que alguns dos seus afluentes apresentem perfis declivosos, alguns dos quais ainda em fase de erosão vertical vigorosa e visível.

Da zona de fronteira até à sua foz o rio usufrui de uma rede complexa de pequenas linhas de água, ribeiras, subafluentes e afluentes que drenam as águas até ao seu leito. Nestes cabe destacar o papel dos principais afluentes: na margem direita, os rios Sabor, Tua, Pinhão, Corgo, Teixeira, Tâmega e Sousa, e na margem esquerda, para além do rio Águeda, Aguiar, Côa, Teja, Torto, Távora, Tedo, Varosa, Cabrum, Bestança, Paiva e Arda ${ }^{18}$. Estes afluentes têm uma grande oscilação do nível das águas, apresentando um fraco caudal durante o verão e cheias frequentes no inverno. Deste modo, apresenta um leito acidentado e um regime bastante irregular, com uma acentuada estiagem e fortes chuvas no inverno, que provocavam, antes da construção das barragens, fortes cheias ocasionais. De acordo com os registos conhecidos a maior cheia dos últimos séculos teria ocorrido nos dias 3, 4 e 5 de dezembro de 1739, com uma força de corrente de $16 / 17$ milhas, um caudal de $300.000 \mathrm{~m}^{3}$, tendo subido 6 m o coroamento do cais da Ribeira. Seguem-se, por ordem de grandeza, as de 23 e 24 de dezembro de 1909, com uma corrente de 16 milhas de velocidade, com uma altura de 5,16 m relativamente ao cais da Ribeira; a última grande cheia ocorreu em $1978^{19}$. Quando comparado com os outros rios europeus o rio Douro destacava-se, efetivamente, pelas suas cheias. Poucos são os rios além Pirenéus - com exceção

\footnotetext{
${ }^{16}$ CORTES, 2008: 201; BARBOSA, 2008: 117.

${ }^{17}$ CORTES, 2008: 202.

${ }^{18}$ BARBOSA, 2008: 318.

${ }^{19}$ COUTINHO \& BARROTE, 1986: 18.
} 
feitas aos das estepes russas - cujas cheias possam atingir os $20.000 \mathrm{~m}^{3}$, como já ocorreu no Douro ${ }^{20}$.

Sabemos pelas fontes literárias (Tito Lívio, Dião Cássio, Tácito, Plínio-o-Velho, autores da Historia Augusta, entre outros) que o que mais preocupava os antigos romanos na sua relação com os rios eram as cheias ocasionais (aquae ingentes) ${ }^{21}$. No caso do rio Douro os deuses deveriam castigar periodicamente os locais ribeirinhos e, a julgar pelos dados históricos antes da construção das barragens, as cheias podiam ser verdadeiramente destrutivas. Não obstante, sabemos que os romanos encaravam as cheias com um reverente fatalismo, como uma mensagem ou uma advertência dos deuses. Conhecida é a intenção de Júlio César que tinha entre os seus projetos urbanísticos o plano de desviar o caudal do rio Tibre, precisamente para evitar as cheias periódicas.

Uma maneira de acautelar ou menorizar os prejuízos de uma cheia seria cuidar das margens evitando a acumulação de sedimentos e detritos, a par do restauro de pontes e molhes e de outras zonas de atracagem. Conhecem-se para o rio Tibre os curatores alvei Tiberis et riparum, uma corporação responsável por essas operações ${ }^{22}$; não sabemos se existia no Douro uma corporação com os mesmos fins, mas é possível. O interesse de Roma em manter navegáveis os cursos de água está documentado nas disposições legais compiladas no capítulo XV do livro XLIII do Digesto ${ }^{23}$.

São pois estas as condições que fazem com que o rio Douro seja conhecido como difícil de navegar. Os dados etnográficos permitem supor que a navegação no Douro na antiguidade fosse uma aventura devendo acautelar-se os rochedos, os secos e as areias, alternadas, a cada passo, por poços, locais de águas paradas que impediam a normal progressão das embarcações ${ }^{24}$. A viagem da foz até Barca d’Alva e em sentido inverso seria certamente difícil. Devemos assim pensar que a navegação se fizesse através de percursos fragmentados, sectoriais, recorrendo-se a embarcações de diferente calado, complementados por caminhos terrestes ao longo das suas margens.

Ocasionalmente seria necessário vencer os rápidos e içar as embarcações com a força dos braços dos sirgadores (herciarii) ou com a ajuda de animais de tiro, a partir de areais e caminhos abertos nas penedias, apertados e difíceis. Esta técnica de alagem, ou sirga, deve ter sido frequente, sobretudo nos meses estivos. Este sistema de tração exigia a existência de caminhos de sirga apropriados (pedestro iter) ${ }^{25}$, por norma controlados pelas cidades ${ }^{26}$. Sabemos, pelo menos para o século XX, que as alagens com

\footnotetext{
${ }^{20}$ SILVA, 1986: 37.

${ }^{21}$ SIERRA DE CÓZAR, 2008: 99.

22 SIERRA DE CÓZAR, 2008: 104.

${ }^{23}$ CHIC GARCÍA, 1978; ESCACENA CARRASCO \& PADILLA MONGE, 1992: 73.

${ }^{24}$ CARDOSO, 2012: 241.

${ }^{25}$ CHIC GARCÍA, 1984: 37.

${ }^{26}$ ORDÓNEZ AGULLA, 2003: 63.
} 
bovinos se faziam no Douro já a partir dos areais de Gondomar/Castelo de Paiva ${ }^{27}$. Manuel Monteiro na sua emblemática obra intitulada O Douro dá-nos este testemunho:

Subir, porém, é uma faina ingratissima para a maruja. Se o vento sopra favoravel, iça-se a verga - a antenna, com a véla, e os remos ajudam a sua força motriz. Todavia póde isto não ser bastante para vencer a marcha arrebatada $e$ violenta das vagas, e, então, os marinheiros desembarcam, e puxam á sirga, alando, pouco a pouco, ao longo d'um caminho de cabras trilhado na riba pedregosa, o rabello que parece negar-se a avançar ao arrepio das aguas que o rechassam. Quando estas são volumosas e é demais a sua furia, alija-se parte da carga, se é possivel, transportando-a a maruja para montante do cachão e os bois sirgam o barco. No Douro Illustrado do V. de Villa Maior conta-se esta operação: "O barco fica ás vezes vasio até ao sagre. Solta-se então de bordo para terra um cabo, que vae prender em volta de um penedo, ou n'um buraco feito á broca, e d'ahi vem passar por uma roldana móvel pendente do lado da prôa, indo a outra extremidade atar-se no jugo ou canga de uma junta de bois, que pela margem o vae puxando. Se o barco é um pouco mais pesado, são duas as roldanas e outros tantos os cabos, ou tambem o cabo depois de prender ao primeiro jugo vae ainda adiante prender ao segundo. Mas é ás vezes tal a resistencia da corrente, sobretudo quando em rio alto se não tem trasfegado a carga, que ou os cabos estalam, ou os boieiros os cortam, porque o barco leva de rojo os possantes animaes.

Ora, se fôr preciso desjungir os bois, cumpre atar a sirga, a toda a brida, em volta da rocha por cujo orificio passa, afim de procurar suster a embarcação, porque do contrario, ou se a corda rebenta, o sinistro é fatal. Só um acaso feliz póde salvar a nave, que, sem o governo da espadela, é arrebatada de rostilhão, á mercê das ondas, para o naufragio! ${ }^{28}$

Apesar do perigo que estas viagens representavam o transporte de mercadorias em época romana far-se-ia seguramente através do canal fluvial dado que o transporte terrestre seria altamente oneroso: basta recordar que o transporte por terra custava, em média, por cada milha, onze vezes mais que por via fluvial. Quando o percurso terrestre era inevitável o transporte de mercadorias seria provavelmente feito através de carros de bois, os plaustra, bem adaptados aos declives do território duriense.

Mas não devemos pensar num uso meramente destinado ao transporte de mercadorias, pois certamente o canal fluvial teria sido usado para o trânsito de pessoas e animais. Este uso teria exigido, para além das infraestruturas de apoio à navegação e de

\footnotetext{
${ }^{27}$ SOEIRO, 2006: 406.

${ }^{28}$ MONTEIRO, 1998. 143.
} 
estaleiros especializados na construção de algumas embarcações, a existência de locais para controlo administrativo e fiscal, como se conhecem para outras regiões do império.

Um dos principais obstáculos à navegabilidade eram os chamados "pontos», locais de onde a passagem das embarcações era dificultada pelos açudes de maior ou menor dimensão. Como se sabe, estes locais são propensos à existência dos já mencionados «poços» ${ }^{29}$. De todos os contratempos acima referidos acerca da navegabilidade do rio há um que inequivocamente representou um obstáculo intransponível, pelo menos até os finais do século XVIII: o famoso Cachão da Valeira, situado a montante da foz do rio Tua e a cerca de $6 \mathrm{Km}$ deste. Este local era atravessado por um fragão granítico onde as águas represadas formavam grande cachoeira, impedindo a navegação a montante ${ }^{30}$. Voltamos, mais uma vez, às palavras de Manuel Monteiro ${ }^{31}$ que nos deixa o seguinte testemunho:

O vertice reintrante do angulo que o Douro aqui fórma e onde está o ponto do Cachão approxima-se: d'além a verticalidade irregular e sinistra prolonga-se e sóbe indefinidamente para os ápices em que se encarrapita S. Salvador do Mundo; d'aquem dá-se um imprevisto desvio na linha de projecção e os penhascos tisnados e pardos apparecem ladeirentos e resvaladiços; no fundo, a corrente inesperadamente ganha movimento, anima-se, accelera-se, e, dobrada a curva, precipita-se, esbravejante, no ponto, cachoando turbilhonando, refervendo... e ondas rendadas de escuma correm, violentamente impellidas, rosnando a sua dolorida canção.

A luz vinda da tira anilada de céu põe effeitos extranhos neste scenario phantastico que parece ter inspirado algumas das paginas com que o genio de Gustave Doré illustrou o Inferno de Dante.

No Esbôç̧o Litológico da Região Duriense o engenheiro Luís Azeredo de Sá Fernandes refere que na primeira delimitação da região demarcada do Douro feita no tempo do Marquês de Pombal, não se incluíram os concelhos a montante do Cachão da Valeira, porquanto o rio Douro era a única via de comunicação. Com a destruição dos rochedos e o posterior alargamento do rio no tempo de D. Maria I, a partir de 1780, as embarcações começaram a subir o rio alargando-se paulatinamente a região demarcada que passa a incluir todo o vale do Douro desde a povoação de Barqueiros até à Barca-de-Alva na fronteira e a povoação de Mazouco no concelho de Freixo-de-Espada à Cinta, ainda na margem direita do Douro, e os vales dos rios dos seus afluentes ${ }^{32}$.

\footnotetext{
${ }^{29}$ CARDOSO, 2012: 241.

${ }^{30}$ A demolição deste obstáculo natural foi encomendada pela Companhia Geral da Agricultura das Vinhas do Alto Douro, e decorreu entre 1780 e 1792 (LOPES, 2008: 277).

${ }^{31}$ MONTEIRO, 1998: 94.

${ }^{32}$ FERNANDES, 1944: 18.
} 
Um outro aspeto a considerar-se na navegabilidade do Douro é a sua importante função como enclave portuário na chamada rota atlântica. À semelhança dos testemunhos conhecidos para a Gália ${ }^{33}$ é possível que os barcos vindos do oceano penetrassem ao longo do rio e aportassem nos seus ancoradouros, aproveitando as reentrâncias e saliências das suas margens para cargas e descargas. Mas antes destas manobras as embarcações teriam de vencer as dificuldades da barra, com os seus bancos de areia sujeitos a constantes alterações morfológicas que fechavam ocasionalmente a foz, e bordear o espaço liberto dos escolhos graníticos submersos que constituíam sérios obstáculos à sua passagem. Estes escolhos, para além do perigo de embate, afunilavam o canal de navegação e retiravam a profundidade do rio com as oscilações da maré. Alguns destes escolhos, cerca de duas dezenas, ainda são visíveis na gravura de T. Maldonaldo, inserta na Descrição Topográfica e História da Cidade do Porto, de Agostinho Rebelo da Costa. O perigo aumentava durante as cheias ocasionais ou em dias de maresia ou nevoeiro, impedindo muitas vezes a navegação. Estas dificuldades da barra teriam certamente provocado um número elevado de naufrágios, de recusas de acesso e de passagens ao largo. Noutros casos podia ter-se recorrido a soluções mais simples, limitando-se as embarcações a pairar ao largo ou varando nas praias da proximidade da barra, quando de mais reduzido porte. A entrada segura das embarcações na barra conduzi-las-ia aos ancoradouros provavelmente situados em ambas as margens que facilitavam a ligação entre a água e a terra, tornando possível saltar da e para a margem e descarregar ou carregar os produtos de comércio. São ainda passíveis de terem sido utilizados outros processos mais precários de descarga e carga de produtos através da utilização e simples pranchas que ligavam as embarcações aos cais de acostagem.

As dificuldades da entrada na barra foram sendo colmatadas com alguns trabalhos de engenharia. Chegou-se a pensar na abertura de um canal interior, ligando o Douro à ria de Aveiro, intersectando a Barrinha de Esmoriz. Este projeto desenhado por um engenheiro chamado Isidoro Paulo Pereira, não foi concretizado. Esta ideia foi mais tarde, em 1835, retomada pela Associação Mercantil da Cidade do Porto, mas mais uma vez sem concretização ${ }^{34}$.

Mas, como havíamos sugerido ${ }^{35}$, para além destes sítios de ancoragem situados junto à foz do rio, deveríamos ainda considerar a possibilidade de outros locais nas suas proximidades, a montante, terem funcionado como fundeadouros na antiguidade.

Esta sugestão foi entretanto comprovada nas várias campanhas de escavação iniciadas em 2010 no lugar do Castelo de Crestuma, situado na margem sul do rio, a jusante da barragem, e que permitiram corroborar o interesse arqueológico do sítio

\footnotetext{
${ }^{33}$ IZARRA, 1993: 174-175.

${ }^{34}$ AMORIM, 1986: 17.

${ }^{35}$ MORAIS, 2005: 55.
} 
já referido em meados do século passado por Arlindo de Sousa e, mais tarde, por Carlos Alberto Ferreira de Almeida. Embora estes autores não tenham identificado o local como cais romano, referia-se, o primeiro, à possível existência de um castro romanizado e, o segundo, a uma fortificação medieval com antecedentes tardo-romanos. As campanhas que têm vindo a ser realizadas junto à margem revelaram a existência de um local de carga e descarga de produtos em época romana e tardo-antiga $^{36}$. A referência mais recuada a este local encontra-se num documento medieval do século XII que o situa em locum castrumiae, no sítio onde o rio Uima desemboca no Douro ${ }^{37}$. Os estudos realizados pelos diretores de escavação têm revelado a presença de distintos materiais datados desde a Idade do Ferro até ao período medieval, com destaque para as produções tardo antigas de origem norte africana e oriental, representadas por cerâmicas finas e ânforas.

Considerando as condições de navegabilidade do rio Douro e o seu caudal ao largo dos meses do ano, é possível que as embarcações de maior tonelagem de transporte marítimo-fluvial pudessem ter circulado até a altura de Crestuma, mas muito dificilmente ultrapassariam a zona de Entre-os-Rios.

As embarcações seriam certamente variáveis, consoante os fins a que destinavam, quer na dimensão, quer na forma do casco. À semelhança dos dados etnográficos conhecidos, quando o declive do leito do rio se apresentasse mais acentuado e, consequentemente, a corrente fosse mais forte e agitada, tinha-se que recorrer ao referido método da sirga de modo as vencer as correntes. No sentido inverso, durante a descida, as embarcações podiam contar com a corrente favorável do rio, embora essas mesmas correntes representassem um grande perigo e fossem difíceis de manobrar.

A partir daqui a circulação a montante do rio seria provavelmente feita com recurso a embarcações exclusivamente fluviais (naves fluminales), podendo a carga transportada ser dividida em pequenos barcos movidos a remos, ajudados por velas ${ }^{38}$, e pirogas de fundo chato. De acordo com as fontes escritas e os monumentos epigráficos e outro tipo de suportes (mosaicos, relevos, entre outros), sabemos que este tipo de embarcações, embora conhecidas pela sua precaridade, intermitência e lentidão, foram largamente usadas no mundo romano.

No rio Douro é possível que estas embarcações pudessem corresponder a grandes barcaças fluviais de fraco calado. Apesar de estas poderem ser de diversos tipos, segundo a sua função e o curso do rio em que eram utilizadas, quase todas se moviam a remos, ainda que por vezes possuíssem uma pequena vela para ajudar os remadores $^{39}$. A documentação medieval refere-nos a existência deste tipo de barcaças

\footnotetext{
${ }^{36}$ GUIMARÃES \& GUIMARÃES, 2001: 43-47; SILVA \& GUIMARÃES, 2013a; SILVA \& GUIMARÃES, 2013 b: $883-893$.

${ }^{37}$ SILVA \& GUIMARÃES, 2013a; 2013b: 883-893.

${ }^{38}$ Apiano, Ibér. 91.

${ }^{39}$ IZARRA, 1993: 38.
} 
no Douro. Num documento datado de 1336, alusivo a um conflito de jurisdição entre os moradores de Castelo de Paiva e os de Entre-os-Rios, diz-se que estas podiam transportar vinho em "pipas de tres bolhas» ${ }^{40}$. É possível que este tipo de barcaça, mais tarde designada pelo nome de "azurracha», fosse aquela usada no transporte fluvial, antes da afirmação dos barcos rabelos. Manuel Pereira de Novaes, no segundo quartel do século XVI, descreve-a da seguinte forma ${ }^{41}$ :

...navegasse el rio con grandes barcas, algunas de màs de 30 toneladas que sin [sic.] tener de carga màs de sessenta pipas de paria, de capacidad de 12 almudes de vino cada... y suelen baxar por el rio muchas dellas cada dia, que es una prodigiosa riqueza, todo lo qual se entiende desde el espacio de donde se navega, que son... veinte y cinco leguas, desde San Iuan de la Pesquera hasta nuestra ciudad.

Estas barcaças possuíam uma única vela, latina, sendo necessário manobrá-la a remos sobretudo em locais pouco profundos. Em meados do século XVI este tipo de embarcações subia e descia o rio com cerca de 30 pipas ou 1500 alqueires, podendo alcançar as 25 toneladas e, talvez, alguns destes passassem a barra do Douro carregadas de vinhos para comercializar noutras paragens ${ }^{42}$.

Não podemos ainda descartar a possibilidade de terem sido usadas simples balsas fabricadas mediante a união de troncos com cordas ou $\operatorname{cravos}^{43}$ para o transporte de produtos. Estas embarcações, conhecidas entre os romanos como rates silve rataria, manobravam-se com a ajuda de um remo ou mesmo de uma pequena vela, em função do seu tamanho e curso do rio onde se encontrassem, mas também serviam da barcaça e para auxiliar o embarque e desembarque de mercadorias a partir de embarcações maiores ${ }^{44}$. Conhecem-se para o Douro referências quinhentistas de embarcações, conhecidas por almadias, que parecem possuir algumas afinidades com aquelas de época romana. Num dos raros documentos conhecidos sobre este tipo de embarcações refere-se que:

Desde Sam Joam da Pesqueira tambem vem ao porto almadias feitas de cortiça, que trazem cem duzias de cortiça, e mais, liadas com páaos, e esta cortiça se vende a pescadores pera boias, e a çapateiros; e sobre ella trazem muitos odres de vinho, e vinagre, e mel, e muitos sacos de çumagre; e vem homens nellas que as governam; sam mais seguras de perigo que as barcas $^{45}$.

\footnotetext{
${ }^{40}$ DUARTE \& BARROS, 1997: 110.

${ }^{41}$ SOEIRO, 2006: 402.

${ }^{42}$ DUARTE \& BARROS, 1997: 110.

${ }^{43}$ CHIC GARCÍA, 1984: 35.

${ }^{44}$ PARODI ÁLVAREZ, 2001: 32.

${ }^{45}$ DUARTE \& BARROS, 1997: 111.
} 


\section{A ROMANIZAÇÃO DE UM TERRITÓRIO INTERIOR}

Após as sucessivas campanhas de conquista iniciadas no decorrer do século II a. C., os romanos foram-se impondo no decorrer do período imperial no território abrangido pela bacia do Douro. Graças a um processo de miscigenação foram-se abandonando alguns castros e romanizaram-se outros, ocupando-se áreas de vale, fomentando-se a cultura da vinha e dos cereais e dando início a uma exploração mais sistemática das minas. A presença romana veio, neste sentido, redefinir a ocupação do território e da sua economia. Neste processo construíram-se estradas e pontes e criaram-se novas infraestruturas relacionadas com o aproveitamento das águas. Não surpreende, assim, a existência de estações termais junto a alguns povoados adjacentes ao rio, como é o caso de Entre-os-Rios, Caldas de Vizela, Caldas de Aregos, Caldas de Moledo, Cambres, Vilariça, Longroiva, e, em particular, a cidade de Aquae Flaviae (Chaves) ${ }^{46}$. Noutros casos, ainda, dá-se um verdadeiro sincretismo cultural, fundindo-se os cultos religiosos indígenas com os romanos, incluindo aqueles orientais, bem evidente no santuário de Panóias, onde se documentam altares de sacrifícios cavados nas rochas a par de inscrições em latim e grego.

A presença romana na região está naturalmente associada à produção vitivinícola. Os antecedentes pré-romanos que documentam a existência de vinhas na região são conhecidos, como se comprova pelo achado de grainhas de vitis vinífera encontradas em estratos do III milénio no Buraco da Pala (concelho de Mirandela) e do Io milénio no Castro de Penices (Vila Nova de Famalicão) ${ }^{47}$. Em época romana as estruturas associadas ao fabrico do vinho são testemunho inequívoco dessa atividade, nalguns casos com fins nitidamente comerciais.

No estudo de João Viana Antunes e Pedro Baère de Faria, apresentado como um dos capítulos da série História do Douro, apresenta-se uma síntese da ocupação da região do Alto Douro, especialmente para os períodos da Idade do Ferro e Época Romana, abarcando os concelhos de Lamego, Tarouca, Armamar, Moimenta da Beira, Tabuaço / S. João da Pesqueira, Meda, Vila Nova de Foz Côa, Figueira de Castelo Rodrigo, Freixo de Espada à Cinta, Torre de Moncorvo, Alfândega da Fé, Vila Flor, Carrazeda de Anciães, Murça, Alijó e de Sabrosa a Mesão Fio ${ }^{48}$. As inúmeras estações arqueológicas aí referenciadas são demonstrativas de uma grande diversidade de ocupação de carácter agrário em época romana, interpretadas como villae, casais, vicus, mansiones ou mutationes, com funções necessariamente distintas.

Neste território têm vindo a ser identificados inúmeros lagares e lagaretas (torcularia) bem como áreas de adegas (apothecae) e de armazenamento de vinho, como referimos, testemunhos inequívocos da importância vitivinícola da região em época

\footnotetext{
${ }^{46}$ DIAS, 2006: 309; BARROS \& PEREIRA, 2008: 21.

${ }^{47}$ ALMEIDA, 1996: 22; ALMEIDA, 2006: 373.

${ }^{48}$ ANTUNES \& FARIA, 2006: 211-281.
} 
imperial. Este seria o caso de algumas villae com instalações vinárias como Fonte do Milho (Peso da Régua), Quinta do Noval (Alijó), Olival de Telhões (Almendra, Vila Nova de Foz Côa), Azinheira (Carlão, Alijó), Rumansil I e Zimbro II, entre muitas outras ${ }^{49}$.

Como noutros territórios do império, as villae representavam a unidade básica da agricultura nesta região, um meio de rentabilidade económica importante, pelo menos no que diz respeito à produção vitivinícola. A importância desta atividade pode ser comprovada pela existência de villae onde se registou o fabrico de dolia, como Fornelos (Louredo, Santa Maria de Penaguião) e Rumansil I (Numão) ${ }^{50}$.

A importância do fabrico de dolia no mundo romano está bem patente no livro XXXV da História Natural de Plínio o Antigo (35.159-165). Nesta obra o Naturalista refere que maior pars hominum terrenis utitur vasis («na sua maioria, a humanidade utiliza vasos de terracota»). Este enunciado (35.160) enquadra-se num longo trecho sobre os produtos oferecidos pela benignidade da terra, em especial a obra dos oleiros (33.159: figlinarum opera). Plínio refere vasos em argila (vas, 'vaso'), ou fictilia, que satisfazem plenamente as necessidades (vel adsiduitate satiant figlinarum opera), indicando, logo de início, diferentes usos, desde contentores de vinho (doliis ad vina) e de azeite (olearia) a urnas funerárias (fictilibus soliis), ainda que a sua inclusão num grupo não exclua outras funções $(35.159-160)^{51}$.

Num estudo apresentado em conjunto com Pedro Pereira, intitulado Estudo crono-tipológico de Dolia romanos em Portugal ${ }^{52}$, apresentámos uma breve análise desta problemática, incindido, em particular, na região do Vale do Douro. Neste estudo destacámos a referida villa romana de Rumansil I, situada num patamar sobranceiro à ribeira de Murça. As escavações aí realizadas puseram a descoberto uma villa tardia, datada dos séculos III a. C., estruturalmente dividida em três grandes áreas construídas: a noroeste um edifício quadrangular, provavelmente associado a atividades metalúrgicas e de habitat; a sudoeste, duas estruturas circulares, de dimensões distintas e um espaço subretangular correspondente a uma oficina destinada ao fabrico de dolia; a sudoeste, um edifício retangular com várias divisões, muito provavelmente destinado a armazém, onde se localizavam as cellae vinárias e o lagar de vinho. Ainda em Freixo de Numão, a identificação de dolia com a marca $L F$ encontradas nas villae rústicas de Zimbro II e Prazo, situadas a cerca de $5 \mathrm{~km}$ de distância uma da outra, parece indicar que estes contentores foram comercializados vazios a pequena e média distância ${ }^{53}$. Se a estas marcas adicionarmos uma outra encontrada

\footnotetext{
${ }^{49}$ ALMEIDA, 2006: 374.

${ }^{50}$ BARROS \& PEREIRA, 2008: 22.

${ }^{51}$ OLIVEIRA, 2014: 15-34.

52 PEREIRA \& MORAIS, 2016: 33-44.

${ }^{53}$ COIXÃO et al., 2005; PEREIRA \& MORAIS, 2016: 42.
} 
no Alto da Fonte do Milho (Peso da Régua) talvez se possa pensar numa verdadeira economia de escala na região.

Na mesma série História do Douro, Lino Augusto apresenta, no capítulo VII, uma outra síntese sobre a região duriense entre a Serra do Marão e o Atlântico, constatando-se, também aí, uma forte ocupação da Idade do Ferro à época romana ${ }^{54}$. Neste território, maiormente controlado pela cidade romana de Tongobriga, conhecem-se numerosos núcleos com função fundamentalmente agrária, como é o caso das villae de Vilarinho e Urrô, próximas desta cidade, e de Sendim, em Felgueiras.

Recentemente, António Sá Coixão, na sua tese de doutoramento intitulada A romanização do Baixo-Côa, atualizou a panorâmica sobre a ocupação proto-histórica, romana e altimedieval nos concelhos de Vila Nova de Foz Côa, Mêda, Figueira de Castelo Rodrigo e Pinhel, embora replicando muitos dos conhecimentos já publicados. De entre as inúmeras referências à ocupação romana, salienta-se, de novo, as dezenas de lagares e lagaretas escavadas nos afloramentos graníticos, em particular nos concelhos de Vila Nova de Foz Côa e Mêda ${ }^{55}$. Se estes testemunhos são, como já referimos, importantes indicadores da importância vitivinícola da região, outros achados permitem corroborar estes dados. Este é o caso do mosaico com a representação de Baco encontrado na villa da Coriscada, em Vale do Mouro, concelho de Mêda ${ }^{56}$.

Embora se constate que a vitivinicultura tenha tido um peso importante na economia da região, outras atividades reforçavam o seu carácter autárcico, nomeadamente o cultivo de cereais e a criação de animais, bem como a produção de têxteis e a exploração de minérios, em particular o ferro. A estas atividades devemos ainda acrescentar a pesca, que certamente complementava os recursos económicos proporcionados. A propósito temos um interessante testemunho do que parece ser um pequeno centro de transformação de pescado na villa rústica de Zimbro II, em Freixo de Numão. No contexto das estruturas baixo-imperiais foram detetados quatro pequenos tanques com opus signinum, dois dos quais provavelmente associados à produção de conservas de peixe de água doce. Segundo Sá Coixão, foi recolhido num interior de um dos tanques conchas de moluscos, provavelmente ameijoas de rio $^{57}$. Ainda segundo o mesmo autor, é de notar que até à retenção das águas do Douro pelas barragens, ainda se pescava o solho ou esturjão, um peixe que chegava a pesar 80 a 90 quilos $^{58}$.

Um dos monumentos mais emblemáticos de toda esta região é a chamada Torre de Almofala, em Figueira de Castelo Rodrigo, localizada no alto de uma elevação de

\footnotetext{
${ }^{54}$ DIAS, 2006: 285-331.

${ }^{55}$ COIXÃO, 2017: 148; 154-158; 161-162, figs. 40-42.

${ }^{56}$ COIXÃO, 2017: 116-118; 217-221, fig. 63.

${ }^{57}$ COIXÃO, 2017: 98.

${ }^{58}$ COIXÃO, 2017: 98.
} 
perfil suave. As estruturas, bem conservadas, correspondem ao podium de um templo que ainda mantém paredes com uma altura média de 2,65 metros, integralmente construídas com silhares de granito. A razão deste excecional estado de conservação deve-se ao facto das estruturas terem sido aproveitadas como atalaia de vigia nos períodos medieval e moderno. As escavações realizadas em 1997 no interior do recinto permitiram encontrar uma pequena ara datada dos inícios do século I dedicada a Júpiter Óptimo Máximo ${ }^{59}$. Graças a esta ficámos a saber que estamos perante a civitas dos Cobelcos que controlavam um vasto território, muito provavelmente delimitado a norte, pelo rio Douro, a nascente, pelo rio Águeda, a poente, pelo rio Côa e a sul pela Serra da Marofa ${ }^{60}$.

Os vestígios arqueológicos têm revelado uma continuidade na ocupação de todo este território duriense em época tardo-romana e suevo-visigótica, continuidade essa que também se faria sentir no aproveitamento das possibilidades económicas na exploração do rio e da sua navegabilidade. $\mathrm{O}$ paroquial suevo indica a organização administrativa destas terras, tendo Lamego sido instituída como sede de bispado e cunhado moeda, trientes, no tempo do rei visigodo, Sisebuto (612-621). Ele e os seus sucessores alargaram, de resto, essa atividade, criando oficinas em Caliábria, uma sede de bispado ainda por identificar com segurança ${ }^{61}$.

A história da região duriense irá afirmar-se nos séculos seguintes, mas estes antecedentes estão seguramente na génese deste ímpar património da humanidade.

\section{DOIS IMPORTANTES NÚCLEOS NA DESEMBOCADURA DO RIO}

Este breve excurso sobre o rio Douro e respetiva região ficaria incompleto sem uma referência aos dois grandes núcleos populacionais situados na sua desembocadura: na margem esquerda, um enclave marítimo de cujo nome desconhecemos (atual cidade de Vila Nova de Gaia), e na margem direita Cale, que muito provavelmente surge a partir do povoado castrejo romanizado situado no morro granítico da Penaventosa. Armando Coelho e Vasco Mantas sustentaram, com argumentos convincentes, a identificação de Cale com o Porto ${ }^{62}$. Nos finais do século VI, no Parochiale suévico o nome da cidade aparece como sede de bispado sob a forma Portugale (Ad sedem Portugalensem in castro novo ecclesias que in vicino sunt) ${ }^{63}$.

Podemos perguntar-nos se a ausência de estruturas portuárias de época romana é indicador de um comércio menos ativo com o exterior. Acreditámos que não. Sabemos que na maior parte dos casos os romanos não construíram grandes instalações

\footnotetext{
${ }^{59}$ FRADE, 1998.

${ }^{60}$ FERNANDES, 2016: 52-59.

${ }^{61}$ BARROS \& PEREIRA, 2008: 24.

62 SILVA, 1994: 68ss; SILVA, 2000, 98-103; MANTAS, 1996: 652-659.

${ }^{63}$ ALARCÃO, 2005: 304-306.
} 
portuárias mas antes aproveitaram as condições naturais de determinada região para o efeito. Outros casos se conhecem em que grandes enclaves portuários apenas possuíam pequenos molhes de pedra ${ }^{64}$.

Mas perante estas interrogações recorremos a uma evidência inequívoca os vestígios epigráficos e os materiais cerâmicos importados de época romana que têm vindo a ser recuperados. De entre eles destaquem-se as estelas funerárias que levaram Alain Tranoy (1995) a sublinhar o papel de comunicação e convergência possibilitado pelo rio. Segundo alguns autores uma ara em granito encontrada fora de contexto num dos alicerces de um templo proto-românico no Castelo de S. João da Foz, pode ser associada às divindades aquáticas (Aquis Magaudiis), estando o seu caracter votivo documentado pela fórmula final, $L$ (ibens) $V$ (otum) $S$ (olvit) ${ }^{65}$. Em estudos mais recentes Armando Redentor questiona a ligação direta ao elemento marinho divinizado, lendo antes a insólita consagração $\mathrm{Ae}($ ternis) (?) $D(i) u(i s)$, com paralelo na ara com turíbulo de prata aparecida em Tongobriga ${ }^{66}$. Apesar de hoje desaparecida, o achado na Igreja de S. Pedro de Miragaia (Porto) de uma ara votiva, hoje desaparecida, com a inscrição [---]? /Duri/C(aius).Iulius/Pylades (CIL II 2370) sugere, segundo Maria Blanca García e F. Albalát ${ }^{67}$ a consagração do rio como uma divindade. Esta possibilidade têm, porém, sido questionada por outros autores. Armando Redentor ${ }^{68}$, com base noutras inscrições leonesas dedicadas a ninfas, sugere poder tratar-se de uma inscrição consagrada às ninfas do flumen Durius. Ainda segundo este autor é sugestiva a hipótese que o dedicante tivesse desempenhado funções ligadas à mineração, talvez como procurator metallorum, representando os interesses dos imperadores na exploração auríferas da área das serras de Santa Justa, Pias e Banjas), em finais do século I. Igualmente interessante é uma árula encontrada nos arredores do Porto ${ }^{69}$. Ainda segundo Redentor ${ }^{70}$, esta epígrafe, com a inscrição I. O. M. Conseruator B(almarcodes) (?), está associada a um culto oriental, concretamente à costa síria, e testemunho de um "claro sincretismo» entre o deus romano e a divindade fenícia Baal Marquod, revelando, uma vez mais o papel de Cale como verdadeiro porto comercial.

Mas, no que à epigrafia diz respeito, devemos estranhar que não se tenham encontrado mais documentos deste tipo? Julgamos que não, pois sabemos que os romanos tinham por norma a dessacralização da água em ambientes fluviais e em

\footnotetext{
${ }^{64}$ ORDÓÑEZ AGULLA, 2003: 65.

${ }^{65}$ OSÓRIO, 1993: 27; OSÓRIO \& SILVA, 1994: 91; SILVA, 2000: 93, 102-103; SILVA, 2010: 233.

${ }^{66}$ REDENTOR, 2011: 272.

${ }^{67}$ BLANCA GARCÍA \& ALBALÁT, 1986: 15.

${ }^{68}$ REDENTOR, 2011: 270-271.

${ }^{69}$ ALMEIDA, 1968: 288-289.

${ }^{70}$ REDENTOR, 2011: 272.
} 
obras de carácter hidráulico para o abastecimento de água, reservando esse culto para âmbitos mais específicos, como as termas, as fontes e as nascentes ${ }^{71}$.

O estudo que realizamos sobre as ânforas do povoado mineiro da Quinta da Ivanta, situado na encosta norte da serra de Santa Justa, entre a ribeira de Valongo e a entrada do Fojo das Pombas, um dos núcleos do couto mineiro da região Mineira do Douro, testemunha o abastecimento de produtos importados por via marítima tendo como via de penetração privilegiado o canal fluvial do Douro ${ }^{72}$. As ânforas, datadas do século I e os inícios da centúria seguinte, estão representadas por mais de seis dezenas de exemplares de proveniência bética e lusitana, com predomínio das primeiras. Como demonstramos, o interesse desta amostra não se fica pelo número destacado das ânforas Haltern 70, como sabemos bem representadas em todo o noroeste, mas pela presença proporcionalmente significativa, das ânforas de azeite Dressel 20, pouco abundantes na região. Entendemos que este fenómeno, atípico na região, se poderia relacionar com um abastecimento de tipo institucional e de cariz anonário aos locais de mineração, com afinidades com outros locais mineiros situados no atual território português, como é o caso de Aljustrel ${ }^{73}$.

Os cerca de dezasseis quilómetros que separam a serra de Santa Justa do Porto são de facto diminutos se pensarmos que os produtos poderiam circular em embarcações de pequeno calado por um dos afluentes do Douro junto à serra de Santa Justa, o rio Sousa; no sentido inverso realizar-se-ia o escoamento dos minérios, em particular ouro, deste importante territorium metallorum controlado pelo Estado. Como ocorre noutros territoria mineiros toda a população seria vigiada e controlada por corpos auxiliares de legionários implicados na manutenção da ordem pública e no processo técnico da mineração (como no caso da preparação ou entivação de poços, abertura de canais ou mesmo na construção de vias de acesso) ${ }^{74}$. No caso do couto mineiro de Valongo conhece-se uma epígrafe que alude a um migrante assalariado ${ }^{75}$ que talvez se possa incluir nos liberi mercenari (locationes-conductiones operarum), igualmente responsáveis pelas obras de engenharia ${ }^{76}$. Todos os indivíduos implicados no processo de mineração possivelmente estariam na dependência de um procurador adjunto (provavelmente um liberto), responsável pela administração do distrito mineiro, supervisionado pela figura de um procurador diretamente nomeado pelo imperador.

\footnotetext{
${ }^{71}$ FUENTES DE LA ROSA, 2008: 246.

72 MORAIS, 2007b: 267-280.

${ }^{73}$ MORAIS, 2007b: 267-280.

${ }^{74}$ A presença militar no distrito de Três Minas está documentado pela epigrafia que testemunha a presença de dois militares pertencentes, respetivamente, à VII Legião e à cohorte gaulesa da cavalaria dos cidadãos romanos (ALMEIDA, 1970: 199).

${ }^{75}$ SILVA, 1984: 47; SILVA, 1986: 281.

${ }^{76}$ Sobre estas questões consultar RODRÍGUEZ ENNES, 1992: 426-427.
} 
Para além dos vestígios epigráficos acima mencionados e dos dados obtidos nos coutos mineiros situados nas proximidades do Douro, são de especial importância os materiais importados até à data recuperados junto à sua foz e em ambas as margens.

Na margem direita, situava-se, como referimos, Cale, que no decorrer do período imperial se tornará capital de civitas, controlando um vasto território. A função portuária do sítio prevaleceu sobre qualquer outra, demonstrando a sua importância enquanto plataforma viária na região. Os dados arqueológicos têm revelado uma expansão deste núcleo no período tardo-romano para a foz do rio da Vila (na zona da atual Ribeira), local onde se situariam as estruturas de apoio à navegação e do comércio fluvial e de cabotagem. Esta é talvez uma das razões para que durante o período suevo o núcleo tome o nome de Portus Cale, tal como aparece na Crónica de Idácio, datada do século $\mathrm{V}^{77}$.

De entre mais de uma centena de intervenções arqueológicas até à data realizadas nesta margem cabe destacar as do antigo Aljube, um cárcere criado nos meados do século XVIII, em 1749, situado na rua de S. Sebastião ${ }^{78}$. As escavações, realizadas a cargo de Joel Cleto, permitiram identificar potentes aterros realizados aquando da construção daquele edifício. Nestes aterros abundam distintos materiais romanos, com especial destaque para as cerâmicas importadas, representadas por sigillatas itálicas e ânforas datáveis da transição de milénio. No estudo de materiais que realizamos salientam-se as ânforas Haltern 70, com três dezenas de exemplares (cerca de $80 \%$ do material anfórico $)^{79}$, associadas a outras ânforas, em particular as chamadas ovoides lusitanas $^{80}$. Como já tivemos oportunidade de referir ${ }^{81}$, a sua presença permite demonstrar a importância desta região no contexto da chamada rota atlântica, no abastecimento e nos contactos regulares por via marítima, em particular com as províncias da Lusitânia e da Bética.

$\mathrm{Na}$ outra margem do rio vários têm sido os vestígios que também testemunham a importância comercial e económica da regiãa $0^{82}$. De entre estes refira-se a descoberta de uma muralha romana, de inícios a meados do século ${ }^{83}$, situada na encosta sudeste do Castelo de Gaia, numa pequena elevação junto à foz do Douro e usufruindo de uma privilegiada posição estratégica e de controlo. Neste local foi documentada uma ocupação que remonta pelo menos aos inícios da Idade do Bronze, mas com destaque para os vestígios de um povoado proto-histórico posteriormente romanizado e

\footnotetext{
77 SILVA, 1994.

${ }^{78}$ CARVALHO et al., 1996: 199-203.

${ }^{79}$ MORAIS \& CARRERAS MONFORT, 2004: 93-112; MORAIS, 2013: 101-136.

${ }^{80}$ MORAIS, 2004. 36-40; MORAIS, 2013: 101-136.

${ }^{81}$ MORAIS, 2013: 101-136.

${ }^{82}$ GUIMARÃES, 2000: 155-168.

${ }^{83}$ CARVALHO \& FORTUNA, 2000: 160.
} 
uma ocupação tardo-romana que se prolonga nos períodos suevo-visigóticos ${ }^{84}$. Num estudo que apresentámos com outros autores sobre as ânforas aí recolhidas pudemos constatar a presença de cerâmicas importadas ${ }^{85}$. Deste conjunto gostaríamos de salientar a presença de materiais itálicos datáveis dos finais da república, representados pelo tipo Dressel 1, nas suas respetivas variantes formais, e materiais tardo-romanos e suevo-visigóticos de origem norte africana e oriental. Nestes últimos predominam as ânforas oriundas do Mediterrâneo Oriental (tipos Late Roman 1, 2 e 3) e da área da Palestina (tipos Late Roman 4/Almagro 54 e LRA 5) e Egito (tipo Late Roman 7). As produções africanas são de fabrico tunisino e estão representadas pela forma Keay LXII. No conjunto das produções cerâmicas, saliente-se a presença de sigillatas que parecem acompanhar aqueles produtos. É o caso de produções itálicas, enquadráveis no período da transição de milénio e a primeira década do século I, e de produções tardias de origem africana e foceense. A par destas cerâmicas finas refira-se ainda a presença de fragmentos de lucernas e de cerâmicas comuns com um fabrico afim aos das ânforas Late Roman 1. Estes dados conhecidos para o Castelo de Gaia, encontram paralelo noutras estações arqueológicas situada nesta margem do rio, como é o caso das escavações do Bom Jesus de Gaia e do já mencionado cais romano de Crestuma.

\section{CONSIDERAÇÕES FINAIS}

A navegabilidade no canal do Douro, apesar das muitas dificuldades já mencionadas, era vantajosa economicamente não só para comercialização de produtos mas também para a circulação de pessoas e animais. O curso fluvial serviu como eixo articulador do povoamento. A ocupação do território fez-se em grande medida em função da sua presença.

Apesar do rio ter servido como linha de fronteira natural, as duas margens funcionaram de modo simbiótico. Estamos assim perante uma dupla natureza do rio, por um lado, como linha de fronteira e, por outro, como ponto de ligação entre as duas margens. Mas para que essa relação simbiótica fosse uma realidade na vida diária das populações era obrigatório a constante comunicabilidade através de barcas de passagem. A travessia seria realizada a partir de locais de mais fácil acessibilidade, tal como se documenta para a Idade Média ${ }^{86}$, certamente recalcando velhos itinerários romanos.

$\mathrm{Na}$ região a montante do rio, pode considerar-se que as atividades vitivinícolas remontam à época romana, como se pode comprovar pelos inúmeros lagares e lagaretas (torcularia) e pelas áreas de armazenamento de vinho (apothecae) que têm vindo a ser descobertas.

\footnotetext{
${ }^{84}$ GUIMARÃES, 2000: 158-162.

${ }^{85}$ SILVA et al., 2017.

${ }^{86}$ PEREIRA \& BARROS, 2001: 133-148.
} 
Deve ainda salientar-se a importância de se ter documentado a produção de dolia e do seu comércio a nível regional. Mas não devemos esquecer o uso de outro tipo de contentores cerâmicos usados no armazenamento e no comércio do vinho, como, por exemplo, as ânforas de fundo plano e o uso de recipientes ou vasilhames perecíveis (odres, barris, sacos, cestos, etc.), frequentemente ocultos no registo arqueológico.

Mas a história do Douro ficaria incompleta se não apreciássemos os materiais cerâmicos importados que têm vindo a ser recuperados na desembocadura do rio Douro. Como sugerimos, o seu estudo parece testemunhar duas realidades distintas: na margem setentrional, do lado do Porto, os materiais romanos importados parecem ser abundantes ao longo de todo o período imperial e, na margem meridional, do lado de Gaia, parece haver uma maior concentração de materiais cerâmicos importados do período tardo-republicano e finais do império, entrando já no período suevo-visigótico. Apesar de esta diferença necessitar de ser corroborada com mais dados de outras escavações e de estudos quantitativos que possam confirmar ou infirmar esta análise, tudo indica que os materiais de época imperial recuperados na margem setentrional possam estar associados à importância de Cale enquanto centro administrativo e político; os materiais tardo-republicanos e tardo-antigos da margem meridional deverão enquadrar-se no contexto das melhores condições naturais desta margem para o embarque e desembarque de produtos.

\section{BIBLIOGRAFIA}

ALARCÃO, Jorge de (2005) - Notas de arqueologia, epigrafia e toponímia - III. «Revista Portuguesa de Arqueologia», vol. 8, n.o 2. Lisboa: Instituto Português de Arqueologia (IPA), p. 293-311.

ALMEIDA, Carlos Alberto Brochado de (1996) - O Cultivo da vinha durante a Antiguidade Clássica na Região Demarcada do Douro. Ponto da situação. «Douro - Estudos \& Documentos», n. ${ }^{\circ} 2$. Porto: GEHVID, p. 18-30.

(2006) - O Cultivo da vinha na Antiguidade Clássica. In ALMEIDA, Carlos Alberto Brochado de, coord. - História do Douro e do Vinho do Porto. História Antiga da Região Duriense. Porto: GEHVID/Edições Afrontamento, vol. 1, p. 348-405.

ALMEIDA, Carlos Alberto Brochado de; PINTO, Paulo J. Costa; ALMEIDA, Pedro Miguel D. Brochado de (1997) - Os lugares cavados na rocha do castelo de Castorigo - Pegarinhos (Alijó). «Douro Estudos \& Documentos», n. ${ }^{\circ}$ 4. Porto: GEHVID, p. 15-24.

ALMEIDA, Carlos Alberto Ferreira (1968)- Vias Medievais I. Entre-Douro-e-Minho. Porto: [s.n.]. Policopiado.

ALMEIDA, D. Fernando de (1970) - Minas de ouro na «Gallaecia» portuguesa. In Coloquio Internacional de Romanistas. Léon: Instituto leonés de estudios romano-visigóticos, p. 289-301.

ALVES, J.; TORRES, J. (2002) - Douro \& Leixões. A vida portuária sob o signo dos bilhetes postais. Porto. AMORIM, Inês (1986) - Projectos de um canal interior, ligando o Douro à Ria de Aveiro. In $1 .^{\circ}$ Congresso Internacional sobre o Rio Douro. Livro do Congresso. Vila Nova de Gaia: Gabinete de História e Arqueologia de Vila Nova de Gaia, p. 19. 
ANTUNES, João M. V.; FARIA, Pedro F. B. de (2006) - O povoamento antigo. In ALMEIDA, Carlos Alberto Brochado de, coord. - História do Douro e do Vinho do Porto. História Antiga da Região Duriense. Porto: GEHVID/Edições Afrontamento, vol. 1, p.188-283.

ARRUDA, Ana; VILAÇA, Raquel (2006) - O Mar Greco-Romano antes dos Gregos e Romanos. Perspectivas a partir do Ocidente Peninsular. In OLIVEIRA, Francisco de; THIERCY, Pascal; VILAÇA, Raquel, coord. - Mar Greco Latino. Coimbra: Imprensa da Universidade de Coimbra, p. 31-58.

BARBOSA, J. Novais (2008) - Desta água beberei. A água na terra. In PEREIRA, Gaspar Martins, coord. - As águas do Douro. Porto: Edições Afrontamento, p. 309-341.

BARROS, Amândio Jorge Morais; PEREIRA, Gaspar Martins (2008) - O Douro na História. Introdução: uma crónica do Douro. In PEREIRA, Gaspar Martins, coord. - As águas do Douro. Porto: Edições Afrontamento, p. 13-61.

BLANCA GARCÍA, Maria; ALBALÁT, F. (1986) - ¿Un ara votiva a durius? Valor religioso de los rios en la antigüedad. In $1^{\circ}$ Congresso Internacional sobre o Rio Douro. Livro do Congresso. Vila Nova de Gaia: Gabinete de História e Arqueologia de Vila Nova de Gaia, p. 15.

BLANCO FREIXEIRO, Antonio (1992) - Monumentos romanos de la conquista de Galicia. "La romanización de Galicia». 2. ${ }^{\text {a }}$ ed. La Coruña: Ediciones del Castro, p. 95-104.

CARDOSO, António Barros (2002) - Subsídios para a História da barra do Douro (1704-1747). In O Litoral em perspectiva Histórica. Sécs. XVI a XVIII. Actas. Porto: Faculdade de letras, p. 225-245. (2012) - Douro - um rio selvagem em finais de setecentos. In MARTINS, Manuela; FREITAS, Isabel Vaz de; VAL VALDIVIESO, $\mathrm{M}^{\mathrm{a}}$ Isabel del, eds. - Caminhos da água. Paisagens e usos na longa duração. Braga: CITCEM, p. 237-252.

CARVALHO, Teresa Pires; FORTUNA, Jorge (2000) - Muralha romana descoberta no castelo de Gaia.

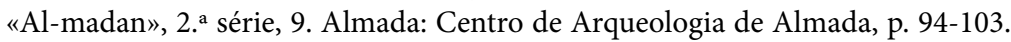

CARVALHO, Teresa Pires; GUIMARÃES, Carlos; BARROCA, Mário (1996) - Bairro da Sé do Porto: contributo para a sua caracterização histórica. Porto: Câmara Municipal do Porto.

CHIC GARCÍA, Genaro (1978) - Consideraciones sobre la navegabilidad del Guadalquivir en época romana. «Gades», n. ${ }^{\circ}$ 1, Cádiz, p. 7-20.

(1984) - El tráfico en el Guadalquivir y el transporte de las ánforas. "Anales de la Universidad de Cádiz», n. ${ }^{\circ}$ 1, Cádiz, p. 33-44.

COIXÃO, António Nascimento Sá (2017) - A romanização do Baixo Côa. Dissertação de doutoramento em Estudos do Património - Arqueologia, Porto: policopiado.

COIXÃO, António Nascimento Sá; MAZA, Guillaume; SILVINO, Toni (2005) - Le Complexe Artisanal du Rumansil I (Murça-do-Douro, Vila Nova de Foz Côa). «Coavisão», 5. Vila Nova de Foz Côa, p. 85-97.

CORTES, Rui (2008) - Rio Douro: Caracterização ecológica e valores ambientais. O Rio Douro nas suas origens. In PEREIRA, Gaspar Martins, coord. - As águas do Douro. Porto: Edições Afrontamento, p. 199-228.

COUTINHO, Maria Beatriz F. Tato Leite; BARROTE, Maria Alexandra M. Barbosa (1986) - Cheias do Rio Douro. In $1 .{ }^{\circ}$ Congresso Internacional sobre o Rio Douro. Livro do Congresso. Vila Nova de Gaia: Gabinete de História e Arqueologia de Vila Nova de Gaia, p. 18.

DIAS, Lino Tavares (2006) - Contributo para o estudo do povoamento no Vale do Douro. In ALMEIDA, Carlos Alberto Brochado de, coord. - História do Douro e do Vinho do Porto. História Antiga da Região Duriense. Porto: GEHVID/Edições Afrontamento, vol. 1, p. 285-331.

DUARTE, Luís Miguel; BARROS, Jorge Morais (1997) - Corações aflitos: navegação e travessia do Douro na Idade Média e no início da Idade Moderna. «Douro - Estudos \& Documentos», n. ${ }^{\circ} 4$. Porto: GEHVID, p. 77-118. 
ESCACENA CARRASCO, José Luís; PADILLA MONGE, Aurelio (1992) - El poblamiento romano en las márgenes del antiguo estuario del Guadalquivir. Écija-Sevilla: Gráficas Sol.

FERNANDES, Lídia (2016) - Viagem ao passado romano na Lusitânia. Lisboa: Esfera dos Livros.

FERNANDES, Luís Azeredo de Sá (1944) - Esbôç̧o Litológico da Região Duriense. Porto: Ministério da Ecomomia/Direcção Geral de Minas e Serviços Geológicos.

FERREIRO LOPEZ, Manuel Ángel (1988) - La campaña militar de Cesar en el año 61. In MENAUT, G. P., ed. - Actas 1er Congreso Peninsular de Historia Antigua. Santiago de Compostela: Universidad de Santiago de Compostela, vol. II, p. 363-372.

FRADE, Helena (1998) - Ara a Júpiter da Civitas Cobelcorum. «Ficheiro Epigráfico», vol. 58, n. 266. Coimbra.

FUENTES DE LA ROSA, Maria Luísa (2008) - El Ebro: en el corazón de Hispania. In MIER, Emilia Fernández de; VILLA, Jesús de la, eds. - Las Venas del Mundo. Los ríos de la Antigüedad. Madrid, p. 217-250.

GUIMARÃES, J. A. Gonçalves (2000) - Um século de arqueologia em Vila Nova de Gaia. «Al-madan», $2^{\text {a }}$ série, 9. Almada: Centro de Arqueologia de Almada, p. 155-168.

GUIMARÃES, J. A. Gonçalves; GUIMARÃES, Susana Gonçalves (2001) - O Castelo de Crestuma, uma estação arqueológica quase desconhecida. "Al-madan», 2a série, 10. Almada: Centro de Arqueologia de Alamada, p. 43-47.

IZARRA, François (1993) - Hommes et fleuves en Gaule romaine. Paris: Errance.

LOPES, Francisco (2008) - Um rio para navegar. O rio Douro e o canal navegável. In PEREIRA, Gaspar Martins, coord. - As águas do Douro. Porto: Edições Afrontamento, p. 275-307.

MARTÍNEZ MERA, Josefa (2001) - Expedicións militares a Gallaecia na época republicana. «Gallaecia», 20. Santiago de Compostela, p. 297-316.

MONTEIRO, Manuel (1998) - O Douro. Principaes Quintas, Navegação, Culturas, Paisagens e Costumes. Lisboa: Livro Branco. Fac-similada ed. do Porto: Emílio Biel, 1911.

MORAIS, Rui; CARRERAS MONFORT, César (2004) - Geografia del consum de les Haltern. In Culip VIII i les àmfores Haltern 70, «Monografies del Casc», 5. Girona, p. 93-112.

MORAIS, Rui (2004) - Problemàtiques i noves perspectives sobre les àmphores ovoides tardo-republicanes. Les àmphores ovoides de producció Lusitana. In Culip VIII i les àmfores Haltern 70, «Monografies del Casc» 5. Girona, p. 36-40.

(2005) - Autarcia e Comércio em Bracara Augusta. Contributo para o estudo económico da cidade no período Alto-Imperial. «Bracara Augusta, Escavações Arqueológicas 2». Braga: UAUM/Narq. (2007a) - A via atlântica e o contributo de Gádir nas campanhas romanas na fachada noroeste da península. «Humanitas», 58. Coimbra: Instituto Clássico e Humanístico, p. 99-132.

(2007b) - Ânforas da Quinta da Ivanta. Um pequeno «habitat» mineiro em Valongo. «Conimbriga», vol. XLVI, Coimbra: Instituto de Arqueologia, p. 267-280.

(2013) - Durius e Leça: dois percursos de um mesmo itinerário - problemáticas em torno das ânforas Haltern 70. In «Portvgalia». Nova série, vol. 34, Porto: DCTP/FLUP, p. 101-136.

OLIVEIRA, Francisco de (2014) - Vasos e vasilhame em Plínio o Naturalista. In MORAIS, Rui; FERNÁNDEZ, Adolfo; SOUSA, Ma José, eds. - II Congresso Internacional da SECAH - EX OFFICINA HISPANA, Tomo I, Braga, p. 15-34.

ORDÓÑEZ AGULLA, Salvador (2003) - El puerto romano de Hispalis. In BERLANGA, Guillermo Pascual; BALLESTER, José Pérez, eds. - Puertos fluviales antiguos: ciudad, desarrollo e infraestruturas. Actas. IV Jornadas de Arqueología subacuática. Valencia, p. 59-79.

OSÓRIO, Maria Isabel (1993) - Um lugar na cidade: S. João da Foz. In OSÓRIO, M. I. N. P., coord. - O Porto das mil idades: arqueologia na cidade [roteiro]. Porto: Câmara Municipal, p. 25-34. 
OSÓRIO, Maria Isabel; SILVA, António Manuel S. P. (1994) - Intervenção arqueológica municipal do Porto. Resultados problemas e potencialidades. In Actas do $2^{\circ}$ Encontro de Arqueologia Urbana. «Bracara Augusta», XLV/94, Braga, p. 87-98.

PARODI ÁLVAREZ, Manuel J. (2001) - Ríos y lagunas de Hispania como vías de comunicación: la navegación interior en la Hispania romana. Écija-Sevilla: Gráficas Sol.

PEREIRA, Gaspar Martins (2003) - A evolução histórica. In Viver e saber fazer. Tecnologias tradicionais na Região do Douro. Estudos preliminares. Museu do Douro: Peso da Régua, p. 103-127.

PEREIRA, Gaspar Martins; BARROS, Amândio Jorge Morais (2001) - Memória do Rio. Para uma história da navegação no Douro. Porto: Edições Afrontamento.

PEREIRA, Pedro; MORAIS, Rui (2016) - Estudo crono-tipológico de dolia romanos em Portugal. «Ex Officina Hispana - Cuadernos de la Secah», 2. Bilbao, p. 33-44.

REDENTOR, Armando (2011) - A cultura epigráfica no conuentus Bracaraugustanus: percursos pela sociedade brácara da época romana. Coimbra: tese policopiada.

RODRÍGUEZ ENNES, Luis (1992) - Extracción social y condiciones de trabajo de los mineros hispanoromanos. «Gallaecia», no 13. Santiago de Compostela, p. 423-431.

SIERRA DE CÓZAR, Ángel (2008) - El Tíber en la Antigüedad. In MIER, Emilia Fernández de; VILLA, Jesús de la, eds. - Las Venas del Mundo. Los ríos de la Antigüedad. Madrid, p. 81-130.

SILVA, Armando Coelho Ferreira da (1984) - Aspectos da proto-história e romanização no concelho de Vila Nova de Gaia e problemática do seu pensamento. «Gaya», 2, Vila Nova de Gaia: Gabinete de História e Arqueologia, p. 39-58. (1986) - A Cultura Castreja no Noroeste de Portugal. Paços de Ferreira. (1994) - As origens do Porto. In RAMOS, L. A. O. ed. - História do Porto. Porto: Porto Editora. (2000) - Proto-história e romanização do Porto. «Al-madan», 2a série, 9. Almada: Centro de Arqueologia de Alamada, p. 94-103.

SILVA, António Manuel S. P. (2010) - Ocupação da época romana na cidade do Porto: ponto da situação e perspectivas de pesquisa. «Gallaecia», $\mathrm{n}^{\circ}$ 29. Santiago de Compostela, p. 213-262.

SILVA, António Manuel S. P.; GUIMARÃES, J. A. Gonçalves (2013a) - Castelo de Crestuma. A Arqueologia em busca da história. Vila Nova de Gaia: Águas e Parque Biológico de Gaia/Confraria Queirosiana. (2013b) - O Castelo de Crestuma (Vila Nova de Gaia) e a ocupação tardo-antiga no Baixo Douro. In Arqueologia em Portugal 150 anos. Lisboa: AAP, p. 883-893.

SILVA, António Manuel S. P.; MORAIS, Rui; PINA-BURÓN, María R.; PRIETO DE LA TORRE, Roger (2017) - Cerâmica romana importada na Foz do Douro: uma escavação arqueológica no Castelo de Gaia (V. N. Gaia, Norte de Portugal). In ROSAS, Lúcia; SOUSA, Ana C.; BARREIRA, Hugo - Genius Loci: lugares e significados; places and meanings. Porto: CITCEM, vol. II, p. 315-331.

SILVA, Pinto da (1986) - As cheias do Douro. In $1 .^{\circ}$ Congresso Internacional sobre o Rio Douro. Livro do Congresso. Vila Nova de Gaia: Gabinete de História e Arqueologia, p. 37.

SOEIRO, Teresa (2006) - Douro, um rio de vida. In Viver e saber fazer. Tecnologias tradicionais na Região do Douro. Estudos preliminares. Peso da Régua: Museu do Douro, p. 359-412.

TOVAR, Antonio Llorente (1975) - La conquista romana. In TOVAR, Antonio Llorente; BLÁZQUEZ MARTÍNEZ, José María, coord. - Historia de la Hispania Romana: la Península Ibérica desde 218 a.C. hasta el siglo V. Madrid: Alianza Editorial, p. 9-121.

TRANOY, Alain (1981) - La Galice romaine. Recherches sur le Nord-Ouest de la péninsule ibérique dans l’Antiquité. Paris: De Boccard.

(1995) - La Rive Nord du Douro à l'époque romaine: contribution épigraphique à l'étude d'une zone frontière. «Gaya», 6, Vila Nova de Gaia: Gabinete de História e Arqueologia, p. 125-136. 



\title{
CALE CALLAECORUM LOCUS? \\ NOTAS ARQUEOLÓGICAS SOBRE A \\ OCUPAÇÃO INDÍGENA E ROMANA DA \\ FOZ DO DOURO
}

\author{
ANTÓNIO MANUEL S. P. SILVA*
}

A interrogação com que titulamos este breve ensaio convoca duas importantes questões de geo-etnologia histórica: a primeira, largamente debatida, é hoje de carácter mais arqueológico que toponímico, pois enquanto esta disciplina versa o estudo do nome dos lugares, na discussão de Cale disputa-se ainda o lugar onde assentar a designação; a segunda traz à lide a definição e localização dos primitivos Callaici, étnico cuja ambiguidade a generalização do uso não disfarçou totalmente. Ambos os tópicos ocuparam já eminentes especialistas e pouco de novo poderemos seguramente trazer, contentando-nos com a expectativa de que estas observações contribuam, por alguma frescura de perspectiva, para reposicionar temas tão cruciais para a história antiga do baixo Douro.

As fontes literárias que mencionam o lugar de Cale são tão escassas quanto conhecidas, tendo a ambiguidade dessas referências dado origem a longa discussão historiográfica que aqui não pretendemos retomar ${ }^{1}$. Basicamente, resumem-se a uma menção no Itinerário de Antonino, sendo as formas em que surge na Cosmografia do Anónimo de Ravena e na Crónica de Idácio já compósitas ou vagamente aparentadas².

\footnotetext{
* Bolseiro de Doutoramento da FCT na Universidade de Santiago de Compostela. Investigador do CITCEM - Centro de Investigação Transdisciplinar Cultura, Espaço e Memória (UP) e do projeto Las fundaciones urbanas de Callaecia y la creacion de un nuevo espacio administrativo (USC-HAR2014-51821-P). amspsilva@hotmail.com.

${ }^{1}$ Cf. SILVA, 2010 para uma discussão mais aprofundada desta questão, com remissão para vasta bibliografia.

${ }^{2}$ GUERRA, 1998: 369-70.
} 
O roteiro viário indica o lugar de Calem como última estação antes de Bracara Augusta, distando XIII milhas da statio anterior, que é Langobriga ${ }^{3}$. Não entrando no debate sobre a contagem das milhas, sobre o valor da milha romana ou mesmo sobre a localização do ponto anterior, Lancóbriga ${ }^{4}$, a implantação da statio ou mutatio de Cale seria sempre numa das margens do Douro. Admitindo a explicação do acusativo de proximidade para a forma como surge grafada a designação da estação viária ${ }^{5}$, parece-nos perfeitamente razoável que ficasse situada em Vila Nova de Gaia, mas tomando o nome e indicando a localidade, porventura mais destacada, situada na outra margem: (ad) Calem. Assenta esta sugestão, tão só, nas condições orográficas da margem gaiense, com escarpas pronunciadas e escasso número de linhas de água afluentes do Douro, tornando custoso o acesso ao rio no período de Inverno, como vários viajantes estrangeiros atestaram ainda em época moderna ${ }^{6}$, o que talvez recomendasse breve estância na margem esquerda antes do atravessamento de um rio largo e que nos meses invernosos, com as cheias regulares, se mostrava torrentoso e de difícil travessia; naturalmente, o viajante que chegasse da Tarraconense teria problema idêntico, mas talvez maior facilidade em chegar às margens do Douro, onde certamente existiriam também cómodos para refresco e descanso, pois o Itinerário apenas elenca as estações viárias que se entenderam mais importantes.

A referência às localidades da margem do Douro patente na Cosmographia anónima de Ravena, compilação tardia que talvez conserve a tradição de um documento cartográfico latino dos séculos III ou IV, introduz no debate a variante cenoopi docalo ${ }^{7}$, que Vasco Mantas ${ }^{8}$, na senda de Hübner ${ }^{9}$, desdobra e interpreta como estações viárias diferentes, corrigindo a grafia: CAENO OPPIDUM e $C A L O^{10}$, atribuindo a primeira designação ao Castelo de Gaia (Fig. 1), posição que mais recentemente A. C. Ferreira da Silva ${ }^{11}$ adoptou, tecendo a propósito interessantes considerações etno-linguísticas. Sem que nos aventuremos em área científica que não dominamos

\footnotetext{
${ }^{3}$ ROLDÁN, 1975: 68.

${ }^{4}$ Aceite quase unanimemente, a partir das distâncias do Itinerário de Antonino, como correspondendo ao castro de Fiães, Santa Maria da Feira (cf. MANTAS, 1996: 640-45; SILVA, 1994: 54, 95).

${ }^{5}$ SOARES, 1962: 150; ROLDÁN, 1966; MANTAS, 1996: 201-3.

${ }^{6}$ Por exemplo, o arquitecto irlandês James Murphy, que chegou por barco ao Porto em Janeiro de 1789, descreve não só as dificuldades e os perigos da entrada na barra como também o difícil trajecto desde a margem de Gaia até aos Carvalhos, lamentando que «there is not a perch of what we should call a road», sendo por isso forçoso que quatro trabalhadores galegos que acompanhavam a excursão interviessem amiúde para auxiliar as mulas e desatolar a carruagem atascada na lama (MURPHY, 1795: 2, 18).

${ }^{7}$ ROLDÁN, 1975: 123.

${ }^{8}$ MANTAS, 1996: 645-51.

${ }^{9}$ HÜBNER, 1871: 67-8.

${ }^{10}$ Correcção aceite por A. GUERRA (GUERRA, 1998: 369), que todavia considera a leitura Calo, como aparentemente um nome de tema em $-o$.

11 SILVA, 2015.
} 


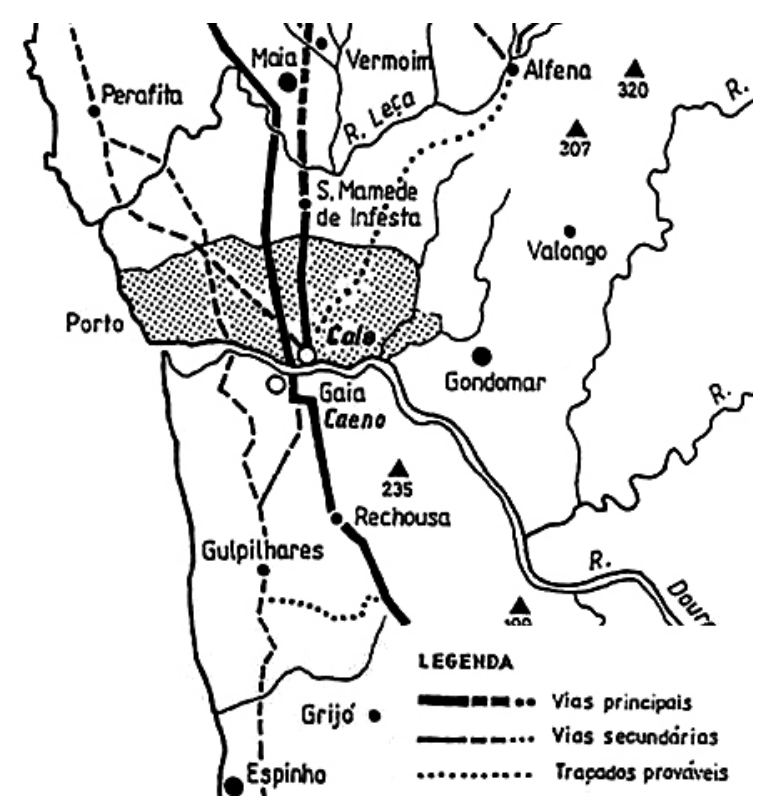

Fig. 1.

Vias romanas nas imediações do Baixo Douro, segundo V. Mantas, que localiza Cale no Porto e Caeno em Gaia.

Adaptado de MANTAS, 1996.

mas partilhando as dúvidas de J. Alarcão ${ }^{12}$ acerca do desdobramento, pode dizer-se que a principal dúvida interpretativa será entre as hipotéticas localidades de [Caeno oppidum + Calo $]$ ou [Caeno + Oppidum Calo] questão interessante sobretudo porque parece estabelecer algum tipo de diferenciação ou hierarquia entre ambos os povoados, tendo em vista o significado do substantivo oppidum mesmo em época tardia ${ }^{13}$. As referências de Idácio, pluriformes e com variantes conforme os manuscritos, remetem para contextos toponímicos de época diferente da que particularmente nos interessa e são, neste plano, mais um ponto de chegada que de partida, pelo que importam menos a este texto ${ }^{14}$.

Se na célebre enumeração das 24 ciuitates do convento bracaraugustano feita por Plínio ${ }^{15}$ o termo Callaeci alude a uma subunidade étnica precisa e perfeitamente distinta das vizinhas ainda pelos meados do século I e não é - como sugeriu Untermann ${ }^{16} \mathrm{e}$ quase parece ter admitido o maior estudioso da etnogénese galaica, Gerardo Pereira ${ }^{17}$ - um mero qualificativo dos Coelerni para os distinguir dos Colarni da Lusitânia, a

\footnotetext{
12 ALARCÃO, 2005: 305.

${ }^{13}$ Contrariamente às acepções da historiografia arqueológica, o termo é usado nos textos legais latinos como «un identificador genérico de ciudades [...] pero que tiene en cuenta su importancia simbólica y jurídica, pues nunca se asoció a poblaciones menores o poco importantes» (FUMADÓ, 2013: 181).

${ }^{14}$ Cf. SILVA, 2010; REAL \& SILVA, [no prelo].

${ }^{15}$ Nat. Hist., III, 28.

${ }^{16}$ UNTERMANN, 1993: 383.

17 PEREIRA-MENAUT, 1998b: 44-5.
} 
Fig. 2.

Principais povos pré-romanos do Baixo Douro, segundo A. C. Ferreira da Silva (2007).

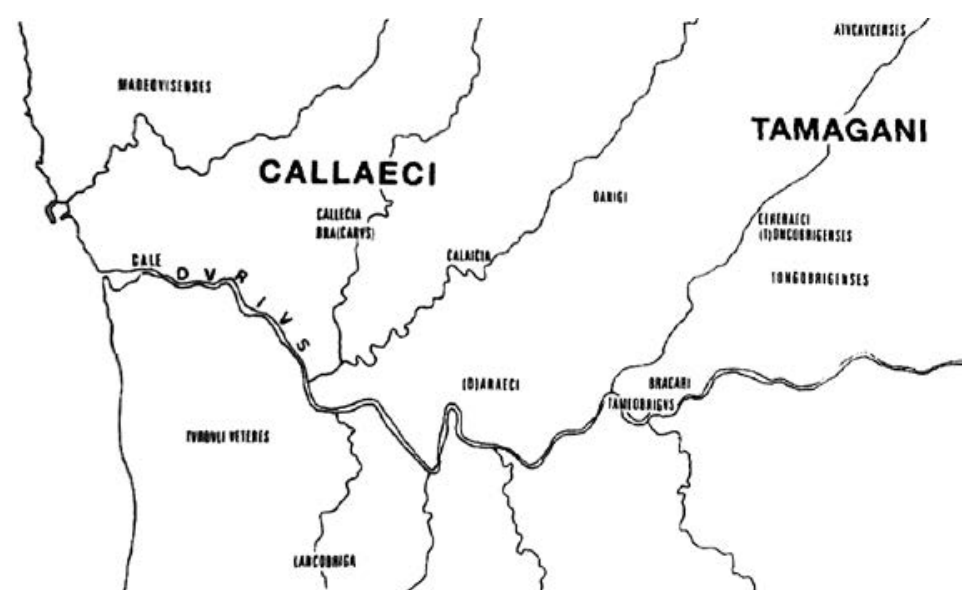

sua localização na margem Norte da foz do Douro é praticamente consensual ${ }^{18}$ (Fig. 2), sendo escassos os investigadores com posições diferentes, como A. Rodriguez Colmenero, que situa o território dos ditos Callaeci além do rio Tâmega, sem propor qualquer povoado como caput ciuitatis, e considerando que seriam antes os bracari a ocupar as imediações de Cale ${ }^{19}$, que todavia situa no Porto ${ }^{20}$. Mais recentemente, Lino T. Dias localizou os Callaeci Bracari, grafados como étnico maior, na região delimitada a Nascente pelo Marão, a Sul pelo Douro e a Oeste pela região dos rios Sousa e Ferreira ${ }^{21}$, entendendo em consequência que Tongobriga seria a ciuitas mais ocidental da bacia norte do Douro, estendendo-se até ao Oceano ${ }^{22}$ e não deixando, por conseguinte, espaço para outros territórios na foz daquele rio.

Ainda assim, a interrogação que encima este ensaio não é totalmente retórica, pois sendo muito provável, em nosso entender, que Cale seja o nome do povoado indígena que originou a moderna cidade do Porto e que fossem callaeci os que aí habitavam e foram - para sua desgraça e honra dos vencedores - os primeiros a afrontar Decimus Iunius Brutus, não são certos o estatuto e capitalidade do sítio ainda que diversos autores coincidam em considerar Cale como um lugar-central, senão político pelo menos como port of trade comercial $^{23}$ - e é grandemente desconhecido o seu processo de urbanização e integração na órbita romana, questões para as quais apenas a arqueologia pode ir sugerindo algumas informações.

\footnotetext{
${ }^{18}$ TRANOY, 1981: 65-6; ALARCÃO, 1995-96; 1999; SILVA, 1996; SILVA, 1999; SILVA, 2000; SILVA, 2013.

${ }^{19}$ RODRIGUEZ COLMENERO, 1997: 17-29.

${ }^{20}$ RODRIGUEZ COLMENERO \& FERRER SIERRA, 2014: 248.

${ }^{21}$ DIAS, 2016: 47 (mapa).

${ }^{22}$ DIAS, 2016: 75.

${ }^{23}$ SILVA, 2000: 100-101; SILVA, 2013: 42-3; GONZÁLEZ RUIBAL, 2006-2007: 348.
} 


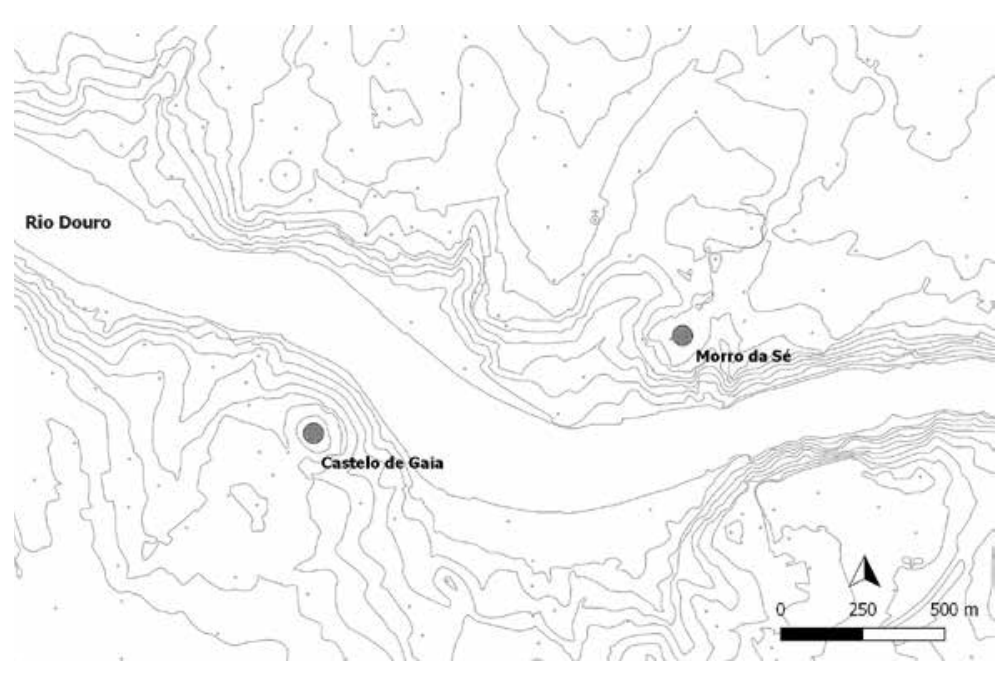

Fig. 3.

Localização do Castelo de Gaia e do Morro da Sé (Porto), os principais aglomerados indígenas e romanos da foz do Douro.

Cartograma do Autor.

A relativa simetria geográfica dos principais aglomerados populacionais de ambas as margens, o morro da Sé ou da Penaventosa e a colina de Gaia (Fig. 3), tem tradução tanto a nível cronológico, pois ambos os povoados remontarão aos finais da Idade do Bronze ${ }^{24}$, como porventura no seu desenvolvimento ao longo do primeiro milénio antes da nossa era, sendo mais desconhecidas as formas e consequências das transformações que sofreram no quadro do domínio romano e das subsequentes dinâmicas económicas e socioculturais.

A informação sobre o povoamento antigo das duas elevações é bastante desigual em resultado das diferentes circunstâncias que trouxeram os lugares até aos dias de hoje e do contexto dos trabalhos arqueológicos ali efectuados. No Castelo de Gaia, a evolução urbanística dos últimos séculos - que não conseguiu apagar a disposição concêntrica e outros traços da malha construída medieval - deixou livre no topo e pelas encostas uma expressiva mancha de terrenos, que desde há duas ou três décadas vêm sendo progressivamente desafectados do anterior uso agrícola ou de pasto para largos projectos imobiliários, suscitando, no cumprimento da legislação de salvaguarda patrimonial ${ }^{25}$, intervenções de arqueologia preventiva que incidem sobre áreas bastante significativas ${ }^{26}$, proporcionando a identificação de vestígios relativamente extensos das primeiras ocupações do sítio. No portuense morro da Sé, cuja trama urbana, igualmente de feição medieva, se densificou extraordinaria-

\footnotetext{
${ }^{24}$ SILVA, 1984: 46; SILVA, 1994: 71; CARVALHO, 2003: 826-7; REAL et al., 1985-1986: 28.

${ }^{25}$ A área do Castelo de Gaia está classificada como Imóvel de Interesse Público desde 1990 (Dec. n. $29 / 90$ de 27 de Junho), sendo também abrangida pelas zonas de protecção de outros bens culturais próximos.

${ }^{26}$ Exemplo destas circunstâncias são as sondagens, escavações arqueológicas e acompanhamentos de obra feitos no quadro de projectos de operações urbanísticas como os da Taylor Fonseca S.A., da Quinta de São Marcos ou do Gaveto de Entre-Quintas. Cf. SILVA, 2017 para um conspecto geral.
} 
mente, reduzindo o parcelário e as manchas não edificadas, as intervenções de avaliação prévia de projectos imobiliário ${ }^{27}$ são em número talvez dez vezes superior às que se verificam em $\mathrm{Gaia}^{28}$. Todavia, espartilham-se por reduzidos lotes de poucas dezenas de metros quadrados de superfície, somando-se à menor preservação dos restos arqueológicos a escassa dimensão das observações arqueológicas efectuadas, quer em superfície, quer por vezes em profundidade, como resultado também da metodologia de avaliação seguida.

De comum entre as duas margens, importa observar, o reduzidíssimo número de intervenções arqueológicas feitas com propósito de investigação e não apenas impostas por projectos imobiliários, que, além do mais, ordinariamente não admitem a preservação de quaisquer vestígios arqueológicos. E também, a acrescer a esta circunstância, refira-se o escasso investimento feito no estudo e publicação dos resultados destes trabalhos de minimização dos impactes arqueológicos negativos das intervenções urbanísticas. Com estas notas prévias, queremos lembrar que há que matizar um pouco a necessária analogia entre os vestígios de ocupação antiga dos dois povoados ribeirinhos, sopesando a par dos resultados da arqueologia as condições da sua prática em ambas as margens.

Num e noutro núcleo têm vindo a ser identificadas diversas construções do povoado indígena, intersectando-se ou coexistindo as de plano curvilíneo com as de planta ortogonal, como é próprio dos últimos séculos da Idade do Ferro. No Castelo de Gaia, onde como vimos são geralmente mais amplas as áreas intervencionadas, puderam observar-se bons exemplos desta realidade, por exemplo, nos trabalhos efectuados para a construção do edifício da Taylor Fonseca S. A. ${ }^{29}$, na Quinta de São $\operatorname{Marcos}^{30}$ ou mais recentemente no projecto em curso nos armazéns do antigo Hard Club ${ }^{31}$ (Fig. 4).

No primeiro daqueles lugares, situado na encosta sudeste do morro, voltada ao Douro, foram encontrados restos de estruturas de diferentes épocas, nomeadamente duas construções de planta circular datadas pelos responsáveis da intervenção como dos finais da Idade do Ferro (Fig. 5), bem como vários muros da época romana e tardo-antiga ${ }^{32}$. Na vertente norte da colina, em local designado como Quinta de São Marcos, as escavações puseram também à vista numerosas estruturas da Idade do Ferro e época romana, com casas redondas e diversos muros rectilíneos, canalizações,

\footnotetext{
${ }^{27}$ Igualmente por constituir zona classificada em resultado da presença de diversos monumentos nacionais e de interesse público e sendo, desde 1996, parte da zona definida como Património Cultural da Humanidade pela UNESCO.

${ }^{28}$ Como natural consequência da maior dinâmica urbanística da cidade do Porto e da localização do seu polo histórico gerador, que é central nesta cidade, enquanto em Vila Nova de Gaia se acha desde há séculos algo excêntrico, favorecendo o abandono e degradação de que foi objecto pelo menos durante o século XX (AFONSO et al., 1989).

${ }^{29}$ CARVALHO \& FORTUNA, 2000; CARVALHO, 2003.

${ }^{30}$ SOUSA \& PIEDADE, 2008.

${ }^{31}$ BARBOSA \& PRIETO, 2011.

${ }^{32}$ CARVALHO, 2003: 827-9.
} 


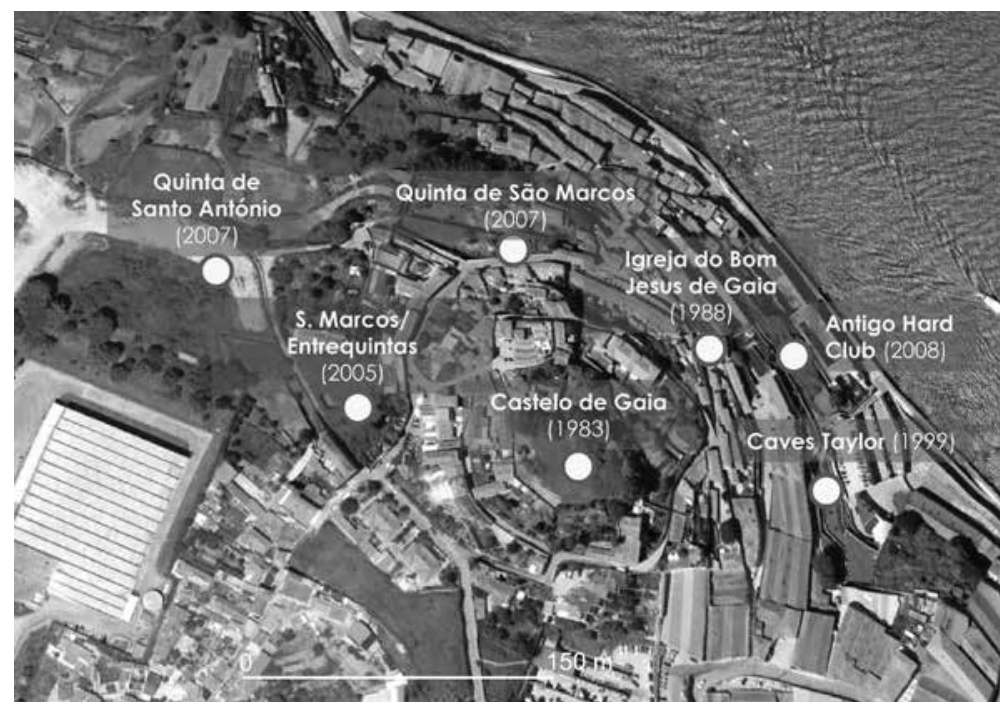

Fig. 4.

Principais intervenções arqueológicas no Castelo de Gaia, 1983-2008.

Reprodução de SILVA, 2017.

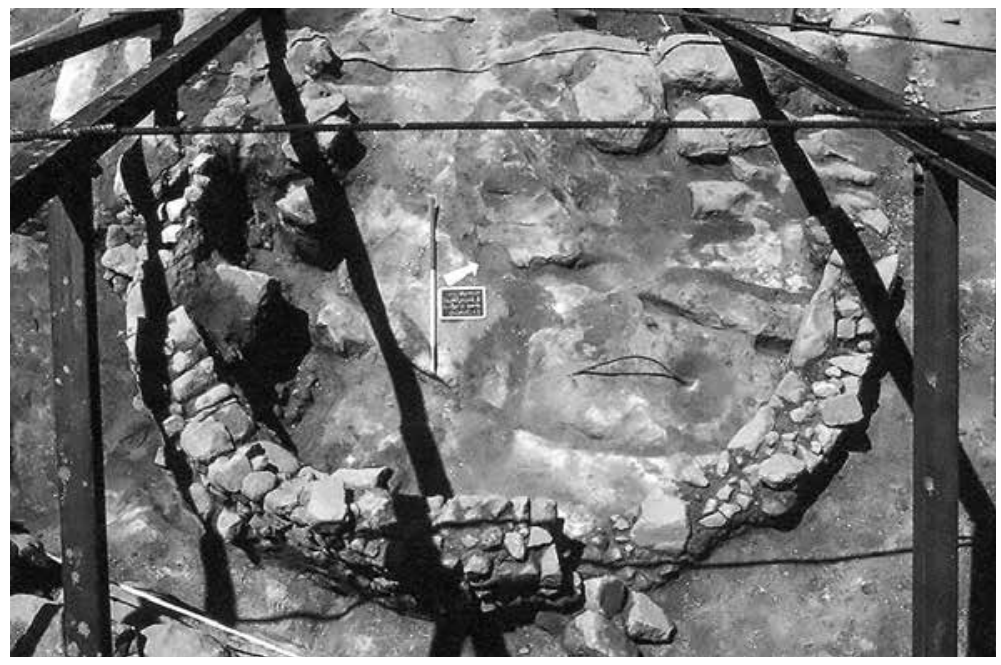

Fig. 5.

Castelo de Gaia. Construção circular da Idade do Ferro aparecida nas escavações dos terrenos da Taylor Fonseca, SA. Foto Teresa P. Carvalho/J. Fortuna.

silos, saibreiras e pisos de circulação, evidenciando por certo uma ocupação densa e com diversas fases ${ }^{33}$. Por fim, novamente quase à cota do rio Douro, numa outra intervenção ocorreram também ruínas de muito interesse, nomeadamente os restos de um grande edifício, delimitado por um muro com cerca de 20 metros de extensão, no mínimo, por $0.80 \mathrm{~m}$. de largura, compartimentado por vários muros transversais, construção que os responsáveis propõem ter sido usada entre os séculos I a. C. e II d. C.

${ }^{33}$ SOUSA \& PIEDADE, 2008. 
e para a qual sugerem um eventual uso como armazém ou entreposto comercial, considerando a presença de uma espécie de silo numa das salas e a abundância de restos de contentores cerâmicos ${ }^{34}$. Noutras sondagens foram identificados muros de outras construções, com cronologias aparentemente similares ${ }^{35}$. Em contrapartida, foram mais parcos os vestígios arquitectónicos detectados nas escavações feitas no topo da colina por A. C. Ferreira da Silva, não obstante o achado de uma construção rectangular que incluía uma lareira feita sobre base de fragmentos de ânfora ${ }^{36}$.

Datáveis já do período tardo-antigo têm também sido encontradas importantes ruínas, que elencaremos apenas de passagem por interessarem menos ao tema deste ensaio. Assim, destacamos as escavações feitas na igreja do Bom Jesus de Gaia, na encosta NE. do Castelo, sob a qual se identificaram parcialmente duas construções, caracterizadas pelo autor da escavação como «um edifício paleocristão, violentamente destruído no século VI» sobre o qual se encontrava «um edifício da Alta Idade Média, também violentamente destruído e incendiado» ${ }^{37}$. Numa plataforma a Noroeste da mesma elevação, a Quinta de Santo António, foi interrompida, por razões ligadas ao projecto imobiliário que a motivou, a escavação de um grande edifício, seguramente de natureza religiosa, associado a pelo menos uma dezena de sepulturas de diferentes tipologias e importante espólio ${ }^{38}$, intervenção arqueológica cuja conclusão e estudo poderão trazer consequências surpreendentes para o entendimento da ocupação tardo-antiga das margens do Douro, já para não falar da dimensão patrimonial, que infelizmente continua alheia aos decisores políticos e económicos locais.

$\mathrm{Na}$ margem Norte os exemplos serão porventura mais numerosos, mas sistematicamente correspondentes a intervenções em pequenas parcelas, onde os vestígios foram muito afectados pelas construções subsequentes ou as condições de segurança não admitem, segundo os responsáveis, a escavação em profundidade. Por estas razões, identificaram-se já dezenas de tramos de muros, curvilíneos ou rectilíneos, e por vezes restos de empedrados, buracos de poste e outras evidências, mas nunca logrou definir-se a planta integral de qualquer construção, sendo talvez as mais completas as que ocorreram na Rua D. Hugo, nomeadamente no $\mathrm{n}^{\circ} 5$ - onde se vêem os restos de uma casa castreja com vestíbulo e uma construção ortogonal de cantos arredondados, datada do século $\mathrm{I}^{39}$-, no no 37-39 da mesma rua, onde apareceram restos de duas casas redondas, pavimentos empedrados e outros achados de relevo ${ }^{40}$, e as diversas

\footnotetext{
${ }^{34}$ BARBOSA \& PRIETO, 2011: 42-3.

${ }^{35}$ BARBOSA \& PRIETO, 2011; SILVA et al., 2017.

${ }^{36}$ SILVA, 1984: 46; SILVA, 2007: 80, nota 485.

${ }^{37}$ GUIMARÃES, 1995a: 132-9; GUIMARÃES, 1989; GUIMARÃES, 1995 b.

${ }^{38}$ NASCIMENTO et al., 2008.

${ }^{39}$ REAL, 1984: 76-7; REAL et al., 1985-1986: 22-3; REAL \& OSÓRIO, 1993: 18-22; SILVA, 2000. Aliás, exemplo único de arqueossítio conservado e musealizado nos começos da década de 1990, situação que não parece possível de repetir-se, pela mudança das políticas patrimoniais, para achados talvez de similar interesse feitos nas imediações. ${ }^{40}$ BARBOSA, 2015.
} 


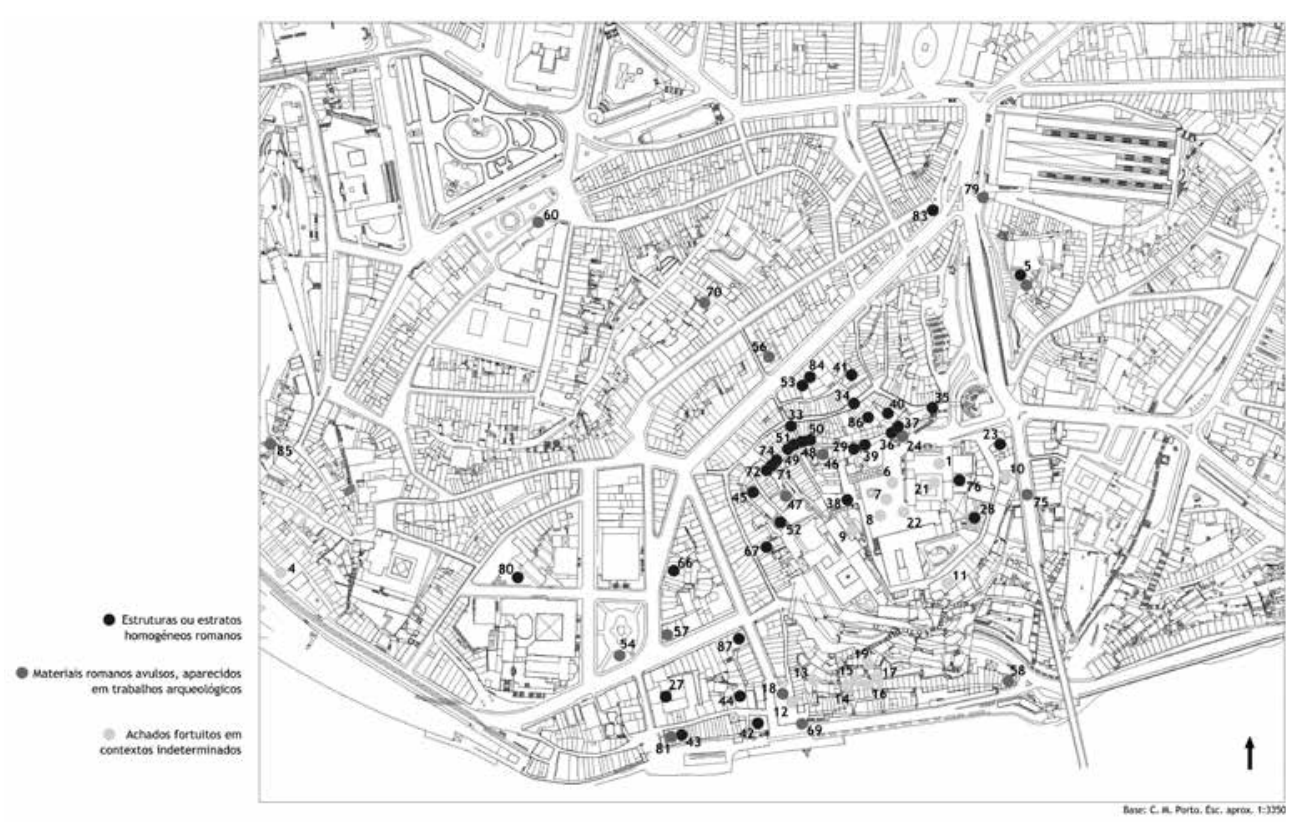

Fig. 6. Intervenções no Morro da Sé e Ribeira do Porto com vestígios romanos. Reprodução de SILVA, 2010.

sondagens feitas no espaço daquele arruamento em recentes obras de requalificação, que evidenciaram, entre outros vestígios, uma construção de planta circular, associada a um empedrado, para além de diversos muros rectilíneos, silos, buracos de poste e outros elementos ${ }^{41}$. Também nas encostas da elevação têm sido identificados vestígios da ocupação mais antiga da cidade, dispensando-se a sua enumeração por serem sensivelmente idênticos os vestígios aos localizados no topo, e por economia de espaço, tanto mais que na sua maioria se encontram inventariados ${ }^{42}$ (Fig. 6).

Estes elementos, que essencialmente nas últimas duas décadas vêm documentando cada vez mais a ocupação proto-histórica e do período romano nas elevações da Sé do Porto e do Castelo de Gaia, dificilmente permitem ainda uma perspectiva de conjunto da extensão e organização de cada um dos povoados. Por um lado pelo carácter minimalista das práticas de salvaguarda arqueológica, presentemente sem força política ou peso social para determinar trabalhos arqueológicos que além do respeito sofrível pelas leis visem efectiva procura de conhecimento; por outro, naturalmente, pelo diferenciado grau de conservação dos vestígios, do que resulta que após dezenas de sondagens e escavações arqueológicas se tenham obtido apenas umas

\footnotetext{
${ }^{41}$ MARÇAL, 2013.

42 SILVA, 2010.
} 


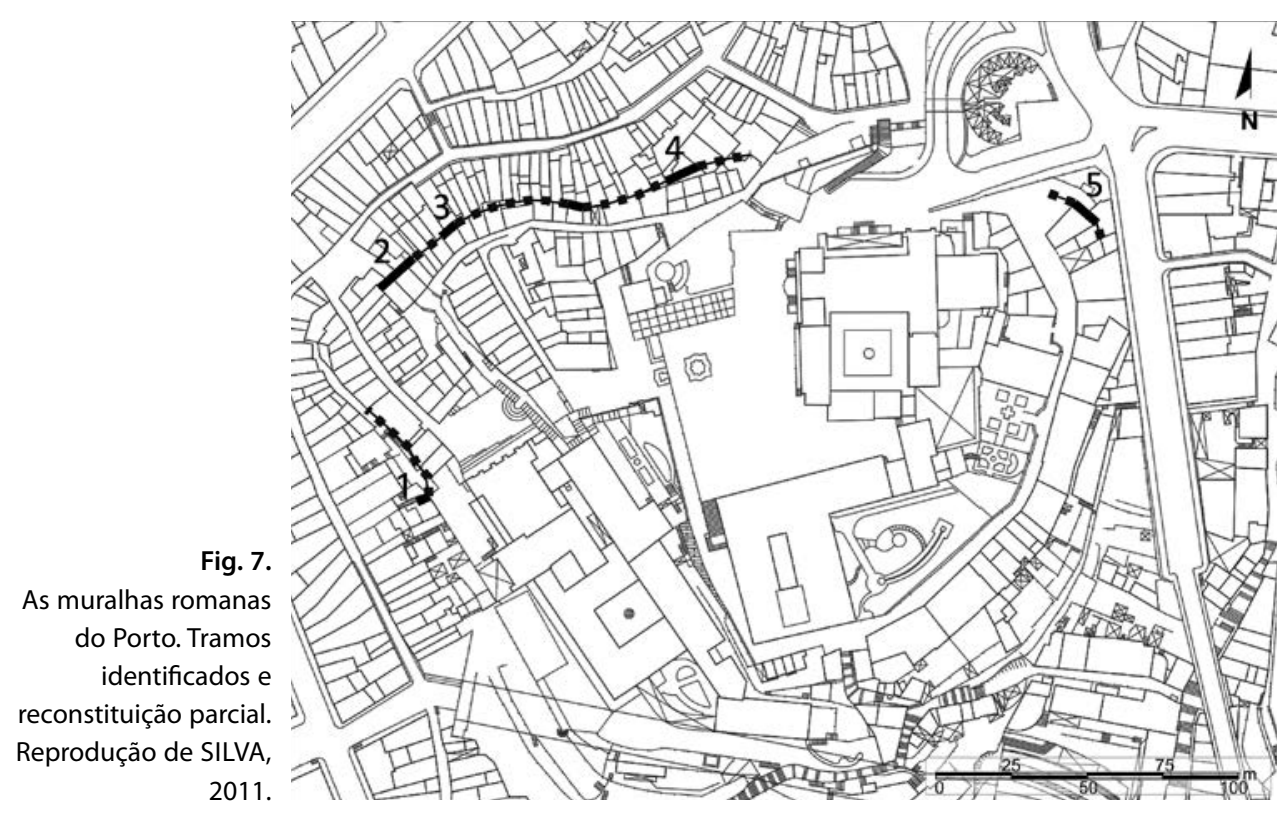

quantas plantas incompletas e muros avulsos, sem qualquer noção do sistema vial, eventuais espaços públicos ou do urbanismo dos aglomerados.

Este ponto leva-nos à consideração das muralhas que delimitavam os núcleos do morro da Sé e de Gaia. O caso portuense foi objecto de revisão recente que no geral se encontra actualizada ${ }^{43}$ (Fig. 7), pelo que bastará breve resumo da informação disponível, omitindo as situações mais duvidosas. Os troços de muros espessos que, pelo aspecto e localização, foram identificados como tramos da muralha romana da cidade ocorreram já em perto de uma dezena de pontos, subindo, a partir de Poente, do Largo do Colégio pela Rua e Largo da Penaventosa até à Rua de D. Hugo, já no topo da colina. Fruto das condicionantes físicas e das circunstâncias já enunciadas, em praticamente todos os casos as observações foram muito limitadas, impedindo a devida caracterização e datação das estruturas.

Esta muralha, cujo traçado é ainda conjectural, se bem que em largos troços fortemente sugerido pela topografia e pela evolução do edificado posterior, parece ter três fases construtivas ou de reedificação, aparentemente no mesmo ou em muito similar alinhamento. O troço mais antigo conserva-se Rua de S. Sebastião, 53-55 e apresenta 7,00 metros de extensão por 2,70 de alçado, com uma espessura original de 1,90 metros, ampliada até aos 2,50 m por um reforço ou contraforte exterior, no ponto de maior pendente da encosta norte do morro da Sé (Fig. 8); exibe aparelho

\footnotetext{
${ }^{43}$ SILVA, 2011.
} 


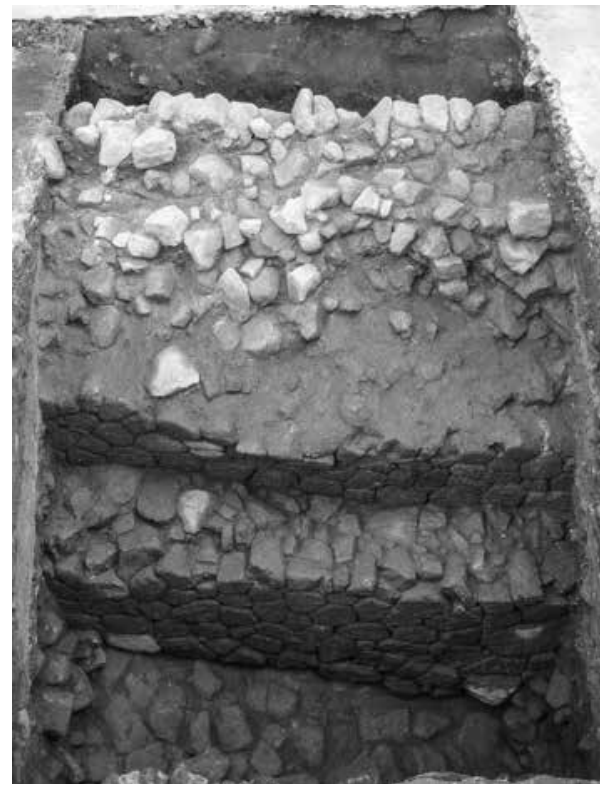

Fig. 8.

Troço de muralha pré-romana do Porto.

Foto reprod. de FONSECA; TEIXEIRA;

FONSECA 2009/Arqueologia e Património.

de tendência helicoidal, de evidente aspecto pré-romano, e foi datado pelos responsáveis da intervenção dos séculos II-I a. C. ${ }^{44}$.

Uma segunda fase parece detectar-se em vários troços mais a Poente, na Rua da Penaventosa (em especial nos números 39-43 e 25-27), e Largo da Penaventosa, n. ${ }^{\text {os }} 21$ e 25. Escavada apenas pelo tardoz e ao nível das fundações, uma vez que a fachada exterior se acha sob a parede dos edifícios actuais, a muralha não pôde ser observada na sua espessura integral, que variava entre 0,70 e 1,85 metros nas diferentes casas, sendo por isso de presumir que se aproximasse dos 2,50 metros. Se bem que os materiais arqueológicos associados fossem escassos, foi proposta uma datação global entre os meados/2. ${ }^{\text {a }}$ metade do século I e a $1^{\text {a }}$ metade do século II para a sua construção ${ }^{45}$.

Por fim, na sondagem feita na Rua da Penaventosa, 25-27 verificou-se que a cerca possuía duas fases construtivas, a primeira dos séculos I-II, como visto, e uma mais recente, aparentando ser reforço ou reformulação da primeira, atribuída hipoteticamente, pela raridade do espólio, ao século III ou IV ${ }^{46}$. Tal cronologia, a confirmar-se, pode coincidir com a datação de um outro tramo da muralha, reconhecido também pela face interna, identificado na década de 1980 na Rua D. Hugo, n. ${ }^{\circ} 5$ e para o qual se propôs uma fundação nos finais do século III $^{47}$. Cronologia

\footnotetext{
${ }^{44}$ FONSECA et al., 2009; TEIXEIRA, 2011.

${ }^{45}$ Cf. SILVA, 2011: 46-48, com referências específicas.

${ }^{46}$ SILVA, 2011: 47.

${ }^{47}$ REAL et al., 1985-1986: 19-20.
} 
idêntica - atendendo à tipologia e à circunstância de ser exterior a uma sepultura com cobertura de tegulae do século IV-V - parece poder atribuir-se à estrutura de grande aparelho em opus vittatum e com boa isodomia localizada no logradouro exterior de um prédio intervencionado no Largo do Colégio 9-1248, correspondente talvez a um torreão semicircular, porventura análogo aos das muralhas de finais do século III de Bracara Augusta ${ }^{49}$ ou da antiga Vissaium/Viseu ${ }^{50}$.

Do lado de Gaia os dados serão porventura mais claros, fruto das condições em que se identificaram as estruturas defensivas do povoado. Na já mencionada escavação da Taylor Fonseca localizou-se um troço com cerca de 45 metros de um muro com uma largura entre os 1,90 e os 2,20 metros, conservado num alçado entre 0,8 e 1,8 metros, constituído por dois paramentos em pedra de aparelho irregular, ligado por pedra miúda argamassada nas juntas e com enchimento de pedra ${ }^{51}$. A fundação desta muralha, «que seguramente envolveria todo o monte, um pouco abaixo da sua cota média [...] entre os 26 e os 27 metros», terá ocorrido, a avaliar pelos materiais arqueológicos exumados da vala de fundação interna e as camadas por ela cortadas, na primeira metade ou meados do século $\mathrm{I}^{52}$ ou já nos começos da dinastia flávia ${ }^{53}$.

Um pouco mais a Norte deste ponto e a cota levemente inferior, na mencionada escavação do antigo Hard Club, encontrou-se à cota aproximada de 20 metros um muro com 1,30 metros de largura e três fiadas de pedras de pequenas dimensões com cerca de $0,4 \mathrm{~m}$ de altura ${ }^{54}$. Está construído com dois paramentos de pedra não muito grande, com juntas preenchidas por argamassa argilosa e o interior cheio com pedra e terra, encontrando-se coberto por depósitos com materiais exclusivamente de época romana e assentando directamente «numa camada com cerâmica castreja mais tosca, alguns materiais porventura de origem púnica e sem presença de cerâmicas romanas», o que levou os responsáveis pela escavação a situar o uso da construção entre os séculos II-I a. C. e o II da nossa era $^{55}$. Os mesmos autores sugeriram tratar-se de uma muralha, mas admitindo também que o muro pudesse, tão só, servir de delimitação do espaço ocupado pelo grande edifício atrás referido ${ }^{56}$.

Voltando agora ao lado poente do Castelo, deve noticiar-se um outro achado importante a este respeito. A avaliação arqueológica prévia de um projecto imobiliário para um terreno situado no gaveto entre as ruas de Entre Quintas e de São Marcos foi feita através da escavação de diversas sondagens mecânicas que proporcionaram,

\footnotetext{
${ }^{48}$ CLETO \& VARELA, 2000; VARELA \& CLETO, 2001.

${ }^{49}$ LEMOS et al., 2001; LEMOS et al., 2007.

${ }^{50}$ CARVALHO \& CHENEY, 2007; DE MAN, 2011: 166-71.

${ }^{51}$ CARVALHO \& FORTUNA, 2000: 160; CARVALHO, 2003: 828.

${ }^{52}$ CARVALHO \& FORTUNA, 2000.

${ }^{53}$ CARVALHO, 2003: 828.

${ }^{54}$ BARBOSA \& PRIETO, 2011.

55 SILVA et al., 2017.

${ }^{56}$ BARBOSA \& PRIETO, 2011: 41.
} 


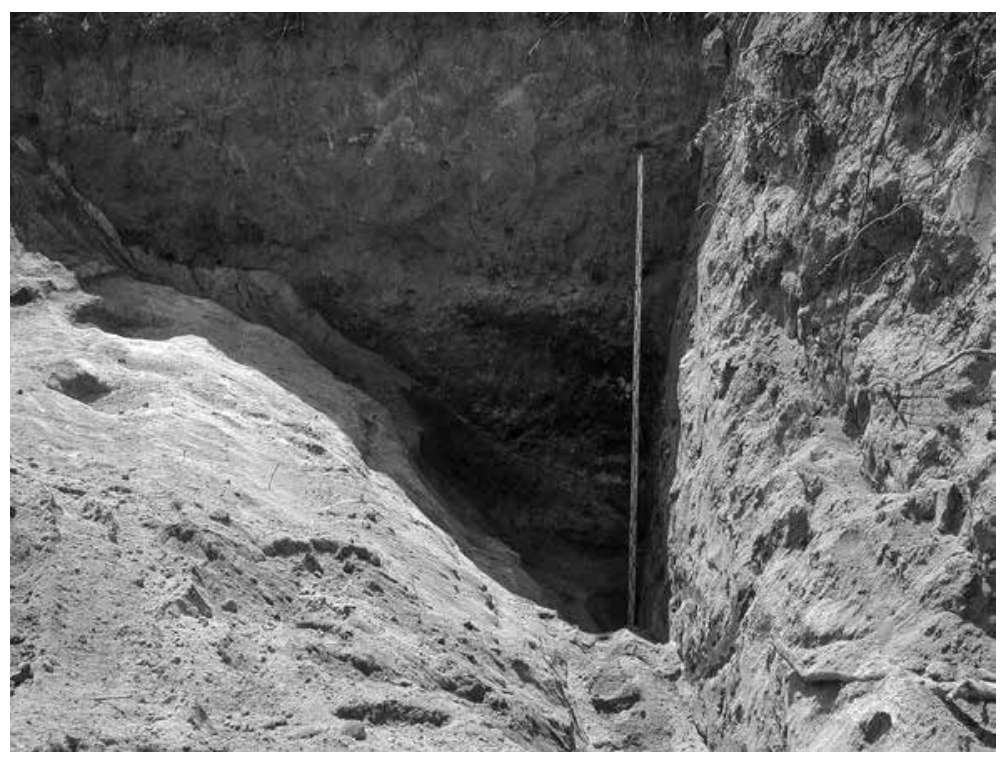

Fig. 9.

Secção do fosso exterior do Castelo de Gaia.

Foto reprod. de QUEIROGA 2006/

Perennia Monumenta.

entre materiais de diversas épocas, na sua maioria descontextualizados, elementos arquitectónicos romanos, como uma base e fuste de coluna e pedras almofadadas e mais importante - dois fossos defensivos, escavados no saibro natural e distanciados entre si cerca de 23 metros $^{57}$. Não obstante as limitações do espaço intervencionado e da metodologia adoptada, os dados recolhidos permitem estimar a largura de 6,50 - 7,00 metros e uma profundidade máxima a rondar os 3,50 - 3,70 metros para o fosso interior ${ }^{58}$, acrescentando o arqueólogo responsável a sua convicção de que estaria adossado a uma muralha, que o acompanharia pelo interior e poderá ainda conservar-se sob um muro de socalco moderno situado a cota superior ${ }^{59}$. $\mathrm{O}$ fosso externo teria também uma largura superior a 6,00 metros e profundidade idêntica ao primeiro ${ }^{60}$ (Fig. 9). A observação estratigráfica não permitiu datar a abertura dos fossos, mas o mesmo autor admite que o fosso interior, presumivelmente da Idade do Ferro, possa tenha «servido como elemento de defesa até uma fase avançada do processo de romanização» ${ }^{61}$.

Sintetizemos um pouco os dados antes de prosseguir. Os trabalhos arqueológicos dos últimos quarenta anos têm vindo a revelar a ocupação antiga das colinas, quase fronteiras, do Castelo de Gaia e do morro da Penaventosa. Em ambas se docu-

\footnotetext{
${ }^{57}$ QUEIROGA, 2006: 13-15, fig. 2.

${ }^{58}$ SILVA, 2017: 112-3.

${ }^{59}$ QUEIROGA, 2006: 14, figs. 6 e 7.

${ }^{60}$ QUEIROGA, 2006: 7-8, figs. 4 e 5.

${ }^{61}$ QUEIROGA, 2006: 7-8, figs. 4 e 5.
} 
menta a origem do povoamento entre os finais da Idade do Bronze e os começos do Ferro, sem poder precisar-se mais a cronologia por falta de datações e estudo dos materiais exumados; os dois castros prosseguiram depois a sua vida, com presumível aumento demográfico e correspondente densificação construtiva até à chegada do invasor romano.

A arqueologia tem trazido à luz do dia, de um e outro lado, os alicerces de diversas construções em pedra, de planta circular, com e sem vestíbulo, por vezes associadas a pavimentos empedrados ou em terra batida e o correspondente mobiliário artefactual, especialmente cerâmico. Pela mesma escassez de estudos e pelo facto destas construções aparecerem muitas vezes associadas a edifícios de planta ortogonal (que por vezes, todavia, se lhes sobrepõem), a imagem cronológica mais imediata é a de que ilustrarão uma fase avançada da Idade do Ferro, digamos, a partir da segunda metade do século II a. C., o que naturalmente carece de confirmação. Não se detectaram por ora num ou noutro lado - a avaliar pelos relatórios técnicos e as escassas publicações - elementos excepcionais no plano arquitectónico ou da plástica castreja, como pedras lavradas, restos escultóricos ou eventuais edifícios singulares ou de uso não doméstico.

Desconhecemos também os sistemas defensivos ou de delimitação de ambos os povoados, com excepção, no que se refere ao Porto, do troço de muralha da Rua de S. Sebastião 53-55, aparentemente tardio, ainda que o aparelho e a estratigrafia apontem para a sua natureza indígena; podendo talvez presumir-se que em certos pontos a muralha do século I-II, refeita ou ampliada no século III ou IV, possa assentar ou pelo menos conservar o traçado de um alinhamento anterior. Considerando que estes alinhamentos têm correspondência muito próxima (e em alguns casos coincidente, como na Rua da Penaventosa) com o traçado da primitiva cerca medieval, podemos estimar a superfície intra-muros do aglomerado castrejo em 3,5 ha, considerando que teria uma única linha amuralhada, naturalmente.

No castro da margem sul, a admitir-se como pertencente a uma cerca perimetral exterior o muro a cota mais inferior, e a aceitar-se a sua datação dos séculos II-I a. C., não se vislumbram outras nem efectivas muralhas proto-históricas, devendo merecer séria consideração a dupla linha de fossos (junto a presumida muralha) da encosta poente. A área do povoado indígena poderia rondar os 2,5 ha, chegando talvez aos 4 ha se considerarmos como limite a eventual cerca à cota inferior. Não há ainda qualquer estudo sistemático realizado sobre os espólios artefactuais correspondentes aos ambientes proto-históricos não romanizados, mas as cerâmicas indígenas da Idade do Ferro parecem evidenciar, sem surpresa, uma grande similitude nos povoados das duas margens, o que limita por certo o seu uso como eventual marcador cultural.

A questão do impacte da conquista romana e os efeitos que terá tido no desenvolvimento urbano destes dois castros durienses leva-nos à questão da cronologia, 
que pode discutir-se em três andamentos, o do embate inicial, o do efectivo domínio sobre o território e aquele que mais propriamente poderíamos designar como de aculturação. Parece fora de dúvida que a campanha de 137 a. C. de Decimus Iunius Brutus constituiu um elemento crucial para a integração das terras do entre Douro e Minho na órbita económica romana, estimulando as rotas de comércio atlântico ${ }^{62}$, que já há décadas os comerciantes gaditanos frequentavam, como salientaram Rui Morais e outros autores ${ }^{63}$; promovendo a exploração das áreas interiores ${ }^{64} \mathrm{e}$, para o que nos interessa particularmente, enquanto oportunidade para a chegada à História dos Callaeci ${ }^{65}$, o primeiro dos populi com que o procônsul romano se enfrentou e que terão convocado em sua ajuda outras populações do Norte, reunindo os 60.000 combatentes que no dizer de Orósio ${ }^{66}$ foram praticamente dizimados, coincidindo assim a sua apresentação étnica com o seu quase genocídio. Aliás, a sua identidade tópica terá sobrevivido pouco mais de um século, como sabiamente apontou Gerardo Pereira ${ }^{67}$, pois quando, algures pela mudança de era, na então jovem urbe de Bracara Augusta se epigrafou um monumento honorífico a um neto de Augusto, seleccionou-se, com hábil pedagogia e aparentemente sem ser caso único na cidade ${ }^{68}$, uma entidade colectiva, Callaecia, como dedicante, nada ou pouco tendo já que ver com o primitivo solar do povo ou castellum epónimos ${ }^{69}$ mas usando a praxis epigráfica como elemento de reforço da nova identidade étnico-política então em clara afirmação ${ }^{70}$.

Estamos longe de compreender o impacte físico da campanha de Bruto, quer pela ausência de vestígios de assédio aos povoados indígenas ${ }^{71}$, quer pelas alterações que neles possam ter sido efectuadas nesse contexto. A. C. Ferreira da Silva propõe que a rede hierarquizada de castros, tutelada por determinados lugares-centrais, que parece percepcionar-se nessa época terá estado relacionada com a «necessidade de uma estratégia de defesa sequente à campanha de Decimus Iunius Brutus» ${ }^{72}$, no que é seguido por Jorge de Alarcão ${ }^{73}$ e outros autores, mas precisaríamos de mais dados arqueológicos e datações absolutas para confirmar esta sugestão. Poderão

\footnotetext{
62 TRANOY, 1981: 126-132; MARTÍNEZ MERA, 2001: 304-6.

${ }^{63}$ MORAIS, 2007a; MORAIS, 2007b e, no presente volume, o estudo Douro, um rio aquém do esquecimento; NAVEIRO, 1991; GONZÁLEZ RUIBAL; 2006-2007: 512-41.

${ }^{64}$ MORILLO CERDÁN, 2016: 60.

${ }^{65}$ Não contabilizando a larga alusão de Apiano de que já o procônsul da Ulterior, Quinto Servílio Cipião, teria em 139 a. C. «arrasado os campos» dos Vetões e dos Callaicos (Iber, 70) nos últimos episódios das guerras lusitanas.

${ }^{66}$ Historiarum adversus paganos, V, 5, 12.

${ }^{67}$ PEREIRA-MENAUT, 1984: 281; PEREIRA-MENAUT, 1998: 306-7.

${ }^{68}$ REDENTOR, 2011: II, 115-6.

${ }^{69}$ TRANOY, 1981: 150; PEREIRA-MENAUT, 1984: 280; PEREIRA-MENAUT, 1998a: 303-4; REDENTOR, 2011 : II, 114-5.

${ }^{70}$ PEREIRA-MENAUT, 2010: 248.

${ }^{71}$ Se bem que este possível indicador deve ser tomado com prudência, em função das distintas estratégias e circunstâncias da conquista, como recorda Angél Morillo (MORILLO CERDÁN, 2014: 141-142).

72 SILVA, 2007: 76.

${ }^{73}$ ALARCÃO, 1993: 208.
} 
estar as muralhas «republicanas» do Porto e talvez de Gaia relacionadas com estas estratégias?

As campanhas militares seguintes - as de Públio Craso (96-94 a. C.) e sobretudo a de César (61-60 a. C. $)^{74}$ - não obstante terem o saque e não a conquista como principal motivo ${ }^{75}$, terão na verdade esbatido as últimas reacções indígenas, a ponto de nos inícios do principado de Augusto a região estar pacificada e ter até podido eventualmente servir como apoio de rectaguarda às forças em serviço nas guerras cântabras ${ }^{76}$.

Levado o Império à sua máxima extensão ocidental, organizados e distribuídos por ciuitates os principais populi, que terá acontecido aos castella de Cale e ao seu homólogo em terras dos Túrdulos? Desde há muito que navios e comerciantes de muitas paragens demandavam a foz do Douro, primeiro trazendo cerâmicas finas e vidros do Mediterrâneo oriental ${ }^{77}$, depois mercando louças e outros produtos da Bética, como amplamente se atesta pelas ânforas tardo-republicanas identificadas no Porto $^{78}$, no Castelo de Gaia ${ }^{79}$ e mais recentemente no sopé deste mesmo sítio ${ }^{80}$, mas é de crer que a mudança dos tempos e do mando se reflectisse também na organização dos aglomerados urbanos.

É neste contexto que devemos talvez encarar as muralhas que ambos os sítios terão feito erigir entre os meados do século I (Gaia) e a primeira metade do II (Porto). Analisando as muralhas das cidades hispânicas no trânsito entre a República e o Império, David Hourcade ${ }^{81}$ começa por lembrar a distinção clássica entre fortificação e cerca, considerando que além de eventuais propósitos militares (raramente atestados, aliás), a delimitação perimetral de um espaço urbano convoca todo um conjunto de sentidos e significações que é ocioso evocar; mas acaba por abandonar esta dicotomia, também por vezes traduzida no binómio securitas dignitas, para concluir que na península ibérica a fortificação das cidades, em especial no período das duas primeiras dinastias imperiais é sobretudo marca de uma nova forma de urbanização, tanto nas cidades privilegiadas como nas peregrinas, reflectindo a "poliadisation» ou seja, a adopção por parte de uma comunidade das instituições características da polis ${ }^{82}$; ou, dito de outra forma, a expressão pública

\footnotetext{
${ }^{74}$ Tendo pelo meio a equívoca tomada de Cale por Perpenna nos anos de 74 ou 73, no quadro das guerras sertorianas, segundo uma emenda renascentista a um trecho de Salústio, informação reproduzida acriticamente por muitos Autores mas encarada com justificado cepticismo por outros e que aqui não podemos detalhar, como o fizemos já noutros trabalhos (cf. SILVA, 2010: 216-7).

${ }^{75}$ MARTÍNEZ MERA, 2001: 299-301.

${ }^{76}$ MORILLO CERDÁN, 2016: 66; CENTENO et al., 2016: 78-80.

${ }^{77}$ REAL, 1984: 77-8; REAL et al., 1985-1986: 28-29; GONZÁLEZ RUIBAL, 2006-2007: 513, 524.

${ }^{78}$ MORAIS, 2013: 103-7.

${ }^{79}$ SÁ \& PAIVA, 1994.

${ }^{80}$ SILVA et al., 2017.

${ }^{81}$ HOURCADE, 2003.

${ }^{82}$ HOURCADE, 2003: 317-21.
} 
e monumental da nova iurisdictio que sanciona ou promove tal empreendimento ${ }^{83}$. Terá isto alguma a coisa a ver com a criação de ciuitates e de todo o novo ordenamento jurídico nelas implicado? Seja como for, anote-se de passagem, a ideia de que os antigos castros da Sé e de Gaia poderiam em época romana fazer parte de um mesmo aglomerado urbano, como uma cidade bicéfala, aparentemente sugerida por López Quiroga ${ }^{84}$ e outros autores deve, face a estas considerações e à própria divisão provincial, ser posta de lado.

Na verdade, se do século primeiro para o segundo da nossa era, a edificação de uma cerca pétrea, mais ou menos monumental, foi reflexo de alterações urbanísticas profundas nos dois povoados em análise, tal não é por ora de todo explícito no registo arqueológico, nem, convenhamos, sequer a topografia de ambos os sítios o favorece, sendo forçoso procurar as áreas baixas ribeirinhas para que as novas técnicas construtivas se aplicassem e os novos gostos encontrassem melhor resposta.

Os indícios de uma significativa ocupação romana na zona baixa do antigo concelho de Vila Nova e na «Ribeira» de Gaia traduzem-se por ora no achado recorrente de cerâmicas, em especial tegula e outro material de construção em diversas intervenções feitas no local; mas por vezes os terrenos encontram-se perturbados por construções posteriores ou por efeito das cheias do Douro, e como causa maior desta lacuna de informação devemos sempre apontar a falta de trabalhos arqueológicos na zona, seja por intuito de investigação, seja mesmo nos casos em são legalmente obrigatórios em projectos imobiliários localizados em áreas classificadas.

Na margem Norte o panorama é bem diferente, em especial como resultado dos trabalhos arqueológicos efectuados durante uma década no Arquivo Histórico Municipal/Casa do Infante, onde foram postos à vista os restos de um edifício tardo-romano de grandes dimensões e, para já, os únicos pavimentos em mosaico da cidade $^{85}$ (Fig. 10). Muitas outras sondagens e trabalhos de acompanhamento têm revelado vestígios móveis e imóveis da ocupação romana, se bem que os muros estejam ordinariamente truncados e os dados careçam da falta de estudo e publicação que já se apontou. Todavia, em duas intervenções de larga escala feitas nos últimos anos para a instalação de uma unidade hoteleira, para Nascente e no mesmo quarteirão da Casa do Infante, apareceram também ruínas de significativa expressão, que não permitem por enquanto a reconstituição de plantas integrais mas obedecem à mesma orientação e alinhamento da domus urbana da Casa do Infante ${ }^{86}$, elemento

\footnotetext{
${ }^{83}$ DOPICO CAÍNZOS, 2009: 45; DOPICO CAÍNZOS, 2013: 95; DOPICO CAÍNZOS \& SANTOS, 2012: 587, 595.

${ }^{84}$ LÓPEZ QUIROGA, 2004: 93.

85 TEIXEIRA \& DORDIO, 2000; GOMES, 2011; SILVA, 2010: 222-3.

${ }^{86}$ Referimo-nos às intervenções arqueológicas realizadas para a construção do Hotel Carris (TEIXEIRA, 2011; TEIXEIRA, 2015) e sua ampliação recente (NOGUEIRA et al., 2018).
} 
Fig. 10.

Ruínas romanas e pavimento em mosaico

(réplica) da Casa do Infante, Porto. Foto do Autor.

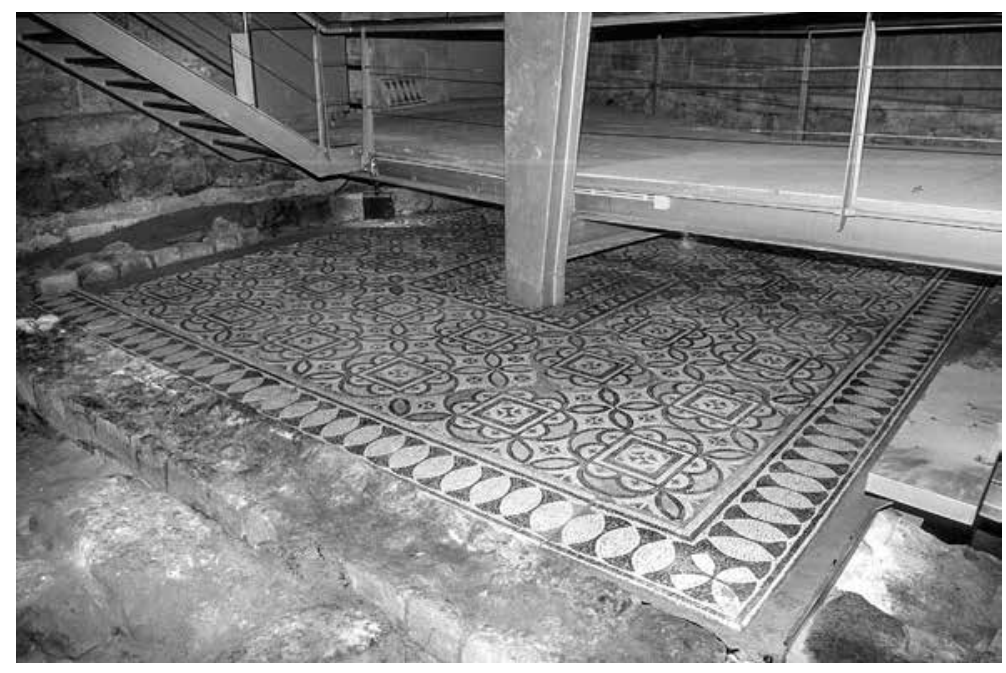

essencial por traduzir um urbanismo planificado e estruturado por eixos viários de um modo que certamente não seria possível no morro da Sé.

A cronologia deste bairro ou uicus ribeirinho ${ }^{87}$, aqui como em Gaia, é questão essencial, mas apenas na margem Norte dispomos de alguns dados, sendo evidente numa primeira análise uma ocupação muito centrada no Baixo-Império, como é claro na Casa do Infante ${ }^{88}$. A estruturação urbana desta parte baixa do povoado terá naturalmente implicado a construção de certos equipamentos públicos, tendo vindo a ser recuperadas informações históricas dispersas que sugerem a localização de uma zona termal e uma área aberta respeitante se não a um forum monumental, pelo menos talvez a uma área comercial e de outras funções colectivas ${ }^{89}$, elementos aos quais a arqueologia não deu por enquanto qualquer suporte.

Todas as cidades, fossem ou não capital de ciuitas, estruturavam-se num território e numa rede de recursos e interacções. Não é possível a este respeito reunir muitas informações para a área de Vila Nova de Gaia, mas a grande quantidade de trabalhos arqueológicos feitos na cidade do Porto nas últimas décadas permite já percepcionar todo um conjunto de "sítios" habitados durante o período romano, quer ao longo do rio Douro, quer mais para o interior ${ }^{90}$, questão que deixamos apenas em nota para ulterior discussão.

Repartidas entre Turduli Veteres e Callaici, as duas margens da foz do Douro aguardam ainda que a arqueologia ilumine o que as escassas e ambíguas fontes

\footnotetext{
${ }^{87}$ REDENTOR, 2014.

${ }^{88}$ GOMES, 2011: 838 .

${ }^{89}$ REAL \& SILVA, no prelo.

90 SILVA, 2010.
} 
documentais deixaram à especulação quase teórica. Após três décadas de trabalhos arqueológicos em número crescente, importantes restos do passado romano e pré-romano da região aguardam estudo, sistematização e o levantamento de novas hipóteses interpretativas, via que parece ser a melhor, senão a única, para compreender melhor a natureza e identidade dos limites destas duas regiões etno-históricas que foram as criações romanas da Lusitânia e da Galécia.

\section{BIBLIOGRAFIA}

AFONSO; José A.; CAMPOS; Ernesto; GUIMARÃES, Joaquim A. G.; PEDROSA, António S.; PEDROSA, Fantina T.; TAVARES, Joaquim D.; VALENTE, António M. (1989) - Plano de Pormenor do Castelo de Gaia. Inventário geral. Vila Nova de Gaia: Gab. História e Arqueologia de V. N. Gaia. Texto datilog. 2 vols.

ALARCÃO, Jorge de (1993) - Las Ciudades Romanas de Portugal. In BENDALA GALÁN, Manuel, dir. - La Ciudad Hispanorromana. Barcelona: Ministerio de Cultura/Àmbit, p. 206-223.

(1995-96) - As Civitates do Norte de Portugal. "Cadernos de Arqueologia», 12-13. Braga, p. 25-30. (1999) - Populi, Castella e Gentilitates. «Revista de Guimarães». Vol. especial [Actas do Congresso de Proto-história europeia, I). Guimarães, p. 133-50.

(2005) - Notas de arqueologia, epigrafia e toponímia - III. «Revista Portuguesa de Arqueologia», vol. 8, n. ${ }^{\circ}$ 2. Lisboa, p. 293-311.

BARBOSA, João P. (2015) - Rua D. Hugo, 37-39, Sé, Porto [...]. Informação preliminar. Porto: Logiark. Texto dactilog.

BARBOSA, João P.; PRIETO, Roger (2011) - Rei Ramiro Terraces (RRT08). Sondagens de avaliação prévia. Rua do Rei Ramiro/Cais de Gaia. Santa Marinha. Vila Nova de Gaia. Relatório Final. Porto: Logiark. Serviços Arqueológicos. Relatório dactilog.

CARVALHO, Pedro S.; CHENEY, António (2007) - A muralha romana de Viseu. A descoberta arqueológica. In Rodriguez Colmenero, A.; Rodá de Llanza, I., eds. - Murallas de Ciudades Romanas en el Occidente del Imperio (Lvcvs Avgvsti como paradigma). Actas del Congreso Internacional celebrado en Lugo... Lugo: Museo e Diputación Provincial, p. 729-45.

CARVALHO, Teresa P. (2003) - As ocupações no Castelo de Gaia - problemas de arqueologia urbana. «Revista da Faculdade de Letras - Ciências e Técnicas do Património» vol. 2. Porto, p. 823-41.

CARVALHO, Teresa P.; FORTUNA, Jorge (2000) - Muralha romana descoberta no Castelo de Gaia. «Al-Madan», 9. Almada, p. 158-62.

CENTENO, Rui; MORAIS, Rui; BARTOLOMÉ ABRAIRA, Roberto (2016) - Problemáticas e perspectivas sobre a presença militar no Noroeste hispânico no tempo de Augusto: o castro de Alvarelhos. In MORAIS, Rui; BANDEIRA, M.; SOUSA, M. J., eds. - Celebração do Bimilenário de Augusto. Ad Nationes. Ethnous Kallaikon. Braga: Câmara Municipal, p. 74-82.

CLETO, Joel A.; VARELA, José M. (2000) - Largo do Colégio, 9-12: entre a muralha romana e a românica?. «Al-madan», 2. ${ }^{a}$ Série, 9, Almada, p. 133-5.

DE MAN, Adriaan (2011) - Defesas urbanas tardias da Lusitânia. Mérida: MNAR.

DIAS, Lino Tavares (2016) - Baião, em torno do ano zero. Baião: Câmara Municipal.

DOPICO CAÍNZOS, M. Dolores (2009) - As transformacións dos pobos do noroeste hispánico na época de Augusto: a evidencia epigráfica. In DOPICO, Dolores; VILLANUEVA, M.; RODRÍGUEZ, P., eds. - Do Castro à Cidade. A romanización na Gallaecia e na Hispania indoeuropea. Actas do Curso de actualización sobre a romanización de Galiza. Lugo: Deputación de Lugo, p. 31-53. 
(2013) - Nuevas formas de administración, nuevas formas de control: la fundación de Lucus Augusti y su conventos. «Portvgalia». Nova Série, 34. Porto, p. 83-100.

DOPICO CAÍNZOS, M. Dolores; SANTOS YANGUAS, Juan (2012) - La adecuación de las entidades indígenas a la nueva administración romana: el ejemplo de los conventvs del noroeste peninsular. In SANTOS YANGUAS, Juan; CRUZ ANDREOTTI, Gonzalo, eds. - Romanización, fronteras y etnias en la Roma antigua: el caso hispano [Rev. Hist. Ant., VII]. Vitoria: Universidad del Pais Vasco, p. 581-600.

FONSECA, Jorge; TEIXEIRA, Ricardo; FONSECA, Vítor (2009) - Relatório de Progresso. Quarteirão da Bainharia. Sé. Porto: Arqueologia \& Património. Texto dactilog.

FUMADÓ ORTEGA, Iván (2013) - Oppidum. Reflexiones acerca de los usos antíguos y modernos de um término urbano. «SPAL», 22. Sevilha, p. 173-84.

GOMES, Paulo D. (2011) - Os Mosaicos da Casa do Infante e o contexto urbano na zona ribeirinha do Porto. In O mosaico romano nos centros e nas periferias : originalidades, influências e identidades : actas do X Colóquio Internacional da Associação Internacional para o Estudo do Mosaico Antigo (AIEMA), Museu Monográfico de Conimbriga [...] 2005. Lisboa: Instituto dos Museus e da Conservação.

GONZÁLEZ RUIBAL, Alfredo (2006-2007) - Galaicos. Poder y comunidad en el Noroeste de la Península Ibérica (1200 a.C - 50 d.C.). «Brigantium», 18, 19. A Coruña.

GUERRA, Amílcar (1998) - Nomes pré-romanos de povos e lugares do Ocidente Peninsular. Lisboa: Faculdade de Letras da Universidade de Lisboa. Tese de Doutoramento.

GUIMARÃES, Joaquim A. G. (1989) - Escavações arqueológicas na Igreja do Bom Jesus de Gaia. «Boletim da Associação Cultural Amigos de Gaia», 28. V. N. Gaia, p. 17-25.

(1995a) - Gaia e Vila Nova na Idade Média. Arqueologia de uma área ribeirinha. Porto: Univ. Portucalense.

(1995b) - Escavações arqueológicas na Igreja de Gaia. In Actas da IV Reunió d'Arqueologia Cristiana Hispânica (Lisboa, 1992). Barcelona: Institut d'Estudis Catalans/Univ. Nova de Lisboa, p. 429-41.

HOURCADE, David (2003) - Les murailles des villes romaines de l'Hispanie republicaine et augustéene: enceintes ou fortifications du territoire urbain? In MORILLO, Angél; CADIOU, F.; HOURCADE, D., eds. - Defensa y Territorio en Hispania de los Escipiones a Augusto (espácios urbanos y rurales, municipales y provinciales). León: Universidad de León, p. 295-324.

HÜBNER, Emílio (1871) - Noticias archeologicas de Portugal. Lisboa: Academia das Ciências.

LEMOS, Francisco S.; LEITE, José M.; CUNHA, Armandino (2007) - A muralha romana (BaixoImpério) de Bracara Augusta. In Rodriguez Colmenero, A.; Rodá de Llanza, I., eds. - Murallas de Ciudades Romanas en el Occidente del Imperio (Lvcvs Avgvsti como paradigma). Actas del Congreso Internacional celebrado en Lugo... Lugo: Museo e Diputación Provincial, p. 327-41.

LEMOS, Francisco S.; LEITE, José M.; FONTES, Luis O. (2001) - A muralha de Bracara Augusta e a cerca medieval de Braga. In FERNANDES, Isabel F., coord. - Mil Anos de Fortificações na Península Ibérica e no Magreb (500-1500): Actas do Simpósio Internacional sobre Castelos. Lisboa: Colibri/C. M. Palmela, p. 121-32.

LÓPEZ QUIROGA, Jorge (2004) - El final de la Antigüedad en la Gallaecia: La transformación de las estructuras de poblamiento entre Miño y Duero (Siglos V al X). [S.l.]: Fund. Pedro Barrié de la Maza.

MANTAS, Vasco G. (1996) - A rede viária romana da faixa atlântica entre Lisboa e Braga. Coimbra. Tese de Doutoramento apresentada à Faculdade de Letras da Universidade de Coimbra.

MARÇAL, Helena (2013) - Tipologias de ocupação da Rua D. Hugo (Morro da Sé, Porto). «Oppidum Revista de Arqueologia, História e Património», 6 (2012-2013). Lousada, p. 77-88.

MARTÍNEZ MERA, Josefa (2001) - Expediciones militares a Gallaecia na época republicana. «Gallaecia», 20. Santiago de Compostela, p. 297-316. 
MORAIS, Rui (2007a) - A via atlântica e o contributo de Gádir nas campanhas romanas na fachada noroeste da península. «Humanitas», 58. Coimbra, p. 99-132.

(2007b) - Contributo para o estudo da Economia na Lusitânia romana. «Saguntum», 39. Valência, p. 133-140.

- (2013) - Durius e Leça: dois percursos de um mesmo itinerário - problemáticas em torno das ânforas Haltern 70. «Portvgalia». Nova série, 34. Porto, p. 101-136.

MORILLO CERDÁN, Angél (2014) - Arqueología de la conquista del Norte peninsular. Nuevas interpretaciones sobre las campañas del 26-25 a.C. In CADIOU, F.; NAVARRO CABALLERO, M., eds.- La guerre et ses traces. Conflits et sociétés en Hispanie à l'époque de la conquête romaine (III ${ }^{e} I^{e r}$ s. a.C.). Bordeaux: Ausonius Éditions, p. 133-148.

(2016) - El território galaico durante las guerras cântabras: nuevas perspectivas. In MORAIS, Rui; BANDEIRA, M.; SOUSA, M. J., eds. - Celebração do Bimilenário de Augusto. Ad Nationes. Ethnous Kallaikon. Braga: Câmara Municipal, p. 54-72.

MURPHY, James (1795) - Travels in Portugal, through the provinces of Entre Douro e Minho, Beira, Estremadura (...). London: A. Strahan, and T. Cadell Jun. and W. Davies.

NASCIMENTO, André; SOUSA, Laura; SILVA, Nuno (2008) - Intervenção Arqueológica QSAVNG.07 - Quinta de Santo António - Santa Marinha, Vila Nova de Gaia - Relatório de Progresso, 2. ${ }^{a}$ e 3. ${ }^{a}$ Fases. Vila Nova de Gaia: Empatia - Arqueologia, Lda. Texto datilog.

NAVEIRO LÓPEZ, Juan L. (1991) - El comercio antíguo en el NW. peninsular. Lectura histórica del registro arqueológico. A Coruña: Museo Arqueolóxico e Histórico.

NOGUEIRA; Sandra; LEMOS, Paulo A. P.; COSTA, Rita; SILVA, João (2018) - Ampliação do Hotel Carris da Ribeira, Porto. Resultados Preliminares dos Trabalhos Arqueológicos. In HERNÁNDEZ GUTIÉRREZ, Noelia; LARRAZABAL HERNÁNDEZ, Rodrigo, coord. - Arqueología en el Valle del Duero: del Paleolítico a la Edad Media 6 - Actas de las VI Jornadas de Arqueología del Valle del Duero (Oporto, 2016). Valladolid: Glyphos Publicaciones, p. 428-438.

PEREIRA-MENAUT, Gerardo (1984) - La formación histórica de los pueblos del Norte de Hispania: el caso de Gallaecia como paradigma. «Veleia», 1. Vitoria, p. 271-87.

(1998a) - Los Galaicos. In RODRÍGUEZ NEILA, Juan F.; NAVARRO SANTANA, F., eds.- Los Pueblos Prerromanos del Norte de Hispania: una transición cultural como debate histórico. Pamplona: EUNSA, p. 301-24.

(1998b) - Reflexións en clave histórica sobre Monte Mozinho. In SOEIRO, Teresa, coord. - Monte Mozinho, 25 anos de trabalhos arqueológicos. Penafiel: Museu Municipal, 37-50.

- (2010) - El moderno debate sobre la Romanización. «Veleia», 27. Vitoria, p. 239-53.

QUEIROGA, Francisco R. [2006] - Relatório de trabalhos arqueológicos. Loteamento do Gaveto Entre Quintas-S. Marcos. Sta. Marinha, Vila Nova de Gaia. Vila Nova de Famalicão: Perennia Monumenta. Texto datilog.

REDENTOR, Armando (2011) - A cultura epigráfica no Conventvs Bracaravgvstanvs (Pars Occidentalis). Percursos pela sociedade brácara da época romana. Coimbra: Faculdade de Letras da Universidade de Coimbra. Tese de Doutoramento.

(2014) - Cale: un puerto de la Callaecia meridional. In ECK, Werner; FUNKE, Peter, eds. Öffentlichkeit - Monument - Text. XIV Congressus Internationalis Epigraphiae Graecae et Latinae - Akten. Berlin: de Gruyter, p. 443-5.

REAL, Manuel L. (1984) - Arqueologia portuense em 1984. Notícia sobre as operações de salvamento no morro da Sé, em áreas de intervenção do CRUARB. «Arqueologia», 10, Porto, p. 75-9.

REAL, Manuel L.; OSÓRIO, Maria I. P. (1993) - A Cidade: lugares primeiros. Rua D. Hugo, no 5 . In OSÓRIO, Maria I. P., coord. - O Porto das Mil Idades. Arqueologia na Cidade. Porto: Câmara Municipal, p. 15-24. 
REAL, Manuel L.; SILVA, António Manuel S. P. [no prelo] - Portumcalem Castrum Novum na época sueva. In: In Tempore Sueborum (Exposición, Ourense, 15 dic. 2017 - 4 mar. 2018). Volume de textos suplementar.

REAL, Manuel L.; TÁVORA, M. J.; OSÓRIO, M. I.; TEIXEIRA, F. (1985-1986) - Escavações arqueológicas no Morro da Sé. «Boletim Cultural da C. M. Porto», 2a Série (3/4). Porto, p. 7-60.

RODRIGUEZ COLMENERO, António (1997) - Aqua Flaviex. I. Fontes epigráficas da Gallæcia meridional Interior. $2^{\mathrm{a}}$ ed. Chaves: Câmara Municipal.

RODRIGUEZ COLMENERO, Antonio; FERRER SIERRA, Santiago (2014) - La ruta marítima atlántica de época romana: Entre Cale (Porto), Brigantium (Golfo Ártabro) y Oiassó (Irún). In ALONSO TRONCOSO, Victor; RODRÍGUEZ COLMENERO, A.; GOY DIZ, A., eds. - El Golfo Ártabro. Fragmentos de historia litoral y património. A Coruña: Universidade da Coruña, p. 209-335.

ROLDAN HERVÁS, José M. (1966) - Sobre los acusativos com «ad» en el Itinerario de Antonino. «Zephyrus», 17. Salamanca, 109-19.

(1975) - Itineraria Hispana. Fuentes antiguas para el estudio de las vías romanas en la Península Ibérica. Madrid: Univ. Valladolid/Univ. Granada.

SÁ, Manuel M. Alves; PAIVA, Maria Belém C. (1994) - Notas sobre o comércio romano na bacia do Douro. As ânforas do Castelo de Gaia e Monte Murado. «Gaya», 6 (1988-1994). Vila Nova de Gaia, p. 89-106.

SILVA, António Manuel S. P. (1994) - Proto-história e Romanização no Entre Douro e Vouga Litoral. Elementos para uma avaliação crítica. Porto. Dissertação de mestrado apresentada à Faculdade de Letras da Universidade do Porto.

(2000) - Rua D. Hugo, 5 - um arqueossítio fundador. «Al-Madan», 2. ${ }^{a}$ Série, 9, Almada, p. 136-7. (2010) - Ocupação da época romana na cidade do Porto. Ponto de situação e perspectivas de pesquisa. «Gallaecia», 29. Santiago de Compostela, p. 213-62.

(2011) - As muralhas romanas do Porto: um balanço arqueológico. «Portvgalia», Nova Série, 31-32 (2010-2011). Porto, p. 43-64.

(2017) - As construções do lugar. História(s) e Arqueologia(s) do Centro Histórico de Gaia. In SILVA, António Manuel S. P., coord. - Cidades de Rio e Vinho. Memória, Património, Reabilitação. Conferência internacional de Vila Nova de Gaia, 2015. Vila Nova de Gaia/Porto: Gaiurb, EEM/ Afrontamento, p. 100-37.

SILVA, António Manuel S. P.; MORAIS, Rui; PINA-BURÓN, Maria R.; PRIETO DE LA TORRE, Roger (2017) - Cerâmica romana importada na foz do Douro: uma escavação arqueológica no Castelo de Gaia (V. N. Gaia, Norte de Portugal). In ROSAS, Lúcia; SOUSA, Ana Cristina; BARREIRA, Hugo, coord.- Genius Loci: Lugares e Significados. Porto: CITCEM, vol. II, p. 315-331.

SILVA, Armando C. F. (1984) - Aspectos da proto-história e romanização no concelho de Vila Nova de Gaia e problemática do seu povoamento. «Gaya», 2, V. N. Gaia, p. 39-58.

(1994) - Origens do Porto. In RAMOS, Luís O., dir. - História do Porto. Porto: Porto Editora, p. 46-117.

(1996) - A cultura castreja no Norte de Portugal: integração no mundo romano. In FERNÁNDEZ OCHOA, Carmén, dir. - Los Finisterres Atlánticos en la Antigüedad. Época Prerromana y Romana (Coloquio Internacional). Madrid: Ayunt. Gijón/Electa España, p. 49-55.

(1999) - A ocupação do território do Noroeste peninsular aquando da chegada dos Romanos. In DIAS, Lino T.; ARAÚJO, Jorge, coord. - Actas da Mesa Redonda Emergência e Desenvolvimento das Cidades Romanas no Norte da Península Ibérica. Porto: Escola Prof. Arqueologia/IPPAR, p. 39-52. (2000) - Proto-história e romanização do Porto. «Al-Madan», 2a Série, 9, Almada, p. 94-103.

(2007) - A Cultura Castreja no Noroeste de Portugal. 2. a ed. rev. e actualiz. Paços de Ferreira: Câmara Municipal [ed. original 1986]. 
(2013) - A ocupação do espaço e a modelação da paisagem proto-histórica no norte de Portugal. «Brathair - Revista de Estudos Celtas e Germânicos», 13 (2). São Luís [Maranhão], p. 22-51. Publicação digital disponível em http://ppg.revistas.uema.br/index.php/brathair/index (2015) - As origens de Gaia e questões de identidade. Arqueologia e epigrafia dos Turduli Veteres. «Estudos do Quaternário», 13. Braga, p. 68-74.

SOARES, Torquato S. (1962) - Reflexões sobre a origem e a formação de Portugal. Coimbra: Faculdade de Letras, tomo I.

SOUSA, Laura C. P.; PIEDADE, Marta (2008) - Intervenção Arqueológica QSM-VNG.07/08 - Quinta de São Marcos - Santa Marinha, Vila Nova de Gaia. Vila Nova de Gaia: Empatia Arqueologia. Texto datilog.

TEIXEIRA, Ricardo (2011) - Aljube eclesiástico, muralha castreja, rua de S. Sebastião 53-55. In DELGADO, A.; VALENÇA, P.; GUIMARÃES, M., coord. - Morro da Sé de porta a porta. Porto: Porto Vivo, SRU, p. 50.

TEIXEIRA, Ricardo; DORDIO, Paulo (2000) - Intervenção arqueológica na Casa do Infante: dezassete

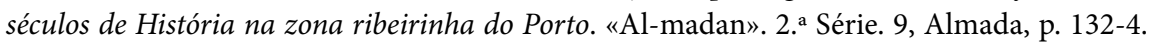

TEIXEIRA, Sofia A. S. (2011) - INF9.09. Intervenção efectuada no âmbito da construção do Hotel Carris - Ribeira, Porto. Intervenção arqueológica nos Edifícios B e C. Relatório de Progresso. Ed. A. Texto dactilog.

(2015) - Relatório preliminar da intervenção arqueológica. Imóveis sitos na Rua Infante D. Henrique, $n .^{\circ} 1-15$ e na Rua de São João, $n .^{\circ} 1$-39. Porto: Ed. A. Texto dactilog.

TRANOY, Alain (1981) - La Galice Romaine. Recherches sur le nord-ouest de la péninsule ibérique dans l'Antiquité. Paris: Diff. de Boccard.

UNTERMANN, Jürgen (1993) - Anotaciones al estudio de las lenguas prerromanas del noroeste de la Península Ibérica (1). In VV.AA - Galicia: da romanidade á xermanización. Problemas históricos e culturais. Santiago de Compostela: Museo do Pobo Galego, p. 367-97.

VARELA, José M.; CLETO, Joel A. (2001) - Intervenção arqueológica no edifício do Largo do Colégio, n. ${ }^{\circ}$ 9-12 (Freguesia da Sé, Porto). Relatório dos trabalhos realizados. Porto: [s.n.] Texto dactilografado. 



\title{
SUPERPOSICIÓN DE NUMANCIAS
}

\author{
ALFREDO JIMENO MARTÍNEZ*
}

\section{NUMANCIA Y SU ENTORNO}

Numancia ocupa el elevado y extenso cerro de La Muela, desde el que se domina estratégicamente una amplia llanura, limitada semicircularmente por las altas elevaciones del Sistema Ibérico, desde las Sierras de Urbión por occidente, pasando por las de Cebollera hasta las cimas del Moncayo al oriente, por encima de los $2000 \mathrm{~m}$ de altura. La llanura numantina está atravesada por el río Duero, que en su curso alto, y con un régimen de montaña, se ve alimentado por numerosos afluentes y arroyos que deben en gran medida su caudal a la nieve y al deshielo de los altos valles forestales y ganaderos de la sierra norte.

El cerro numantino se eleva en sucesivos escalonamientos. El altozano ofrece una dilatada cumbre, de forma almendrada, de 500 metros de norte a sur y 260 metros de este a oeste. El río Duero, por occidente, y el Merdancho, más modesto, por el sureste, abrazan a Numancia, proporcionándole con sus fosos naturales aislamiento y protección. Su posición estratégica hay que relacionarla, además, con el control del vado, en el punto donde se juntan los ríos Duero y Tera, y donde confluyen los caminos radiales del circo montañoso de la Serranía Norte que comunican el Alto Duero con el valle medio del Ebro.

* Director del Plan de Investigación de Numancia (jcyl); Departamento de Prehistoria, Universidad Complutense de Madrid. 


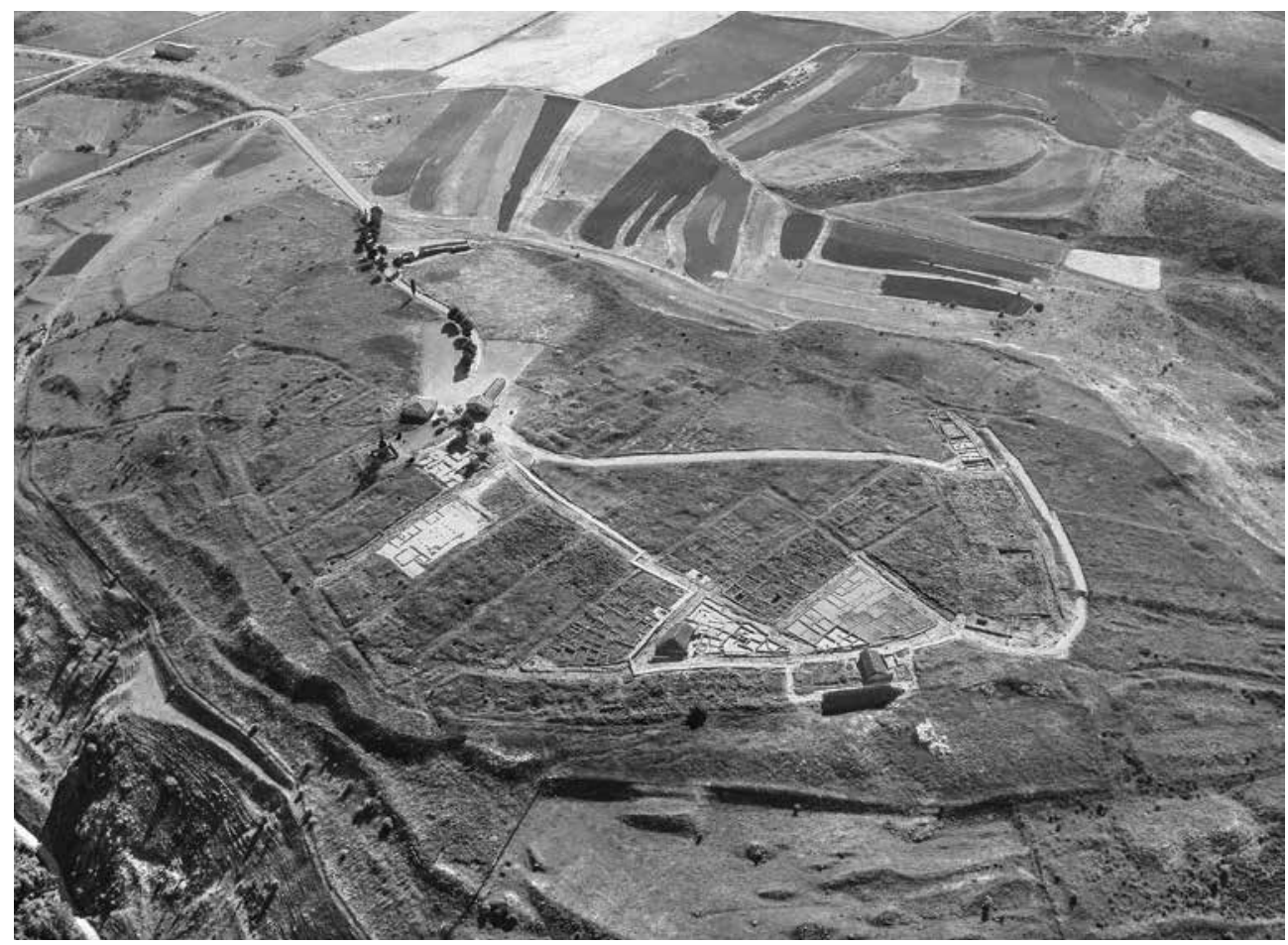

Fig. 1. Vista aérea de Numancia.

Apiano ${ }^{1}$ comenta que la ciudad «estaba rodeada de espesos bosques» y que el río Duero era navegable, ya que era remontado por los mercaderes «en pequeños esquifes $[\ldots]$ con ayuda de velas», para transportar vino y cereal. Estaba también la ciudad rodeada de zonas lagunares y pantanosas, todavía reflejadas en la existencia de pequeños encharcamientos en la zona endorreica próxima y constatada por la toponimia, que avalan las noticias de Apiano sobre la dificultad que tuvo Escipión para trazar el cerco por la zona noreste de Numancia, donde hubo una amplia laguna de unos $800 \mathrm{~m}$. de largo, desecada en el siglo XIX (Fig. 1).

\section{SUPERSICIÓN DE CIUDADES}

La Comisión de Excavaciones (1906-1923), que excavó una amplia superficie de la ciudad, unas 7 ha., informa con cierta imprecisión del trazado y organización de dos ciudades, considerando la inferior celtibérica y la superior romana. Ahora sabemos que estas supuestas dos ciudades se corresponden con dos momentos o fases de una misma ciudad romana imperial (Figs. 2 y 3 ).

${ }^{1}$ Iber, 91 . 


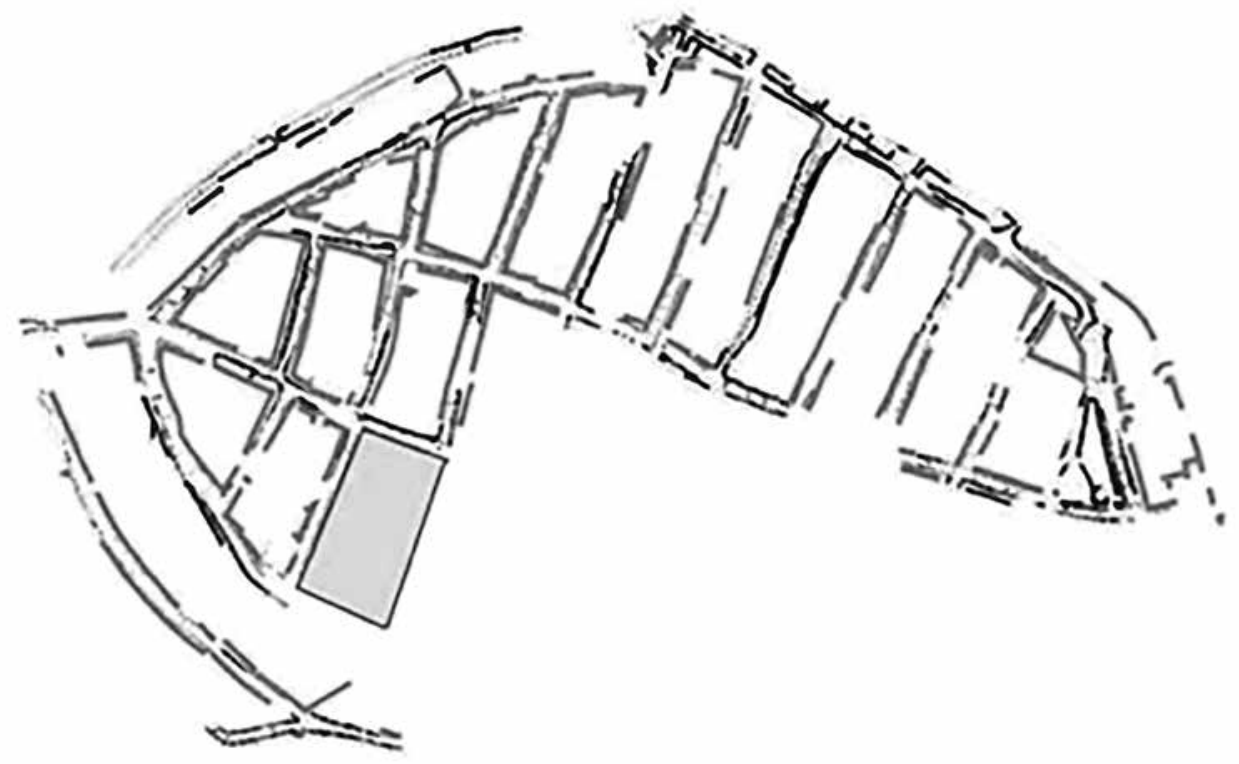

Fig. 2. Según la Comisión de Excavaciones, la urbanística en rojo sería la ciudad romana y en gris la celtibérica (1906-1923).

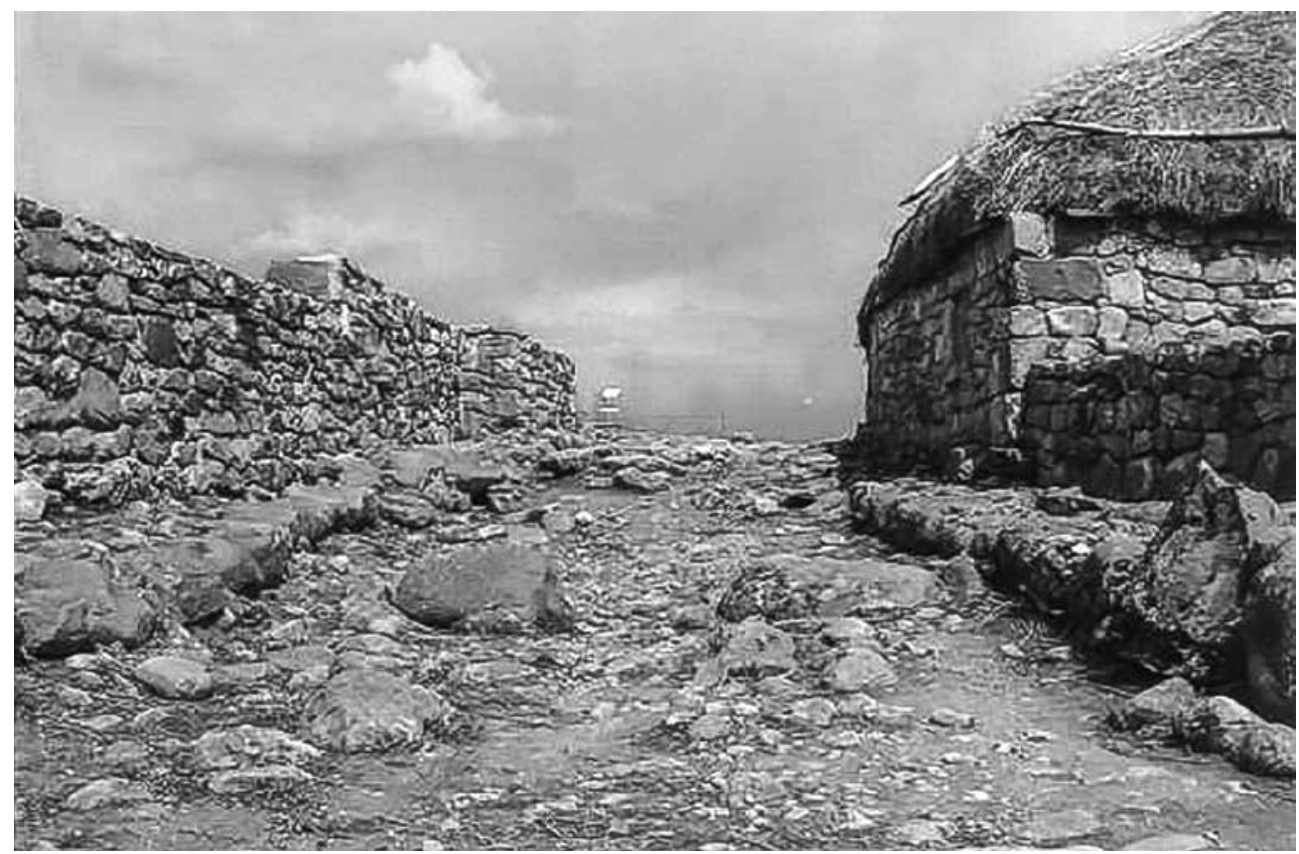

Fig. 3. La calles con piedras pasaderas serían de la ciudad celtibérica (según La Comisión de Excavaciones, 1906-1923). 


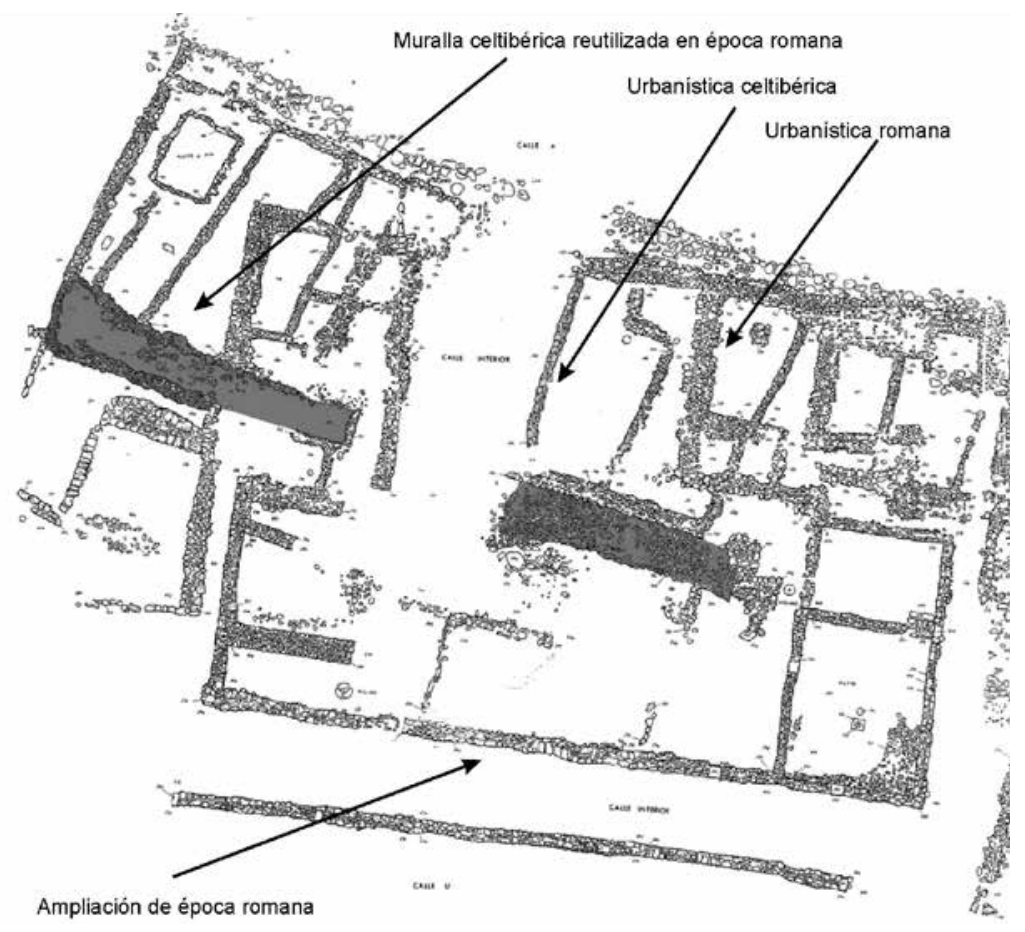

Fig. 4. Superposición de ciudades, según A. Schulten.

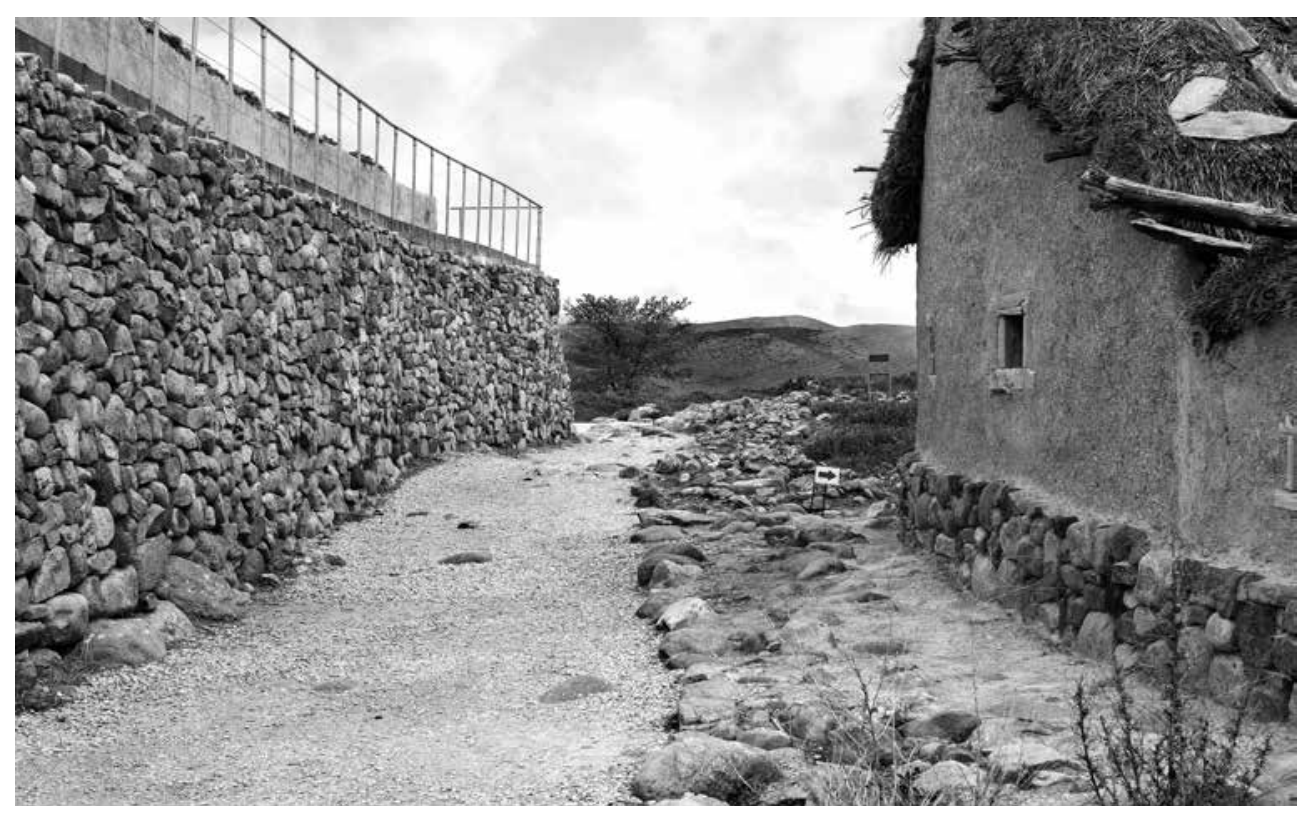

Fig. 5. Las casas de la ciudad destruidas por Escipión dejaban entre su parte posterior y la muralla una calle de ronda. 
La Comisión no tomó en consideración los trabajos estratigráficos realizados por Schulten ${ }^{2}$ y Köenen en la Manzana IV, donde documentaron por debajo de la ciudad romana, junto a la muralla, dos niveles superpuestos, atribuyendo el más antiguo a la ciudad destruida por Escipión en el 133 a. C. y la ciudad superpuesta a la anterior, que tendría su final con las Guerras Sertorianas (75-72 a. C.). Las casas del nivel inferior, que miden $12 \mathrm{~m}$ de longitud y unos $3 \mathrm{~m}$ de anchura, estaban divididas en tres estancias (Fig. 4). Desde la primera se accedía a otra estancia subterránea o «bodega», de $2 \mathrm{~m}$ de profundidad que servía como almacén para conservar los alimentos. Lo que no observó Schulten es que estas casas dejaban entre su lado estrecho posterior y la muralla una calle de ronda ${ }^{3}$ (Fig. 4).

En los últimos años, los trabajos de excavación, realizados por debajo de la Manzana XXIII de época romana, han permitido documentar que la construcción de la ciudad de época imperial conllevó el arrasamiento de las ciudades inferiores, a excepción de los espacios adosados a la muralla, donde se ha conservado la estratigrafía más completa, ya que al construir la ciudad de época romana, se utilizaron los restos de la muralla celtibérica como bancal ${ }^{4}$.

Estos trabajos, previos a la edificación de la nueva ciudad, afectaron sobre todo al asentamiento de época sertoriana (75-72 a. C.) y también, en alguna medida, a la ciudad celtibérica destruida por Escipión Emiliano (133 a. C.). Pero ésta ha podido ser mejor documentada al mantener la base de los muros de las casas embutidos en el manto natural. Se puede observar como algunas de estas estancias prolongan sus muros por debajo de los que delimitan la manzana romana, insinuando un esquema urbanístico muy diferente ${ }^{5}$ (Fig. 5).

Sería conveniente en los próximos años ampliar el espacio de excavación, para poder conocer no sólo las casas, sino también las características de la urbanística de la ciudad, ya que las fuentes nos hablan de barrios diferenciados, como era en el que vivía el jefe numantino Retogenes, ya que según Valerio Máximo (3,2, ext.7) «hizo un montón de materias inflamables en su barrio, el más hermoso de la ciudad, y le prendió fuego» ${ }^{6}$.

\section{EL PESO DE LAS CERÁMICAS}

La ordenación estratigráfica del yacimiento arqueológico de Numancia ha estado fijada por sus cerámicas más características, situando las cerámicas monocromas a partir del 75 a. C. y las bicromas y policromas a finales del siglo I a. C., por influencia del mundo romano ${ }^{7}$. Los trabajos actuales han proporcionado nuevas bases arqueológicas, que

\footnotetext{
2 SCHULTEN, 1945: 170.

${ }^{3}$ JIMENO et al., 2016.

${ }^{4}$ JIMENO et al., 2017.

${ }^{5}$ JIMENO et al., 2012: 209.

${ }^{6}$ JIMENO et al., 2016.

${ }^{7}$ WATTENBERG, 1963; ROMERO CARNICERO, 1976.
} 


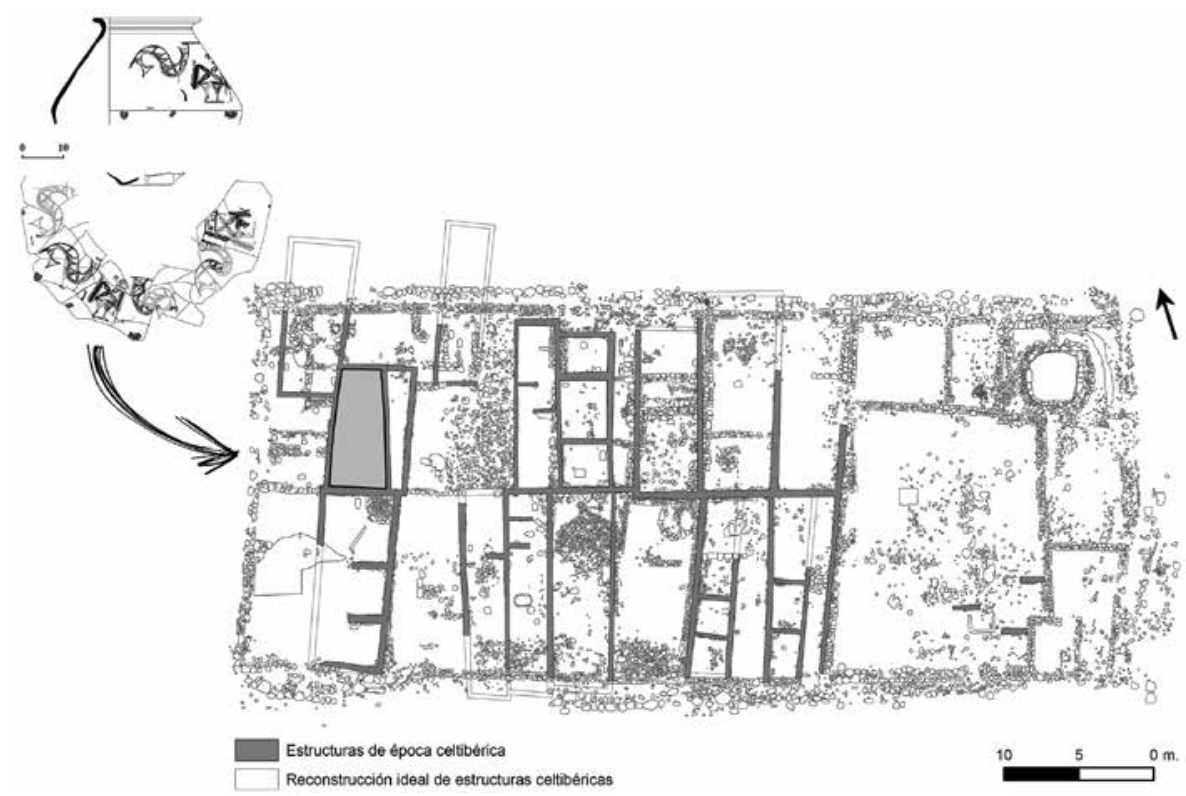

Fig. 6. Manzana con casas celtibéricas destruidas por Escipión (133 a. C.), diferenciando la casa del almacén y una de sus cerámicas.

indican una mayor antigüedad de estas producciones, relacionándolas con la Numancia histórica, destruida por Escipión en el 133 a. C., lo que ha conllevado revisar los aspectos iconográficos y ajustar el discurso interpretativo a la nueva realidad temporal e histórica.

Por debajo de la urbanística romana de la Manzana XXIII, se ha descubierto un conjunto de casas del nivel celtibérico, destruido por Escipión (133 a. C.). Una de estas casas había conservado solo parte de la cocina (con su hogar), al estar en un nivel más elevado. No obstante, el almacén dependiente de esta casa se había conservado por completo al estar rehundido en el manto natural, por lo que se ha podido estudiar su contenido (114 objetos) y restos del maderamen quemados, que han proporcionado una fecha de C-14:340 $\pm 50^{8}$.

Una de estas vasijas hallada en el almacén mostraba una decoración, que como es usual en este tipo de grandes vasos, se desarrolla en la zona superior, entre el borde y la carena central. Sobre una capa de engobe blanco se representaron cuatro «caballos serpentiformes» ${ }^{9}$ contrapuestos dos a dos, separados por estructuras trapezoidales verticales. Presentan el típico hocico aflautado, finas orejas puntiagudas y pequeña cabeza, que acogen grandes ojos, que miran fijos y frontalmente, muy característicos de los artistas numantinos ${ }^{10}$ (Fig. 6).

\footnotetext{
${ }^{8}$ JIMENO et al., 2012.

${ }^{9}$ LICERAS GARRIDO, 2014: 331, 338.

${ }^{10}$ WATTENBERG, 1963: lams. II-VII.
} 


\section{LA APORTACIÓN DE LA NECRÓPOLIS}

La excavación de la necrópolis de Numancia aporta una cronología desde el s. IV hasta la destrucción de la ciudad en el 133 a. C. La nueva interpretación estratigráfica de Numancia nos lleva a considerar la relación que debe de existir entre los restos arqueológicos hallados en la ciudad, teniendo en cuenta el papel destacado que aportan las decoraciones figuradas en las cerámicas ${ }^{11}$, con los objetos que han proporcionado la necrópolis celtibérica ${ }^{12}$.

Se observa en la necrópolis, a lo largo de los siglos III y II a. C., como la iconografía se hace más rica y figurativa, que en la etapa precedente, pudiendo establecer relaciones entre la ciudad y la necrópolis. Están bien documentados los remates decorativos de bronce, con gran contenido simbólico, de dos báculos decorados con protomos de caballos, montados por un jinete, sustituidas sus patas por cabezas humanas ${ }^{13}$. La iconografía de las cabezas guarda relación con una serie de cerámicas de la ciudad que incorporan en su decoración representaciones de cabezas en relieve ${ }^{14}$ (Fig. 7).

Los broches de cinturón hallados en la necrópolis son similares a los representados en las cerámicas, diferenciándose entre los usados por los hombres y las mujeres. La escena en la que se representa en un fragmento de cerámica

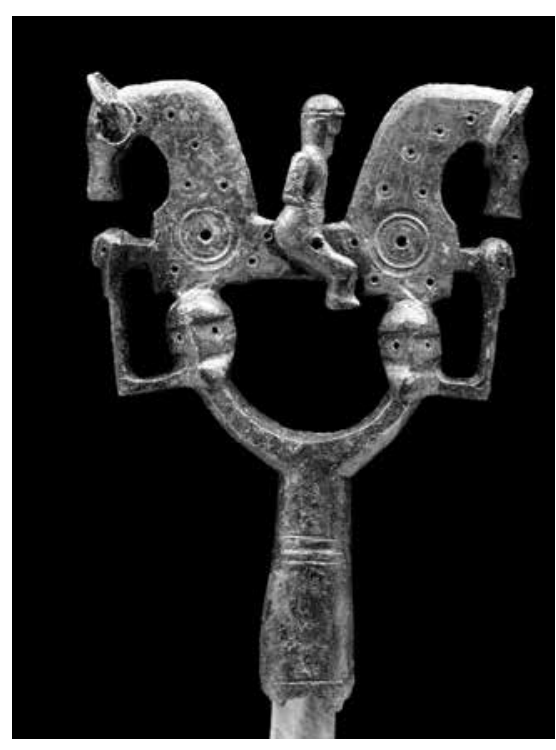

Fig. 7. Báculo de distinción, realizado en bronce, procedente de la necrópolis.

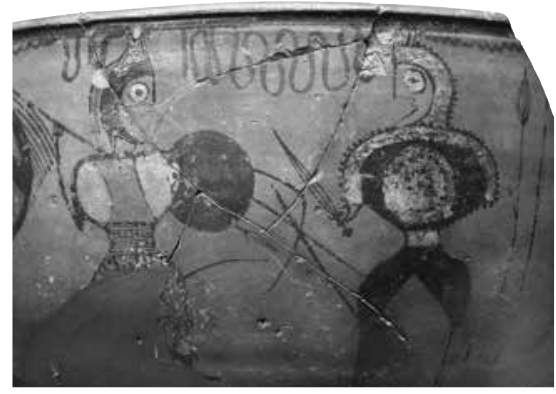

Fig. 8. Vaso de «Los Guerreros», procedente de la ciudad. a un oficiante o «sacerdote», con ampulosa túnica y tocado cónico, realizando el ritual sacrificial de un ave sobre un ara, muestra claramente elementos de indumentaria bien constatados en la tumbas de la necrópolis, como son los anchos cinturones con sus broches. También se relacionan las armas representadas en el vaso de Los Guerreros, con las halladas en la necrópolis ${ }^{15}$ (Fig. 8).

\footnotetext{
11 TARACENA, 1924; WATTENBERG, 1963; ROMERO, 1976.

12 JIMENO, 1996; JIMENO et al., 2004.

${ }^{13}$ JIMENO et al., 2004: fig. 50, 5 y 6.

${ }^{14}$ WATTENBERG, 1963: tab. XXXVI, 1021; lám. VI: 1203; XXXVII: 1038.

${ }^{15}$ WATTENBERG, 1963: lám. XVI: 1295; ROMERO CARNICERO, 1976: 53; JIMENO et al., 2004: 191-199.
} 


\section{¿QUIENES REOCUPARON EL CERRO DE LA MUELA DESPUÉS DE LA DESTRUCCIÓN DE NUMANCIA POR ESCIPIÓN?}

Tras la caída y destrucción de Numancia, en el 133 a. C., según Apiano ${ }^{16}$, Escipión «Reservándose cincuenta (de los vencidos) para el triunfo, vendió todos los restantes y arrasó la ciudad»...«distribuyó el territorio de Numancia entre los vecinos, decidió las cuestiones pendientes en las demás ciudades, amonestó y multó a las sospechosas, y se hizo a la mar en dirección a Roma». Es muy probable, que los denominados vecinos haya que relacionarlos con la tribu de los Pelendones, que no aparecen citados en los textos clásicos en las guerras de Roma con Numancia, por lo que no debieron tener ningún conflicto con los romanos.

Roma envió, según indica Apiano ${ }^{17}$ : «a las zonas de Iberia recién adquiridas» una comisión senatorial "como era costumbre», formada por diez senadores que tenía como misión la recogida de información, para la elaboración de un plan de actuación sobre las zonas conquistadas, para «organizarlas sobre una base de paz» ${ }^{18}$.

La Comisión de Excavaciones (1906-1923) mantuvo que se produjo una despoblación del cerro de La Muela, entre la ciudad tomada por Escipión, en el 133 a. C, y la nueva ciudad que se levantaría en época de Augusto, a partir del 29 a. C. ${ }^{19}$. Este planteamiento, no se ve avalado por la documentación arqueológica, ahora conocida, ya que la existencia de un significativo número de monedas autónomas y romanas, fechadas entre el 133 y el 75 a. C., indican relaciones comerciales de Numancia con ciudades del valle del Ebro y del noreste peninsular (Fig. 9). A esta documentación monetal hay que añadir también la información, que alude a la participación de Numancia en las Guerras Sertorianas del hallazgo de un glande de plomo con la estampilla de Sertorio, en uno de los campamentos de La Atalaya de Renieblas ${ }^{20}$.

Además de la información monetal, tenemos la documentación de los trabajos de excavación realizados por Schulten ${ }^{21}$ y Köenen en la Manzana IV, en la que pudieron documentar, por encima de la ciudad destruida por Escipión, en el 133 a. C., y debajo de la romana imperial, otra de estructura celtibérica. Las casas de esta ciudad son también rectangulares pero más anchas y largas $(16 \mathrm{~m}$ por $6 \mathrm{~m})$, apoyándose en la muralla celtibérica por su parte estrecha posterior, que fue destruida en las Guerras Sertorianas (75-72 a. C.). No obstante, esta ciudad es la que ha sufrido más los trabajos de la construcción de la ciudad romana, situada encima. No obstante, la

\footnotetext{
${ }^{16}$ Iber., 98.

${ }^{17}$ Iber., 99.

${ }^{18}$ PINA, 1997: 83.

${ }^{19}$ MÉLIDA, 1922: 180-182.

${ }^{20}$ GÓMEZ-PANTOJA \& MORALES, 2002: 303.

${ }^{21}$ SCHULTEN, 1954: 157 y 170.
} 


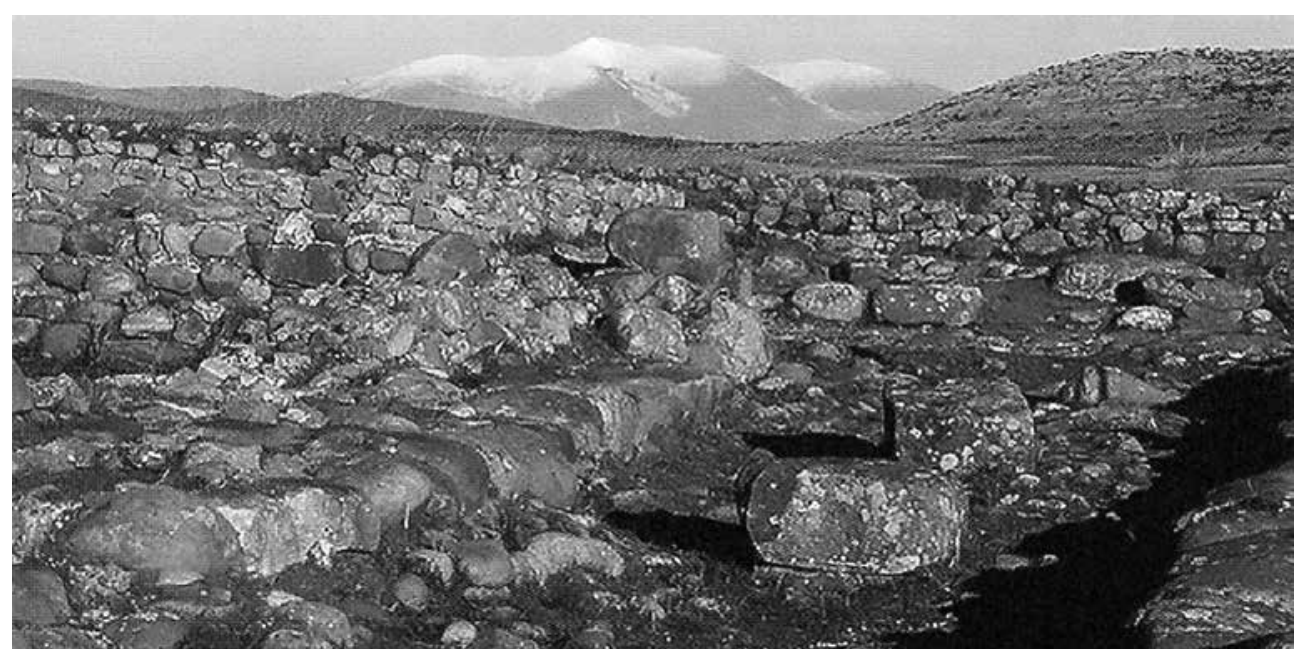

Fig. 9. Urbanística de casas de la ciudad destruida en las Guerras Sertorianas (75-72 a. C.).

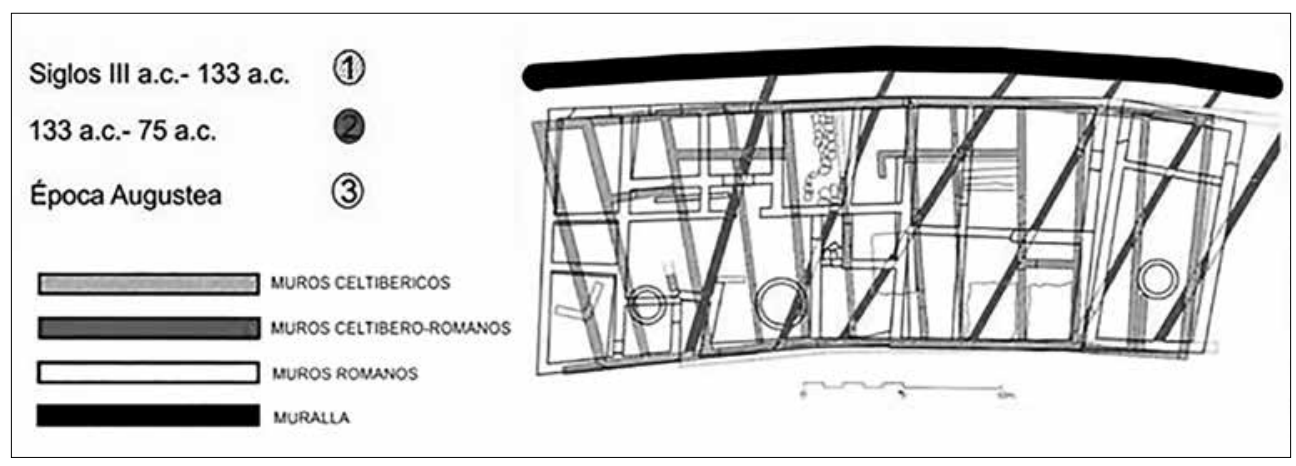

Fig. 10. Monedas de las ciudades celtibéricas de Arsaos y Arekorata.

Fig. 11. Superposición de las dos fases de la ciudad romana.

hemos podido documentar en la limpieza y reexcavación realizada en la Manzana I, situada en el Barrio Sur ${ }^{22}$ (Fig. 10).

\section{NUMANCIA: CIUDAD PEREGRINA EN ÉPOCA DE AUGUSTO}

Desde la ciudad destruida en las Guerras Sertorianas (75-72 a. C.), Numancia no se volvió a ocupar hasta época imperial, con Augusto. Las Guerras Cántabras, que se desarrollaron a partir del 29 a. C., obligaron a desplazarse a la Península al propio Octavio, para someter a cántabros y astures y controlar definitivamente la Meseta. Parece probable que fuera entonces cuando se fundaron algunas ciudades (mansiones) en esta zona, como Augustobriga, Numancia y Uxama, situadas en

22 JIMENO \& CHAÍN, 2005-2006. 
función de la vía XXVII del Itinerario de Antonino, que pasaba al pie de Numancia. Esta vía que se dirigía desde Caesaraugusta a Asturica era de gran importancia para trasladar las legiones con rapidez y sofocar el levantamiento de cántabros y astures. Esto es lo que explica la necesidad de la repoblación de Numancia, siendo de nuevo citada por Plinio ${ }^{23}$ en un momento ya tardío, s. I d. C., relacionándola con la tribu de los pelendones ${ }^{24}$.

Si analizamos detenidamente la urbanística de la ciudad romana, que es la que han dejado visibles los trabajos de La Comisión y que oculta el trazado general de las ciudades anteriores, podemos observar como hay una primera planificación muy simétrica y una ruptura de esa planificación en un momento posterior. La ciudad fue trazada inicialmente en forma de "almendra», adaptando o condicionando su límite por la zona sur, norte y oeste a la línea de muralla celtibérica, que sería todavía visible, sirviendo de bancal de aterrazamiento, para adaptar las nuevas construcciones, tanto por el interior como por el exterior. No ocurrió lo mismo en el lado oeste, donde inicialmente la urbanística de la ciudad romana no alcanzó la línea de la muralla antigua hasta una ampliación posterior (Fig. 11).

Para la construcción de la ciudad augustea se llevó a cabo inicialmente un arrasamiento de los restos constructivos de las dos ciudades celtibéricas más antiguas, la inicial destruida por Escipión y la posterior en las Guerras Sertorianas, enrasando todo el cerro hasta llegar al manto natural. Este barrido ha condicionado la conservación de las ciudades anteriores. De la ciudad destruida por Escipión se han mantenido aquellas casas que tenían la base de sus muros embutidos en el manto natural, así como las estancias subterráneas o bodegas y las casas próximas a la muralla. Esta defensa también ha protegido algunas de las casas destruidas en época sertoriana, que se dispusieron sobre la celtibérica anterior, pegadas a la muralla.

La razón de que hayan quedado muestras de viviendas de las antiguas ciudades en las zonas pegadas a la muralla, se explica porque al construir la ciudad romana quisieron mantener los restos de la muralla celtibérica, para utilizarla como bancal de aterrazamiento, por lo que en estas zonas no rebajaron sino que incluso rellenaron, lo que permitió que fueran documentadas por Schulten ${ }^{25}$ en su excavación de la manzana-IV y en la limpieza que realizamos en el Barrio Sur ${ }^{26}$.

La ciudad se ordenó con un esquema indígena, en torno a dos largas calles (C-B y C-D) que presentan cierta sinuosidad, trazadas en dirección norte-sur y un número mayor de calles, unas 19, en dirección Este-Oeste, para protegerse mejor del viento dominante. A su vez la ciudad quedaba circunvalada por una calle de

\footnotetext{
${ }^{23}$ III, 26 y IV, 112.

${ }^{24}$ CAPALVO, 1996: 67.

${ }^{25}$ SCHULTEN, 1945: 170.

${ }^{26}$ JIMENO \& CHAÍN, 2005-2006: 251-254.
} 


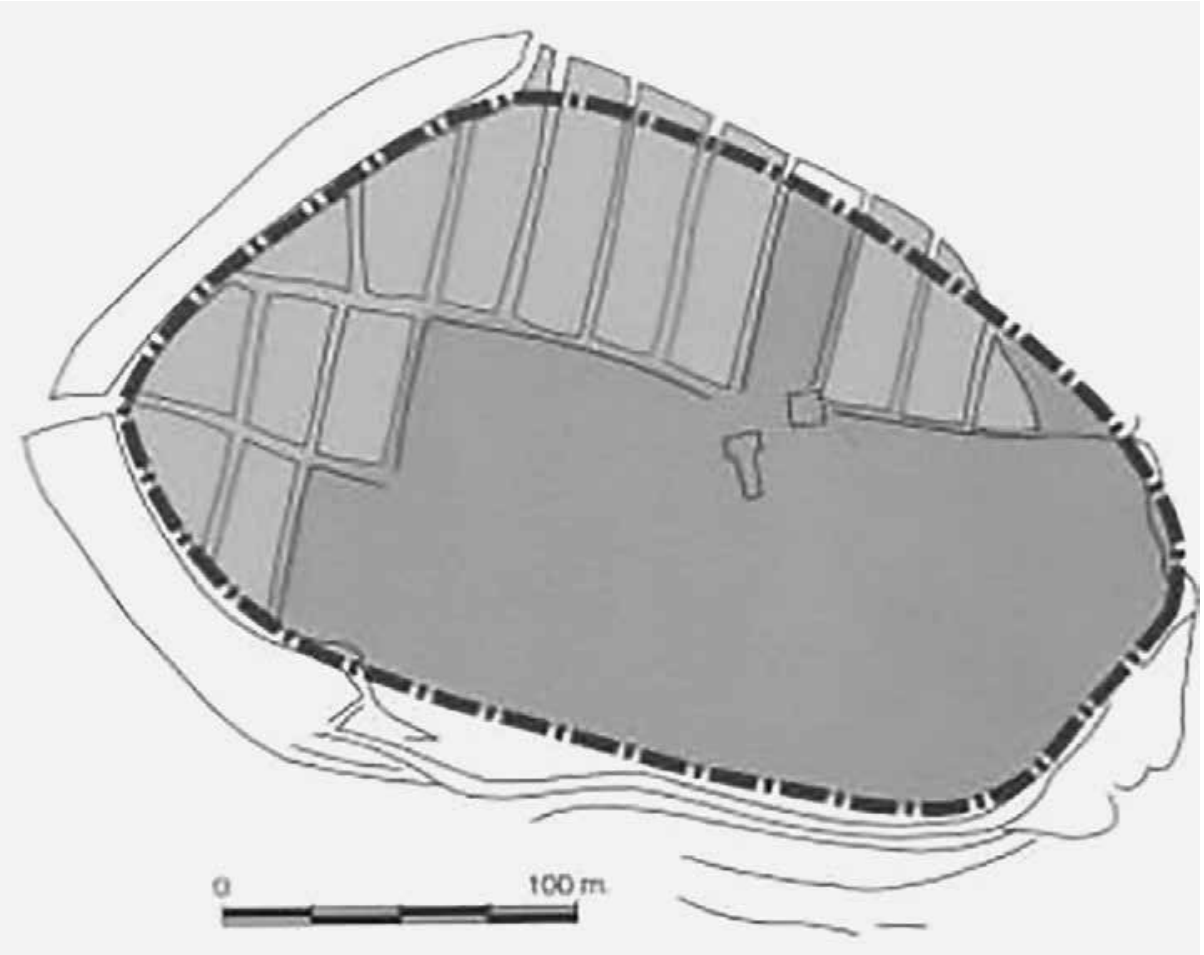

Fig. 12. Urbanística y extensión de la primera fase de la ciudad romana.

ronda, limitada por el trazado de las manzanas interiores y por la muralla con casas adosadas superpuestas sobre los restos de las anteriores celtibéricas, amortizando de esta manera la línea defensiva de la ciudad antigua.

Dejando a parte la adaptación urbanística de la muralla, el interior de la almendra quedaba perfectamente dividida en dos franjas externas, de forma elíptica, totalmente simétricas y manteniendo proporciones y espacios geométricos muy similares: triangulares para adaptase a los extremos de la elipse y manzanas rectangulares más grandes según se elevaba el arco semicircular con sus lados más o menos curvados, según se iba ampliando la anchura de la elipse; a su vez el lado opuesto de éstas se adaptaban a la linealidad mayor o menor de una y otra calle. Las manzanas de la ciudad (unas 20), delimitadas por las dos calles principales (B y D), son de forma rectangular y algo más grandes que las laterales; sólo las situadas en los extremos curvan uno de sus lados para amoldarse a la delineación de la forma almendrada (Fig. 12). 


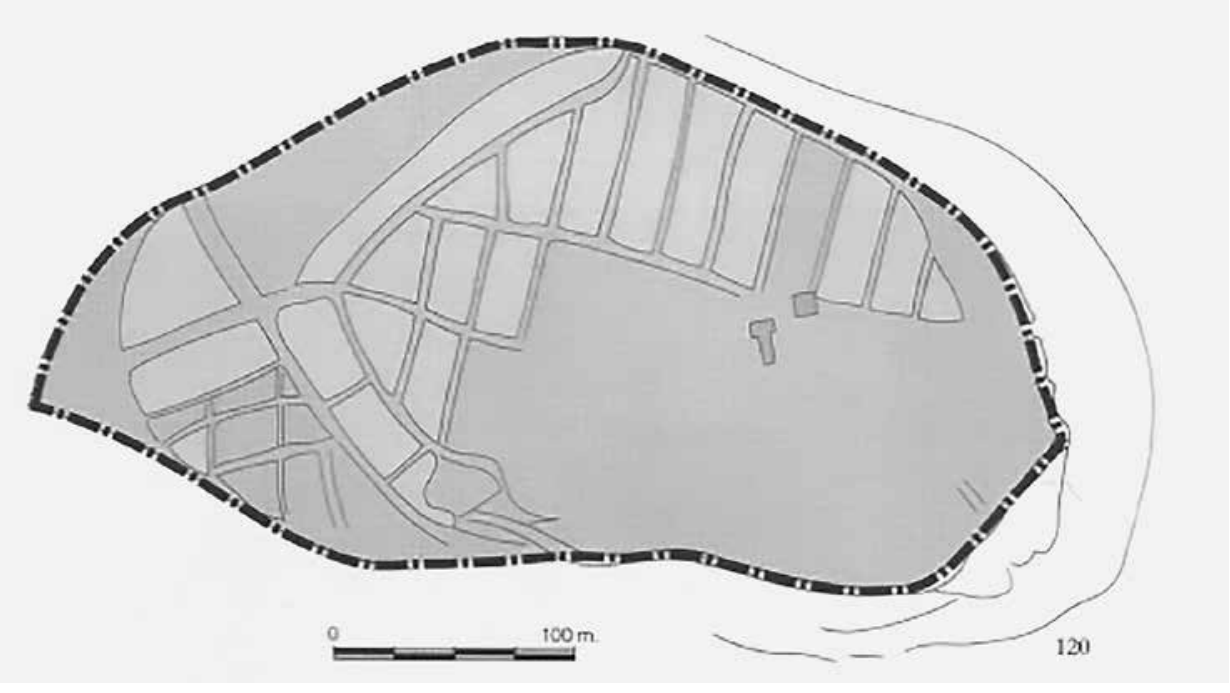

Fig. 13. Urbanismo y extensión de la segunda fase de la ciudad romana.

\section{NUMANCIA: MUNICIPIUM EN ÉPOCA FLAVIA}

En un momento posterior, en época Flavia, cuando la ciudad recibe la concesión del Ius Latii y el grado de municipium ${ }^{27}$ conllevó un aumentó de población. La ciudad va a engrandecerse, ocupando la zona occidental de la meseta, que había quedado libre. Esta actuación consistió en alterar el trazado original de las manzanas y calles de la zona oeste, para prolongarlas hasta el límite que imponía la línea de la muralla celtibérica, sobre la pendiente natural del cerro, dejando una estrecha calle de ronda entre las manzanas y la muralla. Sólo en el lado norte se puede observar la línea de la muralla celtibérica sin adosamientos de casas. Esta expansión se trasladó también a la ladera sur, donde la ciudad fue ampliada unas tres hectáreas (Fig. 13).

Será ahora cuando la ciudad se va a dotar de cierta monumentalidad, construyendo aquellos edificios públicos característicos de toda ciudad romana: un arco honorífico delante de la entrada a la ciudad; un edificio público con patio columnado, probablemente la Curia; dos termas, unas para hombres y otras para mujeres; así como un templo in antis, en una de las dos calles principales. No obstante, la ciudad no perdió sus características indígenas, ya que el mayor número de casas siguieron manteniendo su techado con cubierta vegetal, desechando la tegula y la imbrex romana, pero transformaron las características del espacio doméstico, en relación con la ciudad celtibérica, incorporando módulos cuadrangulares de mayores dimensiones y compartimentados funcionalmente (Fig. 14). 


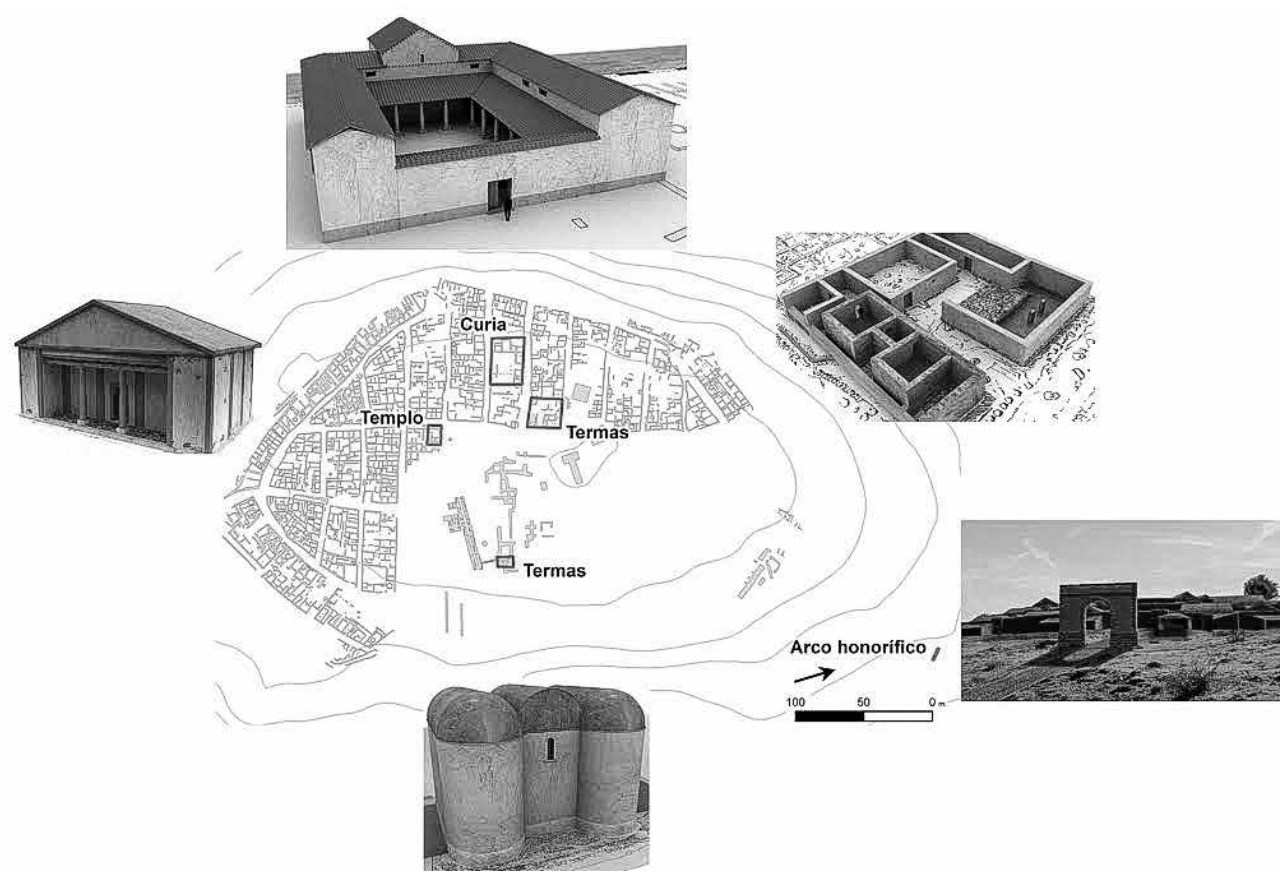

Fig. 14. Instalaciones y monumentos característicos de una ciudad romana.

Este proceso de cambio necesitaría de un tiempo para acomodar las estructuras indígenas y los modos de vida, con ellas relacionadas, a las exigencias de la nueva realidad socioeconómica. Sería la riqueza ganadera, bien atestiguada en la etapa celtibérica, la que recibiría un gran impulso, vinculada al desarrollo de una industria textil, aprovechando los cauces de comercialización propiciados por el Imperio ${ }^{28}$.

En Numancia, a partir de época flavia, se acusará progresiva, pero lentamente el peso del aparato ideológico y socioeconómico del Imperio, a través de las instituciones municipales. Este despegue de Numancia comportó un mayor aprovechamiento agrícola del entorno, posiblemente basado en el cereal de trigo y cebada. Así lo muestra la existencia de pequeños asentamientos rústicos o villae en las proximidades de la ciudad, como los de Castillejo, Peñas Altas, Peña Redonda, Merdancho, Valdelilo, Las Revillas y La Vega ${ }^{29}$. Los análisis polínicos indican también la existencia de drenajes en las orillas de los ríos, destinados al acondicionamiento de tierras para huertos. En este sentido hay que comentar la noticia de Plinio ${ }^{30}$, correspondiente al s. I, que nos habla de la fama que tenían en Roma las peras numantinas (pira numantina), una variedad de pera tardía, que incluso llegó a ser artículo de lujo.

\footnotetext{
${ }^{28}$ BERMEJO, 2014: 328-329.

${ }^{29}$ SCHULTEN, 1914; MORALES, 1995.

${ }^{30} \mathrm{XV}, 55$.
} 


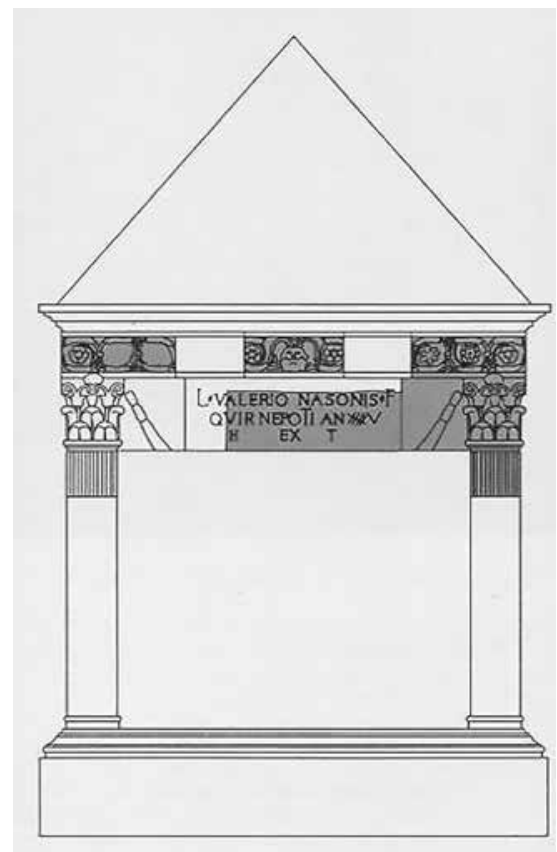

Fig. 15. Monumento funerario dedicado a $\mathrm{L}$. Valerio Nepote.

También se acusa un aumento del número de personas que constituyen las unidades domésticas, reflejadas en la presencia de esclavos, que formaban parte de la domus, lo que queda atestiguado en dos lápidas funerarias, ahora embutidas en las paredes de la ermita románica del pueblo de Garray, fechadas en el siglo II y dedicadas por dos esclavos libertos en agradecimiento a sus patronos. Una de las inscripciones la dedica Herennivs Modestvs a Lucivs Herennivs Eudemvs y otra Luporvs a Lucivs Gallvs Avitvs. En la primera de las inscripciones se puede observar como ha funcionado la transmisión de nombres, ya que el del liberto está formado por el nomen de su patrono, Herennius, y por el que tenía antes de ser liberto Modestus ${ }^{31}$.

Los rasgos de monumentalidad que se acusan en Numancia, a partir de época Flavia, se ven refrendados por la construcción de un magnífico monumento funerario que fue desmantelado. Sus sillares, con sus correspondientes adornos, fueron trasladados y embutidos en diferentes construcciones de los pueblos de su entorno, a partir de estos pudo realizar gráficamente una restitución parcial del mismo. El monumento estaba dedicado a L(ucio) VaALERIO NASONIS F(ilio) / QVIR(ina tribu) NEPOTI AN (orum) / H(eres) EX T(estamento). A Lucio Valerio Nepote, hijo de Nason, de la tribu Quirina, de 45 años, el heredero del testamento. Este monumento estaría situado próximo a la vía romana, número XXVII del Itinerario de Antonino, situada al pie mismo de Numancia. Se trataría de un personaje vinculado a la élite local ${ }^{32}$. (Fig. 15)

El proceso de monumentalidad en Numancia se centra fundamentalmente en los edificios públicos, pero las estructuras domésticas siguen manteniendo, en gran medida, las mismas características que en la fase anterior, con sus cubiertas de paja. Sólo destacan las casas del barrio sur, el más agradable de habitar, que en un intento de remedar la domus romana se dotan de un patio porticado con columnas toscanas (Fig. 16). Este barrio estaría ocupado por el grupo acomodado de la ciudad, ya que se halló en una de estas casas el equipo quirúrgico de un medicus y en otra una colección

\footnotetext{
${ }^{31}$ JIMENO, 1980: 82-85.

${ }^{32}$ GUTIÉRREZ BEHEMERID, 1993.
} 

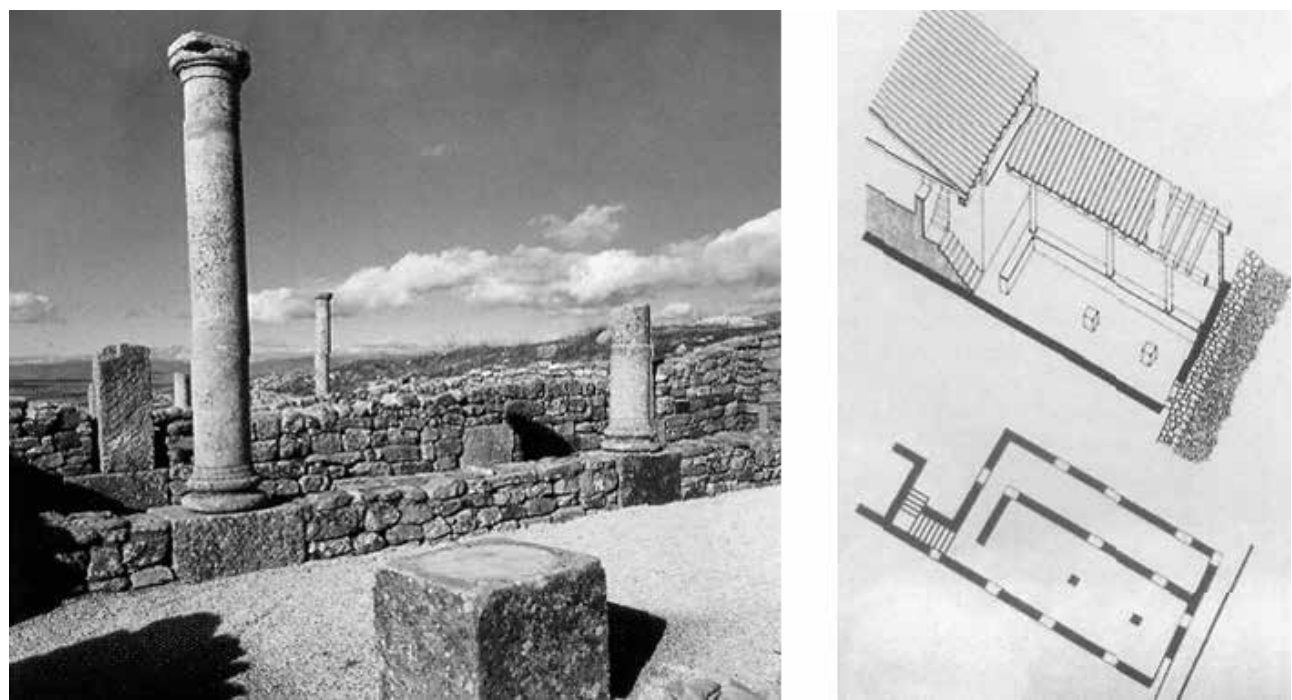

Fig. 16. Casas con patios porticados en el barrio sur, de época Flavia (68-65 d.C.).

de stila para escribir sobre tablilla de cera, que estaría relacionada con un notarius. Se acusa también una mejora de los servicios sanitarios, ya que el agua de lluvia se recogía en aljibes y el sobrante se conducía a las vertientes por pequeñas atarjeas. No obstante, es probable que la continuidad, en gran medida, del modelo tradicional indígena por un sector de la comunidad, aquella que quedaba al margen de las élites, como plantea ${ }^{33}$, se pudo haber mantenido hasta el inicio de época tardoantigua.

\section{BIBLIOGRAFÍA}

AA.VV. (1912) - Excavaciones de Numancia. Memoria presentada al Ministerio de Instrucción Pública $y$ Bellas Artes por la Comisión Ejecutiva, Madrid.

BERMEJO, J. (2014) - Arqueología biopolítica. La sintaxis espacial de la arquitectura doméstica romana en la Meseta Oriental. Madrid: La Ergastula Ediciones.

CAPALVO, A. (1996) - Celtiberia. Zaragoza: Institución «Fernando El Católico».

ESPINOSA, U. (1984) - Las ciudades arévacas y pelendonas en el Alto Imperio. Su integración Jurídica, Actas del Symposium de Arqueología Soriana. Soria: Diputación Provincial de Soria.

GÓMEZ-PANTOJA, J.; MORALES, F. (2002) - Sertorio en Numancia: una nota sobre los campamentos de la Gran Atalaya. In MORILLO, A., ed. - Arqueología Militar Romana en Hispania, 303-310, Madrid: CSIC.

GUTIERREZ BEHEMERID, Ma A. (1993) - El monumento funerario de Lucio Valerio Nepote de Numancia. «Boletín del Seminario de Arte y Arqueología», LIX, 155-167.

\footnotetext{
${ }^{33}$ BERMEJO, 2014: 31.
} 
JIMENO, A. (1980) - Epigrafía romana de la provincia de Soria. «Temas sorianos», núm. 2. Soria: Diputación Provincial de Soria. (1996) - Numancia: relación necrópolis-poblado. «AEsp.Arq.», 69.

JIMENO, A.; DE LA TORRE, J. I.; BERZOSA, R.; MARTÍNEZ, J.P. (2004) - La necrópolis celtibérica de Numancia, Arqueología en Castilla y León. «Memoria», 12. Salamanca: Junta de Castilla y León.

JIMENO, A.; CHAÍN, A. (2005-2006) - El plan de trabajo en Numancia, de 1962, y los problemas estratigráficos. «Kalathos», 24-25.

JIMENO, A.; CHAIN, A.; LICERAS, R.; QUINTERO, S. (2016) - La Numancia que resistió a Escipión Emiliano: Los Escipiones. Roma Conquista Hispania (Catálogo de la Exposición, Ed. Manuel Bendala). Madrid: Museo Arqueológico Regional; Comunidad de Madrid.

JIMENO, A; LICERAS, R; QUINTERO, S.; SANTOS, A. (2012) - Interpretación estratigráfica de Numancia y ordenación cronológica de sus cerámicas. «Complutum», vol. 23, núm. 1. Madrid: Universidad Complutense.

JIMENO, A.; REVILLA, M. L.; de la TORRE, J.I.; CHAÍN, A.; LICERAS, R. (2017) - Numancia. Guía Arqueológica. Soria: Asociación de Amigos del Museo Numantino y Junta de Castilla y León.

LICERAS GARRIDO, R. (2014) - Sobre el territorio de los Numantinos. II Jornadas de Jóvenes Investigadores del Valle del Dueró: Del Neolitico a la Antiguedad Tardía. Valladolid: Glyphos Publicaciones.

MÉLIDA, J. R. (1922) - Excursión a Numancia pasando por Soria. Madrid: Ed. Ruiz Hermanos.

MORALES, F. (1995) - Carta Arqueológica. Soria. La Altiplanicie Soriana, Dirigida por A. Jimeno, Excma. Diputación Provincial de Soria, Soria.

PINA, F. (1997) - Las comisiones senatoriales para la reorganización de Hispania (App.Iber.99-100), DHA, 23.2:83-104.

ROMERO CARNICERO, F. (1976) - Las cerámicas polícromas de Numancia. Valladolid: C.E. Sorianos, Valladolid.

SAAVEDRA, E. (1861) - Descripción De la Vía Romana entre Uxama y Augustobriga. Madrid.

SCHULTEN, ADOLFO (1914-1931) - Numantia. Die Ergebnisse der Ausgra bungen, 1905-1912, München, vol. II. (1945) - Historia de Numancia. Barcelona: Ed. Barna. (1954) - Fontes Hispaniae Antiquae. Barcelona: [s.n.].

TARACENA, B. (1924) - La cerámica ibérica de Numancia. Madrid.

WATTENBERG, F. (1963) - Las cerámicas indígenas de Numancia. Bibliotheca Praehistorica Hispana, IV. Madrid: Instituto Español de Prehistoria del C.S.I.C., y Diputación de Valladolid. 


\title{
O URBANISMO DE BRACARA AUGUSTA: MODELO E ESPECIFICIDADES NO CONTEXTO DO NOROESTE PENINSULAR*
}

\author{
MANUELA MARTINS** \\ JORGE RIBEIRO***
}

\section{INTRODUÇÃO}

O programa de urbanização empreendido por Augusto no NO da Hispânia que contemplou a fundação de três cidades destinadas a funcionar como capitais de conventos jurídicos, representou um poderoso mecanismo de transformação do território e dos seus modelos de ocupação e um importante contexto de aculturação das populações indígenas. De facto, considerando que a região do NO peninsular representava uma zona com reduzida influência romana, anteriormente às guerras cantábricas, é forçoso reconhecer o alcance da fundação das três capitais conventuais (Bracara Augusta, Lucus Augusti e Asturica Augusta), que se inseriu numa estratégia de controlo administrativo do território, mas também de criação de mecanismos de integração que garantissem uma necessária estabilidade da região e a difusão dos modelos de organização romanos. Assim, a política urbana de Augusto para o NO, inserida num mais vasto contexto urbanizador da Hispânia, para além dos efeitos práticos de dotar a região de centros administrativos capazes de assegurar uma relação eficaz com a administração provincial e imperial, constituiu uma estratégia

\footnotetext{
* Este trabalho teve o apoio financeiro do Projeto UID/AUR/04509 e da FCTMEC através de fundos nacionais e quando aplicável do cofinanciamento do FEDER, no âmbito do novo acordo de parceria PT2020.

** UAUM, Lab2PT, UMinho. mmmartins@uaum.uminho.pt.

*** Bolseiro de pós-doutoramento da FCT (SFRH/BPD/79511/2011); UAUM, LAB2PT, UMinho. joribeiro@ portugalmail.pt.
} 
que potenciou o desenvolvimento e a transformação do território através de novas formas de exploração dos recursos e de novas expressões de povoamento, algumas da quais de carácter urbano.

Sendo certo que o quadro da urbanização do NO peninsular carece hoje, no quadro dos conhecimentos disponíveis, de uma necessária visão de síntese, pois a sua análise está ainda muito regionalizada, é forçoso reconhecer, também, que a profundidade do que se sabe relativamente às três capitais conventuais é muito desigual, sendo difícil esboçar um quadro comparativo dos modelos de organização das três cidades, quer no que respeita ao urbanismo e arquitetura, quer no que se refere à sua relação com o território, ou à sua diferenciada composição social. Nesse sentido, e considerando os conhecimentos disponíveis, procuraremos discutir nesta comunicação o modelo urbano de Bracara Augusta, no contexto do quadro sociocultural pré-romano da região galaico bracarense, o qual poderá justificar boa parte da sua especificidade relativamente ao que se conhece das outras cidades augustas do NO da Hispânia.

\section{BRACARA AUGUSTA NO CONTEXTO DA URBANIZAÇÃO DO NO PENINSULAR}

\subsection{O processo de integração e a criação das capitais conventuais}

Entre as questões historiográficas que tradicionalmente se colocaram relativamente à integração e urbanização do NO destacamos três, cuja avaliação depende de dados de natureza textual e que se articulam diretamente com a reforma administrativa de Augusto, como seja a integração provincial, a organização conventual e o estatuto jurídico das respetivas capitais. Mais dependentes dos resultados da arqueologia estão outras questões relacionadas a cronologia da fundação dessas cidades e com a sua origem civil, ou militar.

Relativamente à integração provincial do NO sabe-se hoje, graças ao conteúdo da tabula de bronze de Bembibre, datada do ano 15 a. C., que as regiões de Asturia e Callaecia se encontravam nessa data integradas na província Transduriana, hipoteticamente criada em 25 a. C., para fazer face às necessidades militares e organizacionais associadas às guerras cantábricas e ao controle do território, ainda que o seu efetivo funcionamento possa ser mais tardio, em torno do ano 22 a. C., por ação de L. Sestio Quirinal ${ }^{1}$. Sabemos que a vida dessa província foi curta, tendo os territórios do NO ibérico acabado por ser integrados na Citerior ${ }^{2}$, ainda durante a última estadia ocidental de Augusto, que terá tido por objetivo o ultimar da divisio provincial

\footnotetext{
${ }^{1}$ VILLANUEVA ACUNA, 2011.

${ }^{2}$ VILLANUEVA ACUÑA, 2016.
} 
da Hispânia em três províncias e a organização da malha conventual ${ }^{3}$. Também a questão historiográfica relativa à criação dos conventos jurídicos parece estar hoje ultrapassada, tendo por base os dados propiciados pela tabula Lougeiorum, datada do ano 1, onde se encontra referido o conventus Ara Augustae, facto que não deixa dúvidas quanto à assinatura de Augusto na subdivisão das províncias em unidades administrativas de carácter judicial, presumivelmente ultimada entre 16 e 13 a. C. . Já a questão da natureza jurídica das três capitais provinciais permanece problemática, por ausência de evidências epigráficas sugestivas do seu estatuto, ou eventual promoção municipal em época flávia. No entanto, considerando a relevância política e administrativa das três cidades e sendo certo que possuíam instituições de governo semelhantes aos municípios, parece hoje bastante verosímil que possam ter gozado do direito latino desde a sua fundação ${ }^{5}$.

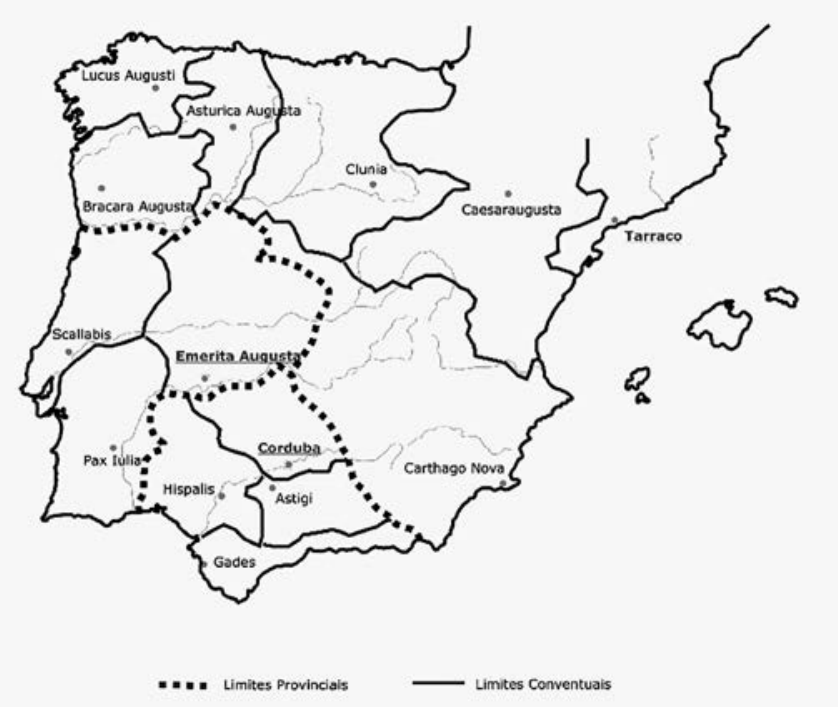

Fig. 1.

Bracara Augusta no contexto administrativo da Hispânia romana.

Problemática é também a cronologia da fundação das três capitais conventuais do NO, quando se contrapõem os dados textuais e arqueológicos disponíveis. Segundo Dio Cássio (54.23.7) deve-se a Augusto a fundação de várias cidades hispânicas, sendo sugestivo pensar que esse programa urbanístico tenha coincidido com a estadia do imperador no Ocidente, entre 16 e 13 a. C. No entanto, a articulação desta data com os dados arqueológicos resultantes das escavações urbanas realizadas em Braga, Lugo e Astorga não é fácil, assinalando consideráveis desfasamentos nas três cidades, que se articulam com a questão da sua origem civil ou militar. No caso de Asturica Augusta

\footnotetext{
${ }^{3}$ SALINAS DE FRIAS, 2001.

${ }^{4}$ DOPICO CAÍNZOS, 1986; DOPICO CAÍNZOS, 1988; DOPICO CAÍNZOS, 2009.

${ }^{5}$ LE ROUX, 1994; LE ROUX, 2004.
} 
sabemos que o núcleo urbano sucedeu a um prévio acampamento romano da Legio $X$ Gemina, datado entre 15-10 a. C., pelo que a origem da cidade poderá situar-se no início do reinado de Tibério, entre os anos 15-206. Já no caso de Lucus Augusti parece mais problemático acertar uma cronologia fundacional baseada nos dados arqueológicos disponíveis, pois a sua suposta origem militar, defendida por alguns autores ${ }^{7}$, com base num presumível acampamento, que dataria entre 25-15 a. C., não parece conhecer grande aceitação, uma vez que se suporta em evidências muito discutíveis. Discutível é também uma presumível presença de Paulus Fabius Maximus em Lugo, anteriormente aos anos 3/2 a. C., à luz dos dados disponíveis sobre a sua carreira ${ }^{8}$. De facto, as três inscrições de Lugo, que referem o legado, poderão ter a mesma cronologia da dedicatória de Braga, feita a Augusto, no dia do aniversário do legado, datada entre $3 / 2$ a. C. ${ }^{9}$. Importa, contudo, ter em conta as particularidades distintivas dos monumentos erguidos nas duas cidades, bem como as respetivas dedicatórias, pois, enquanto em Lugo estamos perante estelas, que foram dedicadas pelo próprio legado, em Braga a dedicatória foi feita a Augusto pelos bracaraugustani, sendo o suporte um pedestal de estátua, em forma de coluna. A natureza diferenciada dos monumentos e dedicantes subentende contextos narrativos diversos que remetem para momentos diferentes do próprio processo de fundação e ocupação das duas cidades ${ }^{10}$. Por outro lado, o monumento de Braga deve ser valorizado em conjunto com outros ${ }^{11}$, de cronologia muito próxima, que atestam a organização do corpo cívico da cidade, muito ligado à figura de Augusto e seus familiares diretos, apontando para a existência de espaços condignos para a colocação de estátuas, o que sugere, igualmente, uma datação anterior aos anos $3 / 2$ a. C. para as operações de limitatio da nova cidade e para $o$ início do povoamento da área urbana da cidade romana.

Neste contexto, parece legítimo considerar que Bracara Augusta representa, para já, a única cidade do NO, cujos dados epigráficos se coadunam em termos de cronologia com os vestígios arqueológicos disponíveis, que atestam uma ocupação efetiva da cidade anteriormente à transição da Era, o que permite admitir que a sua fundação tenha sido decidida entre 16 e 13 a. C. Por outro lado, à luz dos dados disponíveis, a cidade parece ter tido uma origem claramente civil, tendo o seu povoamento sido iniciado anteriormente a 3 a. C., certamente com uma forte componente indígena de base regional, bem documentada no dossier epigráfico bracarense ${ }^{12}$, bem como pela cerâmica de produção indígena, representada em níveis construtivos datados

\footnotetext{
${ }^{6}$ SEVILLANO FUERTES, 2014.

${ }^{7}$ CARREÑO GASCON \& RODRIGUEZ COLMENERO, 2012.

${ }^{8}$ VILLANUEVA ACUÑA, 2016.

${ }^{9}$ TRANOY, 1981.

${ }^{10}$ MARTINS \& CARVALHO, 2016.

${ }^{11}$ REDENTOR, 2011: n. ${ }^{\text {os }} 153,153,154,160,161$.

12 TRANOY \& LE ROUX, 1989-90; REDENTOR, 2011.
} 
do século I, mas ausente dos contextos fundacionais das estruturas atribuídas ao período de Augusto. Esta circunstância permite contrariar, em absoluto, a hipótese de que a cidade possa ter sucedido a um povoado indígena, documentando antes que a cidade foi fundada ex novo, à semelhança do que parece ter acontecido com Lucus Augusti e Asturica Augusta, apesar desta última ter conhecido um acampamento militar anterior ao seu desenvolvimento urbano.

Assim, pode afirmar-se que os locais escolhidos para sedear as três capitais conventuais tiveram em conta uma clara intenção de criar novas centralidades políticas, rompendo com a lógica do povoamento indígena anterior, o que pode ser explicado em termos estratégicos, uma vez que boa parte do povoamento das novas cidades foi feita pelos indígenas originários dos povoados pré-romanos, cujas elites terão certamente negociado a sua posição no corpo cívico dos novos núcleos urbanos. Por outro lado, reconhece-se a existência de povoados indígenas quer nas imediações Lucus Augusti, quer de Bracara Augusta, com destaque no último caso para o Castro Máximo, situado cerca de $2 \mathrm{~km}$ em linha reta do centro da cidade romana ${ }^{13}$.

Sem dúvida que na escolha da localização para fundar as sedes administrativas do NO terá pesado a centralidade territorial que as mesmas deveriam possuir, articulada com a sua proximidade relativamente a corredores naturais terrestres e fluviais, facilitadores das comunicações, indispensáveis ao desenvolvimento das futuras cidades ${ }^{14}$. Mas, para além daquilo que pode parecer comum às três capitais conventuais, como seja a sua fundação ex novo, a sua centralidade e fácil acessibilidade, ou as suas funções como centros administrativos, económicos e religiosos, importa destacar que cada uma dessas cidades carece de ser entendida, na sua fundação, tal como na sua evolução, no quadro dos contextos culturais pré-romanos específicos das regiões em que se implantaram.

Bracara Augusta será porventura a cidade cujo enquadramento pré-romano é melhor conhecido ${ }^{15}$, dispondo-se igualmente de uma boa base arqueológica para a caracterização do território no período romano ${ }^{16}$, sendo por isso possível compreender as dinâmicas que presidiram à fundação da cidade, bem como os impactos decorrentes da criação dessa nova realidade ${ }^{17}$. Na verdade, não podemos esquecer que as cidades romanas são impensáveis sem uma inerente articulação com os seus territórios, pela natureza da própria cidade antiga, que integrava um centro urbano e um território do qual dependia e que administrava, constituindo ambas realidades a base da ordenação territorial romana, que dava expressão à ideia e à prática política

\footnotetext{
${ }^{13}$ CARVALHO, 2008.

${ }^{14}$ DOPICO CAÍNZOS, 2016.

${ }^{15}$ MARTINS, 1990; CARVALHO, 2008.

${ }^{16}$ CARVALHO, 2008.

${ }^{17}$ MARTINS \& CARVALHO, 2016.
} 
de organizar e administrar o Império. Neste sentido, a compreensão dos processos históricos das novas cidades romanas tem que ser esboçada no quadro das dinâmicas sociopolíticas, económicas e culturais das regiões em que foram fundadas.

Assim, reconhece-se hoje que o precoce contacto da região ocidental da área galaico bracarense com os exércitos romanos e a sua aparente pacificação, associada a uma reconhecida hierarquização do povoamento no século I a. C., terão porventura reforçado a especificidade cultural desta região meridional do NO peninsular relativamente às regiões mais setentrionais e interiores ${ }^{18}$. Com efeito, este território possui traços culturais distintivos, particularmente percetíveis na estruturação de um povoamento claramente hierarquizado, encabeçado por oppida, com uma organização ortogonal das áreas residenciais, a que acrescem outros elementos culturais diferenciadores, como sejam a prática de colocar estátuas de guerreiros em pontos destacados das muralhas, que se supõe relacionada com processos de afirmação identitária das comunidades, bem como de uma elite emergente, que se afirmaria também através de uma linguagem decorativa própria, bem expressa na ornamentação dos balneários rituais e das portas de algumas casas ${ }^{19}$.

O inegável protagonismo assumido pelos indígenas na vida económica e na estrutura social de Bracara Augusta, bem testemunhado no registo epigráfico, parece demonstrar que a sua criação se deveu a uma decisão política consensual entre Roma e as elites indígenas bracarenses, a qual terá sido precisada com os necessários instrumentos jurídicos e administrativos romanos, que se projetaram no território através de rituais e cerimónias específicas, próprias da tradição fundacional romana de criação de novas ciuitates. Somente após esses procedimentos se terão realizado os necessários trabalhos de agrimensura, certamente anteriores ao processo de povoamento da área urbana e das atividades construtivas que estariam certamente já em desenvolvimento quando Paulus Fabius Maximus se deslocou à cidade, entre 3/2 a.C. e tomou parte da homenagem que os bracaraugustani prestaram a Augusto.

\subsection{O modelo urbano de Bracara Augusta}

Muito embora a informação textual e epigráfica relativa ao estatuto de Bracara Augusta se mantenha silenciosa, a verdade é que o registo arqueológico demonstra que a cidade e o território terão conhecido um conjunto de procedimentos muito semelhantes aos que foram ensaiados e consolidados na Itália tardo republicana, no contexto de novas fundações coloniais, que permitiam a materialização no espaço de novas cidades e a delimitação dos respetivos territórios. Por isso, independentemente do estatuto jurídico de Bracara Augusta temos razões para acreditar que as

\footnotetext{
${ }^{18}$ GONZALEZ RUIBAL, 2006-07.

${ }^{19}$ SILVA, 1999.
} 
operações cadastrais realizadas no território, bem como a delimitação e subdivisão da área urbana em nada se diferenciaram daquelas que se conhecem para as fundações coloniais ex novo. A principal diferença reside no facto de Bracara Augusta não ter sido criada para implantar colonos, mas sim para instalar uma população que deveria deter estatutos diferenciados, em que se incluíam alguns cidadãos romanos, membros da elite indígena da região e um número considerável de peregrinos de diferentes regiões da Hispânia.

Nada sabemos sobre os rituais fundacionais de Bracara Augusta, ou mesmo sobre a data em que os mesmos terão ocorrido, podendo apenas ser sugerido, com base nos dados arqueológicos e epigráficos, que os mesmos deveriam ter tido

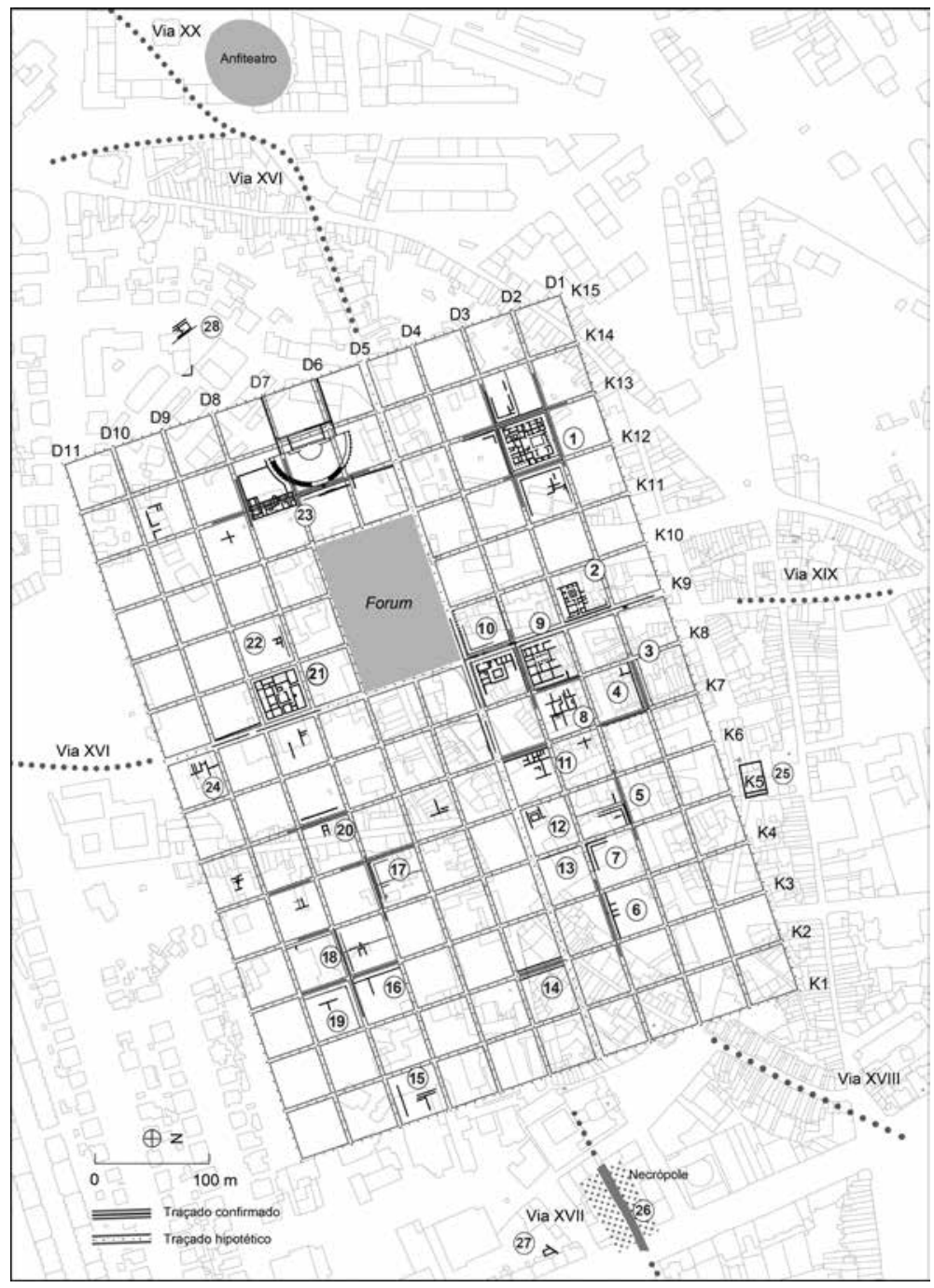

Fig. 2.

Restituição da malha urbana e do sistema viário com base nas zonas arqueológicas interpretadas. 
lugar anteriormente ao ano 3/2 a. C. Já o processo de materialização dos limites e a subdivisão do espaço físico da nova cidade pode ser inferido a partir dos dados arqueológicos, sendo possível estimar que teria o seu eixo maior no sentido E/O e uma área planificada mínima de cerca de 29.85 ha $^{20}$. Por outro lado, a valorização conjunta dos elementos determinantes da morfologia urbana, designadamente, o sistema viário, ou os seus indicadores mais diretos, como sejam pavimentos, limites de pórticos, cloacas, ou as áreas construídas dos quarteirões, forneceu-nos a base para restituir o módulo usado na marcação da cidade. Assim, os vestígios construtivos documentam que a cidade possuía uma orientação NNO/SSE, apresentando um desvio de $16^{\circ}$ relativamente ao norte, sendo a distância medida entre os eixos das ruas conhecidas de 156 pés $(46.20 \mathrm{~m})$, quer no sentido N/S, quer no sentido E/O, facto que sugere um modelo planimétrico baseado no cruzamento de dois eixos principais, com subsequente marcação de eixos paralelos, que definiam uma grelha quadrada. A equidistância de 156 pés entre o eixo das ruas define um módulo regular para as áreas construídas dos quarteirões e das ruas.

Sabe-se que o cardo máximo, que acompanharia o limite nascente do forum, apresentava uma largura de 7.24 m (24 pés), enquanto as ruas secundárias oferecem uma largura média de 12 pés, valor que se repete na largura dos pórticos anexos, que constituíam elementos das fachadas das casas, funcionando como espaços de articulação do sistema viário com as áreas construídas dos quarteirões. Deduzindo o valor das ruas e pórticos à medida de 156 pés é possível apurar que os lotes de construção tinham 120 pés de lado, o que corresponde a áreas de 1 actus (35.52 m x $35.52 \mathrm{~m}$ ), unidade de medida amplamente usada pelos agrimensores nas cidades. A dimensão dos lotes residenciais apenas variava nos quarteirões limítrofes do cardo máximo, onde as áreas reservadas à construção seriam ligeiramente menores (120 x 114 pés $=35.52 \mathrm{~m}$ x $33.74 \mathrm{~m}$ ), devido à maior largura daquele eixo viário, sendo presumível que o mesmo tenha ocorrido com os quarteirões anexos ao decumano máximo, situação que ainda não foi arqueologicamente comprovada. De facto, o decumano principal constitui o eixo viário pior documentado, presumindo-se que possa estar fossilizado, no seu segmento poente, na atual rua de S. Sebastião, enquanto no lado nascente coincidia com a orientação da via XVII, documentada numa extensão considerável na parte nascente da cidade.

Testemunho inequívoco do início do povoamento da cidade são os trabalhos de implantação da via XVII e os primeiros enterramentos da necrópole a ela associada ${ }^{21}$. Assim, pode considerar-se que o povoamento, bem como o arranque das atividades construtivas deverão ter-se desenvolvido ao longo da última década do século I a. C.,

\footnotetext{
${ }^{20}$ Desconhecem-se ainda com exatidão os limites ocidentais e meridionais da área planificada.

${ }^{21}$ BRAGA, 2010.
} 

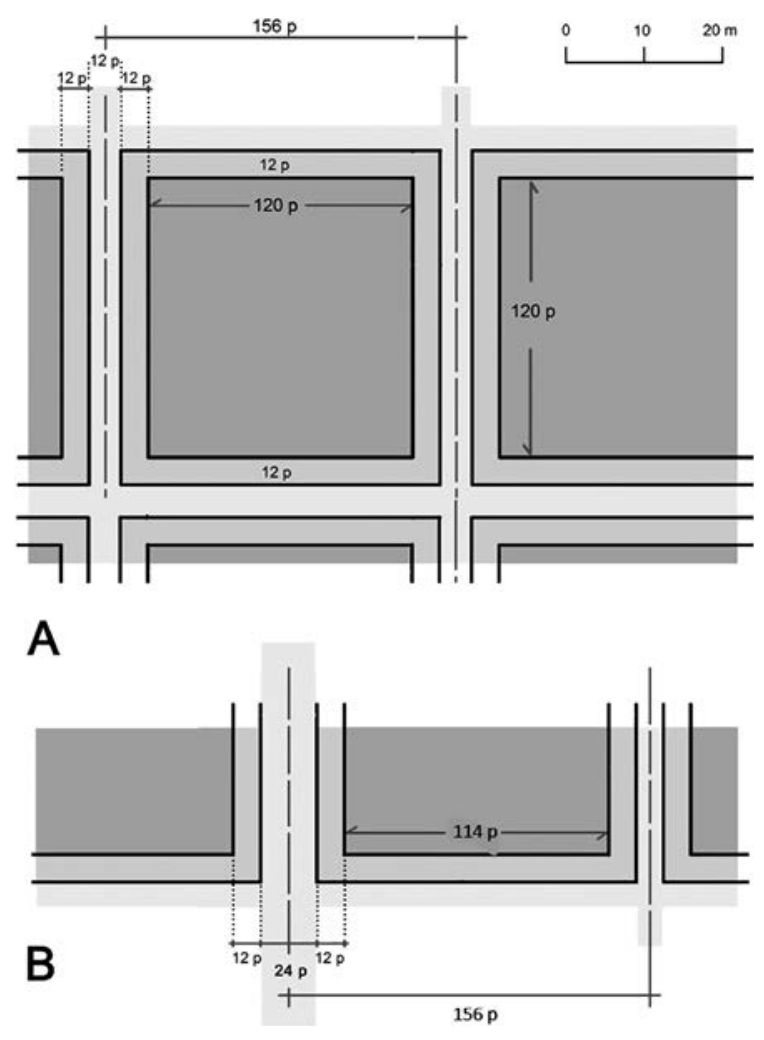

Fig. 3.

Proposta do módulo da malha urbana fundacional de Bracara Augusta. A. Módulo corrente. B. Módulo dos quarteirões limítrofes do cardo máximo.

muito embora sejam escassos os vestígios arquitetónicos que podem ser seguramente reportados a esses anos. Certamente que nesse período ter-se-ão iniciado as atividades construtivas associadas ao forum, que terão exigido uma considerável mão-de-obra indígena, sendo de destacar a abundância de materiais arqueológicos que documentam uma intensa ocupação da área circundante daquele espaço cívico nas primeiras décadas de vida da cidade. No entanto, nada sabemos sobre a estrutura daquele centro administrativo e religioso. Pelo contrário podemos atribuir ao período de Augusto alguns silhares que marcavam os limites dos quarteirões, alguns muros de contenção, construídos em aparelho poligonal de tradição indígena, bem como um invulgar espaço construído, identificado na Colina do Alto da Cividade, cujas características sugerem a sua possível função como espaço comercial ${ }^{22}$. No entanto, a imagem que podemos recriar da cidade de Augusto e Júlio Claúdia em nada se assemelha à da cidade do século II, pois datam já de um período avançado, entre finais do século I e os inícios do II, alguns dos principais equipamentos públi-

22 MARTINS, 2005. 
cos reconhecidos pela arqueologia, que representavam imprescindíveis ornamenta de qualquer cidade romana provincial. Entre eles destacam-se o teatro, o anfiteatro, cuja localização é conhecida e vários edifícios termais de carácter público ${ }^{23}$. Este programa de monumentalização da cidade teve, nalguns casos, implicações urbanísticas significativas, designadamente ao nível da desafetação de eixos viários e do arrasamento de edifícios anteriores, como aconteceu com a construção do teatro ${ }^{24}$. Por outro lado, o impacto desta fase de monumentalização terá feito desaparecer muitas das evidências associadas à urbanização que terá caracterizado a cidade entre o período de Augusto e a época flávia.

Apesar das inúmeras lacunas relativas a um significativo conjunto de quarteirões residenciais, conhecem-se numerosos vestígios arqueológicos de domus ${ }^{25}$, construídas a partir de meados do século I. Julgamos mesmo poder articular o processo de urbanização dos quarteirões com a implantação da grande cloaca, que corria sob o cardo máximo, construída entre os reinados de Cláudio e Nero. A generalidade dos dados disponíveis sugere que as casas de elite se estruturavam em função de um peristilo, sendo contudo possível que os átrios fossem também comuns como elementos distribuidores dos espaços das habitações de elite.

Os conhecimentos relativos à periferia da cidade são fragmentários, mas bem sugestivos da organização das áreas envolventes da parte planificada. $\mathrm{Na}$ verdade, tomando por referência o século II, é possível percecionar uma periferia densamente ocupada, onde pontuavam edifícios públicos, como o anfiteatro e um eventual foro comercial, que se situaria a nordeste e que integraria um macellum e um eventual templo a Isis ${ }^{26}$, para além de santuários ${ }^{27}$, áreas artesanais, necrópoles ${ }^{28}$ e outros edifícios de difícil caracterização. No seu conjunto, os dados disponíveis revelam uma periferia intimamente relacionada com a área planificada, cuja importância justificou a sua inclusão no perímetro intramuros da cidade quando esta foi fortificada por uma robusta muralha nos finais do século III/inícios do $\mathrm{IV}^{29}$.

\section{CONSIDERAÇÕES FINAIS}

O esforço de análise comparativa dos modelos urbanos das três capitais conventuais do NO peninsular depara-se com sérias dificuldades, considerando, não só a diferencial morfologia das três cidades, como o desigual conhecimento que delas possuímos relativamente à restituição das malhas fundacionais. $\mathrm{Na}$ verdade, nada

\footnotetext{
${ }^{23}$ MORAIS 2001; MARTINS et al., 2013.

${ }^{24}$ MARTINS et al., 2013.

${ }^{25}$ MAGALHÃES, 2010.

${ }^{26}$ FONTES et al., 1997-98.

${ }^{27}$ ELENA et al., 2008.

${ }^{28}$ MARTINS \& DELGADO, 1989-90; BRAGA, 2010.

${ }^{29}$ LEMOS et al., 2007.
} 
de semelhante parece existir entre a regularidade dos quarteirões e ruas de Bracara Augusta e a diferencial dimensão dos lotes que conformam os quarteirões de Asturica Augusta. Aparentemente, essa regularidade contrasta também com os dados disponíveis para Lugo, onde não se logrou restituir ainda a morfologia dos quarteirões romanos, referidos como sendo de grandes dimensões, pelo que poderiam albergar várias $\operatorname{casas}^{30}$.

Do modelo urbano de Bracara Augusta, muito rígido e geométrico, com áreas construtivas de 1 actus, pode inferir-se um corpo cívico pouco hierarquizado e um ambiente social bem menos competitivo do que aquele que certamente existiria em Asturica Augusta, onde conviveriam vários tipos de elites, umas mais ligadas à administração das minas, com destaque para os membros da ordem senatorial e equestre que estão representados no contexto epigráfico e outras certamente associadas às funções da cidade enquanto capital de convento jurídico, que presumivelmente incorporariam elementos da aristocracia indígena. Por isso, julgamos que a desigual repartição do espaço urbano entre áreas públicas e privadas nas três cidades, tendo por base uma prévia definição dos corpos cívicos das cidades, evidencia aspetos que estarão relacionados com as suas funções administrativas, mas também com as prévias características dos territórios em que foram fundadas. Neste contexto, julgamos de reforçar a especificidade de Bracara Augusta, desde logo relacionada com a sua fundação civil, talvez à semelhança de Lucus Augusti, mas também com o protagonismo que as elites indígenas tiveram no povoamento e constituição do corpo cívico da cidade, facto que terá resultado do contexto político, socioeconómico e cultural que caracterizaria a região bracarense anteriormente à sua integração no Império. De resto, o protagonismo das elites indígenas, bem documentado no corpus epigráfico da área urbana, é igualmente percetível no território, pois parecem terem sido elas, ou os seus descendentes, os detentores das uillae que começaram a ser monumentalizadas a partir da época flávia, tendo certamente beneficiado da organização cadastral que se implantou, na época de Augusto e que cobria as ricas veigas que envolviam a cidade ${ }^{31}$.

Assim, julgamos ser imprescindível compreender os modelos urbanos das cidades do NO da Hispânia no contexto mais amplo dos territórios em que se implantaram, sob pena de jamais entendermos as suas especificidades, quer físicas, quer socioeconómicas. Por outro lado, é forçoso que a compreensão dessa realidade seja aprofundada no quadro de programas de investigação mais cooperativos, que esbatam as fronteiras geográficas e disciplinares, mas também a heterogeneidade dos procedimentos com que a arqueologia encara os seus objetos de estudo. A definição

\footnotetext{
${ }^{30}$ CARREÑO GASCON \& RODRIGUEZ COLMENERO, 2012.

${ }^{31}$ CARVALHO, 2008; MARTINS \& CARVALHO, 2016.
} 
e adoção de objetivos e protocolos de investigação arqueológica comuns no estudo das cidades romanas, mas também dos seus territórios, seria a este propósito fundamental, pois a sua análise comparativa exige níveis de inteligibilidade semelhantes, independentemente dos diferentes graus de aprofundamento das pesquisas.

\section{BIBLIOGRAFIA}

BRAGA, C. (2010) - Rituais funerários em Bracara Augusta: o novo núcleo de necrópole da Via XVII. Braga: UAUM. Tese de Mestrado.

CARREÑO GASCÓN, A.; RODRÍGUEZ COLMENERO, A. (2012) - La trama urbanística de Lucus Augusti. Génesis y evoluión. In Hispaniae Urbes. Investigación arqueológica en ciudades históricas. Sevilha, p. 295-318.

CARVALHO, H. (2008) - O povoamento romano na fachada ocidental do Conventus Bracarensis, Braga: UMinho. Tese de Doutoramento.

DOPICO CAÍNZOS, M. D. (1986) - Los conventus iuridici. Origem, cronologia y naturaleza histórica. «Gérion», 4, p. 265-283.

(1988), La Tabula Lougeiorum. Estudios sobre la implantación romana en Hispania. Vitoria.

(2009) - A transformação dos pobos do noroeste hispánico na época de Augusto: a evidencia epigráfica. In Do castro á Cidade. A romanización na Gallaecia e na Hispânia indoeuropea, Lugo, p. 31-53. (2016) - Os inícios da urbanización no Noroeste: as capitales conventuais. In Clausus est Ianus. Augusto e a transformación do noroeste hispano. «Philtáte», 1, Lugo: Deputación de Lugo, p. 259-284.

ELENA, A.; MAR, R.; MARTINS, M. (2008) - A Fonte do Idolo: análise, interpretacão e reconstituicão do santuário. Braga: UAUM.

FONTES, L.; LEMOS, F.S.; CRUZ, M. (1997-98) - 'Mais Velho' que a Sé de Braga. Intervenção arqueológica na catedral bracarense: notícia preliminar. "Cadernos de Arqueologia», 14/15, p.137-164.

GONZÁlEZ RUIBAL, A. (2006-07) - Arqueología del Primer Milenio en el Noroeste de la Península Ibérica. A Coruña.

LEMOS, F. S.; LEITE, J. M. F.; CUNHA, A. (2007) - A muralha romana (Baixo Império) de Bracara Augusta. In Actas del Congreso Internacional Murallas de ciudades romanas en el Occidente del Imperio. Lucus Augusti como paradigma. Lugo, p. 329-341.

LE ROUX, P. (1994) - Bracara Augusta, ville latine. «Trabalhos de Antropologia e Etnologia», 34 (1-2), p. $229-241$.

(2004) - La question des conuentus dans la péninsule Ibérique d'époque romaine. In Au jardin des Hespérides: Histoire, societé et épigraphie des mondes anciens. Mélanges offerts à Alain Tranoy. Rennes: P. U. de Remes, p. 337-356.

MAGALHÃES, F. (2010) - Arquitectura doméstica em Bracara Augusta. Braga: UMinho. Tese de Mestrado.

MARTINS, M. (1990) - O povoamento proto-histórico e a romanização da bacia do curso médio do Cávado. Braga: UAUM.

(2005) - As termas romanas do Alto da Cividade. Um exemplo de arquitectura pública em Bracara Augusta. Braga: UAUM.

MARTINS, M.; CARVALHO, H. (2016) - As transformações do território: Bracara Augusta e o seu cadastro. "Revista de Historiografía», 25, p. 219-243.

MARTINS, M.; MAR, R.; RIBEIRO, J.; MAGALHÃES, F. (2013) - A construção do teatro romano de Bracara Augusta. In MELO, Arnaldo Sousa; RIBEIRO, Maria do Carmo, coord. - História da Construção. Arquiteturas e técnicas Construtivas. Braga: CITCEM, p. 41-76. 
MARTINS, M.; DELGADO, M. (1989-90) - As necrópoles de Bracara Augusta. A. Os dados arqueológicos. "Cadernos de Arqueologia», 6/7, Braga, p. 41-186.

MORAIS, R. (2001) - Breve ensaio sobre o anfiteatro de Bracara Augusta. «Forum», 30, p. 55-76.

REDENTOR, A. (2011) - A cultura epigráfica no Conventvs Bracaravgvstanvs (Pars Occidentalis). Percursos pela sociedade brácara da época romana. Coimbra: Universidade de Coimbra. Tese de Doutoramento.

SALINAS DE FRIAS, M. (2001) - Dion Cassio, la Transduriana provincia y la evolución del ordenamento augústeo de Hispania. In El bonce de Bembibre. Un Edicto del emperador Augusto del año 15 a.C. León: Museo de León, p. 135-146.

SEVILLANO FUERTES, M. A. (2014) - Apuntes arqueológicos para la historia antigua de Astorga. Astorga: CEAMM.

SILVA, A. C. F. (1999) - A ocupação do território do Noroeste Peninsular aquando da chegada dos romanos. In Actas da Mesa-Redonda Emergência e Desenvolvimento das cidades romanas no Norte da Península Ibérica. Porto: Escola Profissional de Arqueologia; Instituto Português do Património Arquitectónico, p. 39-52.

TRANOY, A. (1981) - La Galice romaine. Recherches sur le Nord-Ouest de la Péninsule Ibérique dans l'Antiquité. Paris: De Boccard.

TRANOY, A.; LE ROUX, P. (1989-90) - As necrópoles romanas de Bracara Augusta - Les inscriptions funéraires. «Cadernos de Arqueologia», 6-7, Braga, p. 183-230.

VILLANUEVA ACUÑA, Manuel (2011) - Problemas en torno a la organización administrativa del Noroeste en los inícios del Imperio. "Historia Antigua», XXXV, p. 67-82.

(2016) - La fundación de Lucus Augusti: nuevas perspectivas. «Revista de Historiografía», 25, p. 273-286. 



\title{
ARQUEOLOGÍA Y DESARROLLO \\ URBANÍSTICO EN TRES NÚCLEOS \\ INDÍGENA-ROMANOS: \\ CAUCA, SEGOVIA Y TERMES
}

\author{
CESÁREO PÉREZ GONZÁLEZ* \\ PABLO ARRIBAS LOBO**
}

Cauca, Segovia y Termes son enclaves representativos de la Antigüedad en la submeseta norte de la Península Ibérica, localizados al sur de la cuenca fluvial del río Duero, fundamentales para comprender el proceso de evolución de los oppida o ciuitates en esta área geográfica. Los tres se superponen a asentamientos preexistentes y disponen de restos arqueológicos suficientes para reflexionar sobre ellos, contando además con algunas referencias clásicas que han llegado hasta nosotros. No obstante, no resulta sencillo analizar y comparar su respectiva documentación arqueológica, ya que la investigación referida a los mismos no es coincidente en tiempo ni en volumen, así como tampoco en la seriedad y profundidad de los trabajos dedicados a cada uno.

Las fuentes escritas conservadas aportan datos sobre diferentes acontecimientos político-militares, así como información geográfica y de carácter económico y social, que han motivado la construcción de hipótesis acerca de los sucesos acontecidos en este territorio y el papel jugado en ellos por sus habitantes por parte de las distintas escuelas historiográficas. Estos testimonios no siempre son coincidentes con los datos proporcionados por la arqueología, aunque en ocasiones se haya puesto empeño en ello con mucha insistencia; por ello entendemos que el estudio

\footnotetext{
* IE Universidad. cesareo.perez@ie.edu.

** IE Universidad. pablo.arribas@ie.edu.
} 
detenido de las distintas familias de materiales arqueológicos (cerámica, vidrio, numismática, metales, etc.) es fundamental para el establecimiento de propuestas apropiadas de reconstrucción histórica. Las excavaciones arqueológicas realizadas en estos yacimientos muestran una intensa y cambiante secuencia urbana y cultural, reflejo de sucesivas coyunturas económicas, políticas y sociales que pueden seguirse mediante el análisis de contextos, refacciones y cambios de utilidad atestiguados en sus espacios habitados.

Una vez establecidas estas premisas iniciales, vamos a intentar realizar una aproximación comparativa entre estos yacimientos, que pueden singularizarse de manera tanto diacrónica como sincrónica, a partir de una síntesis de los datos arqueológicos que disponemos para cada uno de ellos.

\section{CAUCA}

El núcleo principal de este enclave se localiza sobre un espigón fluvial delimitado por los ríos Eresma y Voltoya, y en él se documenta la presencia humana al menos desde fechas calcolíticas, a partir del hallazgo de algunos artefactos relacionados con este período. Desde entonces, el sector de los Azafranales será sede temporal o estacional de diversas comunidades de la Edad del Bronce, hasta registrar el primer asentamiento de carácter permanente en la Primera Edad del Hierro, y aunque no se han constatado evidencias de unidades de habitación asignables a este período, La excavación de 1999 en Los Azafranales revela un horizonte de estas características adscrito a la facies Soto de Medinilla y parte de la transición al Hierro II, datado entre los siglos VII-V a. C., en el que se produjo el hallazgo de una singular joya áurea perteneciente al Bronce Final atlántico ${ }^{1}$.

Se estima que la extensión de esta primera ocupación protourbana debió rondar las 1,5-2 hectáreas y se ha detectado un sector de la necrópolis de incineración asociada a esta Primera Edad del Hierro (siglo VI-inicios del V a. C.) a consecuencia de la realización en 1993 de una zanja para el colector municipal. En fechas similares se constata la ocupación del Castro de la Cuesta del Mercado, localizado a unos 600 metros al norte del casco urbano actual, que al parecer es abandonado a mediados del siglo I a. C. ${ }^{2}$. Por otro lado, conocemos en Coca la presencia de al menos tres ejemplares de esculturas zoomorfas, conservadas dos de ellas junto a la puerta de la villa y otra empotrada en el aparejo que delimita el foso del castillo mudéjar ${ }^{3}$.

\footnotetext{
${ }^{1}$ PÉREZ GONZÁLEZ \& BLANCO GARCÍA 2000: 40-41; BLANCO GARCÍA \& PÉREZ GONZÁLEZ, $2010-2011$.

2 BLANCO GARCÍA, 2002: 132, 143.

${ }^{3}$ Cauca y Segovia constituyen algunos de los puntos más orientales donde se documenta la presencia de verracos, y en Termes ya no se tiene constancia de la presencia de este tipo escultórico característico de la Segunda Edad del Hierro (y ampliamente aprovechado en época romana), cuya localización se concentra en territorio atribuido por las fuentes clásicas a los vetones - Meseta occidental, Tras-os-Montes y parte de Extremadura-. Con ello, observamos
} 


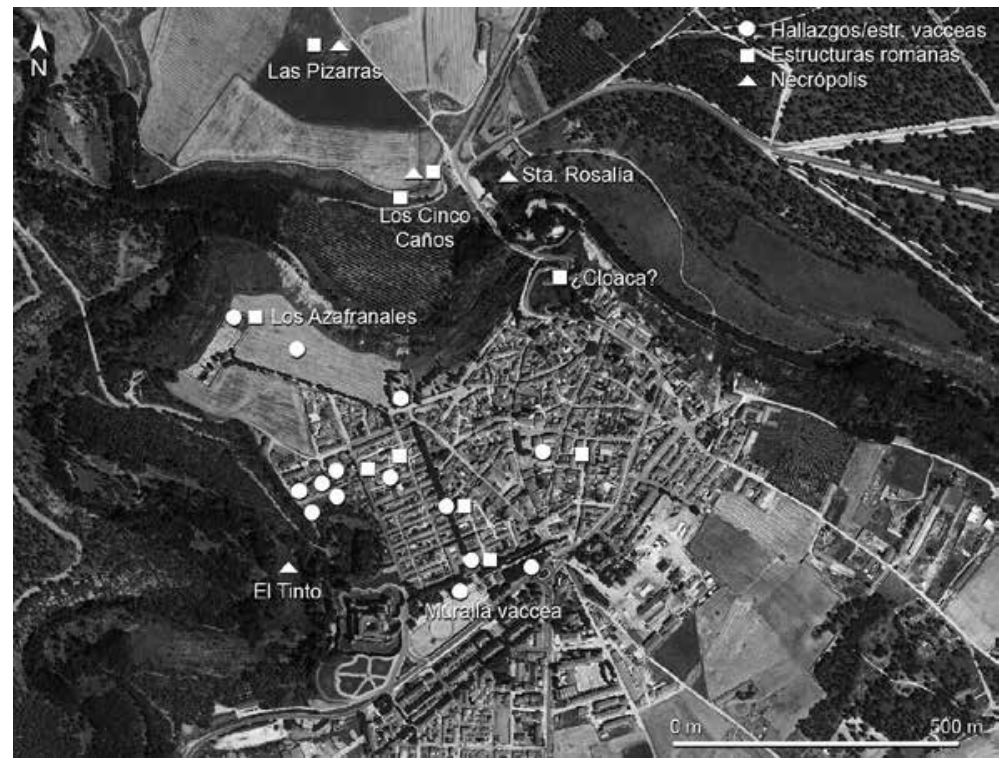

Fig. 1.

Estructuras y hallazgos arqueológicos más relevantes en Coca. (PNOA, 2014).

Ya en época vaccea, los resultados derivados de las excavaciones muestran una trama urbana organizada en manzanas de casas adosadas de planta cuadrada o rectangular ${ }^{4}$. De su arquitectura doméstica, caracterizada gracias a la información aportada por la campaña de 1999 en el espacio de Los Azafranales, podemos indicar el empleo exclusivo de adobe y tapial para la construcción de las viviendas, con cubiertas vegetales y pavimentos de arcilla apisonada, en los que se observan renovaciones de áreas puntuales ${ }^{5}$. Respecto a las instalaciones artesanales, conocemos la existencia de un complejo alfarero documentado en 1989-1990 en el límite suroccidental del espigón fluvial, en la denominada Tierra de las Monedas, consistente en varios hornos y estancias relacionadas con la elaboración y almacenaje de cerámica a mano y a torno, que sería abandonado a mediados del siglo III a. C. ${ }^{6}$.

Tenemos constancia de que Cauca estuvo protegida por una muralla en sus lados sur y este ${ }^{7}$, contando con la protección natural de los cortados hacia el curso de los ríos Voltoya y Eresma en los otros flancos. En 2011, con motivo de unas obras municipales en el graderío del antiguo campo de fútbol, se puso al descubierto una estructura que posteriormente sería interpretada como la muralla de esta ciudad vaccea, y en la que se realizaría un intervención arqueológica en 2014, permitiendo la

\footnotetext{
la progresiva desaparición del influjo que denotan estas manifestaciones culturales a medida que nos aproximamos al alto Duero, ocupado por grupos de raigambre celtibérica.

${ }^{4}$ PÉREZ GONZÁLEZ \& REYES HERNANDO, 2007: 153.

${ }^{5}$ BLANCO GARCÍA, 2016: 53-57.

${ }^{6}$ BLANCO GARCÍA, 1992.

${ }^{7}$ APP., Iber., 52.
} 
definición de sus características básicas en un segmento de casi 17 metros lineales: un basamento de piedra formado por lajas de pizarra y cuarcitas, y un alzado de adobes de módulos variables. La cronología que se ha propuesto para el levantamiento de este paramento se estima en la segunda mitad del siglo IV a. C.-principios del siglo III a. C., en base a sus características arquitectónicas y los materiales cerámicos recuperados en el interior de su aparejo ${ }^{8}$.

Los restos romanos de época republicana y altoimperial se limitan a escasas acuñaciones augusteas, representadas desde el 36 a. C. al 12 d. C., y varios glandes de plomo. En cerámica tan sólo conocemos algunos fragmentos de cerámica de barniz negro - Cuesta del Mercado, Azafranales...- y un único ejemplo de terra sigillata itálica -Consp. 23- de época de Tiberio-Claudio9. También son escasos por ahora los datos arqueológicos atribuibles al proceso de cambio sufrido en la articulación urbanística de Cauca en su etapa altoimperial, y sus evidencias constructivas se reducen a aislados ejemplos, como un muro documentado en la Avda. de la Constitución esqu./ con calle Azafranales, con restos de estucos pintados asociado a tipos cerámicos de finales del II d. C., u otras estructuras aparecidas en la calle Falcón Ruiz o Los Azafranales, donde fueron exhumados los restos de la esquina de un edificio, registrando el arranque de sus muros y un derrumbe de tapial con estucos pintados ${ }^{10}$.

A mediados del siglo I d. C., Cavca es mencionada como ciudad vaccea ${ }^{11}$. No obstante, no parece que su núcleo urbano haya sido objeto de programas de monumentalización o transformaciones urbanísticas en época altoimperial por parte de Roma ${ }^{12}$, y desconocemos la ubicación y el carácter de sus espacios públicos como el foro, cuya localización ni siquiera se intuye debido a la limitada visión que disponemos del panorama urbanístico caucense, en cuyo solar no se han identificado hasta el presente grandes edificaciones ni infraestructuras de entidad suficiente como para ser caracterizadas en este sentido.

La integración de las comunidades estipendiarias en la estructura estatal se promueve mediante la aplicación de estatutos de municipalidad que confieren el derecho de ciudadanía romana a sus habitantes ${ }^{13}$. En el caso de Cauca, gracias a la Tabula de Montealegre, que refrenda en el $134 \mathrm{~d}$. C. un hospitium anterior, conocemos que la

\footnotetext{
${ }^{8}$ BLANCO GARCÍA, 2014.

${ }^{9}$ BLANCO GARCÍA, 1987; BLANCO GARCÍA, 2010: 227; BLANCO GARCÍA, 2003: figs. 31-1/4.

${ }^{10}$ BLANCO GARCÍA, 2002: 148; BLANCO GARCÍA et al., 2012-2013: 63-64.

${ }^{11}$ PLIN., Nat., 3.26.

12 BLANCO GARCÍA, 2011: 94.

${ }^{13}$ Con seguridad, cada uno de estos núcleos contaría con una clase dirigente local, formada por personas procedentes de instituciones indígenas a las que se unirían latinos conocedores de las estructuras políticas imperiales; estas elites serían las solicitantes de la promoción jurídica de las ciuitates, ajustándose a un protocolo dentro del cual el aparato jurídico romano evaluaría tanto su adaptación a las formas de la vida romana como la prestación a Roma de determinados servicios o favores, cuya relevancia aportaba sin duda argumentos de influencia sobre los poderes responsables en la concesión de privilegios.
} 


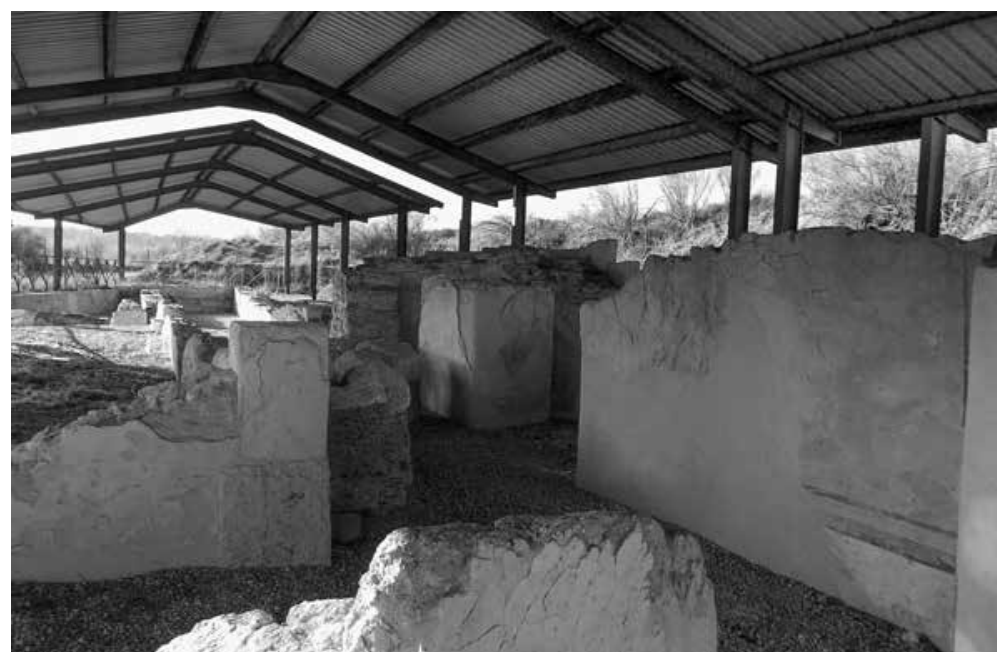

Fig. 2.

Coca, edificio de Los cinco Caños.

ciudad mantenía aún en este momento el rango de ciudad peregrina, según denota el empleo de la fórmula "senatv popvloqve Cavcensivm» ${ }^{14}$. Otro hallazgo epigráfico en bronce que debemos reseñar es un fragmento de placa, presentado como parte de una inscripción de posible carácter público, discutida posteriormente ${ }^{15}$.

Frente a la escasez de datos arqueológicos que se constata en su casco urbano, la Cavca romana altoimperial sorprende con un magnífico conjunto de carácter monumental ubicado en la margen derecha del río Eresma: el edificio de los Cinco Caños, del que no han sido publicados los resultados de su excavación a excepción de notas puntuales ${ }^{16}$. Considerado en un principio como un ninfeo, posteriormente las "opiniones» parecen coincidir en su concepción como una uilla o domvs suburbana, fechada en torno al siglo I-II d. C. A este edificio habría que añadir los nuevos restos documentados en su entorno mediante prospección geofísica, presentados recientemente y en proceso actual de estudio ${ }^{17}$.

Por otro lado, asignables a esta etapa se tiene constancia de varias necrópolis: El Tinto, localizada junto al río Voltoya en la salida suroccidental del centro urbano - el hallazgo de una posible urna de incineración parece indicar su origen en época romana altoimperial, prolongando en el tiempo hasta fechas romanas tardías- y Santa Rosalía, ubicada en las inmediaciones de la ermita del mismo nombre y en la margen opuesta del Eresma, considerada coetánea al inicio de la anterior en base al hallazgo del epígrafe de Sempronia Reburrina, fechado en el siglo II d. C. ${ }^{18}$.

\footnotetext{
${ }^{14}$ BALIL ILLANA \& MARTÍN VALLS coord., 1988.

${ }^{15}$ BLANCO GARCÍA, 2002: 148; SANTOS YANGUAS et al., 2005: 287.

${ }^{16}$ ZAMORA CANELLADA, 1987: 45; BLANCO GARCÍA, 2002: 149; CABAÑERO MARTÍN, 2015: 123-127.

${ }^{17}$ REYES HERNANDO, 2017.

${ }^{18}$ BLANCO GARCÍA, 1987: 17-18; SANTOS YANGUAS et al., 2005: 69.
} 
A partir del Bajo Imperio parece - con la información de carácter arqueológico hoy disponible - que se mantienen los límites de la ciudad altoimperial, aunque desconocemos cualquier evidencia de la existencia de un recinto murario que fortificara la ciudad en este momento. El conjunto edilicio de mayores dimensiones de este período, en el que Cauca es recogida en algunas fuentes como lugar de origen del emperador Teodosio el Grande ${ }^{19}$, lo constituye el edificio de Las Pizarras, ubicado a escasos 500 metros al norte de los Cinco Caños. En función de la inmediata vecindad del núcleo urbano podríamos hablar de una «villa suburbana», constituyendo un complejo de gran extensión y ostentación estructurado en torno a un peristilo rectangular porticado de $4300 \mathrm{~m}^{2}$, que delimitaba un monumental estanque central con una pérgola o isleta octogonal en su interior. En cuanto a su cronología, tanto el estudio de su técnica edilicia, como la planta y la propia arquitectura aportan una cronología centrada en la segunda mitad del siglo IV d. C., con un momento de máximo esplendor entre los años 340-380 d. C., según los restos numismáticos y cerámicos ${ }^{20}$.

Dentro de los elementos de su ornamentación arquitectónica destaca el empleo del mármol -al menos en el patio y las estancias más representativas- dispuesto en forma de opera sectilia sobre paredes y suelos, así como en otros elementos exentos (basas, capiteles, semicolumnas, celosías y barandillas), evidenciando una gran variedad de tipos según su procedencia, en ocasiones vinculada a la explotación de canteras imperiales: Pavonazzetto (Turquía); serpentino (Grecia); pórfido rojo (Egipto); giallo antico (Túnez); Porta Santa (Grecia); Rosso Antico (Grecia); marmor proconesium (Turquía) y ejemplos aislados de marmor lunense (Carrara), mientras que entre los hispanos se distinguen los de Estremoz, Macael y Almadén. Por otro lado, el hallazgo de tesellae de pasta vítrea son indicativo de la presencia de mosaicos ubicados en paredes o bóvedas, y también el nácar desempeñó un papel relevante como elemento decorativo en sus revestimientos parietales ${ }^{21}$.

La fisonomía original de este edificio se vería modificada por diferentes transformaciones secuenciadas. En primer lugar, asistiremos a la reducción del espacio de hábitat y al menoscabo de las salas de representación, perdida su significación original, y a lo largo de un período indeterminado, aunque relativamente corto, se constata en estos ambientes un deterioro notable, traducido en el expolio sistemático de materiales reutilizables y el consecuente abandono de este sector como lugar de residencia. Ahora las áreas de representación se convierten en zonas de vertidos, siendo amortizados en momentos inciertos de inicios del siglo $\mathrm{V} \mathrm{d}$. C., mientras que advertimos la conversión del resto de espacios en lugar de enterramientos, mostrando

\footnotetext{
${ }^{19}$ HYD., Cron. 379; ZOS., Hist. 4, 24.

${ }^{20}$ PÉREZ GONZÁLEZ \& REYES HERNANDO, 2014.

${ }^{21}$ PÉREZ GONZÁLEZ et al., 2012; PÉREZ GONZÁLEZ \& ARRIBAS LOBO, 2016.
} 
una evolución de la arquitectura funeraria desde tipos asignables a las necrópolis del Duero hacia modelos de época visigoda en los siglos VI-VII d. C. ${ }^{22}$.

\section{SEGOVIA}

Situada en el promontorio delimitado por la confluencia de los ríos Eresma y Clamores, Segovia es el claro ejemplo de ciudad antigua subyacente a una ciudad moderna, circunstancia que supone una gran dificultad en la comprensión e interpretación, muy problemática, del urbanismo antiguo segoviano y su evolución a lo largo del tiempo. A. Balil ${ }^{23}$ indicaba hace ya bastantes años que «el estudio de una ciudad requiere un esfuerzo amplio y prolongado, es tarea no personal sino de generaciones y equipos». En el caso de Segovia, como muy bien sintetizó J. F. Blanco ${ }^{24}$, este proceso todavía no se ha producido por variados motivos, y en líneas generales sólo el Acueducto, la epigrafía y la numismática han recibido una cierta atención.

L. Municio, refiriéndose a los «datos arqueológicos sobre la Segovia romana» conocidos entonces decía: "no existen vacíos en las secuencias culturales sino, simplemente, falta o escasez de investigación» ${ }^{25}$. Esta cita, utilizada años antes por Pedro de Palol para reflejar la investigación en la época hispano-romana tardía, sirve para resaltar esta carencia que salvo en casos muy concretos pesa sobre la arqueología segoviana, a falta de estudios monográficos sobre materiales y contextos arqueológicos

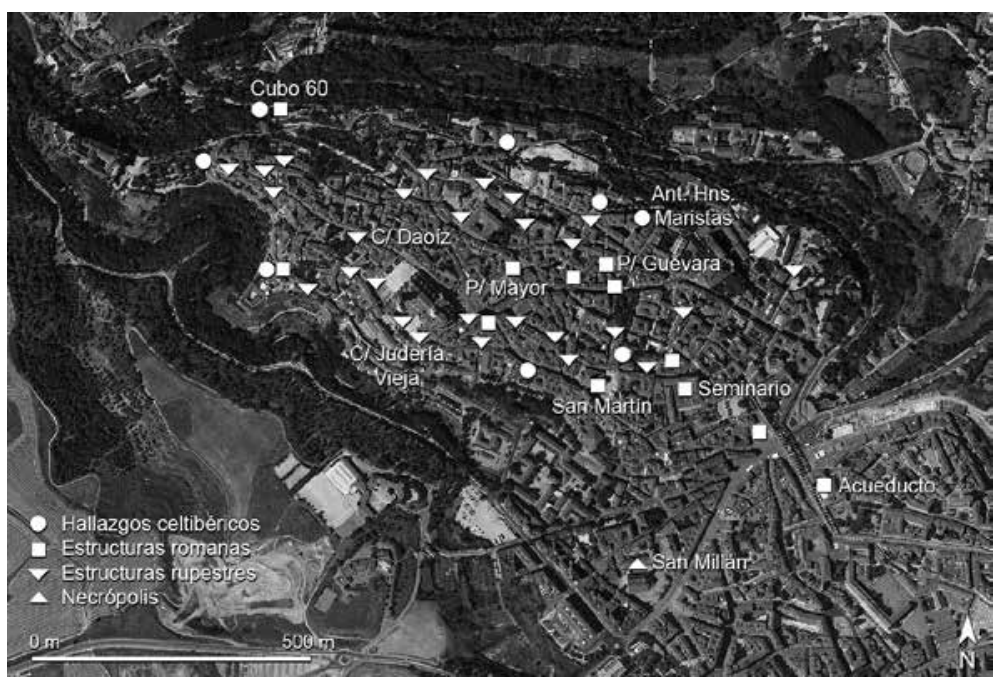

Fig. 3.

Segovia, restos arqueológicos más significativos. (PNOA, 2008).

\footnotetext{
22 PÉREZ GONZÁLEZ \& REYES HERNANDO, 2012; PÉREZ GONZÁLEZ \& REYES HERNANDO, 2017.

${ }^{23}$ BALIL ILLANA, 1986: 543.

${ }^{24}$ BLANCO GARCÍA, 1995.

${ }^{25}$ MUNICIO GONZÁLEZ, 2000.
} 
que permitan sustentar con coherencia las diferentes teorías y propuestas interpretativas que se efectúan sobre la historia de esta ciudad. Precisamente J. Santiago y S. Martínez ${ }^{26}$ han reflexionado sobre «la ciudad de Segovia y su territorio», exponiendo con claridad los pros y contras de la arqueología segoviana y mostrándose optimistas de cara al futuro inmediato.

Se sabe bastante poco de la fase prerromana de Segovia, y se ha recurrido a indicios e informaciones indirectas sobre la aparición de algunos restos, en su mayoría cerámicos, para aproximar su ubicación. Así, la Primera Edad del Hierro se ilustra con materiales descontextualizados procedentes de la Plaza de la Reina Victoria Eugenia y de la Puerta de Santiago, y en el año 1987 todavía no encontramos ninguna referencia a la Segunda Edad del Hierro en el libro Historia de Segovia ${ }^{27}$. También se ha dado noticia de hallazgos celtibéricos en diferentes ubicaciones de su plano, como el antiguo Colegio de los Hermanos Maristas, entre otros ${ }^{28}$, y conocemos - al igual que en la referida Coca- algunos ejemplos de esculturas de verracos conservados en la propia ciudad o en el Museo Arqueológico Nacional.

La excavación arqueológica realizada en 2006 en un solar localizado entre la calle Daoíz y el Paseo de Juan II ha interpretado la presencia de un foso tallado en la roca caliza, de 21 metros de largo, 2,80 de anchura y 4,20 de profundidad. En su colmatación se recuperó un conjunto de materiales cerámicos fechables entre los siglos IV-III y II a. C., momento en el que se data la amortización de esta estructura ${ }^{29}$. A estos datos se ha querido añadir con posterioridad el resultado de una intervención realizada en la calle Velarde, donde se documentó en 1996 parte de otra zanja de 8 metros de longitud y 2,30 metros de profundidad ${ }^{30}$. Sin embargo, las trincheras vaciadas en la roca en determinados espacios de estos oppida no siempre deben de ser interpretadas como fosos, pudiendo tratarse también de drenajes, atarjeas o entalladuras de funcionalidades diversas.

El año 2014 - el mismo en que fue dada a conocer la muralla vaccea de Coca - se presentaban nuevos datos sobre la fortificación celtibérica de Segovia, fruto de una intervención junto al cubo 60 de la muralla medieval ${ }^{31}$. Según sus excavadores, esta construcción significa «una estructura muraria de la fortificación que protegía esta ciudad celtibérica antes de su conquista por Roma, entre 98 y 95 a. C. [...] que protegió la ciudad una vez que en el siglo II a. C. el asentamiento urbano había superado ampliamente el primitivo recinto arcaico». Ésta se habría edificado entre los años 135 y 120 a. C., mientras que «los materiales arqueológicos de los depósitos

\footnotetext{
${ }^{26}$ SANTIAGO \& MARTÍNEZ, 2010: 143-146.

27 ZAMORA CANELLADA, 1987.

28 BLANCO GARCÍA, 2011-2012: 467-477.

${ }^{29}$ MOREDA et al., 2010-2011: 37-44; MARTÍN VELA \& MARCOS HERRÁN, 2010-2011: 45-60.

${ }^{30}$ MARTÍNEZ et al., 2014: 1711.

${ }^{31}$ LABRADOR et al., 2016.
} 
de colmatación de las fosas para la construcción de los muros romanos [...] aportan cronologías entre los siglos I y II d. C.». No obstante, la ubicación de estas estructuras por debajo del cortado rocoso que delimita el cerro por el norte nos hace ser cautos ante esta interpretación, que implicaría el desaprovechamiento de la ventaja defensiva ofrecida por el desnivel topográfico, como sí haría la posterior muralla medieval, emplazada sobre el mismo. Ante estos datos que vamos conociendo pensamos que con la información actual, francamente insuficiente, es prematuro trazar una «breve historia» de la ciudad prerromana, y determinadas hipótesis o interpretaciones podrían convertirse, si se procediera a su generalización, a distorsionar el hecho histórico basándose en informaciones arqueológicas parciales que necesitan un estudio integrador y contrastado.

La conquista romana de Segovia no aparece especificada en las fuentes clásicas, como en el caso de Cauca o Termes, y durante el conflicto sertoriano sólo sabemos de la recluta de jinetes y la derrota de Hirtuleyo en sus proximidades ${ }^{32}$. Posteriormente Segovia es mencionada entre las ciudades de los arévacos ${ }^{33}$. Se ha supuesto que este enclave fue un "campamento militar a lo largo de una importante parte de la dominación romana», desde mediados del siglo II a. C. y durante toda la República, en función de su situación geoestratégica ${ }^{34}$, mientras que otros autores sostienen que un campamento romano situado en el Álcázar «carece de todo fundamento arqueológico» ${ }^{35}$. Lo cierto es que hasta el momento no contamos en Segovia con materiales arqueológicos característicos de este tipo de enclaves, ya sean de época republicana o altoimperial ${ }^{36}$, y tampoco disponemos de datos que evidencien la participación de militares en la edificación del Acueducto, aunque es posible que algún licenciado se asentase en Segovia, como pudo ser el caso del tribuno Emilio Prisco Corneliano Lépido.

La información arqueológica sobre la Segovia republicana y sus primeros años imperiales es muy exigua, y no se ha publicado ningún material procedente de la ciudad de Segovia que se pueda asignar a las producciones de barniz negro o a la terra sigillata itálica. No obstante, siguiendo a J. F. Blanco ${ }^{37}$ : «estamos convencidos de que tarde o temprano comparecerá la TSI en Segovia capital». Por otro lado, se han dado a conocer un tetradracma de Antíoco Grypos (121-96 a. C.) y denarios de Sekobirikes y $\mathrm{Arsao}^{38}$, pero salvo las acuñaciones de ases con cabeza masculina

\footnotetext{
${ }^{32}$ LIV., Frag. 91; FLOR., 2, 10, 7.

${ }^{33}$ PLIN., Nat., 3.27; PTOL., 2.6.55.

${ }^{34}$ MARQUÉS MARTÍN, 2009: 208.

${ }^{35}$ MARTÍNEZ et al., 2015: 751.

${ }^{36} \mathrm{El}$ único conjunto de material romano del entorno segoviano fechable en época augustea y que puede ponerse en relación con la presencia de cuerpos militares son algunas producciones cerámicas - TSI, ánforas, vasos de paredes finas, morteros... - recogidas en la zona minera del Cerro de los Almadenes (DOMERGUE, 1979).

${ }^{37}$ BLANCO GARCÍA, 2003: 130.

${ }^{38}$ ABAD VARELA, 2002: 574.
} 
flanqueada por las letras C L y en el reverso jinete lancero con el rótulo «Segovia» en exergo $^{39}$, tampoco tenemos constancia de ninguna moneda augustea ni julioclaudia en las publicaciones sobre numismática segoviana ${ }^{40}$, si bien - como ya indica el propio Abad- la escasez de numerario publicado hasta ahora parece indicar que «faltan lotes por estudiar».

En función de los escasos datos que disponemos se ha considerado que Segovia adquirió la categoría municipal al recibir el derecho latino en época flavia ${ }^{41}$. La transcripción y reconstrucción interpretativa efectuada a partir de seis fragmentos de una tabula moldurada de bronce hallados en 1985 identifica al tribuno mencionado anteriormente como flamen del culto imperial de Tiberio, y ha llevado a defender que la obtención de este estatuto jurídico pudiera adelantarse a la época de este emperador ${ }^{42}$. No obstante, en función de los restos materiales publicados que conocemos hoy en día no es hasta mediados del siglo I d. C. cuando en esta ciudad parecen iniciarse los primeros indicios de la cultura urbana romana.

El Acueducto - y la investigación centrada sobre él- han mediatizado el estudio del urbanismo segoviano; incluso se ha dicho que «no sería absurdo que el Acueducto fuese la primera piedra del conjunto de una nueva ciudad $»^{43}$. No cabe duda de que su construcción condicionó las futuras edificaciones de la ciudad romana. El grueso de estudios han propuesto su construcción entre los emperadores Claudio y Trajano, siendo la lectura de su inscripción efectuada por G. Alföldy ${ }^{44}$ el análisis más ajustado, aludiendo a su restauración por parte de Trajano y proponiendo su obra originaria en época de Domiciano. En la actualidad, y en función de una excavación realizada en el año 1998 en sus pilares 115 y 117, se ha considerado la presencia de una moneda de Trajano y algunas cerámicas como referente para fechar su construcción a partir del año 117 d. C. ${ }^{45}$. Desde luego, no resulta apropiado datar la promoción de un edificio como el Acueducto de Segovia en función de una moneda, como ya hemos expuesto en otro lugar ${ }^{46}$. La realización de los grandes programas arquitectónicos del mundo

\footnotetext{
${ }^{39}$ MARQUÉS GONZÁLEZ, 2014: 73-90.

${ }^{40}$ Sobre este tipo numismático «anómalo» (que además implicaría la fundación augustea de la ciudad romana) se han planteado diversas dudas, y resulta singular que ninguna de las monedas conocidas proceda de excavación, documentándose en su totalidad en colecciones y circuitos anticuarios.

${ }^{41}$ MANGAS MANJARRÉS, 1996; ALFÖLDY, 1998.

${ }^{42}$ SANTOS YANGUAS et al., 2005: 144-148. La presencia del sacerdocio de tradición romana vinculado al culto imperial puede encontrarse en todo tipo de comunidades provinciales, independientemente de su condición jurídica, desde comienzos de época imperial hasta los siglos III-IV d. C. En provincias como la Tarraconense se estableció en las primeras décadas de la época imperial (14-37 d. C.), mientras que en la Bética —romanizada más tempranamentesu establecimiento es posterior (69-79 d. C.). Estos flamines eran elegidos por el concilium provincial, y sus funciones sacerdotales estaban ligadas al culto tanto de los emperadores vivos como divinizados. Una vez finalizados sus servicios recibían honores públicos - y en ocasiones una estatua- en señal de reconocimiento.

${ }^{43}$ ZAMORA CANELLADA, 1987: 45.

${ }^{44}$ ALFÖLDY, 1997.

${ }^{45}$ MARTÍNEZ et al., 2014: 1713-1715.

${ }^{46}$ PÉREZ GONZÁLEZ \& ARROYO RODRIGUEZ, 2011: 305.
} 


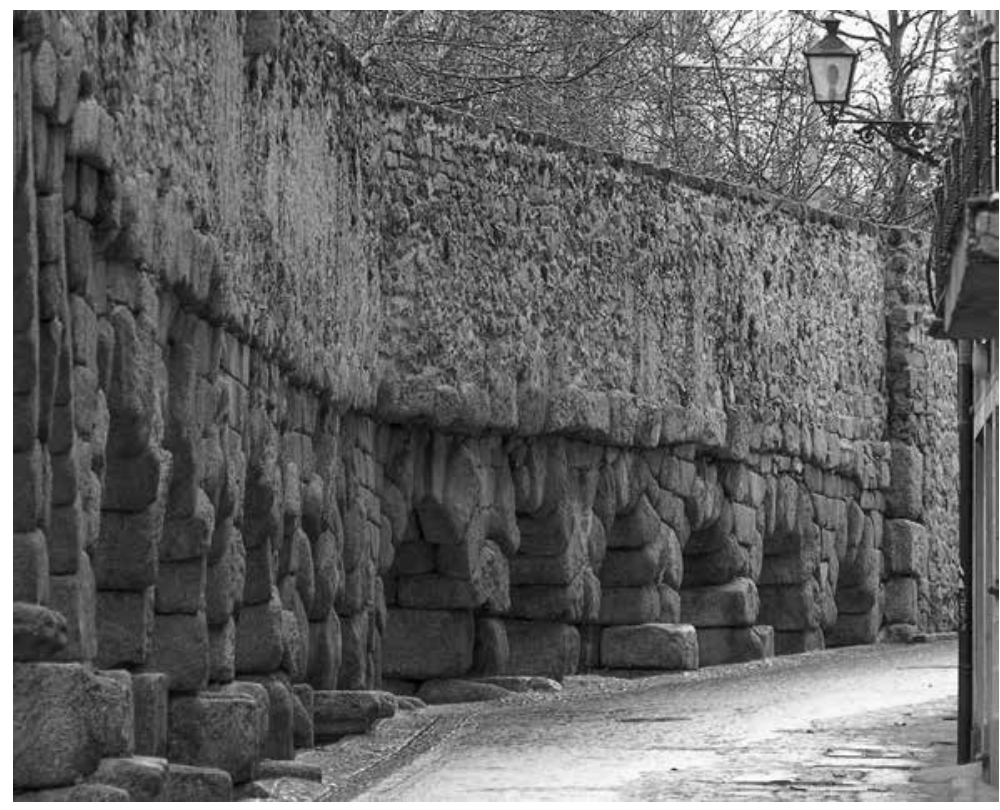

Fig. 4.

Acueducto de Segovia, primeros arcos.

romano no siempre se efectuó en periodos breves de tiempo, y la monumentalización de estos núcleos meseteños, condicionada por las limitaciones propias de la época y del lugar, así como por las posibilidades de los evergetas y sus familias, no debe de entenderse con la inmediatez que puede darse en la conformación ex novo de colonias como Augusta Emerita o Caesaraugusta.

A lo largo del siglo XIX se tiene constancia de noticias variadas sobre distintos restos arqueológicos, entre los que figura el hipocausto documentado en 1864 en el atrio de la iglesia de San Martín, identificado con unas termas - o habitación calefactada - que debían de estar en funcionamiento a partir de mediados del siglo I d. C. Esta misma cronología se apunta en el estudio, ajustado y meritorio, de las excavaciones efectuadas en la Iglesia de la Santísima Trinidad en los años 1986 y $1989^{47}$, donde se efectúa el registro de «la primera estratigrafía conocida de la ciudad», en la que figuran algunos fragmentos de terra sigillata gálica, entre los que se constata la marca del alfarero de La Graufesenque COSIVS-VRAPVS, también presente en Termes ${ }^{48}$. Las lucernas ${ }^{49}$ también permiten definir estas cronologías en la misma ubicación espacial.

\footnotetext{
${ }^{47}$ LÓPEZ AMBITE \& BARRIO ÁLVAREZ, 1995.

${ }^{48}$ PÉREZ GONZÁLEZ \& ARRIBAS LOBO, 2016: nota 10.

${ }^{49}$ Loesche IA ó III, Dressel 3...
} 
Como toda ciudad romana que se precie deberá contar con nuevos espacios y construcciones. Las excavaciones realizadas entre los años 1994 y 1996 en la Plaza de Guevara mostraron la disposición de grandes bloques de caliza asentados sobre la roca madre - característica que también observamos en Termes-, conservándose hasta dos metros de alzado con revestimientos murales pintados, molduras de yeso y variedad de material arqueológico (terra sigillata hispánica, vidrio ${ }^{50}$, etc.) datable entre época flavia y el siglo IV d. C. Su ubicación en una parte elevada de la ciudad y el hecho de constituir el primer conjunto notorio de restos romanos han llevado a distintos autores a situar en este lugar una parte del urbanismo público de la ciudad: el foro ${ }^{51}$, aunque la falta de un estudio detenido de su conjunto material nos lleva a considerar esta asignación con prudencia.

La calle Judería Vieja constituye otro punto de sumo interés para la arqueología romana en Segovia; las intervenciones de 1996 y 2007 en este lugar han aportado restos materiales fechados entre época flavia y el siglo III d. C., incluyendo elementos arquitectónicos - fustes y basas de columnas y pilastra, pintura mural, mosaico...- y fragmentos cerámicos variados - entre los que destaca un interesante fragmento de ánfora con tituli picti- hallados en la colmatación de una estructura negativa excavada en la roca ${ }^{52}$. Otras intervenciones nos permiten una aproximación a la urbanística de este período: Plaza de la Reina Doña Juana, Patio de los Osos del Palacio de Enrique IV, un sector junto a la calle Ildefonso Rodríguez, el solar de la Plaza Mayor que ocupó el antiguo Hotel Victoria y el Seminario Conciliar, este último con un conjunto cerámico en el que destacan un plato Drag. 18 de terra sigillata gálica marmorata ${ }^{53}$ y una forma 37 de terra sigillata hispánica, de entre mediados del siglo I d. C. e inicios del siglo II d. C.

Por lo que respecta al uso de espacios funerarios, los datos conocidos para la ciudad de Segovia se limitan a la necrópolis de incineración documentada en el atrio de la Iglesia de San Millán, para la que se ha se ha señalado que pudo mantener su uso hasta el siglo I d. C. - como también sucede en el caso de Carratiermes $-{ }^{54}$, y aunque se desconoce la ubicación del cementerio de época romana, son numerosos los epígrafes funerarios de este momento que han sido reaprovechados en el aparejo

\footnotetext{
${ }^{50} \mathrm{El}$ primer horizonte meseteño en el que hace presencia una difusión verdadera de vidrio romano data de finales de época julio-claudia y el comienzo de los flavios. Los recipientes soplados comienzan a aparecer en época de Tiberio, tratándose fundamentalmente de vasos y cuencos abiertos que generalizan su manufactura hacia mediados del siglo I d. C. No en vano Plinio (Nat., 36.194) nos transmite que su fabricación estaba muy difundida en Hispania en el tercer cuarto de este siglo.

${ }^{51}$ MARTÍNEZ et al., 2014: 1713.

${ }^{52}$ MARQUÉS MARTÍN \& HOCES DE LA GUARDIA BERMEJO, 2009; MARQUÉS MARTÍN \& BERMÚDEZ MEDEL, 2015-2016.

${ }^{53}$ Las producciones de terra sigillata gálica marmorata, presentes en los tres asentamientos, nos ayudan a definir aspectos significativos de utilidad y comercio entre los años 40-70 d. C. Este tipo cerámico se documenta en numerosos asentamientos hispanos, con soportes tanto lisos (Drag. 18, 35, 24/25 ó 27) como decorados (Drag. 29), si bien su presencia no es tan habitual como se supone, ni tan escasa como parece (PÉREZ GONZÁLEZ, 1984: 38-40).

${ }^{54}$ ZAMORA CANELLADA, 2000: 47.
} 
de su muralla medieval ${ }^{55}$, sumando un conjunto epigráfico significativamente mayor que el documentado en Cauca o Termes.

\section{TERMES}

Al igual que Cauca y Segovia, el emplazamiento de Termes se localiza sobre una posición destacada en altura, de marcado carácter defensivo. De los tres yacimientos es el único que no cuenta con la superposición de una ciudad actual, circunstancia que ha facilitado, en cierto modo, la realización de excavaciones sistemáticas ${ }^{56}$.

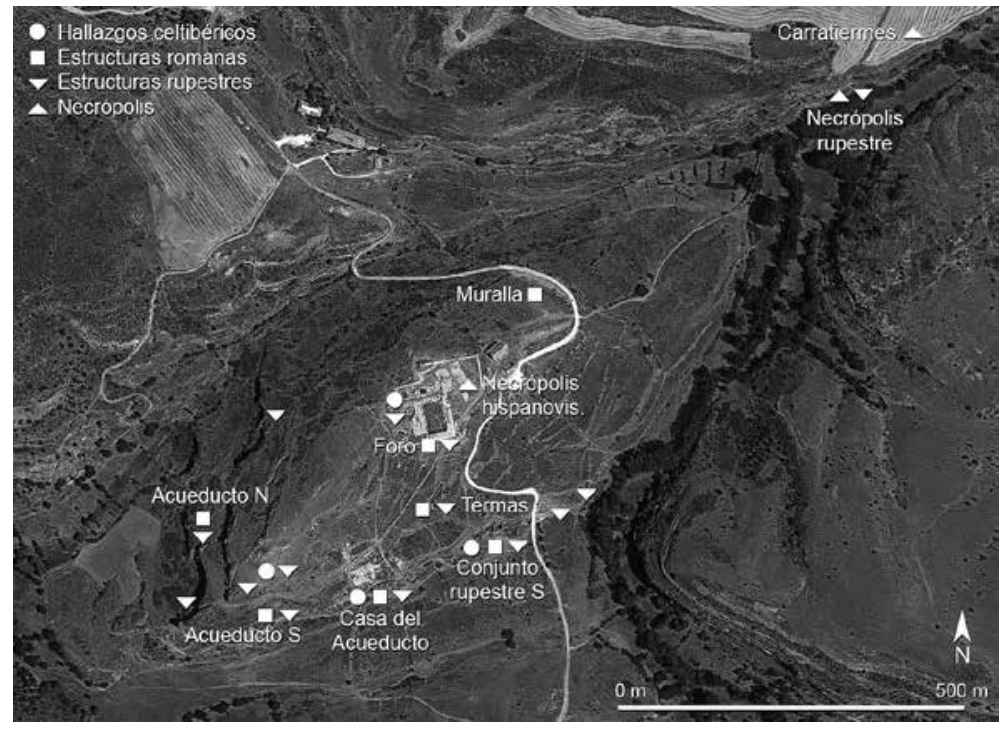

Fig. 5.

Principales conjuntos y vestigios arqueológicos en Tiermes.

PNOA, 2014.

Los restos materiales que han permitido identificar la ocupación humana más antigua en el entorno inmediato de Termes se corresponden con algunos hallazgos del Neolítico e inicios de la Edad de los Metales localizados en el terreno de Carratiermes, donde después se ubicaría la necrópolis celtibérica de incineración ${ }^{57}$. Este complejo funerario supone la evidencia más relevante que documenta el poblamiento de época prerromana, con un uso que se remonta a la segunda mitad del siglo VI a. C., asociándose al hábitat documentado en el "Cerro del Castro», localizado unos 900 metros en dirección suroeste y cuyos estratos de ocupación más antiguos, detectados en su terraza media, han sido fechados entre la segunda mitad del siglo $V$ a. C. y el siglo IV a. C. por la presencia de "cerámicas a mano, bruñidas e incisas» ${ }^{58}$.

\footnotetext{
${ }^{55}$ SANTOS YANGUAS et al., 2005.

${ }^{56}$ Una síntesis historiográfica en CASA MARTÍNEZ, 2013.

${ }^{57}$ ARGENTE et al., 2001.

${ }^{58}$ MARTÍNEZ CABALLERO \& MANGAS MANJARRÉS, 2005: 169-170.
} 
Las fuentes clásicas destacan el papel de Termes durante las guerras celtibéricas, y nos informan de su anexión al bando sertoriano y los consecuentes saqueos sufridos tras su derrota ${ }^{59}$. Tras estos episodios, el oppidum prerromano inicia su reconversión en núcleo romano ${ }^{60}$, si bien no resulta fácil desde el punto de vista arqueológico caracterizar sus horizontes tardorepublicanos o augusteos, aunque contamos con algunas monedas de este período ${ }^{61} \mathrm{y}$ el estudio de determinados tipos cerámicos - cerámica de barniz negro y algunas formas de la terra sigillata itálica- nos ha permitido reconocer este momento en tres zonas específicas del yacimiento: el lado oriental de la casa del acueducto, el Conjunto Rupestre del Sur y el área urbana del canal norte del Acueducto ${ }^{62}$. Respecto a la amonedación indígena, desconocemos la existencia de emisiones acuñadas por Termes; no obstante, la propuesta de Carlos Jordán $^{63}$ al respecto de la escritura celtibérica ha planteado una nueva lectura para la leyenda de las series monetales de Bormeskom ${ }^{64}$, aludiendo a la posibilidad de que la forma resultante -Tarmeskom- pudiese hacer referencia a una ceca celtibérica localizada en este oppidum.

Gran parte del núcleo urbano de Termes se encuentra aún sin excavar, razón por la que desconocemos aspectos fundamentales sobre el desarrollo y evolución de su urbanismo, y aunque en ocasiones se ha intentado hacer de los ejemplos de arquitectura rupestre termestina un elemento característico de su etapa indígena, la mayoría de los restos constructivos identificados en su solar con esta técnica edilicia se corresponden con momentos posteriores a la conquista romana. Esto se hace patente, sobre todo, en tres áreas del yacimiento: los dos ramales urbanos del acueducto, que horadan el cerro para abastecer de agua el centro de la ciudad; la casa del Acueducto, de inequívoca planta latina, y el Conjunto rupestre del Sur, cuyos acabados parietales también obedecen a tipología romana. A lo largo del siglo I d. C. la actividad edilicia y urbanizadora transformaría progresivamente el oppidum celtibérico en una ciudad romana que mantuvo, al menos hasta la primera mitad del siglo II d. C., una amplia actividad constructiva, también vinculada a la renovación de sus conjuntos monumentales ${ }^{65}$.

Una de las infraestructuras públicas de mayor relevancia que destaca y mediatiza el urbanismo de esta ciudad es el canal del acueducto, con dos ramales excavados en la roca que recorren el espacio urbano de su terraza media por sus lados norte y sur, y

\footnotetext{
${ }^{59}$ APP., Iber., 76-77, 99; SAL., Hist., 2.95.

${ }^{60}$ Durante la etapa altoimperial romana las menciones clásicas a esta ciudad se disipan tras un episodio del año $25 \mathrm{~d}$. C. (TAC., Ann., 4.45); en la segunda mitad del siglo I d. C. se referencia su integración dentro del Conventus Cluniensis (PLIN., Nat., 3.3.27) y en el siglo II d. C. es mencionada como una de las ciudades de los arévacos (PTOL., 2.6.55). 
del que se desconoce la mayor parte de su trazado extraurbano. Para su construcción no se dispone de ninguna fecha precisa, si bien hubo de ser, al menos en parte, anterior o coetánea al complejo foral ${ }^{66}$. En clara relación con el ramal sur de esta conducción hidráulica se encuentran los restos de un edificio explorado parcialmente a principios del siglo pasado e identificado como termas por diferentes autores ${ }^{67}$.

Por lo que respecta al principal espacio público de la ciudad romana, el foro, se ha visto sometido a diferentes propuestas interpretativas, referidas tanto a su ubicación y orientación como a la identificación de sus estructuras o su cronología ${ }^{68}$. Su caracterización, en base a las diferentes evidencias materiales que disponemos en la actualidad, nos permite ubicar este espacio en el sector central del núcleo urbano, consistente en una terraza porticada cuya construcción debió de comenzarse a mediados del siglo I d. C., quizás a partir del emperador Claudio o en momentos posteriores. El hallazgo de restos escultóricos fechados en el siglo II d. C. o la noticia de reformas ejecutadas en estos momentos en algunas de las edificaciones localizadas al norte de su pórtico septentrional nos muestran reflejos de una cierta actividad monumentalizadora en este complejo por lo menos hasta los momentos finales de esta centuria ${ }^{69}$.

Entre el extremo occidental de este espacio público y el canal norte del acueducto se localiza un área urbana de viviendas, estructurada en distintas manzanas separadas por calles y cuyos restos se encuadran en diferentes estadios cronológicos. Su distribución general corresponde al siglo I d. C., sobre un esquema precedente al que las diversas viviendas adaptan su planta, pudiendo observarse, además de las modificaciones urbanas provocadas por la construcción del acueducto y del propio foro, diversas adaptaciones y reformas entre los siglos II d. C. y época tardoantigua ${ }^{70}$.

Dentro de las construcciones urbanas de carácter privado, y aneja a la conducción hidráulica anteriormente comentada, ha sido excavada una importante residencia, conocida como la Casa del Acueducto. Se trata de una domus de unos $1800 \mathrm{~m}^{2}$ que dispone de un representativo programa de pintura mural que se conservaba in situ sobre el zócalo de algunas habitaciones y el peristilo de su impluvium, con un temática variada y correspondiente a diferentes estilos que permiten fechar la edificación de esta construcción a mediados del siglo I d. C. e identificar remodelaciones posteriores en época flavia y comienzos del siglo II d. C. ${ }^{71}$.

\footnotetext{
${ }^{66}$ ROMERO CARNICERO, 1992: 722.

67 TARACENA AGUIRRE, 1941: 113.

${ }^{68}$ Una síntesis historiográfica de esta problemática en PÉREZ GONZÁLEZ et al., 2014a: 831, fig. 1.

${ }^{69}$ PÉREZ GONZÁLEZ et al., 2011; DOHIJO, 2012-2013: 167-169.

${ }^{70}$ DOHIJO, 2012-2013: 148-159.

${ }^{71}$ ARGENTE OLIVER \& DÍAZ DÍAZ, 1994.
} 
Fig. 6.

Tiermes, conjunto rupestre del sur, con termas y foro en segundo plano.

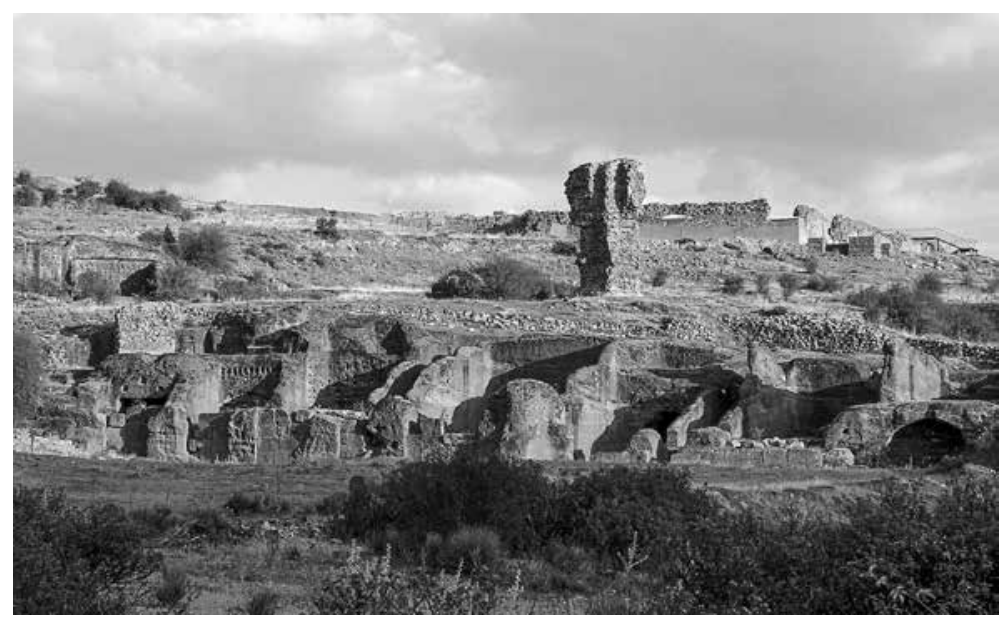

En el límite meridional del cerro se localiza una serie de habitáculos excavados en la roca que ejemplifican el particular empleo de la arquitectura rupestre que caracteriza este yacimiento. Restos de pintura mural que se han conservado adheridos a la roca en algunas de sus estancias poseen esquemas decorativos datables en la segunda mitad del siglo I d. C., aunque su edificación parece realizarse sobre construcciones anteriores. En estos edificios se desarrolla intensamente la vida hasta finales del siglo II o principios del III d. C., cuando la documentación de un horno en su espacio exterior, con síntomas indicativos de sucesivas reformas, muestra un cambio en el uso y ocupación de esta área previo al momento en que es amortizada con la construcción de la muralla ${ }^{72}$.

Sin duda, la construcción de la muralla de Termes implica una importante remodelación urbana, condicionando el hábitat termestino en la época bajoimperial. Su obra presenta dos partes claramente diferenciadas: una localizada al norte, con cubos semicirculares, y otra en el sureste, carente de éstos. Ambos tramos amortizan estructuras precedentes, asentándose el primero de ellos sobre diversas estancias del barrio norte, y en su tramo sureste sobre el conjunto rupestre del sur, revelando una reducción del espacio urbano, acotado a una superficie de 21 hectáreas. Los resultados de los trabajos de excavación desarrollados aquí desde finales de los años 70 del pasado siglo sugieren una fecha para su construcción a partir de la segunda mitad del siglo III d. C. ${ }^{73}$.

Los restos epigráficos termestinos no son muy abundantes, y su concentración coincide con los siglos I-II d. C., momento aparente del máximo esplendor de la

\footnotetext{
${ }^{72}$ ARGENTE OLIVER coord., 1996: 11-14.

${ }^{73}$ FERNÁNDEZ \& GONZÁLEZ, 1984: 209-211.
} 
ciudad $^{74}$. Ejemplos relevantes son una dedicatoria a Tiberio del 26 d. C., así como otra inscripción localizada en el área del foro en la que figura una cuantiosa dotación económica, probablemente de finales de época julio claudia, o un documento de hospitalidad localizado en las cercanías de Termes en el lugar conocido como «Las Cabezas» (Peralejo de los Escuderos) que documenta en el siglo II d. C. la condición municipal de Termes, con quattuorviri como magistrados.

Curiosamente, el conocimiento del que consideramos el momento de apogeo urbano de la ciudad romana no se ve acompañado por sus necrópolis, y de época altoimperial tan sólo se conocen de manera fragmentaria algunos epitafios descontextualizados ${ }^{75}$. No obstante, es preciso mencionar el mantenimiento del ritual de incineración en Carratiermes hasta el siglo I d. C. o comienzos del II d. C., como confirma la presencia de elementos cerámicos y numismáticos romanos entre sus ajuares ${ }^{76}$. Sumamente interesantes son las aportaciones de Marc Mayer y José A. Abásolo ${ }^{77}$ en lo referente a las estelas que se encuentran labradas en la roca junto a este lugar, que relacionan con la tipología de las lápidas romanas del Duero y que evidencian el carácter funerario de esta zona. También es relevante la reinterpretación como inscripción funeraria del epígrafe rupestre que se localiza en sus proximidades, dedicado a Basio Restituto y que fecharían en la segunda mitad del siglo II d. C.

A partir de época bajoimperial el registro funerario romano se documenta dentro del recinto amurallado, invadiendo espacios que en momentos anteriores se correspondían con la parte urbana del yacimiento, como el propio canal del acueducto, que ya se encontraría en desuso en el siglo IV d. C., cuando se fecha una de las dos sepulturas identificadas en 1982 sobre el trazado de esta obra hidráulica ${ }^{78}$. De igual manera sucede con el cementerio hispanovisigodo, localizado en el entorno del foro romano $^{79}$. Este autor propone también una datación de época tardoantigua -siglos V-VI d. C.- para la necrópolis rupestre situada en la margen izquierdo del río Manzanares, en base a los escasos materiales de ajuar recuperados y la proximidad del camino que conduce al yacimiento ${ }^{80}$, si bien nos gustaría contar con datos más concluyentes para establecer una cronología más precisa.

\section{CONCLUSIONES}

Tenemos desigual y deficiente grado de conocimiento de los tres enclaves referenciados, y los estudios, investigaciones y actuaciones arqueológicas han sido

\footnotetext{
${ }^{74}$ PÉREZ GONZÁLEZ et al., 2014c.

${ }^{75}$ PÉREZ GONZÁLEZ et al., 2014: nos 17, 26, 27...

${ }^{76}$ ARGENTE OLIVER et al., 2001: 193-194, 219-225.

${ }^{77}$ MAYER \& ABÁSOLO, 2001.

${ }^{78}$ ARGENTE OLIVER \& ALONSO CUBIAS, 1984: 417-431.

${ }^{79}$ DOHIJO, 2007.

${ }^{80}$ DOHIJO, 2014
} 
desiguales a lo largo del tiempo en cada uno de ellos. Se consolidan como núcleos poblacionales con anterioridad a la conquista romana, y su emplazamiento se mantiene tras ésta, aunque con diversas adaptaciones urbanísticas. Así, en su momento de contacto con el mundo romano, pueden considerarse como oppida indígenas, y parece que su transformación se produjo en los tres casos de manera lenta y progresiva. Así, a partir del cambio de Era y a lo largo de un proceso que se extendió durante varios siglos, fueron consolidándose lentamente como ciudades romanas del valle del Duero, cada una con sus características particulares, pero también con notorios aspectos comunes.

Indicativamente, la cultura material - especialmente cerámica - muestra mayor afinidad entre las producciones vacceas de Cauca y las registradas en Segovia que entre las dos ciudades arévacas; esto hace patente la existencia de relaciones estrechas, favorecidas por la proximidad geográfica y la fluidez de una ruta que facilitase la comunicación entre estos centros, atribuidos desde la óptica romana a grupos étnicos diferenciados, pero entre los que se identifica una gran permeabilidad, sobre todo en sus áreas fronterizas, también manifestada en la presencia de elementos como los verracos.

Conocemos muy poco del urbanismo indígena (e incluso del de época romana) y suponemos que sobre el sustrato indígena se establece el romano, pero es conveniente resaltar la dificultad de interpretación de una documentación escasa y puntual, debida mayoritariamente, en el caso de Cauca y Segovia, a intervenciones realizadas desde el ámbito de la arqueología de gestión, mientras que en Termes se ha aludido repetidamente al arrasamiento de sus horizontes prerromanos como consecuencia de la búsqueda de la roca como fundamento para las nuevas construcciones. Respecto a su extensión, conviene recordar que en líneas generales, las ciudades hispanas fueron de pequeño tamaño, y la meseta no se escapa a ello con ejemplos como Cauca, Segovia o Termes, cuya superficie de ocupación se estima entre las 20 y 30 hectáreas, si bien sería preciso acotar sus dimensiones en cada período significativo de su evolución urbana.

Las menciones clásicas son muy restringidas en los tres casos casos, siendo Cauca la mejor referenciada, seguida de Termes y por último de Segovia, que recoge un número menor de menciones, y pese a los episodios de conquista recogidos en las fuentes para el caso de las dos primeras, alusivos a los siglos II e inicios del I a. C., los horizontes más antiguos con vestigios romanos documentados en ambos se ajustan a los primeros años de nuestra era. Así, sabemos muy poco del período republicano en estos enclaves, y la fase augustea tampoco se manifiesta en ellos con un amplio elenco de restos materiales. Tal vez sea Termes, en función de sus hallazgos cerámicos y numismáticos, donde mejor se aprecia la presencia romana en este momento, del que conocemos muy poco en Cauca, mientras que la información es prácticamente nula en el caso de Segovia. 
La construcción de edificios públicos en época de Augusto fue muy escasa en esta zona de Hispania, y en función de lo que hoy conocemos no podemos asignar claramente en ninguno de los tres yacimientos restos constructivos de este período, por lo que es preciso recurrir al estudio de determinados tipos cerámicos que conviven en estos momentos - cerámicas de barniz negro, celtibérica tardía y pintada romana, así como terra sigillata itálica y en algún caso los primeros productos gálicos e hispánicospara definir las primeras relaciones comerciales y el proceso de romanización. También resulta singular para cada yacimiento el caso de las acuñaciones numismáticas: en Cauca se desconoce la producción de moneda propia; para Termes se ha propuesto la posibilidad de identificar con este núcleo las emisiones celtibéricas relacionadas con la ceca de Bormeskom, mientras que Segovia cuenta por su parte con la conocida serie de ases (siglo I a. C.), cuya problemática ya ha sido referida en otras ocasiones.

Para el estudio del desarrollo urbano de estas ciudades es preciso tener en cuenta el papel destacado que jugaron los grandes ejes viarios que comunicaban la Meseta norte con el valle del Ebro, así como el sistema de vías secundarias que permitín la conexión de los núcleos menores ${ }^{81}$. En el análisis específico de su urbanismo y arquitectura contamos con restos inconexos y aislados: se observa en los tres yacimientos un continuado proceso de construcción y remodelación de espacios (ya desde época indígena, y en varios momentos a partir de Tiberio-Claudio); y aunque los tres debieron de contar con muralla en época prerromana, sólo han sido publicadas recientemente las defensas de adobe de Cauca - documentadas tanto por las fuentes como arqueológicamente- y la de Segovia, construida en piedra - que no obstante es preciso reconocer mejor, si es que existió-, mientras que nada sabemos de la muralla arévaca de Termes, si bien esta ciudad es la única que conserva el trazado de su defensa bajoimperial.

La monumentalización urbana o la construcción de edificios públicos en estas ciudades se muestra de forma desigual a través de las excavaciones en Segovia y Termes, y en Cauca parece que se produjo en menor grado, con la excepción del complejo suburbano bajoimperial de las Pizarras. El foro de Termes es el único espacio público de estas características que se puede documentar en ellas; nada sabemos de este conjunto público en Cauca, y en Segovia, a falta de estudios monográficos, todavía constituye una suposición. Por otro lado, conocemos - al menos en partela existencia de infraestrucuras hidráulicas de entidad en Segovia y Termes; no así en Cauca, donde sólo pueden anotarse los restos de una posible cloaca.

Es conveniente recordar que los programas de monumentalización urbana suelen ser fomentados por la promoción jurídica de las ciudades, y este aspecto ha sido ampliamente discutido en estos tres yacimientos. Para el caso concreto de la provincia segoviana se desconocen sus fechas exactas, aunque se supone que algunos centros

${ }^{81}$ ABÁSOLO ÁLVAREZ, 1999: 28; ROMERO CARNICERO, 2010. 
debieron de conseguirlo en época julio-claudia y ya de manera generalizada durante los emperadores flavios -en concreto tras la promulgación por Vespasiano del Edicto de Latinidad en 73-74 d. C.-; no obstante, no hay consenso entre los investigadores, sobre todo en lo referente a si esta declaración afectó a todos los municipios o sólo a aquellos que reunían las condiciones óptimas para recibir este derecho. En el caso de Termes, Tiberio, Calígula o los flavios son propuestas recurrentes para la obtención de este estatuto jurídico. Es posible que estas ciudades experimentaran un desarrollo económico y social en función de su acercamiento o lejanía al valle del Ebro; por ello, no sería de extrañar que su acceso a la municipalidad romana haya sido escalonado con progresión de este a oeste, recibiendo este impulso Termes en primer lugar, después Segovia y muy similar en Cauca. No obstante, parece que el influjo romano no se manifiesta hasta época de Tiberio, y más claramente, en función del volumen de los restos materiales, con el reinado de Claudio. Como ha expuesto J. M. Abascal ${ }^{82}$ : «La datación de la progresión jurídica de las ciudades de Hispania sigue presentando muchos problemas cuando se desciende al plano individual de la historia de cada ciudad», y carecemos de información suficiente para valorar con exactitud hasta qué punto se cumplían las condiciones del acceso a la municipalidad en cada núcleo urbano, y aún menos para establecer con precisión la cronología de su promoción, debiendo de ser cautelosos con las épocas sugeridas por determinados indicios -arqueológicos, epigráficos, numismáticos, onomásticos...- no debiendo considerarse definitivas hasta que no se efectúen a cabo los estudios materiales pertinentes en los distintos asentamientos.

En cuanto a la arquitectura privada, disponemos de su mejor ejemplo — consistente en una gran domus (Casa del Acueducto) - en Termes, y quizás en Cauca el conjunto de los Cinco Caños pudiera formar parte de algún complejo de este tipo. Nada parecido podemos anotar en Segovia, con la salvedad de algunos restos documentados en posición secundaria, y también parece que la relación entre el núcleo urbano y sus áreas suburbanas es diferente en los tres casos: en Cauca se observan claramente ambas, mientras que en Segovia y Termes desconocemos estas últimas.

También es desigual el conocimiento que tenemos del registro funerario en sus diferentes etapas de poblamiento: Termes ofrece el ejemplo mejor conocido de necrópolis de incineración celtibérica, mientras que en Cauca y Segovia sólo conocemos este tipo de cementerios de manera muy parcial. Especialmente significativo resulta, sin embargo, el mantenimiento de su uso hasta momentos avanzados de la romanización, constatado en los casos de Termes y Segovia. Por otro lado, los tres yacimientos sólo han aportado elementos aislados que podemos vincular con sus cementerios

${ }^{82}$ ABASCAL PALAZÓN, 2006: 63. 
altoimperiales, y en el caso de Cauca y Termes — no así en Segovia-, conocemos bien sus camposantos tardoantiguos.

Por último, es sintomática la adopción de soluciones arquitectónicas de tipo rupestre que se documenta en numerosos ejemplos de Termes y Segovia, debido a la propia morfología del terreno sobre el que se asientan ambos núcleos urbanos, de roca arenisca en el caso del primero, y caliza en el segundo. Mientras tanto, la edilicia en Cauca se caracteriza por el mayoritario empleo del adobe — con la salvedad del conjunto monumental de Las Pizarras-, debido en parte a las características geológicas del lugar, más alejado de sus focos principales de aprovisionamiento de piedra. Sin embargo, es común en los tres asentamientos la reutilización sistemática de material constructivo procedente de edificios amortizados, como un patrón habitual que define el devenir de estos núcleos urbanos, hasta el abandono definitivo en el caso de Termes - que antes experimenta una patente reducción de su hábitat, evidenciada por el perímetro que delimita su muralla bajoimperial-, o su progresiva conversión en los núcleos urbanos contemporáneos que hoy se superponen a los horizontes del hábitat antiguo en los casos de Segovia y Coca.

\section{BIBLIOGRAFÍA}

ABAD VARELA, Manuel E. (2002) - La moneda y su circulación durante la Antigüedad en Segovia. In HERNÁNDEZ, Liborio; SAGREDO, Luis; SOLANA, José M. ${ }^{a}$, coord. - Actas del I Congreso Internacional de Historia Antigua «La Península Ibérica hace 2000 años». Valladolid: Universidad de Valladolid, p. 573-590.

ABASCAL PALAZÓN, Juan M. (2006) - Los tres viajes de Augusto a Hispania y su relación con la promoción jurídica de las ciudades. «Iberia», 9, p. 63-78.

ABÁSOLO ÁLVAREZ, José A. (1993) - La ciudad hispanorromana en la submeseta norte. In BENDALA, Manuel, coord. - La ciudad hispanorromana. Barcelona: Amhit, p. 191-205.

(1999) - Una perspectiva de ocupación del territorio a la llegada de los romanos. La Sub-meseta norte. In TAVARES, Lino; ARAÚJO, Jorge M. S. M. - Actas da Mesa Redonda Emêrgencia e desenvolvimento das cidades romanas no Norte da Península Ibérica. Porto: Escola Profissional de Arqueologia; Instituto Português do Património Arquitetónico, p. 17-36.

ALFÖLDY, Géza (1997) - Die Bauinschriften des Aquäduktes von Segovia und des Amphitheaters von Tarraco. «Madrider Forschungen», 19. Berlin-New York.

(1998) - Hispania bajo los Flavios y los Antoninos: consideraciones históricas sobre una época. In MAYER, Marc; NOLLA, Josep M.; PARDO, Jordi, coord. - De les estructures indigenes a l'organització provincial romana de la Hispania citerior. Homenatge a Josep Estrada i Garriga. Barcelona: Societat Catalana d'Estudis Clàssics, p. 11-32.

ALMAGRO-GORBEA, Martín; ABASCAL, Juan Manuel, (2008) - Termes y Segobriga y los orígenes del culto imperial en Hispania. In LA ROCCA, Eugenio; LEÓN, Pilar; PARISI, Claudio, coord. - Le due patrie acquisite. Studi di archeologia dedicati a Walter Trillmich. «Bullettino della Commissione Archeologica Comunale di Roma. Supplementi», 18. Roma, p. 15-25.

ARGENTE OLIVER, José Luis, coord. (1997) - Tiermes. Excavaciones arqueológicas. Campaña 1996. Soria. 
ARGENTE OLIVER, José Luis; ALONSO LUBIAS, Antonio (1984) - Dos enterramientos bajo imperiales en el acueducto de Tiermes. In CASA, Carlos de la, coord. - Actas del I Symposium de Arqueología Soriana. Soria: Diputación Provincial de Soria, p. 417431.

ARGENTE OLIVER, José Luis; DÍAZ DÍAZ, Adelia (1994) - Tiermes IV. La Casa del Acueducto (Domus alto-imperial de la ciudad de Tiermes. Campañas 1979-1986). «EAE», 167, Madrid.

ARGENTE OLIVER, José Luis; DÍAZ DÍAZ, Adelia; BESCÓS CORRAL, Alberto (2001) - Tiermes V. Carratiermes necrópolis celtibérica: campañas 1977 y 1986-1991. «Arqueología en Castilla y León. Memorias», 9. Valladolid.

BALIL ILLANA, Alberto (1986) - Arqueología de las ciudades modernas superpuestas a las antiguas. Zaragoza, 1983. «BSAA», 52, p. 542-543.

BALIL LLANA, Alberto; MARTÍN VALLS, Ricardo, coord. (1988) - Tessera Hospitalis de Montealegre de Campos (Valladolid): estudio y contexto arqueológico. «Monografías del Museo Arqueológico de Valladolid», 6.

BLANCO GARCÍA, Juan F. (1987) - Moneda y Circulación Monetaria en Coca (Siglos II a.C.-V d.C. Segovia: Caja de Ahorros y Monte de Piedad.

(1992) - El complejo alfarero vacceo de Coca (Segovia). «Revista de Arqueología», 130, p. 34-41.

(1995) - La investigación de la arqueología romana en la provincia de Segovia. "Anuario de la UISEK», 1, p. 37-52.

(2002), Coca. Cauca. In MAÑANES, T., coord. - Arqueología del Área Central de la Cuenca del Río Duero. De Simancas a Coca. Valladolid: Diputación Provincial de Valladolid, p. 127-173.

(2003) - Cerámica histórica en la provincia de Segovia, «TAH», 1.

(2010) - La ciudad de Cauca y su territorio. In MARTÍNEZ, Santiago; SANTIAGO, Jorge; ZAMORA, Alonso, coord. - Segovia romana II. Gentes y territorios. Segovia: Obra Social Caja Segoria, p. 221-249.

(2011) - Coca en los inicios de su historia. In VV. AA. - Historia de Coca. Estudios sobre Historia $y$ Arte en Coca. Segovia: Real Academia de Historia y Arte de San Quirce, p. 71-98.

(2011-2012) - Tres documentos iconográficos celtibéricos de la capital segoviana. «CuPAUAM», 37-38, p. 465-477.

(2014) - Piedra y barro. La muralla de la ciudad vaccea de Cauca. «Vaccea Anuario», 8, p. 38-46. (2016) - La vivienda vaccea. «Oppidum. Cuadernos de Investigación», 12, p. 43-84.

BLANCO GARCÍA, Juan F.; PÉREZ GONZÁLEZ, C. (2010-2011) - Una joya áurea del Bronce final Atlántico recuperada en la campaña de excavaciones arqueológicas de 1999 en Coca (Segovia). «Oppidum. Cuadernos de Investigación», 6-7, p. 7-36.

BLANCO GARCÍA, Juan F.; PÉREZ GONZÁLEZ C.; REYES HERNANDO O. V. (2012-2013) - Campaña de excavación arqueológica de 1999 en Cauca (Coca. Segovia). La secuencia estratigráfica. «Oppidum. Cuadernos de Investigación», 8-9, p. 29-144.

CABAÑERO MARTÍN, Víctor M. (2015) - La campiña segoviana en época romana (s. II a. C.-II d. C.). Segovia: Diputación de Segovia.

CASA MARTÍNEZ, Carlos de la (2013) - Cien años y varios días en el yacimiento de Tiermes. Aproximación historiográfica. «Revista de Soria», 80, p. 27-54.

DOHIJO, Eusebio (2007) - La necrópolis hispanovisigoda del área foral de Termes. «Pyrenae», 38-1, p. 129-162. (2012-2013) - Una visión retrospectiva de los trabajos efectuados en el yacimiento de Tiermes (Soria). Campañas 1998-2000. «Oppidum. Cuadernos de Investigación», 8-9, p. 145-178.

(2014) - De nuevo sobre la cronología de la necrópolis tardoantigua rupestre de Tiermes (Montejo de Tiermes, Soria). In HONRADO, José; BREZMES, Miguel Á.; TEJEIRO, A.; RODRÍGUEZ, Ó. - Actas de las Segundas Jornadas de Jóvenes Investigadores del valle del Duero. Valladolid: Glyphonos, p. 377-393. 
DOMERGUE, Claude (1979) - Le gisement de cuivre d'Otero de los Herreros (Segovia) et son exploitation à l'epoque romaine. «Revista de la Universidad Complutense», 118, p. 117-152.

FERNÁNDEZ MARTÍNEZ, Víctor; GONZÁLEZ UCEDA, Alfonso (1984) - La muralla romana. In ARGENTE OLIVER, José Luis, et al. - Tiermes II. Campañas de 1979 y 1980. Excavaciones realizadas en la Ciudad Romana y en la Necrópolis Medieval. «EAE», 123, p. 197-291.

GUTIÉRREZ DOHIJO, Eusebio; RODRÍGUEZ MORALES, F. Javier (1999) - Tiermes. Nacimiento, formación y desarrollo de una ciudad romana en la Celtiberia. In TAVARES, Lino; ARAÚJO, Jorge M. S. M. - Actas da Mesa Redonda Emêrgencia e desenvolvimento das cidades romanas no Norte da Península Ibérica (Porto, 1999). Porto: Escola Profissional de Arqueologia; Instituto Português de Património Arquitetónico, p. 171-190.

ILLARREGUI, Emilio (2016) - La ceca indígena de Bormes. «Oppidum. Cuadernos de Investigación», 12, p. 23-41.

JORDÁN CÓLERA, Carlos (2005) - ¿Sistema dual de escritura en celtibérico? In Actas del IX Coloquio Internacional sobre Lenguas y Culturas Paleohispánicas (Barcelona, 2004). «Paleohispánica», 5, p. 1013-1030.

LABRADOR, José Miguel; MARTÍN, Clara; MARTÍNEZ, Santiago (2016) - Nuevas aportaciones al conocimiento del sistema defensivo de la ciudad de Segovia en la II Edad del Hierro. Nuevos datos sobre la muralla celtibérica. In MARTÍNEZ, Santiago; CABAÑERO, Víctor M.; MERINO, Carlos, coord. - Arqueología en el Valle del Duero: del Paleolítico a la Edad Media. Valladolid: Glyphos, p. 127-140.

LÓPEZ AMBITE, Fernando; BARRIO ÁLVAREZ, Yolanda (1995) - Excavaciones arqueológicas de la iglesia de la Santisima Trinidad, Segovia. Valladolid: Junta de Castilla y Léon.

MANGAS MANJARRÉS, Julio (1996) - Aldea y ciudad en la antigüedad hispana. Madrid: Arco Libros.

MARQUÉS GONZÁLEZ, Néstor F. (2014) - La ceca latina de Segovia. Historiografía y planteamientos generales. «Oppidum. Cuadernos de Investigación», 10, p. 73-90.

MARQUÉS MARTÍN, Isabel (2009) - Segovia y su gestión arqueológica desde la perspectiva profesional. In AA.VV. - Arqueología, patrimonio histórico y urbanismo en las ciudades Patrimonio de la Humanidad en España, p. 203-215.

MARQUÉS MARTÍN, Isabel; BERMÚDEZ MEDEL, Alejandro (2015-2016) - Intervención arqueológica en la calle Judería Vieja, $n^{\circ}$ 19, de Segovia. «Segovia Histórica», 2-3, p. 35-54.

MARQUÉS MARTÍN, Isabel; HOCES DE LA GUARDIA BERMEJO, Ángel Luis (2009) - Un ánfora vinaria (Dressel 2-4) con inscripción en Segovia. «Veleia», 26, p. 363-371.

MARTÍN VELA, Raúl; MARCOS HERRÁN, Francisco Javier (2010-2011) - Cerámicas de la II edad del hierro en el foso de la calle Daoíz 13/Paseo Juan II (Segovia): interpretación y contextualización. «Oppidum. Cuadernos de Investigación», 6-7, p. 45-60.

MARTÍNEZ CABALLERO, Santiago (2010) - El foro romano de Termes (Hispania Citerior). Síntesis histórica, arqueológica y topográfica. S. I a. C. - s. II d. C. «AEspA», 83, p. 221-266.

MARTÍNEZ, Santiago; CABAÑERO, Víctor M.; ÁLVAREZ, Sonia; GALLEGO, José Ignacio; MUNICIO, Luciano (2014) - La ciudad celtíbera y romana de Segovia (Hispania Citerior) desde la investigación arqueológica. Nuevas perspectivas. In ÁLVAREZ, José M.a; NOGALES, Trinidad; RODÀ, Isabel, coord. - XVIII Congreso Internacional de Arqueología Clásica. Mérida, vol. II, p. 1711-1715.

MARTÍNEZ, Santiago; CABAÑERO, Víctor M.; MARTÍN, Clara; LABRADOR, José M.; ÁLVAREZ, Sonia (2015) - Segovia, ciudad romana. In MARTÍNEZ, Santiago; VILCHES, Susana, coord. Imago Urbis Romae, Ciudades Romanas de Segovia. Segovia: Diputación de Segoria; [Valladolid]: Junta de Castilla y León, p. 75-91.

MARTÍNEZ CABALLERO, Santiago; MANGAS MANJARRÉS, Julio (2005) - Tiermes celtibérica. In JIMENO, Alfredo, coord. - Tras la estela de Numancia. Catálogo de la exposición. Soria, p. 169-175. 
MAYER, M; ABÁSOLO, J. A. (2001) - Estelas rupestres en Hispania, la necrópolis de Termes. In Vaz, J. L. Inês, coord. - Saxa Scripta. Actas do III Simposio Ibero-Itálico de epigrafía rupestre. Viseu, p. 161-179.

MOREDA, Francisco J.; REYES, Olivia V.; SERRANO, Rosalía; MOREDA, Lara M. ${ }^{a}$ (2010-2011) - El seguimiento arqueológico realizado en el solar situado entre el $n^{\circ} 13$ de la calle Daoíz y el paseo de Juan II (Segovia). «Oppidum. Cuadernos de Investigación», 6-7, p. 37-44.

MUNICIO GONZÁLEZ, Luciano (2000) - Datos arqueológicos sobre la Segovia Romana. In VV. AA. - Segovia Romana. Segovia, p. 73-86.

PÉREZ GONZÁLEZ, Cesáreo (1984) - Calvo: alfarero gálico, inédito hasta ahora, en la cuenca del Duero y zona cantábrica. «PITTM», 51, p. 33-45.

PÉREZ GONZÁLEZ, Cesáreo; ARRIBAS LOBO, Pablo (2016) - Cerámicas con grafito y algunos sigilla en TSH de Termes. «Oppidum. Cuadernos de Investigación», 12, p. 85-147.

PÉREZ GONZÁLEZ, Cesáreo; ARROYO RODRÍGUEZ, Luis A. (2011) - El Acueducto de Segovia. Viajes, viajeros y algo de Arqueología. Segovia.

PÉREZ GONZÁLEZ, Cesáreo; BLANCO GARCÍA, Juan F. (2000) - Nuevas investigaciones arqueológicas en Cauca. «Revista de Arqueología», 228, p. 38-47.

PÉREZ GONZÁLEZ, Cesáreo; ILLARREGUI GÓMEZ, Emilio; ARRIBAS LOBO, Pablo (2010-2011) Moneda y Foro en Tiermes (Soria, España). «Oppidum. Cuadernos de Investigación», 6-7, pp. 61-84. (2011) - Nuevos hallazgos de estatuaria en Tiermes. In NOGALES, Trinidad; RODÀ, Isabel, coord. - Roma y las provincias: modelo y difusión. Roma: L'Ema di Bretschneider, vol. II, p. 787-796. (2014a) - Evidencias materiales para la caracterización del foro altoimperial de Tiermes. In ÁLVAREZ, José M.a; NOGALES, Trinidad; RODÀ, Isabel, coord. - XVIII Congreso Internacional de Arqueología Clásica. Centro y periferia en el Mundo Clásico. Mérida, 13-17 mayo, 2013. Mérida: Museo Nacional de Arte Romano, vol. I, p. 831-835.

(2014b) - Tiermes Laboratorio Cultural. Novedades arqueológicas de las intervenciones del 2007 al 2011. In BURILLO, Francisco; CHORDÁ, Marta, coord. - VII Simposio sobre los celtíberos. Nuevos hallazgos, nuevas interpretaciones. «Estudios Celtibéricos», 7. Zaragoza, p. 523-539.

(2014c) - Tiermes 2013. Intervención arqueológica y parerga epigráfica. «Oppidum. Cuadernos de Investigación», 5, p. 107-146.

(2015a) - La arqueología augustea en algunas ciudades del Duero, In LÓPEZ VILAR, Jordi, coord. - Actes. 2on Congrés Internacional d'Arqueologia i Món Antic. August i les províncies occidentals. 2000 aniversari de la mort d'August. Tarragona: Fundació Privada Mútua Catalana, vol. 2, p. 57-65. (2015b) - Tiermes en los siglos II-IV. Evolución del poblamiento y del urbanismo de una ciudad de la cuenca del Duero. In BRASSOUS, Laurent; QUEVEDO, Alejandro, coord. - Urbanisme civique en temps de crise. Les espaces publics d'Hispanie et de l'Occident romain entre le IIe et le IVe siècle. «Collection de la Casa de Velázquez», 149. Madrid, p. 237-251.

PÉREZ GONZÁLEZ, Cesáreo, C.; REYES HERNANDO Olivia V. (2007) - Coca, la antigua Cauca. In NAVARRO Milagros; PALAO, Juan José, coord. - Villes et Territoires dans le Bassin du Douro á l'Époque Romaine. Bordeaux: Ausonius, p. 148-170.

, coord. (2012) - Proyecto de investigación Cauca. Las Pizarras 2006-2009. Coca (Segovia). «Anejos de Oppidum», 2. vols. I-IV. Segovia.

(2014) - La residenza di Coca (Segovia). In PENSABENE, Patricio; SFAMENI, Carla, coord. - La villa restaurata e i nuovi studi sulledilizia residenziale tardoantica. "Colana di ricerche storiche $\mathrm{e}$ archeologiche», 23. Bari, p. 487-498.

(2017) - Life and Death in Las Pizarras: functional transformations in Late Antiquity. In TEIXEIRA, Cláudia; CARNEIRO, André, coords. - Arqueologia da transição: entre o mundo romano e a Idade Média. Coimbra: Imprensa da Universidade de Coimbra, p. 387-414. 
PÉREZ GONZÁLEZ, Cesáreo; REYES HERNANDO, Olivia V.; BRAGADO ÁLVAREZ, M. ${ }^{a}$ Dolores; ARAUJO ARMERO, Rafael; ANDRÉS COBETA, F. Javier (2016) - Arquitectura romana tardoantigua: revestimiento de nácar en uillae hispanas del siglo IV d. C. «Oppidum. Cuadernos de Investigación», 5, p. 113-140.

PÉREZ GONZÁLEZ, Cesáreo; REYES HERNANDO, Olivia V.; RODÁ, Isabel; ÁLVAREZ, Aurelio; GUTIÉRREZ, Anna; DOMĖNECH, Ana; ROYO, Hernando (2012) - Use of marmora in the ornamental program of Las Pizarras roman site (ancient Cauca, Segovia, Spain). In GUTIÉRREZ, Anna; LAPUENTE, Pilar; RODÁ, Isabel, coord. - Interdisciplinary Studies on Ancient Stone. Proceedings of the IX ASMOSIA Conference. «Documenta», 23. Tarragona, p. 151-160.

REYES HERNANDO, Olivia V. (2017) - Prospección geofísica en la tierra de Las Pizarras (Coca, Segovia): primeros resultados. «Oppidum. Cuadernos de investigación», 13, p. 131-144.

REYES HERNANDO, Olivia V.; PÉREZ GONZÁLEZ, Cesáreo (2011) - Cauca: Arquitectura Monumental Tardoantigua. In NOGALES, Trinidad; RODĀ, Isabel, coord. - Roma y las Provincias: modelos y difusión. XI Coloquio Internacional de Arte Romano Provincial (Mérida, 18-21 de mayo de 2009). Roma, vol. II, p. 797-805.

ROMERO CARNICERO, M. ${ }^{a}$ Victoria (1992) - La romanización de la provincia de Soria: Panoramas y perspectivas. In CASA, Carlos de la, coord. - II Symposium de Arqueología Soriana. Homenaje a Teógenes Ortego y Frías, 19-21 de octubre de 1989. Soria: Diputación Provincial, vol. II, p. 699-735. (2010) - El proceso de urbanización romano y su relación con el trazado viario. In - Actas Coloquio Internacional «Patrimonio Cultural y Territorio en el valle del Duero», [Valladolid] : Consejería de Cultura y Turismo, p. 289-307.

SANTIAGO, Jorge; MARTÍNEZ, Santiago (2010) - La ciudad de Segovia y su territorio. In MARTÍNEZ, Santiago; SANTIAGO, Jorge; ZAMORA, Alonso, coord. - Segovia romana II. Gentes y territorios. Segovia: Caja Segovia, p. 149-155.

SANTOS YANGUAS, Juan; HOCES DE LA GUARDIA, Ángel Luis; HOYO, Javier del (2005) - Epigrafía romana de Segovia y su provincia. Segovia: Caja Segovia.

TARACENA AGUIRRE, Blas (1941) - Carta Arqueológica de España. Soria, Madrid.

ZAMORA CANELLADA, Alonso (1987) - Historia de Segovia. Segovia: Caja de Ahorros y Monte de Piedad de Segovia.

(2000) - Roma, desde el Museo de Segovia. In VV. AA. - Segovia romana. Segovia, p. 45-70. 



\title{
ANO ZERO, ANO 100, NO TERRITORIUM DE TONGOBRIGA
}

\author{
LINO TAVARES DIAS*
}

Ao procurar seguir o desafio proposto pelo Encontro Construir, Navegar, (Re)Usar o Douro da Antiguidade, propus-me apresentar uma síntese dos resultados das escavações arqueológicas que coordenei durante mais de três décadas em Tongobriga. O título que propus procurava salientar os momentos que cronologicamente se demarcam na construção do sítio, afirmando o «castro romano» na charneira do século I a. C. para o século I e o planeamento urbano que afirma a cidade nos finais do século I e no século II.

Mas, num texto inserido no livro de Jorge Alves, publicado em 2017 sobre o Poder Local em Marco de Canaveses, procurei, também, refletir sobre o futuro de Tongobriga e, então, intitulei-o «escavar o futuro». Decidi retomar, agora, esta reflexão, para além de tentar responder ao desafio inicial que tinha proposto para abordar no Encontro de outubro de 2017. Mas, tal como então, este título parece contraditório. Como escavar o futuro de uma cidade romana?

«Tempo que há-de vir» ou «daqui em diante», são expressões de «futuro», segundo o Grande Dicionário de José Pedro Machado, 1981.

Em contrapartida, escavar, fazer escavação arqueológica, é trabalho que o arqueólogo realiza, com metodologia científica, para conhecer e reconstituir o passado. Escavar é sinónimo de pesquisar, investigar, procurar, explorar, segundo o mesmo dicionário.

\footnotetext{
* CITCEM e CEAU, arqueólogo. ldias@ispgaya.pt.
} 
Ao arqueólogo compete, prioritariamente, reconhecer as marcas deixadas pelo homem mas, também, é-lhe exigido que as assuma como contributos e ensinamentos primordiais para o pensamento prospetivo.

Pode argumentar-se que o "futuro» não é objetivo primordial do trabalho do arqueólogo mas, em contrapartida, e em simultâneo, é fundamental o seu contributo para o planeamento do território. Mais evidente se torna a responsabilidade quando um arqueólogo é incumbido de desenvolver gestão integrada de sítios assumidos como património cultural. Tive o privilégio de assumir estas responsabilidades ao longo de anos e, por esta razão, neste texto assumo as duas vertentes, a de arqueólogo e a de gestor de património. A primeira privilegia a investigação, o passado; a segunda defende a prospetiva, o futuro.

Começo pela abordagem do arqueólogo. Compete-lhe reconhecer as ações que o homem fez a partir dos vestígios que o tempo proporcionou, perceber os contextos em que tal aconteceu e, se possível, saber quando aconteceu.

Para tal, é indispensável a escavação arqueológica e, nela, a observação da estratigrafia dos solos, dos depósitos de «restos», objetos perdidos, ocasionais, até lixos de obra e entulhos. Sem estratigrafias é difícil, quase impossível, analisar e contextualizar um sítio arqueológico.

As estratigrafias arqueológicas e, principalmente, os resultados que elas proporcionam, são os fatores mais impressionantes com que um arqueólogo trabalha e, em muitas ocasiões, se surpreende, independentemente da monumentalidade das ruínas exumadas.

O estudo das estratigrafias é complexo, assumidamente sujeito a reinterpretações, exigente, de grande rigor científico e com obrigações de verdade.

Concentremo-nos nos resultados proporcionados pela escavação arqueológica nos terrenos da aldeia do Freixo, em Marco de Canaveses, onde iniciei escavações arqueológicas em 1980. Depois, foi a gradual identificação das ruínas da cidade de Tongobriga, onde as estratigrafias observadas perspetivaram que foi quase toda construída quando a cultura romana ali predominou, entre finais do século I a. C. e o século II d. C., apesar de perdurar ao longo dos séculos seguintes.

No final do século I a. C., e no início do século I d. C., foi construído um castro ex nihilo, com muralha de troços retilíneos. Junto dela, no lado exterior, a sul, foi construído o balneário do tipo pedra formosa. $\mathrm{Na}$ área interior da muralha, com cerca de 13 hectares $\left(138.000 \mathrm{~m}^{2}\right)$, foram identificadas casas de planta circular, de arquitetura tradicional, construídas em granito e cobertura em colmo.

No final do séc. I d. C. foi feita a implantação do Actus Quadractus, assumida como estruturação da cidade que vai sentir-se no início do século II. A muralha foi ampliada, de modo a integrar os novos espaços públicos monumentais, embora salvaguardando a continuidade da necrópole de cremação, já existente, e que, assim, se 
manteve no exterior do novo traçado. A área global de espaço intramuralha passou para cerca de 21 hectares $\left(21.650 \mathrm{~m}^{2}\right)$.

As estratigrafias comprovaram, por exemplo, que o edifício das termas foi construído nas últimas décadas do século I. Harmonizado com a implantação e o projeto deste edifício característico da cultura urbana romana, já no início do século II foi construído um forum, reconhecido como espaço central onde os manuais do urbanismo "vitruviano» integravam o templo, a praça e a basílica, traduzindo a religião, o comércio e a administração da civitas, entendida como capital de um territorium assumido como unidade político-administrativa basilar na organização do Império e que no noroeste correspondia à área de cinco ou seis concelhos médios atuais.

Estas construções, que afirmaram Tongobriga como cidade, foram edificadas em espaços amplos, embora adjacentes ao povoado que já existia e que, segundo as estratigrafias observadas, tinha sido construído cerca de 100 anos antes, em meados e finais do século I antes de Cristo. O povoado que antecedeu a cidade foi construído com as técnicas da arquitetura castreja, conhecidas por serem casas de planta circular e com cobertura em colmo.

A estratigrafia mostrou que estávamos perante um «castro» construído em período da governação de Augusto, certamente fruto da política de motivação à mobilidade das populações, o que poderá ser entendido na afirmação do geógrafo Estrabão, segundo o qual «os romanos os pacificaram com uma política de transferência de populações, fazendo-as abandonar a habitação na montanha» ${ }^{1}$.

Sabemos que muitas destas casas «castrejas» foram demolidas no início do século II, por necessidade de promover a remodelação da urbe, a qual obrigou à criação de espaços capazes de acolher as domus, casas romanas de características urbanas. Nos entulhos dos alicerces das casas «castrejas», total ou parcialmente demolidas, predominavam os fragmentos cerâmicos romanos, mostrando que os construtores já usavam no quotidiano os utensílios com novas pastas, argilas, formas e fabricos que a nova economia foi introduzindo em todo o Império. De facto, foram poucas as cerâmicas castrejas recolhidas nestas estratigrafias. Isto foi fruto, certamente, da influência de quem mandara fazer o «novo castro» em terrenos em torno dos 300 metros de altitude, mais adequado às exigências romanas, preterindo os terrenos em torno dos 400 metros de altitude, onde predominavam os «castros antigos» existentes na região, tais como Arados, Quires e Soalhão, entre outros. A escavação arqueológica permitiu estudar estratigrafias que revelam que a população que construiu Tongobriga já usava a moeda romana, embora, em contrapartida, continuassem a usar algumas cerâmicas de fabrico local e regional, predominantemente as de maiores dimensões, talhas e dolia, destinadas, predominantemente, a armazenamento de cereais, vinho

${ }^{1}$ VELOZO \& CARDOSO $e d ., 1965$. 
ou azeite. Eram cerâmicas vulgares na cultura castreja do noroeste e que continuaram a ser usadas com os romanos, certamente porque continuaram a ser adequadas às necessidades de armazenamento, para além de serem de difícil transporte.

Constatamos que em Tongobriga, no final do século I a. C. e no início do século I d. C., foi construída uma muralha com troços retilíneos. Junto dela, no lado exterior, a sul, foi construído o balneário do tipo pedra formosa, confirmando o que Estrabão escreveu: «Dos que habitam junto do rio Douro, alguns vivem à maneira dos Lacedemónios, untam-se duas vezes ao dia e tomam banhos de vapor que fazem com pedras ao rubro» ${ }^{2}$.

A área do «castro» onde identificamos as casas de planta circular, cercada por muralha, tinha cerca de 13 hectares $\left(138.000 \mathrm{~m}^{2}\right)$.

As casas de planta circular e com cobertura em colmo, características da arquitetura castreja, foram identificadas durante as escavações arqueológicas, as quais também permitiram afirmar que essas casas foram totalmente substituídas, em cerca de duas gerações, por casas de arquitetura romana do tipo itálico, totalmente cobertas por telha cerâmica.

Algumas destas novas casas já permitiam a circulação sequencial entre salas, enquanto outras eram casas com corredor a ligar as salas e, ainda, outras estruturavam-se em torno de um pátio central com impluvium.

Em Tongobriga também se reconhece que foi a partir de finais do século I e, ainda, durante a primeira metade do século II, que foram construídos o forum, as termas e o eventual teatro, todos implantados em espaços situados no sul da cidade, assumidamente no exterior da primeira muralha. A construção destes edifícios públicos, marcantes da cidade, obrigou a ampliar o espaço da urbe, de modo a salientá-los no novo urbanismo. Apesar da ampliação do espaço público para fruição da cidade, o projeto da nova urbe teve o cuidado de salvaguardar a necrópole de cremação já existente e que, por isso, se manteve no exterior do traçado da nova muralha. A área global de espaço intramuralha passou de cerca de 13 para cerca de 21 hectares $\left(21.650 \mathrm{~m}^{2}\right)$.

A construção do conjunto de espaços e edifícios públicos que transformaram Tongobriga numa urbe, apesar de poder ter resultado da política transduriana desenvolvida desde Augusto, foi concentrada em período flaviano, já depois da governação do imperador Vespasiano entre os anos 69 e 79. Na estruturação e construção desta cidade, no final do século I e no início do século II, o actus foi o suporte à malha quadricular que ordenou todos os projetos, apesar da difícil implantação num terreno granítico e morfologicamente acidentado.

No entanto, o que mais surpreende é o rigor da implantação urbanística, sempre baseada no actus quadratus, e a qualidade dos projetos dos edifícios onde o passus foi usado como modelo do desenho. O uso cuidadoso destas medidas, e proporções, transmitiu ao sítio uma qualidade urbana evidenciada no forum, nas termas, no teatro e nas domus.

${ }^{2}$ VELOZO \& CARDOSO ed.: 1965. 
A análise da evolução do urbanismo de Tongobriga permitiu-nos não só confirmar que foi suportado na reprodução, nos sentidos norte/sul e este/oeste, do actus quadratus mas, também, confirmou a cuidadosa adaptação em vários espaços da cidade onde implantaram as construções rigorosamente segundo diagonais a $45^{\circ}$, harmonizando com a morfologia granítica dos terrenos. Este tipo de implantação também foi reconhecido durante as escavações arqueológicas que se concentraram no que se julga ser o teatro ou anfiteatro e que seria servido por uma rua, também ela traçada segundo uma diagonal a $45^{\circ}$, assumindo-se como um eixo que cortava transversalmente a área poente da cidade, desde cota mais alta até ao teatro, situado numa cota mais baixa.

Os novos sistemas de intervenção introduzidos pelos romanos nos territórios de todo o Império, realçando a novidade que representava a cidade e a civitas, tiveram repercussões profundas nas economias locais e no quotidiano das populações.

As alterações profundas no modo de viver foram motivadas não só pelos novos processos de organização do trabalho durante a construção da cidade, reconhecidos em Tongobriga pelas exigências impostas pelas grandes empreitadas dos edifícios públicos mas, também, motivados pela quantidade de mão-de-obra que passou a ser exigida para cultivar as terras envolventes da cidade e capazes de produzir alimentos suficientes para a subsistência das populações que ajudaram a construir a cidade em apenas algumas décadas.

Os novos sistemas de organização, política e social, desenvolvidos no século I terão, certamente, alterado as relações «tribais» de algumas populações, não só pelo reagrupamento social nas novas estruturas em construção mas, também, pelas alterações das relações administrativas, políticas e culturais motivadas pelas empreitadas para construção da cidade e, depois, pela especificidade da vida na urbe, com o surgimento de novas profissões, novos consumos e outros costumes.

Perante o estado atual do conhecimento, pode dizer-se que Tongobriga foi a cidade mais ocidental na bacia do Douro, com edifícios públicos construídos no fim do século I e início do século II, integrando um conjunto que se desenvolveu, no plano urbano e arquitetónico, durante a dinastia flaviana, o que pode ser entendida como materialização do desejo político, estratégico, expresso num «decreto» ditado pelo Imperador Augusto, em fevereiro de 15 a. C., durante a sua presença em Narbona. Nesse decreto mostrou vontade e decisão política para fazer ensaios de organização e de vertebração do território a Norte do rio Douro, para além de induzir e promover a ocupação territorial do que poderia constituir uma província Transduriana, hipótese política e estratégica romana, que não se concretizou formalmente, mas que tinha como eixo fundamental a bacia do rio Douro, atingindo a fronteira natural que o Oceano Atlântico representava, então, para o mundo.

Para a construção de Tongobriga, tal como aconteceu noutras cidades construídas na bacia do rio Douro, exemplificadas por Clunia, Uxama, Tiermes, Segontia 
Lanca, Petavonium e Aquae Flaviae, foram aplicadas todas as regras da topografia e foram usadas as melhores técnicas de implantação dos edifícios, quer fossem públicos quer fossem privados. A mesma qualidade constatou-se nas técnicas construtivas que foram aplicadas para executar projetos de arquitetura e de engenharia de grande precisão, comprovando que a vontade de desenvolvimento da civilização se manifestava, também, através da intensa atividade de edificação pública e privada. Manuela Martins e Jorge Ribeiro ${ }^{3}$ salienta que também Bracara Augusta, assumida como capital do Conventus Bracaraugustanos em que se integrava Tongobriga, foi edificada com os mesmos critérios de rigor e de acordo com as mesmas medidas, fosse o actus quadratus, fosse o passus.

Há, também, que salientar as lógicas administrativas aplicadas na infraestruturação do territorium, desde a cidade aos povoados secundários, aos vici, às estradas e aos seus traçados, desde as travessias dos rios até aos pontos de acostagem.

Foram os romanos que introduziram na paisagem deste território a "estrada», noção nova que substituiu o «caminho», o qual apenas permitia ligar pequenas distâncias, a pé ou a cavalo, usando os montes e vales que facilitavam o percurso mais curto. A estrada romana, pelo contrário, procurava ligar locais longínquos, sem deixar de servir, igualmente, os que mediavam ao longo dela. Mas, para além destas estradas terem sido construídas com o intuito de permitir a ligação entre cidades, eram traçadas e construídas de modo a que facilitassem a circulação de carros carregados com produtos, com tração de um ou mais animais, procurando conciliar as subidas e as descidas com troços sem grandes inclinações, permitindo, assim, evitar esforços exagerados e melhorar a capacidade de circulação dos produtos e das pessoas. As estradas romanas foram uma prova de planeamento que procurava maior rentabilidade, demonstrando um uso inteligente do território ${ }^{4}$. Por exemplo, neste território predominantemente montanhoso, as mansio e mutatio, enquanto áreas de serviço para troca, descanso e alimentação de animais e de viajantes que usavam as «novas» estradas, estruturaram-se em torno de distâncias de 12, 18 e 24 milhas, apoiando os percursos a partir de Tongobriga até Meinedo (12 milhas), até Várzea do Douro (12 milhas), até Lomba e Aboadela (12+12milhas), até Porto Manso (12 milhas) e até Santa Marinha do Zêzere (18 milhas).

No caso de Tongobriga, assumida como capita viarium e como capital de civitas, o seu território administrativo estendia-se até ao rio Douro, até ao Marão, até terras que atualmente são de Penafiel, Lousada, Paredes e Amarante, para além de Marco e Baião.

A malha ortogonal implantada em Tongobriga no final do século I continuou a servir de referência às construções, e remodelações, feitas ao longo dos séculos II,

\footnotetext{
${ }^{3}$ MARTINS \& RIBEIRO, 2018.

${ }^{4}$ COSTA et al., 2014.
} 
III e IV. No entanto, já no século VI a basílica paleocristã foi implantada num espaço central das áreas habitacionais, sinal evidente de que o forum já não era o espaço central para a nova religião que contrariava o politeísmo oficial romano.

Entretanto, ao longo dos séculos, os homens medievais, modernos, e até os dos nossos dias, retiraram e serviram-se de muita pedra das ruínas de Tongobriga.

No final do século XX iniciámos as escavações arqueológicas. Com esse trabalho sistemático, que realizámos ao longo de mais de trinta anos, sentimos que suportamos o «futuro» daquele lugar, entretanto tornado Sítio, assumido como património cultural, reconhecido e classificado como monumento nacional.

Como apontei no início deste texto, ao explicar a sua esquematização, na primeira abordagem privilegio a investigação, o passado; na segunda defendo a prospetiva, o futuro, o que, aplicado a Tongobriga, é sinónimo de planeamento e de gestão integrada.

Este projeto de investigação, lançado no final de 1979, só foi viável porque tinha acontecido aquele 25 de Abril em 1974 e, com ele, a sementeira de ideias que desafiaram gerações.

Agora, reflito sobre um sítio cujas escavações arqueológicas, depois de feitos os indispensáveis estudos prévios, começaram em 20 de agosto de 1980, numa aldeia que encontrei em ruína.

Numa altura em que tanto se fala de partilha de responsabilidades institucionais entre o Estado e as Autarquias, saliento, e recordo, que em 1982, assumindo carácter pioneiro na relação entre o Ministério da Cultura e a Câmara Municipal, foi formalizado um protocolo de colaboração institucional que procurou criar sustentabilidade plurianual à investigação na «área arqueológica do Freixo». Desde então instalou-se na aldeia uma pequena equipa de investigação e compraram-se terrenos arqueológicos onde se comprovou, por prospeções e sondagens, a existência de ruínas.

Perante a monumentalidade e contexto científico das ruínas exumadas, logo em 1981 foi iniciado o processo administrativo de classificação, o qual foi concluído com a publicação em «Diário da República» em janeiro de 1986, salvaguardando 50 hectares como monumento nacional.

Em plena década de 80 do século XX, procuramos concentrar os atos inerentes à investigação sobre o próprio sítio arqueológico, reduzindo o movimento de peças recolhidas em escavação. Para suportar este objetivo construiu-se um laboratório para tratamento de acervos, conservação, estudo e depósito. A preocupação com a sustentabilidade técnica e científica do laboratório de Tongobriga incentivou a que formássemos técnicos e operários especializados, promovendo a empregabilidade local.

Com o decorrer dos anos foi crescendo o desafio da interdisciplinaridade e da transdisciplinaridade, assim como o intercâmbio internacional de conhecimentos e experiências.

O projeto de intervenção, desenvolvido ao longo dos anos, teve sempre o intuito de criar mais cultura e, com isso, mais identidade, mais afirmação de quem somos e, 
também, proporcionar discernimento para as opções de futuro, embora nem sempre tivéssemos conseguido tal intento perante alguma sociedade local. Procurou-se criar emprego e, com ele, maior rendimento para as famílias, mais receitas para as economias locais e regionais. Procurou-se credibilizar o papel do Estado, na medida em que lhe compete, até ao limite das possibilidades, valorizar o Património, especialmente o classificado, assumido como memória coletiva ao reconhecer as pedras que salientam as marcas seculares do homem.

Ao longo do tempo preocupamo-nos muito, também, com a divulgação do conhecimento que a investigação propiciava. Neste sentido, de entre as várias hipóteses de «valorização do património» que foram pensadas para desenvolver no Freixo até 2006, e perante as diversas metodologias que, até então, foram defendidas, decidiu-se proporcionar uma apresentação permanente de Tongobriga num «centro interpretativo polinuclear», capaz de acolher distintos públicos, quer tivessem diferentes níveis etários, quer tivessem diversos níveis académicos.

O tema fundamental do "centro interpretativo polinuclear» era a "construção milenar da paisagem pelo homem», abordada a partir de diversas perspetivas, respondendo aos desafios que a modernidade põe à sociedade do século XXI.

Projetou-se um discurso que desafiava o visitante a articular permanentemente o olhar, em plena complementaridade, em simultâneo, quer entre as «peças» expostas nas «vitrinas» e a ruína, quer entre estas e a paisagem envolvente. Por esta razão o edifício construído sobre espaços habitacionais romanos, situados a cota alta, foi predominantemente construído em vidro, privilegiando a interação visual.

Como exigência básica, de entre as várias opiniões em análise sobre «a forma de expor», foi a capacidade desse centro interpretativo ser equipado com suporte informativo, de base informática, inovador e moderno, capaz de aceitar atualizações diárias, desafiando à novidade científica. Não queríamos uma mera exposição de peças legendadas e, também, não queríamos correr o risco de ter um equipamento que soçobrasse no dia seguinte à inauguração, impedindo-nos de atualizar a divulgação do conhecimento que a investigação proporcionasse.

No discurso expositivo procurava-se, também, reintegrar em Tongobriga alguns materiais que a ela estavam associados culturalmente. Por exemplo, devia ser integrado o conjunto de miliários romanos da estrada que por lá passava, e de lá irradiava, por ser capita viarium. O Museu Nacional Soares dos Reis e a Câmara Municipal do Porto, gestora do antigo Museu Municipal do Porto, autorizaram formalmente o depósito, em Tongobriga, do miliário que integra o seu acervo. Este miliário foi recolhido em Soalhães, em 1951. Também o miliário recolhido na Quinta de Baixo, em Tuias, e que marcava a estrada romana que ligava o rio Tâmega a Tongobriga, deveria ser aqui depositado.

Inicialmente armazenado no museu municipal no Marco foi, no entanto, enviado em 2005 para o Museu da Pedra em Alpendurada, onde não está inserido no seu 
contexto histórico, embora esteja integrado no conjunto de peças graníticas. Embora estes dois marcos tivessem sido recolhidos sem contexto arqueológico, a nossa investigação proporcionou a sua reconstituição, localização e enquadramento. Julgo que este trabalho de reajustamento e valorização das marcas deixadas pelo homem ao longo dos séculos devia ser uma preocupação permanente, não só dos investigadores, historiadores, arqueólogos e museólogos mas, também, dos responsáveis políticos.

Mas, para além da investigação e da exposição de resultados científicos, a dimensão patrimonial de Tongobriga exigia gestão integrada de todo o espaço classificado e do território envolvente.

Perante esta necessidade evidente e justificando-se pela importância que atribuímos ao planeamento global das atividades de investigação, de dinamização expositiva e cultural, para além da fruição qualificada das ruínas de Tongobriga, no início do século XXI juntaram-se arqueólogos, arquitetos, técnicos de conservação, técnicos de sistemas informáticos, entre outros cidadãos especialistas de diversas áreas do conhecimento.

Procuramos desenvolver reflexão sobre a valorização global do sítio classificado e salientaram-se duas opções, resumidamente apontadas como «concentração» de infraestruturas num único edifício de apoio ou a «dispersão» em diversos edifícios de menores dimensões.

No projeto global assumiu-se, como fundamental, a «diluição» das infraestruturas de valorização pelos 50 hectares classificados como monumento nacional, quer fossem recuperações integradas no núcleo construído da aldeia, quer fossem construções novas implantadas em harmonia com a malha urbana romana que tinha sido identificada durante a nossa investigação.

Depois de analisadas as várias hipóteses técnicas e metodológicas, foi decidido desenvolver em Tongobriga um sistema de valorização suportado, prioritariamente, na recuperação de pequenos edifícios dispersos no espaço classificado, e que respondessem às diversas necessidades. Em simultâneo, no caso de insuficiência, ou desadequação, dos edifícios existentes, foi decidido projetar construções novas. $\mathrm{O}$ sítio exigia uma receção para acolhimento dos visitantes, um auditório para cerca de 80 lugares, um núcleo expositivo sobre a vida quotidiana (edificado sobre área habitacional), um núcleo expositivo sobre o ritualismo da morte (edificado sobre a necrópole de cremação), uma oficina para apoio técnico, uma reserva para espólio arqueológico e, ainda, um restaurante. Apesar de, aparentemente, serem projetos óbvios, realçamos algumas especificidades das intervenções neste sítio patrimonial. Por exemplo, nesta aldeia não existe saneamento básico e, por isso, a construção de sanitários públicos, de qualidade, tornou-se em peça de arquitetura específica e complexa porque todo o subsolo tem ruínas.

Realço a intransigente defesa da perspetiva de reversibilidade em todas as intervenções contemporâneas, por mais reduzidas que sejam as infraestruturas a construir. 
Realço, também, que a importância de um sítio arqueológico é tanto maior quanto mais fortemente contribua para o aumento do conhecimento do homem e, por isso, todo o revolvimento de solos ou de edifícios foi salvaguardado por prévia escavação arqueológica, inserida na investigação permanente, suporte indispensável e prioritário em toda a abordagem ao território, por mais reduzida que pareça ao cidadão leigo.

No planeamento feito até 2013 estava assumida, como fundamental, a preocupação com a investigação, de campo e laboratorial, em simultâneo, buscando a reconstituição da paisagem antiga, materializada, depois, em projetos de reconstituição e de reabilitação. Procurava-se promover a fruição qualificada que permitisse perspetivar, e valorizar, a memória para distintos públicos.

As intervenções em Tongobriga desenrolaram-se, em contínuo, ao longo de mais de três décadas e, por essa razão, é fundamental avaliar, criticar com rigor, viabilizando perspetivas de futuro realistas.

Neste sentido, pensar o «futuro» de Tongobriga merece empenhamento estratégico, quer de âmbito científico, quer de âmbito financeiro e político.

Os 50 hectares classificados, assim como os envolventes, continuam e exigir preocupações de gestão, quer de caráter administrativo que o salvaguardem e ampliem, quer de caráter científico que reforcem a sustentabilidade do conhecimento, quer de caráter técnico que garantam a conservação de ruínas e espólios arqueológicos, quer de caráter divulgativo que garantam a apresentação do conhecimento, quer de caráter museológico que valorizem os desafios expositivos.

Algumas das preocupações, embora sintetizadas, podem apontar para algumas medidas. Proponho algumas medidas que, a título de exemplo, julgo oportunas.

Todos os terrenos situados no interior da área classificada como monumento nacional deveriam ser intransigentemente defendidos, quer aplicando medidas que impeçam os revolvimentos descontrolados dos solos, limitem a florestação e o uso para qualquer fim agrícola. São terrenos onde existem ruínas e valores arqueológicos que não podem ser afetados, mesmo que parcialmente.

É fundamental que se façam escavações arqueológicas nos terrenos das encostas norte, nascente e poente, onde existem ruínas evidentes de habitações. Estas escavações permitirão aprofundar e esclarecer muitas dúvidas que existem sobre as cronologias e as fases de construção do "castro" e da cidade. Recordo que na encosta nascente, onde foi construído, sobre ruínas, um tanque privado para combate a incêndios e onde foi feita intensa florestação, existem testemunhos evidentes de ruínas que ainda podem ser recuperados, apesar do revolvimento dos solos e da afetação que tal provocou nas estratigrafias arqueológicas.

Os terrenos situados a norte, quando escavados, poderão proporcionar conclusões sobre os alinhamentos do urbanismo, certamente reconhecido por novas domus e outros edifícios. 
Os trabalhos de escavação dos espaços do eventual teatro, ou anfiteatro, foram injustificadamente interrompidos em 2013. Julgo que o aprofundamento desta investigação deveria ser prioritária na medida em que é determinante para a definição do estatuto da cidade romana.

Também as ruínas da basílica paleocristã exigem que a escavação arqueológica seja retomada. Estas ruínas, que estão debaixo da atual Igreja Paroquial do Freixo, foram interpretadas como sendo da basílica mais antiga da Diocese do Porto.

A valorização da ruína desta basílica paleocristã obrigará a escavar, com metodologia arqueológica, todos os terrenos do adro sul, para além de obrigar a intervir, de novo, no interior do edifício, procurando recuperar as ruínas, e os mosaicos, que ainda existam. Estes vestígios são demasiado importantes para a cultura, e para a religião, para que permaneçam em más condições de conservação, debaixo do soalho. A perspetiva redutora que existiu, impedindo boas soluções, tem que ser substituída por uma intervenção inteligente e cientificamente arguta que dignifique o sítio e o seu significado.

Num sítio como Tongobriga, onde as condições técnicas existentes facilitavam a escavação sistemática durante vários anos, acumularam-se observações estratigráficas e os correspondentes materiais referenciados. Nestas condições torna-se prioritário o desenvolvimento o estudo de «todo» o espólio, quer o existente em arquivo, quer o armazenado nas reservas. Apenas alguns milhares das peças integraram as estratigrafias que foram selecionadas para publicação em 1995 e em 1997. Muito trabalho de laboratório tem que ser desenvolvido e, certamente, as modernas metodologias transdisciplinares poderão proporcionar novos conhecimentos.

Também poderiam ser reajustadas as estratégias de valorização e de uso de Tongobriga.

Por exemplo, o espaço envolvente do restaurante, junto do forum e das termas merece reflexão. Para que possamos compreender melhor aquele espaço, situado a nascente do forum, é fundamental que seja feita a escavação arqueológica dos solos que estão sob o traçado da atual estrada municipal, pavimentada com cubo granítico. Ao mesmo tempo, será fundamental pensar no seu desvio, proporcionando cuidadosamente um novo perfil de "via rural», eventualmente traçada no lado nascente do restaurante. É uma estrada dentro de um sítio arqueológico único e, por isso, condicionada à existência de ruínas, as quais devem ser assumidas como prioritárias.

Neste espaço envolvente do forum é fundamental demolir a totalidade das construções abarracadas, espúrias, que ali vão teimosamente permanecendo contra as lógicas ambientais, e cívicas, exigidas num sítio classificado como monumento nacional.

Também a investigação realizada nos terrenos situados a sul do forum já permite reajustar as perspetivas interpretativas que existiam para o traçado da estrada romana. Parece agora evidente que o traçado da via romana corresponde ao que ainda existe como estrada municipal, embora o piso original, talhado no penedo granítico, esteja sob o atual pavimento empedrado com cubos de granito. Em contrapartida, 
julgo, agora, dever alterar uma interpretação que apontara para a existência de uma estrada romana pelo monte, confundida com trilhos que existem, bem marcados, no afloramento granítico. Não temos comprovação de que esses trilhos sejam romanos. Foram feitos pelos rodados dos carros que cruzaram o monte em várias direções para transportarem a pedra «roubada» das ruínas em períodos medievais e posteriores. Ao percorrer esses trilhos os carros sobrepuseram-se e pisaram vestígios de sepulturas romanas de cremação, evidenciando o uso dos solos post quem aos enterramentos. Provavelmente, quando passavam com os carros por cima, carregados de pedra retirada das ruínas, os homens, medievais ou modernos, não sabiam o que ali tinha existido.

As autoridades nacionais e regionais que tutelam o Património Cultural devem ter a coragem de reconhecer os desafios permanentes com que estão confrontados. Neste sentido será importante que reconheçam que devem ser reinterpretadas, e redimensionadas, com audácia, as perspetivas museológicas que Tongobriga pode propiciar.

Neste sentido, julgo que é importante redimensionar qualitativamente a receção dos visitantes, especialmente os que abordam o sítio arqueológico pelo lado sul, onde se identificam os espaços das necrópoles de cremação.

Também a escavação destas necrópoles deveria ser ampliada até ao limite do espaço classificado, quer nos espaços envolventes da antiga escola primária quer, principalmente, nos terrenos envolventes da serração onde, recentemente, foram feitos cortes de árvores.

Mas, o redimensionamento das perspetivas museológicas de Tongobriga merecia que esta cidade romana fosse lida em plenitude com os territórios envolventes, com plena transparência entre a luz natural, os espólios, as ruínas e a paisagem milenar. E isto não se consegue com tradicionalismos que metem peças arqueológicas em vitrinas iluminadas por estarem em salas escurecidas artificialmente, mesmo que para tal tivessem que ser alterados os projetos iniciais aprovados.

A ousadia de perspetivar o futuro não é apanágio do arqueólogo, mesmo que seja assumida como mera proposta de trabalho sobre um sítio arqueológico, mesmo que seja uma forma de olhar o mundo em processo de mudança. Mas para o arqueólogo o reconhecimento do impacto nas sociedades, e dos cidadãos, é um desafio. A dificuldade de gerir o ciclo de crescimento e, cada vez mais, o ritmo da informação, parece complicar a governação do futuro.

Em contrapartida, as décadas de investigação científica sobre o território de Tongobriga incentivam a luta em defesa da reinvenção cultural dos sítios patrimoniais, exaltando a descoberta permanente que a arqueologia, enquanto ciência, proporciona, dimensionando os nossos desafios do quotidiano e a descoberta da arquitetura espacial dos territórios. 
O reconhecimento do trabalho milenar que o homem desenvolveu sobre um território é a prova de que há sempre amanhã. Os ensinamentos reconhecidos propõem que amanhã tudo estará melhor.

Investigar um sítio, um território, permite conhecer mais e melhor, e isso é uma tarefa para a vida inteira.

\section{BIBLIOGRAFIA}

CHARLES, Rocha; DIAS, Lino; ALARCÃO, Pedro (2015) - Tongobriga Reflexões sobre o seu Desenho Urbano. Porto: CITCEM/Afrontamento.

COSTA, L.; PACHECO, E., SOARES, L., TAVARES, L. (2014) - O uso inteligente do território para a mobilidade na romanização. In Actas XIV Colóquio Ibérico de Geografia, Guimarães: [s.n.].

DIAS, Lino Tavares (1997) - Tongobriga. Lisboa: Instituto Português do Património Arquitectónico Ministério da Cultura.

(2007) - Paisagem, Tempo, Memória na região norte de Portugal. In VARELA CAMPOS, Paz, coord. - IV Congresso Internacional sobre Musealización de Xacementos Arqueolóxicos: conservación y presentación de xacementos arqueolóxicos no medio rural. Santiago de Compostela: Xunta de Galicia, p. 37-46.

(2010) - Povoamento Romano na Bacia do Douro: A criação de cidades. Tongobriga e o Territorium. In Atas Colóquio Internacional "Patrimonio Cultural y território en el Valle del Duero. Zamora 28-30 marzo 2007. Valladolid: Junta de Castilla y León, p. 33-52.

MARTINS, Manuela; RIBEIRO, Jorge (2018) - O urbanismo de Bracara Augusta: modelo e especificidades no contexto do NO peninsular. In DIAS, Lino Tavares, coord. - Construir, navegar, (re)usar o Douro da Antiguidade. Porto: CITCEM.

VELOZO, Francisco José; CARDOSO, José, ed. (1965) - Estrabão: Livro III da «Geografia» - Primeira contribuição para uma nova edição crítica. Porto: Centro de Estudos Humanísticos. (Studium Generale Amphitheatrum, IX).

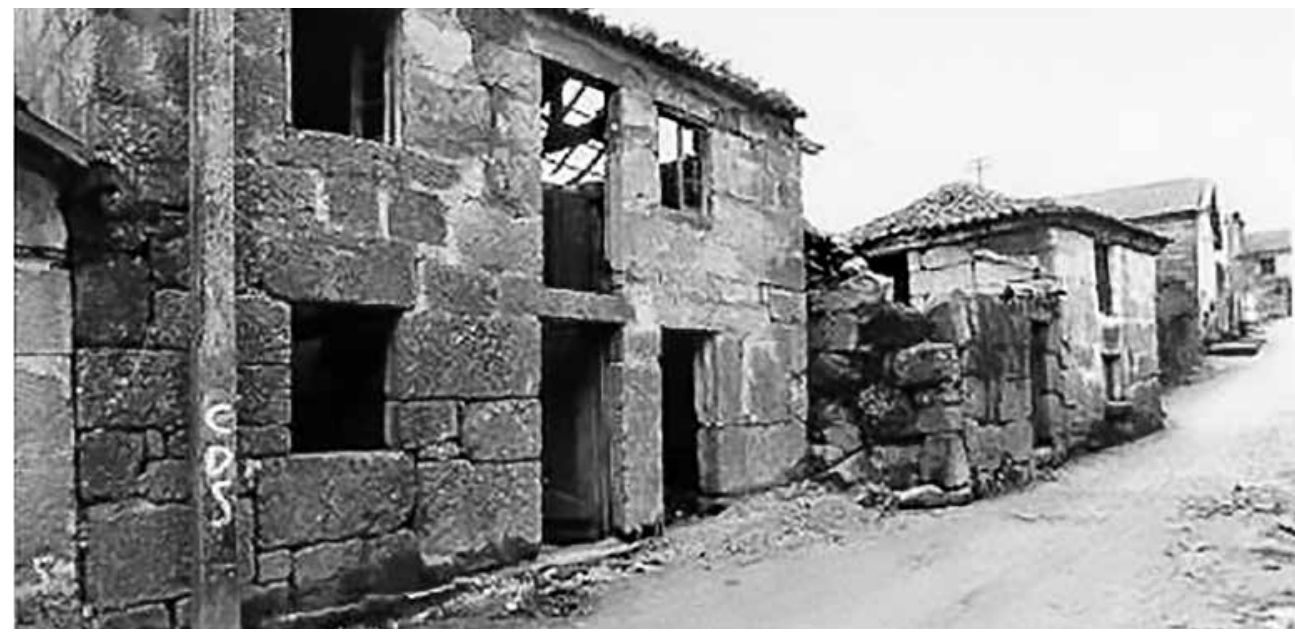

Fig. 1. Depois de realizados os indispensáveis estudos prévios, as escavações arqueológicas começaram em 20 de agosto de 1980, no lugar da «capela dos mouros», da aldeia do Freixo, que encontrei com várias casas em ruína. 


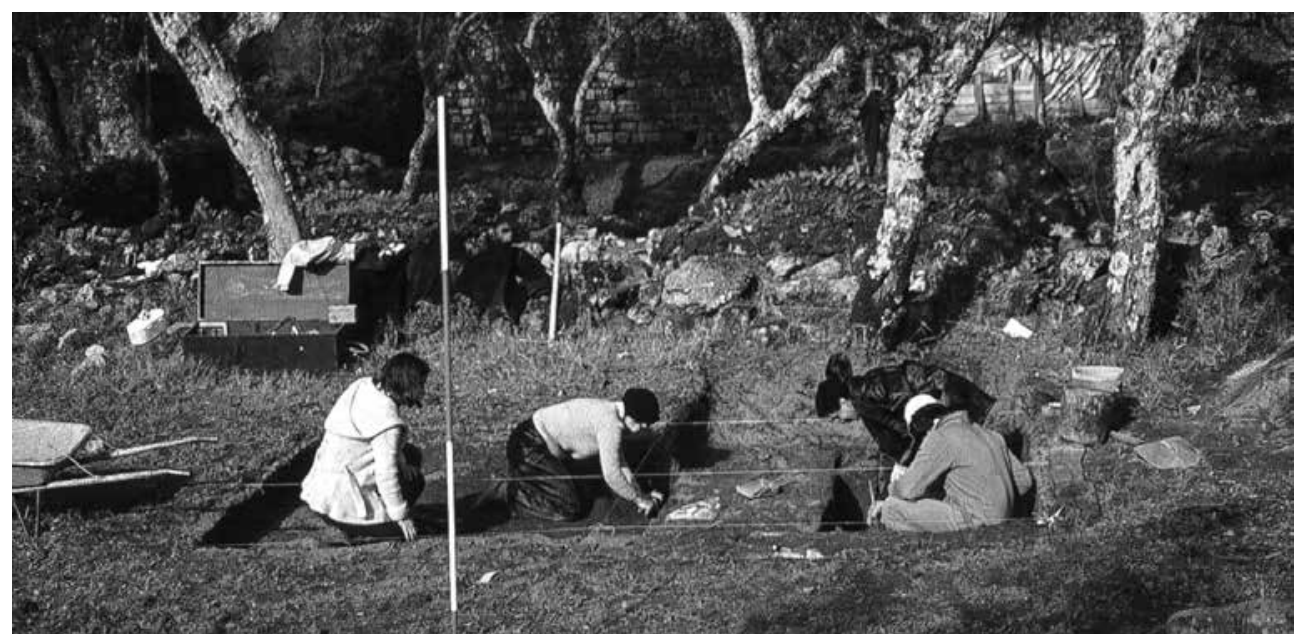

Fig. 2. As primeiras sondagens e escavações, em 1980, foram feitas no lugar conhecido por «capela dos mouros», em terrenos usados para olival e para plantação de milho.

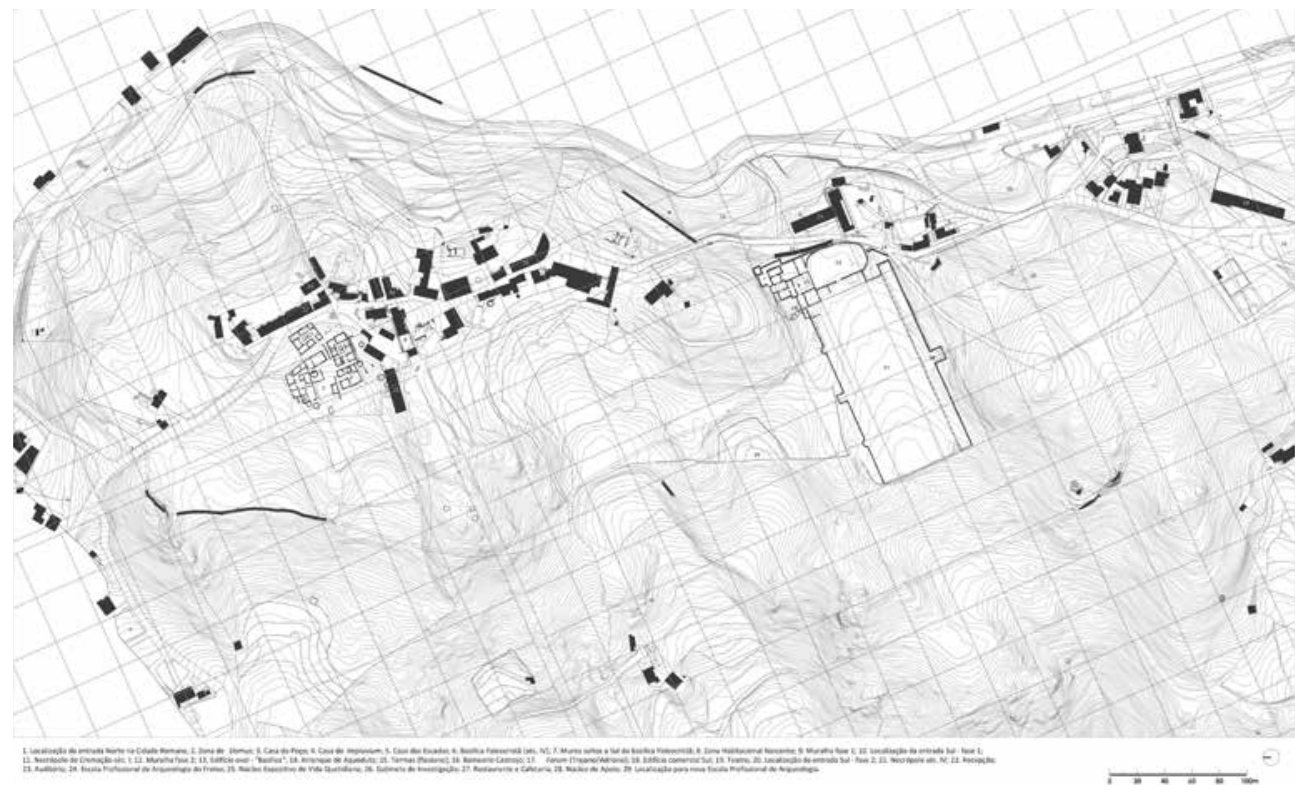

Fig. 3. No final do século I a. C., e no início do século I d. C., foi construído um castro ex nihilo, com muralha de troços retilíneos. Junto dela, no lado exterior, a sul, foi construído o balneário do tipo pedra formosa. $\mathrm{Na}$ área interior da muralha, com cerca de 13 hectares $\left(138.000 \mathrm{~m}^{2}\right)$, foram identificadas casas de planta circular, de arquitetura tradicional, construídas em granito e cobertura em colmo.

No final do séc. I d. C. foi feita a implantação do Actus Quadractus, assumida como estruturação da cidade que vai sentir-se no início do século II. A muralha foi ampliada, de modo a integrar os novos espaços públicos monumentais, embora salvaguardando a continuidade da necrópole de cremação, já existente, e que, assim, se manteve no exterior do novo traçado. A área global de espaço intramuralha passou para cerca de 21 hectares $\left(21.650 \mathrm{~m}^{2}\right)$. 


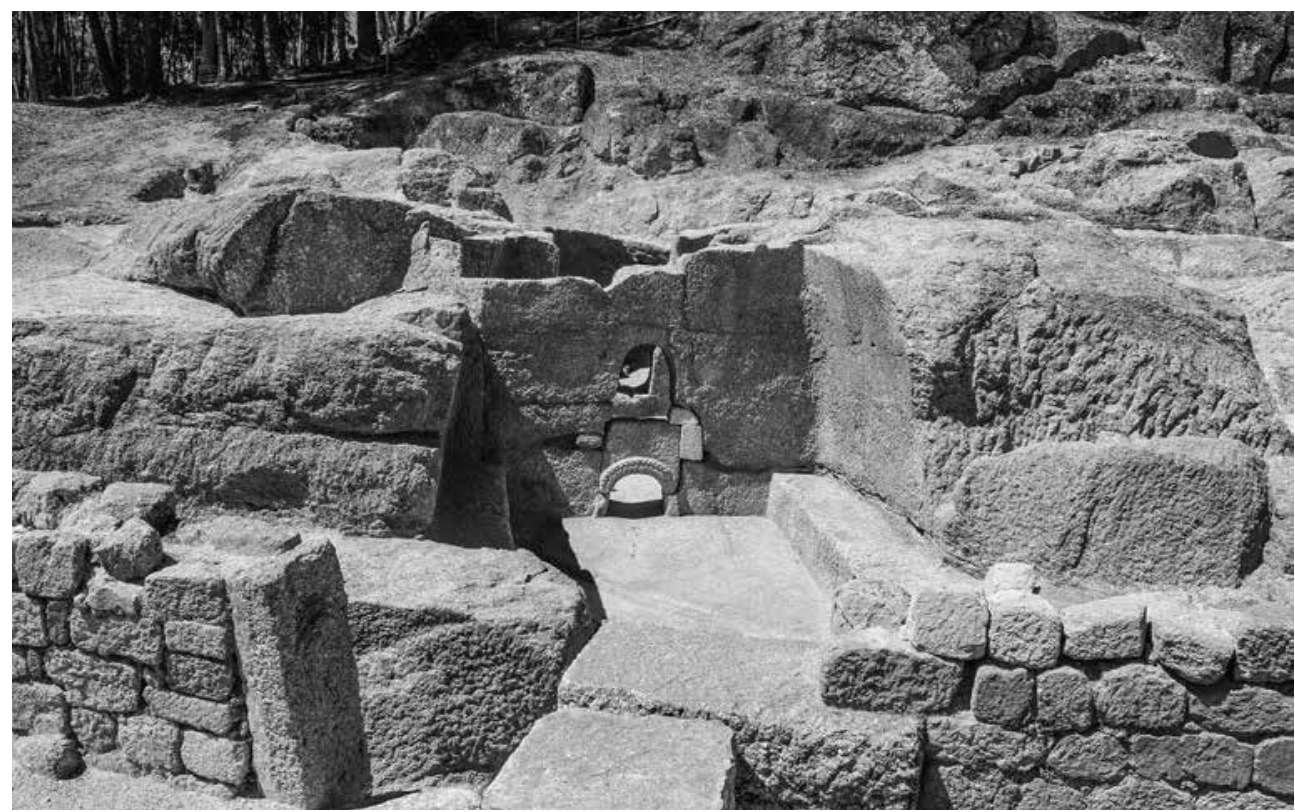

Fig. 4. No final do século I a. C. e no início do século I d. C. foi construída uma muralha com troços retilíneos. A área interior da muralha, onde foram identificadas casas de planta circular, era de cerca de 13 hectares $\left(138.000 \mathrm{~m}^{2}\right)$. Junto desta muralha, no lado exterior, no final do século I a. C., foi construído um balneário de tradição indígena, totalmente escavado na rocha, confirmando o que Estrabão escreveu sobre os povos do noroeste da Ibéria: «Dos que habitam junto do rio Douro, alguns... juntam-se duas vezes ao dia e tomam banhos de vapor que fazem com pedras ao rubro». Fonte: VELOSO \& CARDOSO ed., 1965.

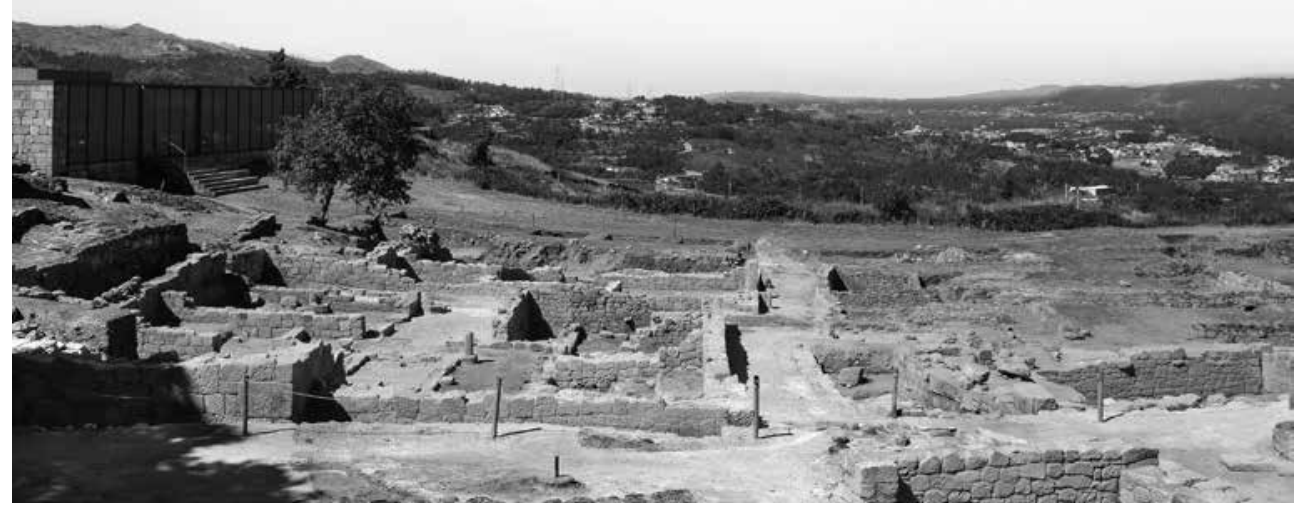

Fig. 5. Nos espaços habitacionais a fase de urbanização realizada no início do século ll obrigou à desmontagem das casas construídas no século I. Sobre os alicerces das casas de planta circular a arquitetura romana construiu de acordo com a ortogonalidade dos actus quadratus, em espaços que permitiam observar as paisagens envolventes. Foi este espaço que serviu, já no século XXI, para instalar o núcleo expositivo sobre a vida quotidiana de Tongobriga, onde se procurava valorizar, naturalmente, a relação com as paisagens envolventes. 
Fig. 6.

O enquadramento do Forum e das Termas, ambos construídos no final do século I e início do século Il, seguiu com rigor a implantação regulada pelo

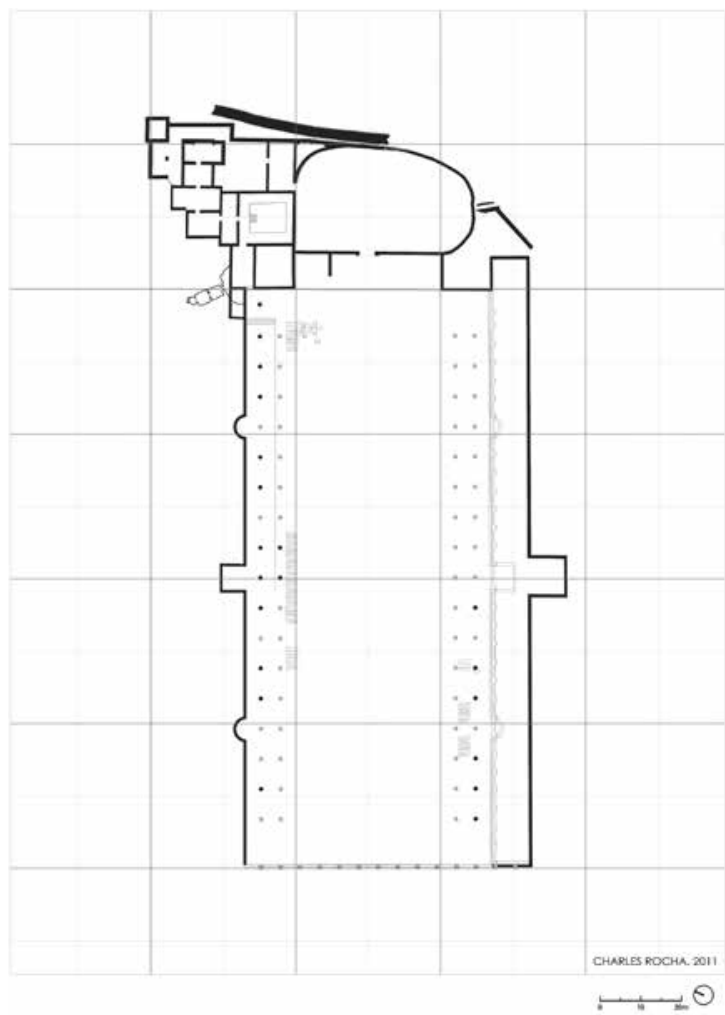
Actus Quadractus.

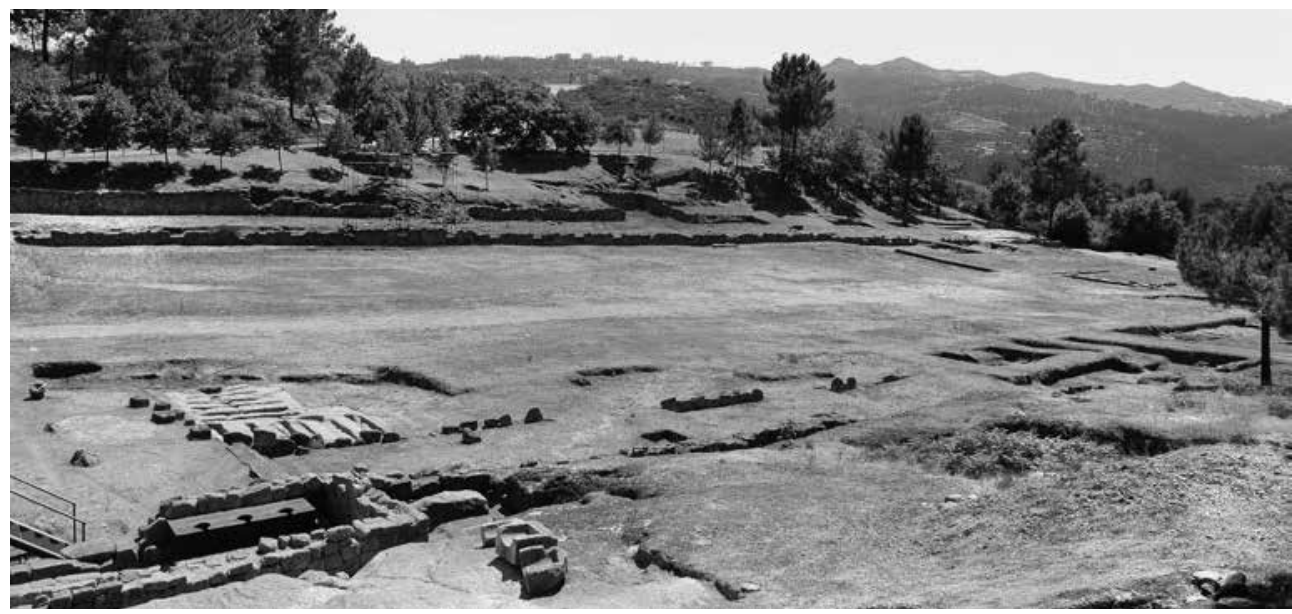

Fig. 7. Em Tongobriga, tal como fizeram em todas as cidades do Império, os romanos construíram um Forum, assumido como centro da cidade onde construíram edifícios religiosos, administrativos e comerciais, em torno de uma praça central.

O conjunto monumental, edificado a partir da governação de Vespasiano, ocupava cerca de $10.000 \mathrm{~m}^{2}$, implantado rigorosamente no desenho urbano cuja matriz foi o actus quadratus. 


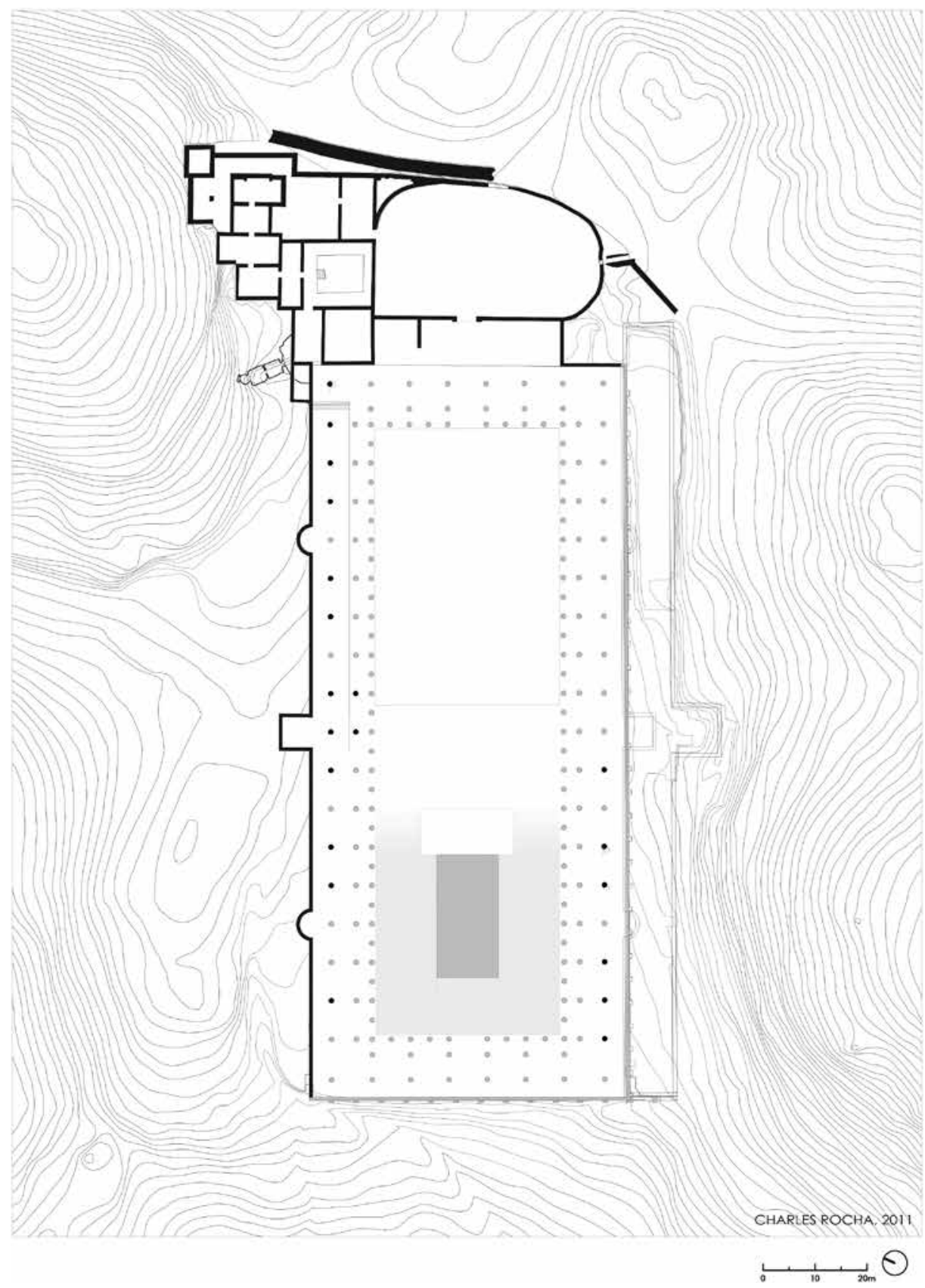

Fig. 8. Reconstituição do Forum. O desenho, que resultou da análise dos elementos identificados em escavação arqueológica, permite afirmar que era um espaço marcado por quatro pórticos de três colunas. $\mathrm{O}$ corpo central do Forum dividia-se em dois espaços: a praça de 1 actus de largura e 1,5 actus de comprimento, e o templo. O eixo central, que separava os dois espaços, era marcado pela relação visual entre as duas absides quadradas, situadas nos lados norte e sul do Forum. 


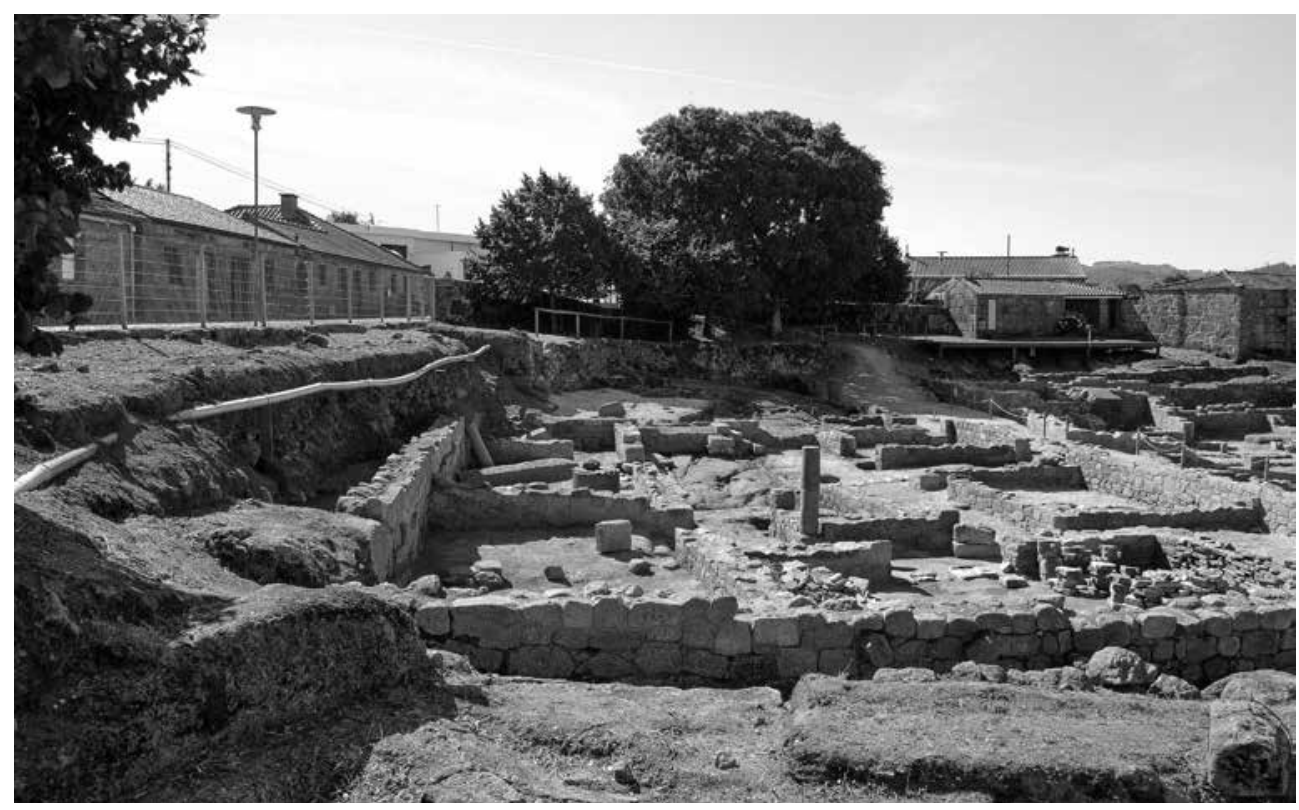

Fig. 9. A pequena aldeia do Freixo instalou-se, ao longo dos séculos, predominantemente, sobre espaços habitacionais da cidade de Tongobriga, reaproveitando muita pedra das suas ruínas.

Fig. 10.

A escavação arqueológica, e a observação topográfica, permitem induzir a existência de uma muralha que ampliou o espaço urbano do século I. O trabalho intenso de talhe dos afloramentos graníticos permitem apontar alguns dos traçados dessa eventual muralha, assim como permite localizar algumas das eventuais

«portas».

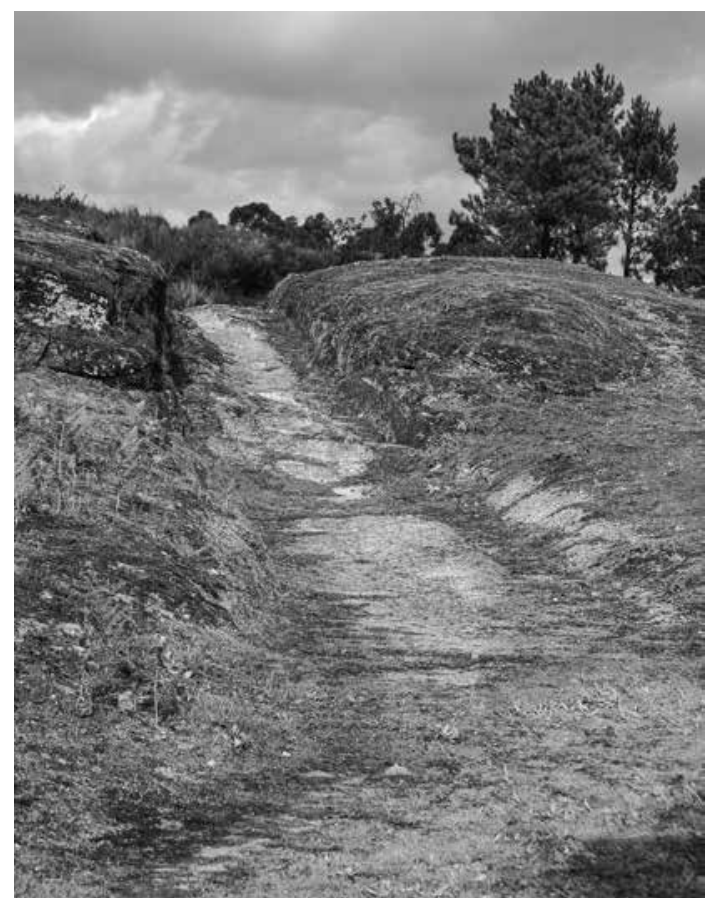




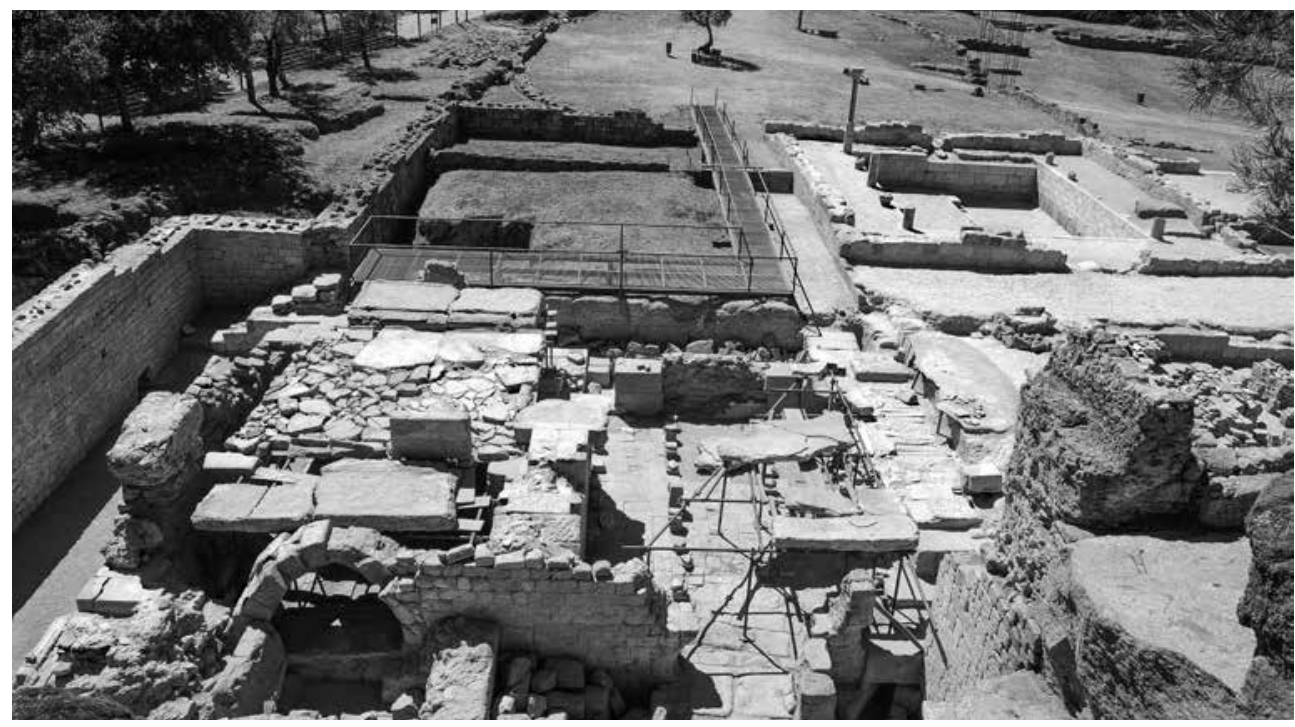

Fig. 11. O edifício das termas, cuja parte coberta ocupava um actus quadratus. Foi implantado de acordo com o plano urbano da cidade, em época de governação de Vespasiano. O projeto do edifício foi desenhado com base na proporção do passus, em todas as salas (frigidarium, tepidarium, caldarium, apoditerium), nos corredores e nas salas de apoio ao funcionamento.

A estrada municipal que atravessa a aldeia do Freixo sobrepõe-se em quase todo o seu traçado a ruas e ruínas romanas e, nesta zona das termas, está, com grande probabilidade, sobreposta às ruínas do troço tardio da muralha que, ali, demarcava os espaços de enterramento, evidenciados pelas necrópoles de cremação identificadas com cronologias desde o século I até ao IV, e cuja investigação é fundamental.

A alteração do traçado da estrada permitirá determinar a riqueza arqueológica de todo o espaço.

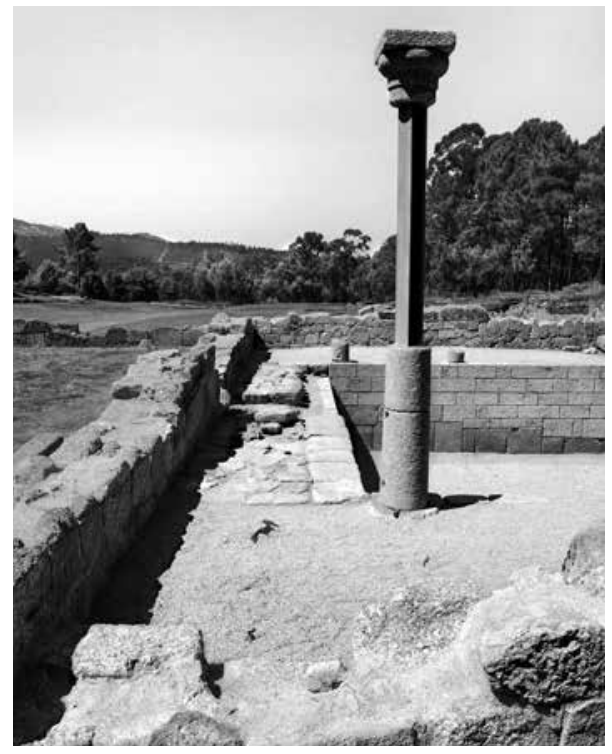

Fig. 12.

No século II, em tempo da governação de Marco Aurélio, o espaço da palestra das termas foi ocupado com a construção de uma natatio, piscina ao ar livre, também respeitando a proporção do passus. 


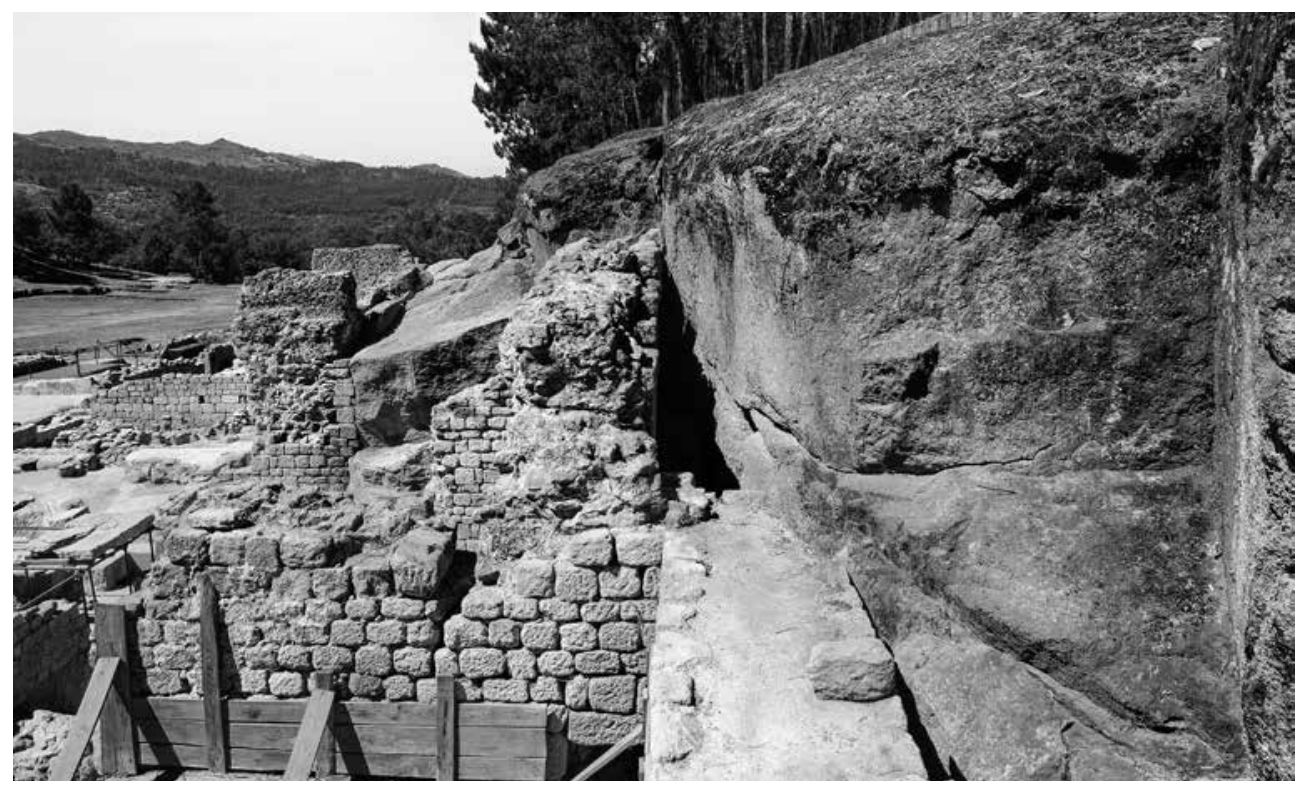

Fig. 13. Em toda a cidade é notório o trabalho de talhe dos afloramentos graníticos para servirem de alicerce dos edifícios. No caso das termas também é notória a construção contrafortada, diretamente adossada ao afloramento adequadamente talhado.

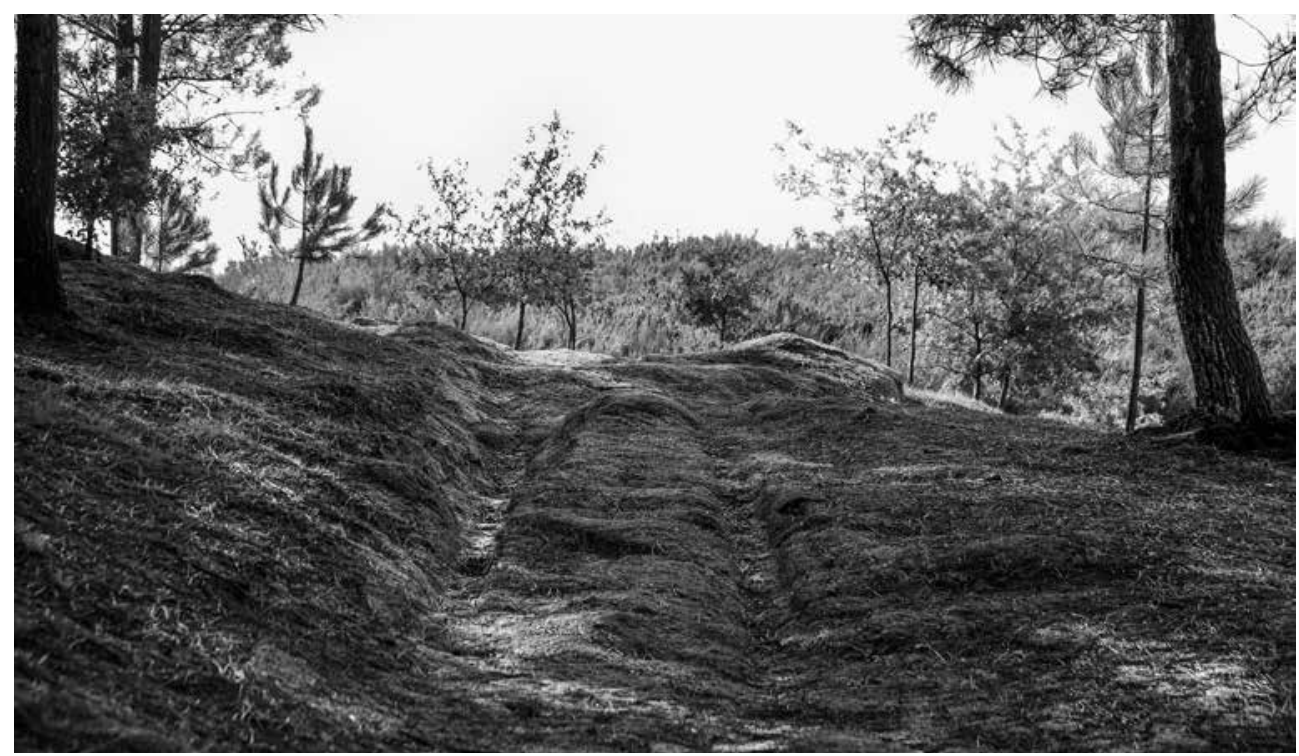

Fig. 14. Nos afloramentos graníticos nas zonas situadas a sul do forum também foram identificados muitos talhes. Embora sejam de interpretação difícil, julgo tratar-se de sulcos provocados pelos carros de bois que ali foram carregar a pedra, em momentos de cronologia incerta, medieval ou posterior, quando «roubaram» muita pedra das ruínas do forum. 


\title{
COMPRENDER LA CIUDAD A TRAVÉS DE LA ARQUITECTURA: CLUNIA Y TIERMES
}

\author{
MIGUEL ÁNGEL DE LA IGLESIA SANTAMARÍ** \\ GERARDO MARTINNEZ DIEZ**
}

\section{INTRODUCCIÓN}

La ciudad romana de Clunia, situada en el denominado Alto de Castro junto a la Localidad de Peñalba de Castro en Burgos, constituye un yacimiento arqueológico fundamental para comprender la historia del paso de Roma por el valle del Duero, sus referencias en la fuentes, especialmente su condición de capital de convento jurídico, o su protagonismo en el momento de la comunicación de la proclamación de Galba como emperador, han ido siempre acompañando al nombre de la Ciudad COLONIA CLVNIA SVLPICIA. Sus restos sin embargo, han estado presentes durante dos milenios, desplazándose sus fragmentos a otras localidades, configurando iglesias, castillos y casas durante toda la edad media y moderna hasta quedar reducida a una simple traza de apenas unos centímetros de espesor, pero que a modo de palimsesto, permite a medida que vamos redescubriendo su huella bajo tierras de cultivo, entender la magnitud de su implantación, la calidad de sus edificios y espacios urbanos y nos brinda la oportunidad de reconstruir la vida de la ciudad en un pasado tan remoto, entender la función que desempeñaba en el sistema organizativo del territorio y finalmente descubrir los motivos que originaron su declive adaptándose a una vida para la que no había sido diseñada.

\footnotetext{
* Universidad de Valladolid. iglesia@arq.uva.es.

** Universidad de Burgos. gerardomartinezdiez@gmail.com. Yacimiento Arqueológico de Clunia.
} 


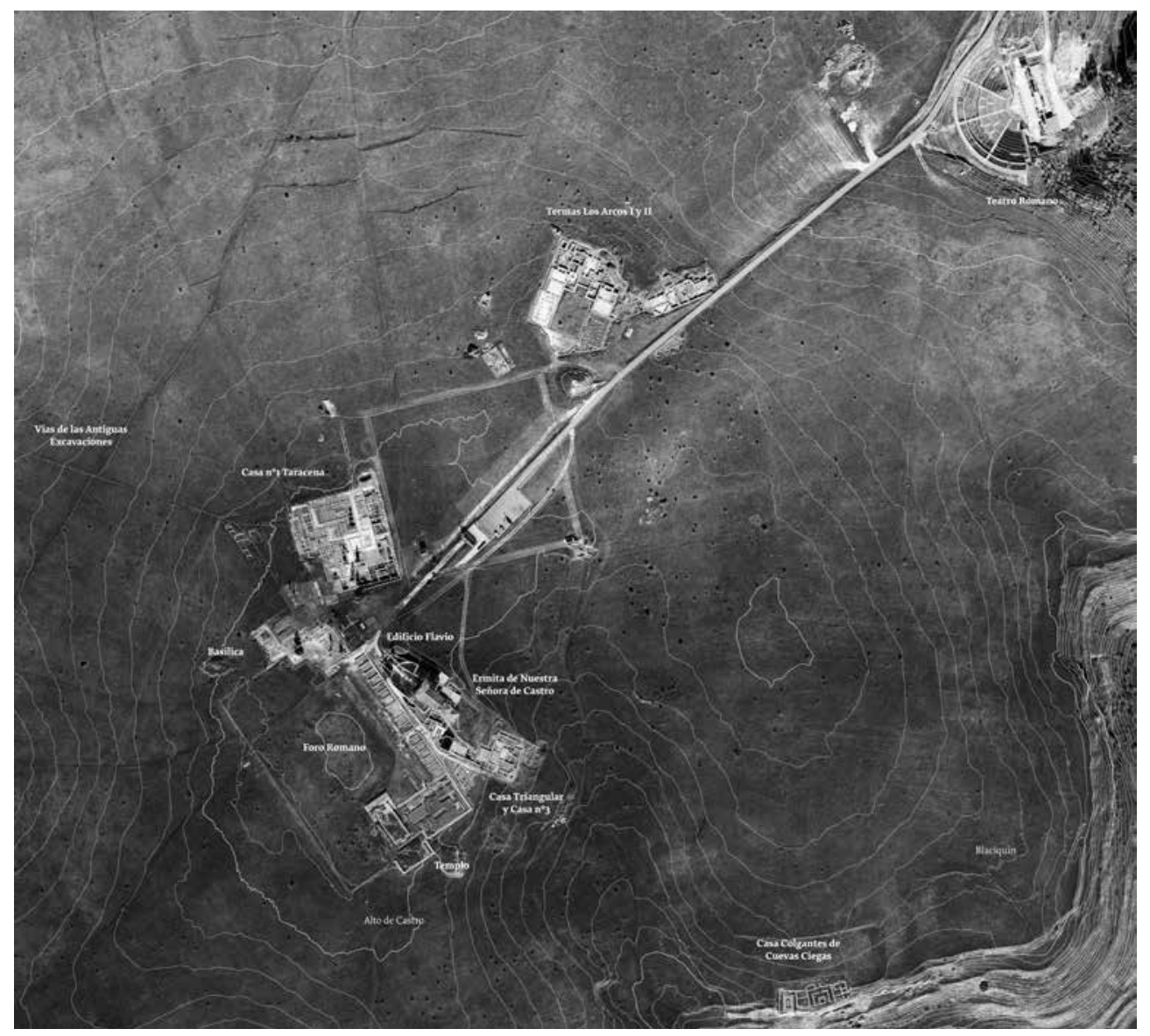

Fig. 1. Ortofoto del área central de Clunia.

La ciudad de Clunia, en una primera visión, parece responder, con la organización de sus espacios públicos, a las necesidades de un municipio romano convencional, sin embargo si analizamos de forma más pormenorizada la geometría, escala y composición de los conjuntos arquitectónicos más representativos, Foro, Teatro y Termas, veremos que existe un sobredimensionamiento excesivo y algunas particularidades que difieren de las habitualmente encontradas en ciudades del mimo tipo. Ello nos lleva a pensar que se trata de una ciudad que como consecuencia de asumir la condición de capital de convento, transforma su estructura urbana e incorpora un diseño del espacio público, amortizando los espacios que hasta ese momento habían dado servicio a las funciones de municipio. 


\section{LA ARQUITECTURA DE CLUNIA}

Palol, excavó en distintas fases el foro de Clunia ${ }^{1}$, encontrando y definiendo los elementos característicos del mismo, el podio del templo ya visible con anterioridad, tabernas en los laterales, recinto religioso en torno al templo y la basílica jurídica, situada en el lado opuesto al templo. La reconstrucción del conjunto se hizo de acuerdo al esquema de los modelos habituales de foros municipales, salvo por las dimensiones, o mejor dicho, por las proporciones entre sus elementos. Su comparación con otros foros municipales podía servir para establecer la tipología arquitectónica pero presentaba serias dudas desde la proporción de sus elementos, así como desde la escala de intervención ${ }^{2}$.

Por otro lado, en las excavaciones realizadas en el cardo Este, que delimita el conjunto del Foro, aparecieron las pruebas claras de la existencia de un tejido urbano previo, que tuvo que ser recortado para introducir el nuevo conjunto forense, lo que demuestra la existencia de una ciudad plenamente romana, sobre la que se le instala un foro de grandes dimensiones y con un particular diseño.

La existencia de la canaleta de recogida de aguas del pórtico, la cimentación de un pedestal monumental en eje con una cisterna y ciertos muros, obligaban a repensar el conjunto con un espacio mas ajustado al templo con los pórticos generando mas superficie cubierta, lo que se verificó con la aparición de los apoyos de una nueva línea de columnas paralela ala documentada por Palol y de ritmo similar, confirmando una nueva concepción de la plaza, de un tamaño mucho más adecuado a las proporciones de los edificios que la configuraban y en la misma medida el espacio vinculado a las

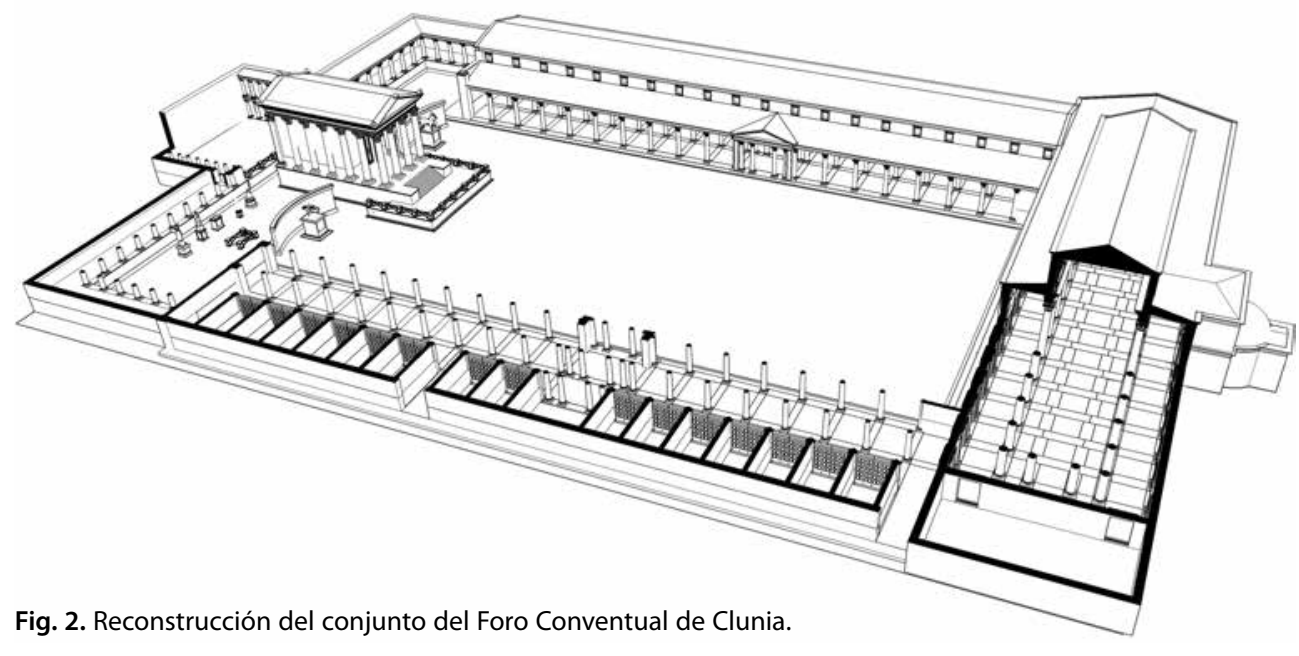

${ }^{1}$ PALOL \& GUITART, 2000.

${ }^{2}$ DE LA IGLESIA \& TUSET, 2013. 
tabernas aumentaba al pasar de un simple soportal de circulación, a un doble pórtico, seguramente con función de mercado eventual.

El templo se encuentra presidiendo la plaza pública. La escalera de acceso al pronaos, apoya sobre un podio intermedio a modo de tribuna sobre el espacio del foro, a la que se accede por dos escaleras laterales que descienden hacia la parte trasera del templo, evitando la conexión directa desde la plaza.

La plaza del foro queda cerrada en sus extremos Norte y Sur por la basílica y el recinto religioso, ocupando en ambos casos toda la dimensión del conjunto. La zona religiosa tras el templo se encuentra perfectamente delimitada y separada del espacio público mediante dos muros curvos precedidos de sendas estatuas sobre un gran pedestal rectangular, ocultando tras de sí una cisterna enterrada, con un uso que va más allá del mero depósito de agua, pudiéndose tratar de elementos vinculados al uso ritual. Estanques y depósitos a ambos lados de los templos, aparecen frecuentemente, como es el caso del foro municipal de Mérida o el de Évora. El recinto religioso queda definido por dos pórticos simples a ambos lados del templo, realzados sobre el pavimento de la plaza y que se articulan en el centro a través de un gran espacio inmediatamente detrás del templo, a modo de aula abierta, que remata todo el eje principal de la composición del conjunto del foro.

La basílica ocupa todo el ancho del foro en el lado opuesto al templo, cerrando el lado Norte. En el centro de la misma coincidiendo con el eje principal de todo el conjunto se encontraba en origen una pequeña dependencia a modo de ábside con nicho central, donde seguramente se situaba la estatua representativa del emperador y tal como propone Palol, serviría de Curia. Esta dependencia aparece rápidamente sustituida a lo largo del siglo I por un edificio monumental conectado con la basílica en el mismo punto y de grandes dimensiones, donde posiblemente se podían reunir los magistrados y albergar la representación de la familia imperial, culto ya extendido, y que sabemos que tenía un ceremonial concreto. De hecho a lo largo del siglo primero se constituirían reuniones del convento en la capital del mismo (concilium conventus), lo que seguramente obligó a transformar esta primera celda en una auténtica Aedes Augusti/Curia, donde poder celebrar estas reuniones.

El conjunto forense de Clunia, en su manifestación arquitectónica, representa el perfeccionamiento de una tipología suma de dos modelos comúnmente adoptados a lo largo de la geografía del mundo romano, en lo que a la definición del espacio comercial se refiere. Por un lado se encuentran los foros constituidos a base de tabernas, normalmente precedidas de un pórtico de circulación que facilita su uso a cubierto de las inclemencias, bien sea el sol o la lluvia. Por otro lado existe el modelo de pórtico abierto, muchas veces sin tabernas donde se puede realizar una actividad comercial, más abierta, no vinculada a puestos fijos de venta sino, más bien, diseñados para mercados ambulantes o feriales, como el llamado Pórtico de Livia en Roma. 


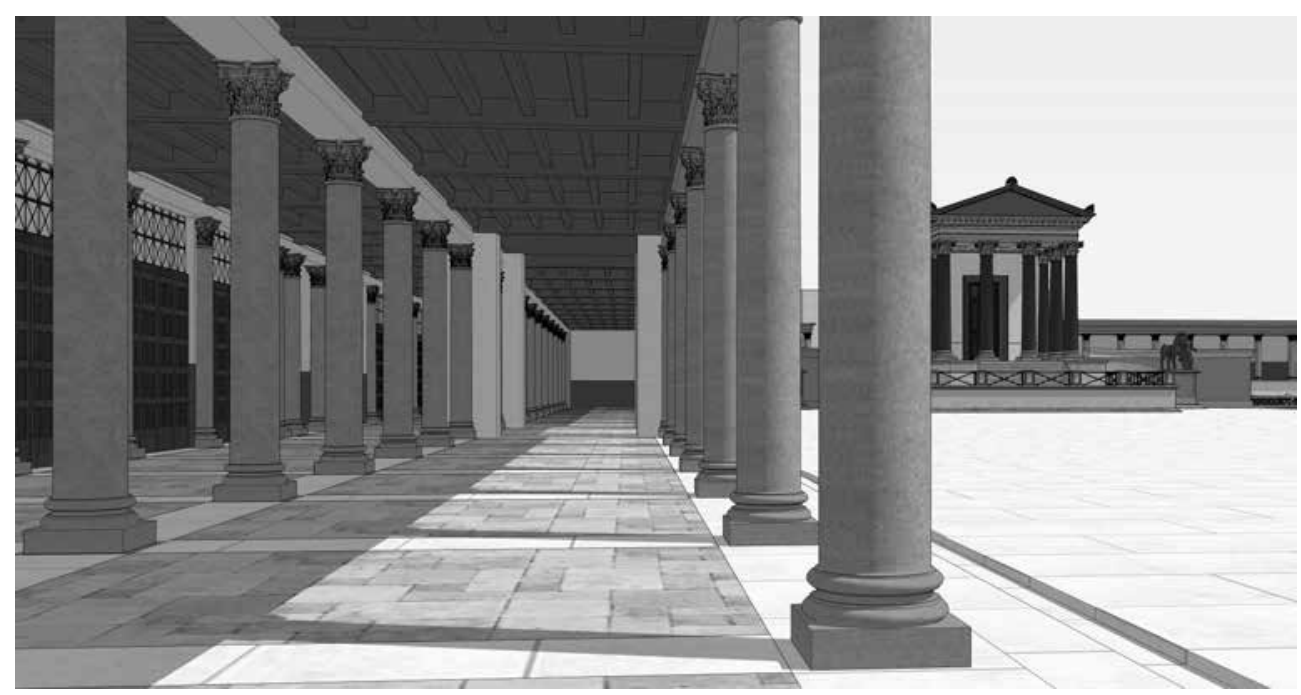

Fig. 3. Foro de Clunia, interior del pórtico comercial.

Ejemplo de este tipo de solución la podemos encontrar, en su manifestación formal, en Roma en el Foro de Cesar.

Podemos intuir que aquellos que diseñaron el foro de Clunia estaban pensando en la doble posibilidad. Un espacio que sirviera para el uso diario de la ciudad y que pudiera servir también como lugar de celebraciones de ferias, mercados y espectáculos relativos a la condición de Clunia como capital del Convento Jurídico, que obligaría a acercarse a ella a gentes de lejanas poblaciones con objeto de resolver asuntos administrativos y legales. La ciudad, por tanto, debería dar apoyo a estos visitantes con servicios especializados. Las últimas interpretaciones de los foros de Asturica Augusta ${ }^{3}$ y Caesaraugusta, capitales de los conventos jurídicos adyacentes al Cluniense, corroboran esta interpretación. El hecho de que ambos tres, respondan a un diseño cerrado, geométricamente claro y de grandes dimensiones, reafirma la idea de que fueron concebidos para esta función vinculada a la condición de capital administrativa, frente a otros conjuntos que se amplían o transforman a partir de un plano inicial a medida que surgen las necesidades.

Pero si el foro, en sus dimensiones y trazado responde a unos requerimientos que van mucho más allá de las necesidades de un municipio y su área de influencia, en el caso del teatro y de los edificios termales, esta característica se hace aún más patente si cabe. 


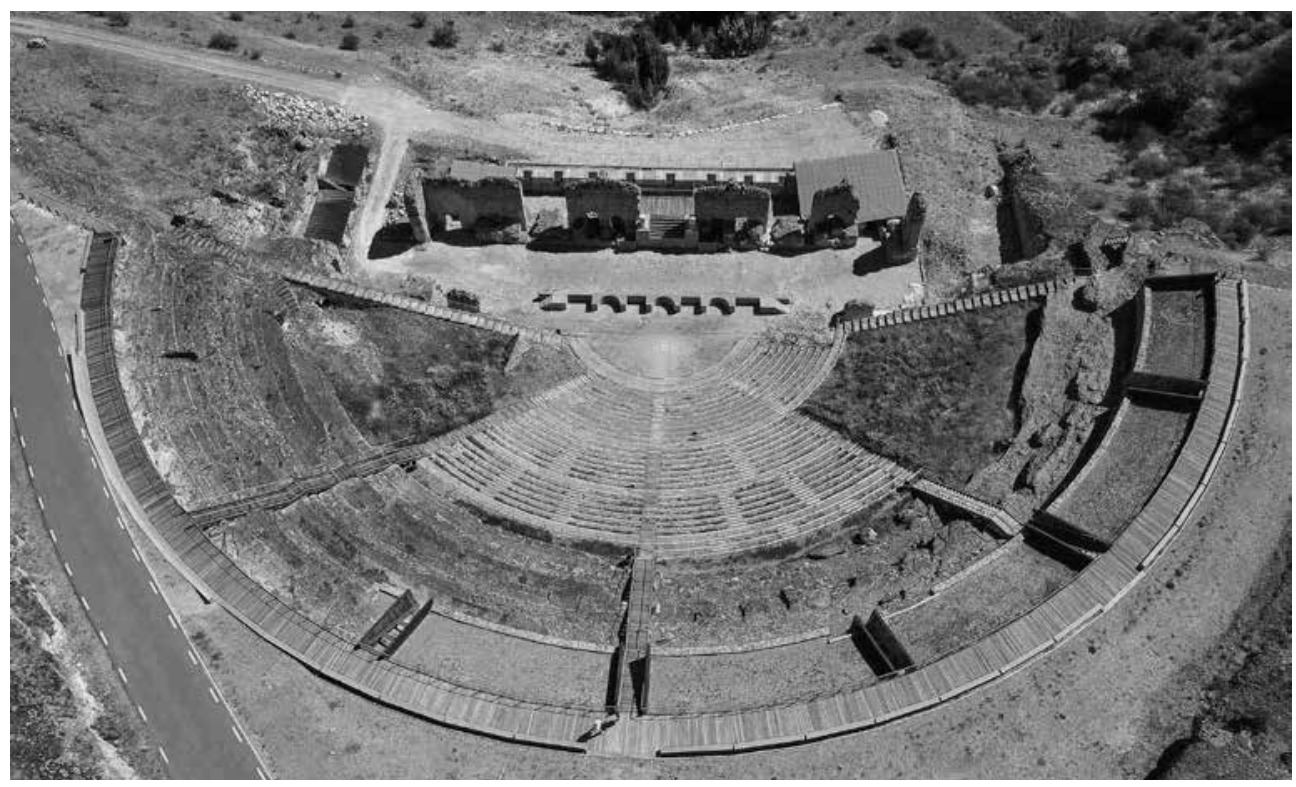

Fig. 4. Teatro Romano de Clunia. Vista aérea.

El Teatro presenta en su configuración, un monumental edificio de gran capacidad (entre 8.000 y 9.000 espectadores), realizado bajo un exquisito diseño arquitectónico ${ }^{4}$, con una calidad en su decoración arquitectónica superior a la realizada por los talleres locales y por lo que sabemos, a partir de los últimos trabajos de investigación, realizado con un sistema constructivo que implica una rápida ejecución.

Se localiza en el borde nororiental del Alto del Castro, ocupando así un espacio marginal en el entramado urbanístico de la ciudad. Es el vestigio arqueológico que ha llamado más la atención a viajeros, historiadores y arqueólogos debido a sus grandes dimensiones y a la espectacularidad de su graderío parcialmente tallado en la roca.

Las primeras excavaciones sistemáticas no se realizarán hasta los años 60 y 70 del pasado siglo con Pedro de Palol, quien sacará a la luz un teatro muy saqueado, del que apenas quedaba parte de la cavea y el núcleo de opus caementicium de sus diferentes estructuras. Sin embargo proporcionará una visión del edificio, en la que el cuerpo escénico se uniría al graderío en sus extremos a través de unas torres de planta rectangular, los parascaenium ${ }^{5}$. Así, graderío y cuerpo escénico conformarán una única unidad constructiva, en la que los parascaenium hacen de nexo de unión entre las dos partes constructivas, siendo un teatro acorde con el modelo que surge

\footnotetext{
${ }^{4}$ DE LA IGLESIA \& TUSET, 2010: 269-288.

${ }^{5}$ PALOL, 1994: 110.
} 


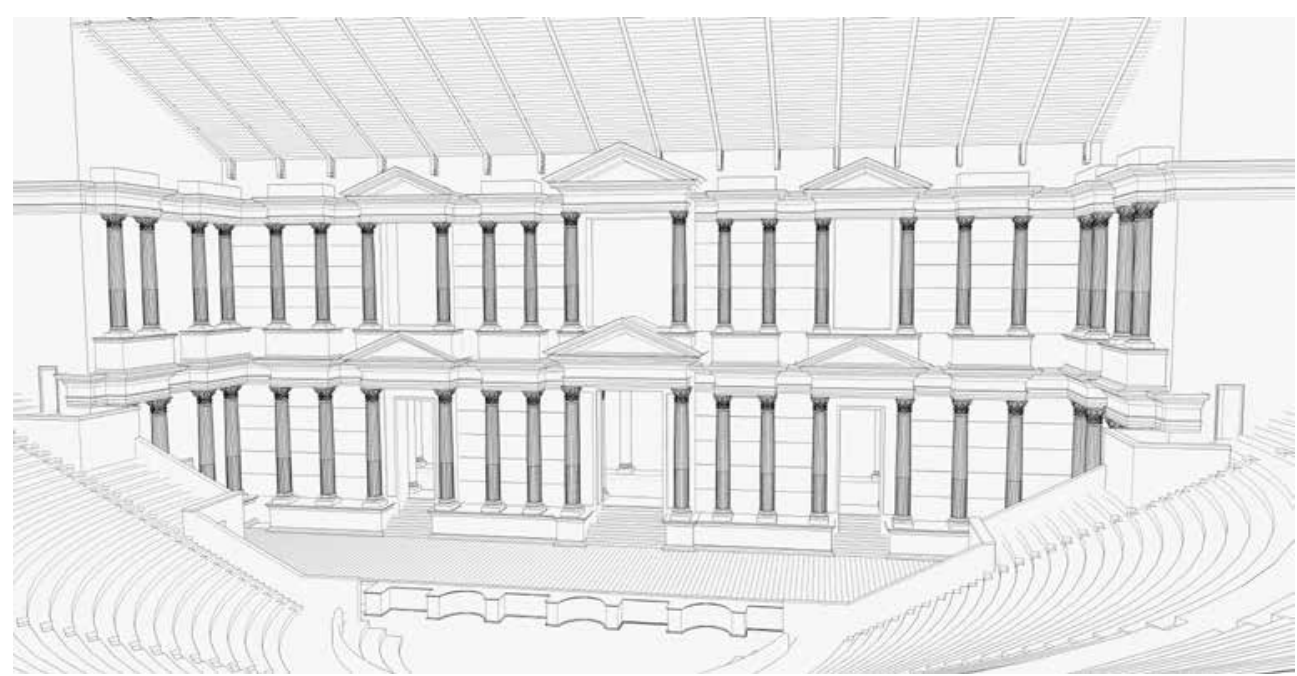

Fig. 5. Reconstrucción del Teatro de Clunia. Vista de la escena.

en época Augustea y Julio-Claudia ${ }^{6}$, a diferencia de los teatros anteriores, en los que graderío y cuerpo escénico no estaban unidos.

Las excavaciones arqueológicas llevadas a cabo en la década pasada han sacado a la luz un teatro similar al descrito por Pedro de Palol, construido durante el reinado de Domiciano ${ }^{7}$. Aunque en virtud de la superficie excavada se puede dar una mayor precisión en sus proporciones y dimensiones, alcanzando el diámetro máximo de la cavea los 102,9 metros. Su cavea, que estaría circundada por un porticus in summa gradatione, ya no aprovechará en su totalidad la orografía natural, si no que parte de ella, concretamente el sector meridional de la summa, se encontrará construida mediante un complejo de subestructuras masivas de opus caementicium. En el postscaenium existirá un gran espacio rectangular soterrado, el cual sería utilizado como espacio de almacenamiento. En cuanto a su scaenae frons, ésta a partir de los restos de decoración arquitectónica estaría organizada en dos órdenes superpuestos ${ }^{8}$.

Las termas públicas situadas en una misma zona de la ciudad, servidas por un gran pozo entre ellas, tienen unas dimensiones y diseño, único en la provincia. Los Arcos I presentan una disposición simétrica con recorridos diferenciados, hombres y mujeres, en los que se disponen los espacios para ejercicios, apoditerio, frigidario y tepidario, manteniendo un único caldario central, seguramente con uso alternativo con horarios diferentes. La exedra de acceso y un gran jardín donde seguramente se situaba una piscina, completan el conjunto. Los Arcos II se disponen de forma lineal

\footnotetext{
${ }^{6}$ MAR, 1994: 25-37.

${ }^{7}$ DE LA IGLESIA \& TUSET, 2010: 286.

${ }^{8}$ DE LA IGLESIA, 2016: 43-74.
} 
palestra, apoditerio con acceso a la letrina y por el extremo opuesto al itinerario termal; frigidario, tepidario, caldario y retorno hacia el frigidario desde el que se puede acceder a una sala de calor seco situada a continuación de su exedra.

Paralelamente a la presencia de estos dos conjuntos termales existen en Clunia pequeñas termas, como las denominadas Termas del foro que responden a una dimensión más adecuada para una ciudad de las dimensiones de Clunia, como si los habitantes habituales de la ciudad usaran estas pequeñas y solo se pusieran en funcionamiento las grandes en los momentos de afluencia a la ciudad de gente de todo el convento.

De todo este despliegue arquitectónico y monumental realizado en un breve período de tiempo se desprenden una serie de conclusiones que nos parece oportuno señalar:

Por un lado, a pesar de que, con toda seguridad, la decisión de situar en Clunia la capitalidad del Convento se realiza sobre la existencia de un municipio romano, los edificios a los que hemos hecho referencia son una consecuencia de esta decisión y se diseñan en su tipología y en sus dimensiones para servir a una población mucho mayor que la que habita en la ciudad y que acudirá a ella en determinados momentos. El foro, por ejemplo, dispone bajo el doble pórtico de mucho más espacio para la instalación de puestos de venta eventuales, del que se dispone para negocios permanentes en las tabernas. La sección escalonada que presenta esta solución permitiría disponer de unas terrazas lineales sobre el espacio central donde, seguramente, se podían instalar anfiteatros efímeros de madera como era lo habitual, en las ocasiones de afluencia de público, atraídos por la presencia del gobernador en la ciudad u otros eventos periódicos.

Las termas y el teatro en su concepción responden a esta misma situación de afluencia periódica, La instalación de dos grandes termas en un solo lugar, con división

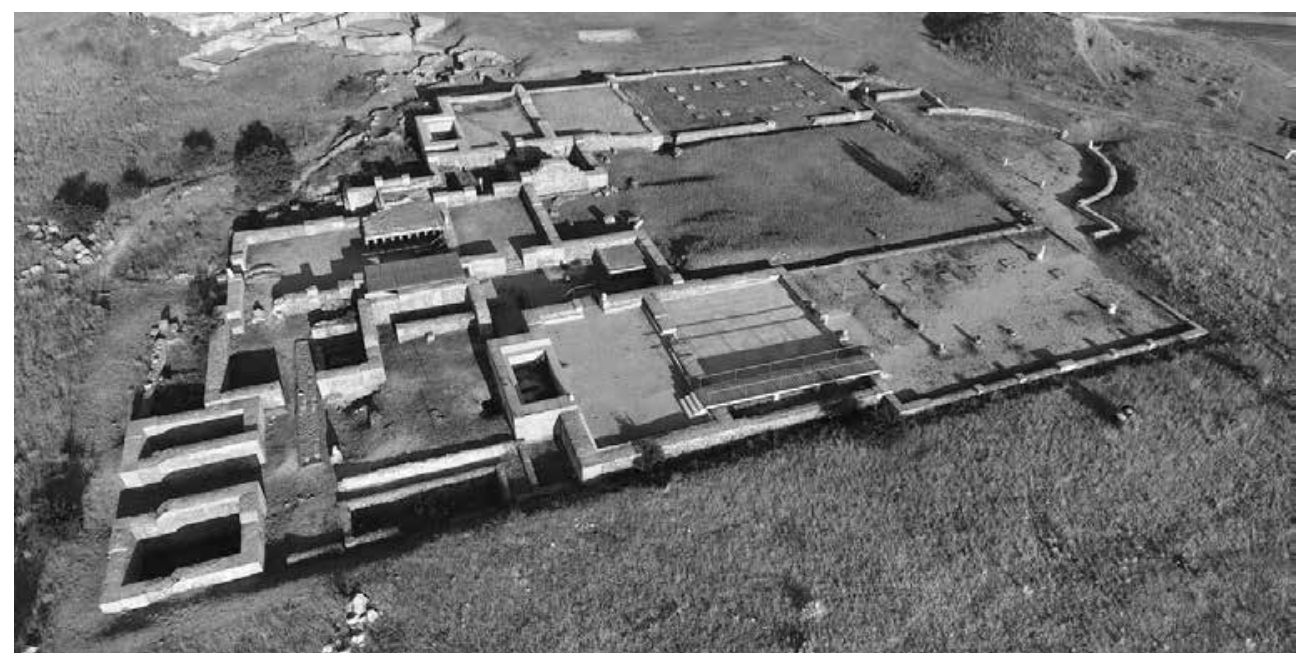

Fig. 6. Termas «Los Arcos I». Vista aérea. 


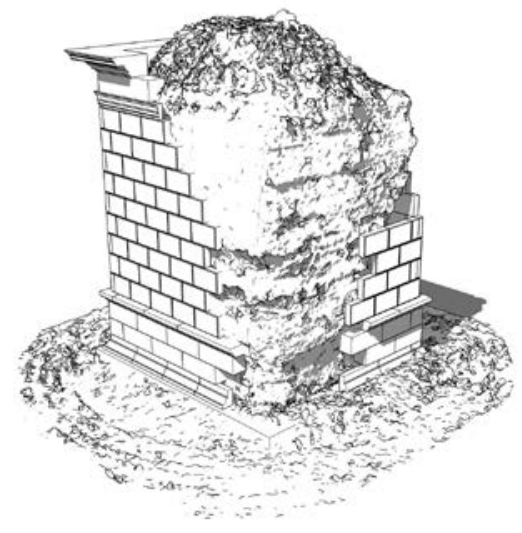

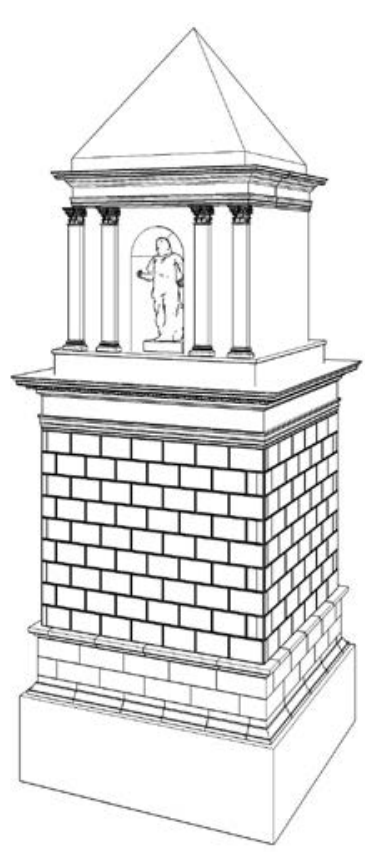

Fig. 7.

Monumento funerario «El Torreón».

Reconstrucción sobre los restos actuales.

de circuitos en el caso de la más grande y con unas dimensiones, muy por encima de lo común, o la gran capacidad del teatro, sólo se justifica desde esta hipótesis, ya que no parecen ser consecuencia de las necesidades de un municipio de las dimensiones de Clunia, que intenta de algún modo, convertirse en una urbe a imagen y semejanza de Roma, lo cual constituyó un indudable factor para la romanización del territorio.

En el mundo romano esta reproducción del modelo metropolitano, no solo se produjo en el ámbito urbano, sino también en la periferia urbana, concretamente en sus necrópolis, pues éstas se organizaban en torno a las vías de acceso a la ciudad. En ellas se adoptaron los modelos romanos, produciéndose un proceso de monumentalización y exteriorización de las tumbas. Este hecho que está constatado en otras ciudades, en Clunia debido al conocimiento parcial de su mundo funerario y la escasa atención que se ha prestado a la arquitectura funeraria monumental, apenas ha sido considerado.

Fuera de los límites de la ciudad, en la ladera meridional del Alto del Castro, sobre una plataforma intermedia situada entre el cerro y el fondo del valle del río Arandilla, se halla El Torreón, una estructura prismática, realizada en opus caementicium, de más de ocho metros de altura. Se halla en las inmediaciones de Cuevas Ciegas, uno de los accesos históricos al yacimiento9 ${ }^{9}$. Esta ubicación, junto con sus notables dimensiones, le confiere unas condiciones privilegiadas de visibilidad.

\footnotetext{
${ }^{9}$ CAMACHO VÉLEZ, 2014: 12.
} 
Presenta una planta rectangular de 4,86 metros de longitud en su lado corto y de 5,45 metros en el largo. Tres de sus caras, la Norte, Este y Sur son planas, si bien presentan tenues de improntas de un paramento de sillería, hoy desaparecido, que actúo de cajón o encofrado permanente del núcleo de caementicium. Por el contrario su cara occidental es convexa y está erosionada. Este hecho se justificaría por la presencia de un cuerpo superior con forma de aedicula, hoy desaparecido, que en su fachada principal presentaba un nicho abierto al exterior ${ }^{10}$.

De esta manera nos encontramos ante un monumento turriforme que constaba de un podium y dos pisos o cuerpos superpuestos desarrollados en altura. Su piso superior, el que se correspondería con la aedicula, presentaría en su fachada principal un nicho abierto al exterior que albergaría la representación del difunto. Siendo la fachada principal la cara occidental del monumento, que estaría orientada una la vía de acceso a la ciudad.

Este monumento no fue un elemento aislado en el territorio. La fotografía aérea nos ha mostrado la existencia de una vía de acceso a la ciudad, en las cercanías de El Torreón. Ésta se encuentra flanqueada por recintos cuadrangulares, cuyo tamaño oscila entre los 30 y 50 metros de lado. Varios de estos recintos, al menos seis, presentan en su interior otras estructuras cuadrangulares de menor tamaño. Estas evidencias se han interpretado como recintos con monumentos funerarios en su interior que se encontraban jalonando la citada vía ${ }^{11}$.

El análisis de los epígrafes y la decoración arquitectónica, aparecida en Clunia y sus alrededores, apuntan a la pertenencia de algunos de estos elementos a monumentos funerarios que se hallarían en las distintas necrópolis de la ciudad. Es particular caso de la Ermita del Santo Cristo de San Sebastián de Coruña del Conde, la cual cuenta con notable material arquitectónico pertenecientes a varios monumentos funerarios de carácter arquitectónico ${ }^{12}$.

\section{¿FRACASO O ADAPTACIÓN?}

Todos estos notables edificios, así como los espacios urbanos construidos en Clunia servían para actividades que no se desarrollaban de forma continuada en el tiempo y en muchos de ellos, su utilización óptima sólo se realizaba en momentos concretos de aumento de la población, quedando desangeladas el resto del año,

\footnotetext{
${ }^{10}$ Este mismo fenómeno se puede observar en la torre del Cincho (RODRÍGUEZ HIDALGO, 1979: 425-432), así como algunas piles funerarias de la Aquitania (SOUKIASSIAN, 2006: 473-477). Éstos son monumentos turriformes caracterizados por tener un cuerpo superior en forma de aedicula, la cual en su fachada principal presentan un nicho abierto al exterior. En la actualidad se puede observar como cuando la aedicula por diferentes razones ha perdido su cubrimiento, bajo ésta, la superficie de la fachada principal se encuentra notablemente erosionada y alterada, al recoger el nicho el agua procedente de las precipitaciones y llevarlo hacía la fachada del piso inferior

${ }^{11}$ OLMO MARTÍN, 2001: 8.

${ }^{12}$ ABASCAL PALAZON, 2015: 223-224.
} 
necesitados de un mantenimiento, mucho mayor que el propio de un municipio, y que seguramente suponía una carga que la ciudad no pudo soportar.

Es evidente que existe una clara intención propagandística en toda la operación arquitectónica, una clara demostración por parte de Roma de superioridad a partir del dominio de la técnica de la sofisticación de sus propuestas y de la manifestación, en definitiva de una idea de civilización superior. Pero da la impresión, al menos en el caso de Clunia, que los cálculos no se hicieron adecuadamente, que las expectativas no se cumplieron o simplemente que las poblaciones que dependían, y por tanto debían acudir a Clunia, lo hacían sólo por razones administrativas, acercándose a Caesaraugusta para las cuestiones comerciales, seguramente porque era más cómodo y, por qué no decirlo, más lógico y natural desplazarse siguiendo la cuenca del Ebro, como parece confirmar la nueva organización provincial en el Bajo Imperio. Por otra parte el hecho de que los clunienses aceptaran formar parte del sistema administrativo romano, no significa necesariamente que se sintieran igual de identificados con la arquitectura y el uso de la misma que Roma les había impuesto, y es probable que mantuvieran costumbres, actividades y sistemas de convivencia que no se adaptaban del todo al nuevo diseño de la ciudad. Por lo que sabemos a partir del siglo II la vida en la ciudad no se desarrolla como estaba previsto.

Así, por ejemplo, en la segunda mitad del siglo II. d. C. el Teatro sufre una notable reforma para desarrollar en él espectáculos propios de un anfiteatro, munera y venationes. Para ello se creará un gran espacio a modo de arena, mediante la ampliación de la orchestra. La proedria será desmontada, así como las gradas más bajas de la ima cavea, hasta llegar las puertas de los aditi, coincidiendo con una estructura semicircular de contención de los niveles sobre los que se construye las gradas y de captación de aguas proveniente de manantiales. Dada la pendiente general del graderío, esta demolición es suficiente para obtener un desnivel necesario para la generación del podium del nuevo uso. El frons pulpiti también será eliminado, así como el pulpitum, consiguiendo de esta manera gran ámbito, de $2.554 \mathrm{~m}^{2}$, que será cubierto por un nivel de tierra batida a modo de suelo continuo.

Esta transformación generó una gran cantidad de escombros y restos constructivos, que fueron depositados en el hypopostscaenium, siendo éste amortizado en su totalidad ${ }^{13}$.

En el sector central de esta nueva arena, se colocó un gran sillar de caliza (70x71x40 centímetros), cuya cara superior presenta un rebaje circular en el que se instalaría una argolla de unos 30 centímetros de diámetro ${ }^{14}$. Flanqueando el rebaje de la argolla, esta pieza presenta una inscripción epigráfica organizada en cuatro líneas, una en cada uno de sus lados, con el texto en capital cuadrada alargada:

\footnotetext{
${ }^{13}$ DE LA IGLESIA \& TUSET, 2010: 271.

${ }^{14}$ GUTIÉRREZ et al., 2006: 303.
} 


\title{
SENECIONE E APOLINARE
}

\section{COS}

\author{
G $\cdot$ TAVTIVS
}

SEMANVS

AEDIL · N P MF

Senecione e(t) Apol(l)inare / co(n)s(ulibus) // G(aius) Tautius // Semanus // aedil(is) $n$ (ovum) p(ecunia) $m$ (ea) $f(e c i)$

Que podría traducirse: Bajo el consulado de Senecio y Apolinar, el aedil Gaio Tautio Semano lo reedificó con dinero.

Esta pieza tendría una doble finalidad, la de conmemorar la transformación del edificio, señalando quién y cuándo se realiza, concretamente en el 169 d. C., año en que Q. Sosius Priscus Senecio y P. Caelius Apollinar son cónsules. Así como la de sujetar animales durante la celebración de venationes.

Piezas similares a ésta, pero sin epígrafe, se han hallado en el anfiteatro de Contributa Iulia Ugultunia en Lusitania ${ }^{15}$ y en el centro de la arena del de Deva Victrix en Britannia ${ }^{16}$. Así como una representación iconográfica en el mosaico gladiatorio de la villa romana de Bignor también en Britannia, donde una pareja de gladiadores luchan en torno a un bloque con una argolla en su parte superior ${ }^{17}$.

Las transformaciones no solo se produjeron en el ámbito de la arena, si no también fuera de los límites de ésta. Así en el extremo meridional del área que ocuparía el pulpitum, se ha constatado la presencia de un sacellum, realizado con adobes y columnas de fuste liso reutilizadas.

Esta transformación para albergar munera y venationes, se encuadra en un proceso, que desde finales del siglo I d. C. y principios del II, con el teatro de Iol/ Cherchel como ejemplo más temprano en el tiempo ${ }^{18}$, hasta ya avanzado el siglo III, se produce en una serie de ciudades del Imperio, que renovarán y transformarán sus edificios escénicos con la finalidad de albergar en ellos espectáculos gladiatorios, los cuales gozaban ya de mayor popularidad que los ludi scaenaci. De esta manera el hecho de que la tradición constructiva de los teatros fuera anterior a la del anfiteatro ${ }^{19}$, provocó que estas ciudades, que contaban con un teatro construido y deseaban tener un edificio estable destinado a juegos gladiatorios, optasen por transformar su edificio escénico en una arena. Optando por una opción más práctica y económica que la construcción de un nuevo edificio.

\footnotetext{
${ }^{15}$ PIZZO et al., 2016: 262.

${ }^{16}$ WILMOTT, 2008: 143.

${ }^{17}$ WILMOTT, 2008: 142; láms. 22 y 26.

${ }^{18}$ GOLVIN \& LEVEAU, 1979: 841.

${ }^{19}$ BENDALA GALÁN \& DURÁN CABELLO, 1994: 259.
} 
En Las Termas Los Arcos I el apoditerio NO aparece compartimentado en habitaciones por encima del mosaico con niveles de abandono en época de Teodosio ${ }^{20}$. Palol apunta que el edificio siguió utilizándose después de la crisis del siglo III pero con una función distinta a la de baños, habitación y acaso como zona de talleres de TSHT, dada la presencia de fragmentos de moldes pero no precisa el momento en que pierde su función termal. De los diarios de excavación y de los materiales, cerámicas y monedas, parece desprenderse que, con anterioridad a esta transformación se había producido una reducción de los espacios dedicados a baños, limitándose estos al apoditerio, frigidario y tepidario del cuerpo S. que se divide por su mitad y se emplaza en su lado E un caldario. Otro tanto puede decirse del saqueo del pórtico y enlosado del decumano que separa Los Arcos I y II, en donde, tras el saqueo, se regulariza el suelo con aportaciones de tierra entre la que sólo aparece TSH alto imperial. Cabría pensar si las monedas de tiempos de los Antoninos a que alude Palol para fechar la gran reforma del edificio no son, en realidad, los últimos testimonios de la utilización del edificio como terma, dado que se encontraron por encima de los pavimentos ${ }^{21}$.

Las Termas denominadas Los Arcos II presenta una situación similar. Las letrinas se desmontan y se llenan de escombros cegando la alcantarilla de desagüe del frigidario $\mathrm{y}$, posiblemente, del resto del edificio inutilizándolo como terma en un momento que, difícilmente, puede llevarse a principios del siglo $\mathrm{II}^{22}$. La actividad en el edificio continúa, precedida de un intenso saqueo; del banco de las letrinas, las cubiertas de las alcantarillas que transcurren bajo los mosaicos del apoditerio y frigidario, de los ladrillos de los hipocaustos y de las tejas de las que se encontró un gran depósito en el exterior de la exedra del caldario. Tras el saqueo se documenta una escalonada acumulación de escombros por habitaciones que finaliza en la segunda mitad del s. III con el hundimiento de un tejado en la palestra con monedas de Claudio II y sin constatarse, en ningún momento, materiales del siglo IV o $\mathrm{V}$ en este edificio.

En el conjunto del foro algunos aspectos permiten suponer cambios trascendentales a lo largo de los siglos II-III. Numerosas pruebas arqueológicas hacen suponer que la actividad en el conjunto de las tabernas del foro ha decaído de forma manifiesta a lo largo del siglo III y la basílica parece frecuentarse con un uso incierto, hasta fines del siglo IV ${ }^{23}$.

En la Casa 1 o Casa Taracena ${ }^{24}$, las sucesivas reformas parecen alargar su utilización hasta el siglo IV pero resulta interesante señalar que en las últimas excavaciones, 20052006, no concluidas y en fase de estudio, se ha podido constatar en la esquina de la

\footnotetext{
${ }^{20}$ PALOL, 1994: 92.

${ }^{21}$ PALOL, 1994: 91.

${ }^{22}$ PALOL, 1994: 93-99.

${ }^{23}$ DE LA IGLESIA \& TUSET, 2013: 108-109.

${ }^{24}$ PALOL, 1994: 46-48.
} 
casa que da fachada con la basílica, la amortización de las habitaciones subterráneas con escombros y sobre estos e invadiendo cardo y decumano se extiende, con abundantes restos de TSHT, un gran vertedero.

A este panorama se le puede añadir el enmudecimiento de la epigrafía con no más de dos o tres fragmentos de epígrafes para los que podría aceptarse una cronología del siglo III, pero que, en contrapartida, nos ofrece la tabula patronatus de la Biblioteca Apostólica Vaticana fechada en el 222 d. $C^{25}$.

A modo de resumen puede pensarse que la ciudad a partir del siglo II, por causas que se nos escapan, inicia un drástico proceso de transformación que parece buscar, como apuntábamos al principio, una adaptación a una nueva situación, desligada de fastos e intereses imperiales y sin duda más preocupada de pervivir, contando solamente con sus posibilidades y respondiendo a sus propios intereses. Pensamos que estos cambios deben entenderse como una reconversión, que a juzgar por la circulación monetaria y cerámica, hasta el siglo $\mathrm{V}$, fue un éxito y, entre otras cosas, se hizo a costa del urbanismo, la arquitectura y las estructuras domésticas de la ciudad del siglo I.

Clunia a pesar de su temprana cristianización, como demuestra la necrópolis alrededor de la Ermita de Castro, no consigue ser sede episcopal, como ocurrió con el resto de capitales conventuales, pero algún papel siguió desempeñando en el territorio del antiguo convento, acaso redefinido y dimensionado de una forma más acorde con los nuevos tiempos. A partir del siglo VI las fuentes históricas y arqueológicas no nos dicen nada de la ciudad y de su papel en la administración del territorio que debió seguir capitalizando como lo está haciendo en el momento de la llegada de Castilla al Duero ${ }^{26}$.

\section{LA INTERVENCIÓN ARQUITECTÓNICA COMO MÉTODO DE DIFUSIÓN DEL CONOCIMIENTO DE LA CIUDAD, TIERMES}

En las largas campañas de las Guerras Celtibéricas, Roma envió durante años y sin éxito, a su poderoso ejército contra los arévacos, los más guerreros entre los celtíberos, cuyas ciudades, sobre todo Numancia y Tiermes, fueron durante décadas inexpugnables. La naturaleza del estrato rocoso que sirve de base a Tiermes (blandas areniscas rojas) posibilitó que, ya en época celtibérica, se empleara ésta para instalar viviendas rupestres o semirrupestres adaptadas al duro clima soriano, que se han conservado intactas junto a otras edificaciones romanas realizadas con muros de sillería y/o mampostería. Al periodo de ocupación romana corresponden la mayor

\footnotetext{
${ }^{25}$ PALOL \& VILELLA, 1987: 91.

${ }^{26}$ En ese sentido nos resulta esclarecedora e ilustrativa la comunicación de Ma Pia Senent Díez, en la que se remarca la presencia documental de Clunia en los siglos IX y X, junto a las demás sedes episcopales y con un trato equivalente, se la incluye entre las civitas y desde ella el merino administra el alfoz cluniense (SENENT, 2010: 155-166).
} 
parte de los vestigios arqueológicos visitables: la Casa del Acueducto, el Graderío y el Acueducto tallados en la roca, la Muralla Bajoimperial, el Foro, etc.

En la actualidad el paisaje de Tiermes es el resultado de la acumulación de acciones antrópicas, reflejo del paso de diferentes culturas y momentos de actividad que dan como resultado un mágico territorio de difícil comprensión, lleno de preguntas sin respuesta.

En 2007 la Dirección General de Patrimonio Cultural de la Junta de Castilla y León decidió acometer los trabajos en Tiermes desde una filosofía innovadora, integrando disciplinas en la concepción de un nuevo modelo metodológico de intervención en el patrimonio arqueológico denominado TIERMES LABORATORIO CULTURAL. De este modo, el conjunto de intervenciones realizadas en Tiermes va más allá de la mera consolidación y puesta en valor de una serie de estructuras de interés y plantea una perfecta inserción del conjunto en el propio paisaje del yacimiento. Para ello se estableció un equipo formado por tres grupos, el Laboratorio para la Investigación e Intervención en el Paisaje Arquitectónico, Patrimonial y Cultural de la Universidad de Valladolid, la Unidad de Arqueología de la IE Universidad y los Servicios Central y Territorial de Soria de la Consejería de Cultura de la Junta de castilla y León ${ }^{27}$.

Uno de los conceptos más novedosos que proponía desarrollar Tiermes Laboratorio Cultural es el de entender que el yacimiento configura, en su totalidad, un paisaje cultural que contiene multitud de valores y que permite una variedad muy amplia de lecturas y comprensiones. Desde la rica topografía, la diversidad paisajística, la naturaleza del terreno, las formas vegetales, los elementos arquitectónicos, los

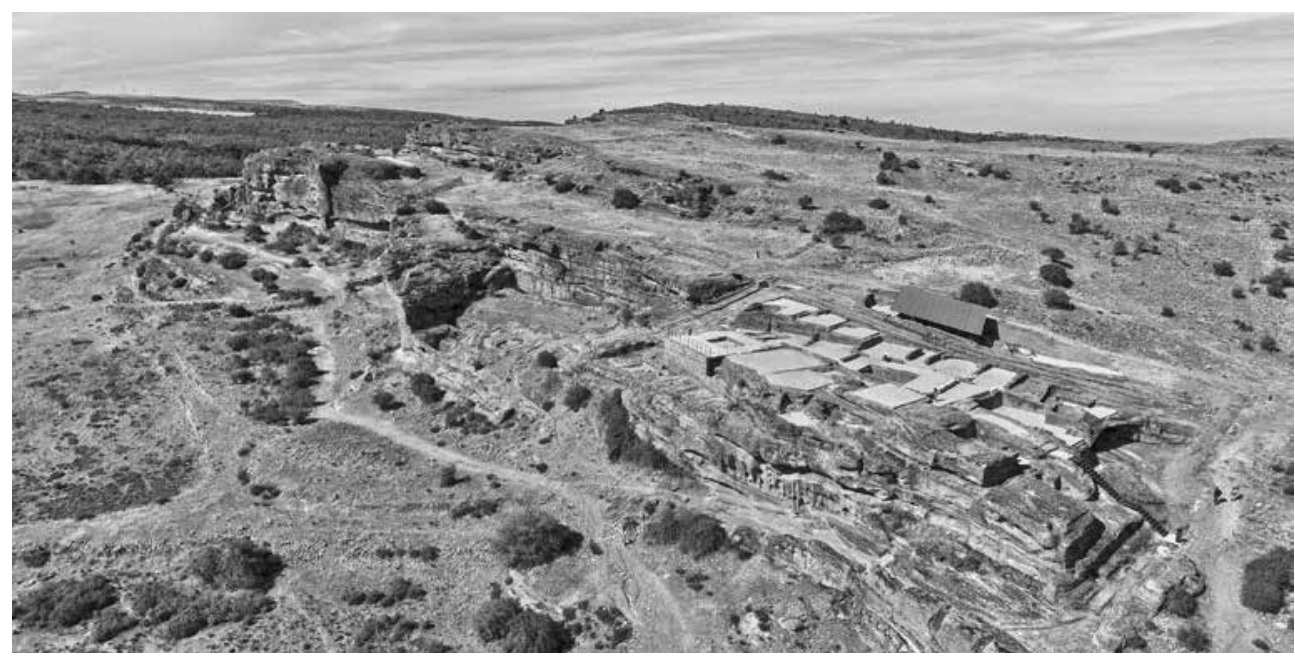

Fig. 8. Tiermes, La huella de la ciudad sobre la roca. Vista de la vertiente sur.

${ }^{27}$ DE LA IGLESIA, 2009: 35-48. 
restos arqueológicos, etc. todos los sistemas configuran y aportan una idea de paisaje al completo, y se hace necesario que el visitante la perciba como tal en su recorrido por el yacimiento.

De los estudios en curso, se deduce que la ciudad romana de Tiermes, fue una ocupación de un cerro ya antropizado en época celtibérica, pero configurando una ciudad netamente romana, construyendo edificios que apoyados sobre la roca emergente tenían el aspecto y funcionalidad de cualquier ciudad de su momento y respondiendo a modelos conocidos. El hecho de que los restos que han llegado a nuestros días sean los cortes en la roca, habitaciones excavadas, y plataformas, no quiere decir que se trate de una arquitectura rupestre, como a veces encontramos en la literatura sobre el yacimiento, ni que sus habitantes vivieran en casas excavadas en la montaña, tipo cuevas, eremitorios o galerías, propias de organizaciones propiamente rupestres. Se trata simplemente de los restos de una ciudad saqueada que por estar acomodada en un alto rocoso de fácil labra ha regularizado el encuentro de su arquitectura con la montaña y al desaparecer el porcentaje mayor de sus construcciones, restan solamente los cortes y habitaciones marginales de sus edificios, marcados sobre la montaña. Cualquier ciudad dispuesta del mismo modo mostraría las mismas huellas una vez eliminados todos los materiales constructivos aportados para su edificación. La Domus Áurea o el Palatino en Roma si fueran despojados de los últimos restos de su construcción, presentarían oquedades habitaciones excavadas en horizontal $y$ vertical, y nada indica a pensar que los emperadores habitaban una arquitectura rupestre. La desproporción entre lo construido frente a lo tallado en la montaña, al igual que en Tiermes, inclina su consideración hacia lo que es, una arquitectura en positivo.

En el caso del Foro de la ciudad, este aspecto resulta mas evidente, apoyado sobre una ladera, establece una gran plataforma con rellenos y subestructuras importantes, resultando un complejo edificio con acceso en dos niveles diferentes.

Los trabajos destinados a la recuperación del Foro pretenden cubrir dos aspectos bien diferenciados, por un lado su conservación y por otro su comprensión, habida cuenta que el saqueo producido en los siglos anteriores había desdibujado su arquitectura, se trataba de hacer entender la magnitud de su arquitectura y las características de su implantación, pues si bien desde la arqueología podemos documentar la presencia de la acción material, desde el proyecto de arquitectura se establecen los mecanismos para conocer la ausencia de material, que es precisamente lo que nos permite reconocer la arquitectura que estamos tratando de entender y por ende la ciudad completa.

Como continuación de la obra de recuperación del Foro, se acometieron toda una serie de actuaciones necesarias para continuar la visita al Yacimiento Arqueológico en su parte suroeste. La intervención desarrolla la recuperación, protección y puesta 
en valor del Conjunto Rupestre del Foro y la Casa del Acueducto y por otro plantea una nueva estrategia en la comprensión del yacimiento, basada en la creación de sistemas de recorridos en forma de clusters (racimos) que permitan una articulación flexible y amplia de las visitas ${ }^{28}$.

De esta forma se pretendía que el visitante sea consciente de que contempla los restos de una ciudad, con una estructura importante, que conserva elementos singulares aunque disgregados en el paisaje y que para comprender lo que ve, tiene de algún modo que reconocer lo que falta. Con esto se quiere atenuar el sentido romántico que acompaña la visita de Tiermes y al que parecen supeditarse los restos arqueológicos. Es cierto que la roca tiene una poderosa presencia, pero no es menos cierto que gran parte fue tallada en su momento para apoyar viviendas, calles y otras estructuras y que por lo tanto la belleza formal que hoy presenta se debe fundamentalmente a la acción humana. Este es uno de los argumentos, por ejemplo, de la recuperación de la Casa del Acueducto, que se muestra al visitante como un importante tipo arquitectónico, con todos sus elementos domésticos, asomado a la cornisa sur de la roca.

En definitiva, ya sea en Clunia o en Tiermes, acercarnos al paisaje arqueológico, desde la emoción no elimina en absoluto la capacidad de la memoria fijada a través del tiempo, sino que la intensifica y nos invita a establecer los mecanismos necesarios para su mejor comprensión y conocimiento.

\section{BIBLIOGRAFÍA}

ABASCAL PALAZÓN, Juan Manuel (2015) - La ermita del Santo Cristo de San Sebastián (Coruña del Conde, Burgos) y sus monumentos de época romana. "Archivo Español de Arqueología», 88, p. 223-246.

BENDALA GALÁN, Manuel; DURÁN CABELLO, Rosalía-María (1994) - El anfiteatro de Augusta Emerita: rasgos arquitectónicos y problemática urbanística y cronología. In ÁLVAREZ MARTÍNEZ, José María; ENRIQUEZ NAVASCUÉS, Juan Javier, coords. - El anfiteatro en la Hispania romana. Actas del coloquio internacional celebrado en Mérida los días 26 al 28 de Noviembre de 1992. Badajoz: Junta de Extremadura, p. 247-264.

CAMACHO VÉLEZ, Gustavo (2014) - Clunia: una perspectiva arqueológica. «Clio: History and History Teaching», 40.

DE LA IGLESIA, Miguel Ángel (2009) - Trabajos de consolidación y restauración en el Yacimiento Arqueológico de Tiermes. «Opidum», 4, p. 35-48.

(2015) - Paisaje Arqueológico y Laboratorio Cultural. In FRANCIOSINI, Luigi; CASADEI, Cristina, eds. - Architettura e Patrimonio: progettare in un paese antico. Roma: Mancosu Editore, p. 69-80. (2016) - El Teatro Romano de Clunia. De la Investigación a la Restauración. In NOGUERA GIMÉNEZ, Juan Francisco; SONGEL GONZÁLEZ, Juan María; NAVALÓN MARTÍNEZ, Virgina, eds. - Teatros romanos de Hispania: conservación, restauración y puesta en valor. Valencia: Editorial UPV, p. 43-74.

DE LA IGLESIA, Miguel Ángel; TUSET, Francesc (2010) - La restitución de la scaenae frons del teatro de Clunia. In RAMALLO ASENSIO, S. F. y RÖRING, N. eds. - La scaenae frons en la arquitectura

\footnotetext{
${ }^{28}$ DE LA IGLESIA, 2015: 68-80.
} 
teatral romana. Actas symposium internacional celebrado en Cartagena en marzo de 2009. Murcia: Universidad de Murcia, p. 269-287.

(2013) - El proyecto del Foro de Clunia. Espacio y función. In SOLER HUERTAS, Begoña; MATEOS CRUZ, Pedro, NOGUERA CELDRÁN, José Miguel; RUIZ DE ARBULO BAYONA, Joaquín, eds. - Las sedes de los ordines decvrionvm en Hispania. Análisis arquitectónico y modelo tipológico. Mérida: Consejo Superior de Investigaciones Científicas, p. 97-110.

GOLVIN, Jean Pierre; LEVEAU, Philippe (1979) - Lamphithéâtre et le théâtre-amphithéâtre de Cherchel: monuments à spectacle et histoire urbaine à Caesarea de Maurétanie. «Mélanges de l'Ecole française de Rome. Antiquité», tome 91, n. ${ }^{\circ}$ 2, p. 817-843.

GUTIÉRREZ BEHEMERID, María Ángeles; DE LA IGLESIA, Miguel Ángel; TUSET, Francesc; SUBÍAS, Eva (2006) - El teatro de Clunia: nuevas aportaciones. In MÁRQUEZ, Carlos; VENTURA, Ángel, eds. - Teatros romanos en Hispania. Actas del congreso internacional celebrado en Córdoba los días 12 al 15 de noviembre de 2002. Córdoba: GrafiSur, p. 291-310.

MAR, R. (1994) - Vitrubio y la tipología de los teatros augústeos. Un problema de interpretación histórica. «Braçal. Revista del Centre d'Estudis del Camp de Morvedre», 10, p. 23-44.

OLMO MARTÍN, Julio del (2001) - Arqueología aérea en Clunia. «Revista de Arqueología», vol. 22, n. ${ }^{\circ} 244$, p. 6-9.

PALOL, Pedro de (1994) - Clunia: historia de la ciudad y guía de las Excavaciones. Burgos: Diputación Provincial de Burgos/Junta de Castilla y León.

(2001) - El teatro romano de Clunia. In PALOL, Pedro de et al. - Clunia 0: studia varia cluniensia. Burgos: Diputación Provincial de Burgos, p. 325-339.

PALOL, Pedro de; GUITART, Josep (2000) - Los Grandes conjuntos públicos. El foro colonial de Clunia. Burgos: Diputación Provincial de Burgos. (Clunia VIII.1).

PALOL, Pedro de; VILELLA, José (1987) - Clunia II: la epigrafia de Clunia. Madrid: Ministerio de Cultura, Dirección General de Bellas Artes y Archivos, Subdireccion General de Arqueologia y Etnografia.

PIZZO, Antonio; MATEOS, Pedro; MAYORAL, Victorino (2016) - El anfiteatro de Contributa Iulia Ugultunia. Identificación y primer análisis arqueológico. Archivo Español de Arqueología, 89, p. 249-271.

RODRÍGUEZ HIDALGO, J.osé Manuel (1979) - Anotaciones en torno a Basilippo: la Torre del Cincho, «Habis», 10, p. 425-435.

SENENT, María Pía (2010) - Comunidades campesinas y poblamiento del Duero oriental durante la Edad media. In BURÓN ÁLVAREZ, Milagros, coord. - Patrimonio Cultural y Territorio en el Valle del Duero. Zamora: Junta de Castilla y León, p. 155-166.

SEVILlANO, M. A. (2005) - El Forum de Asturica Augusta. Astorga: Ayuntamiento de Astorga.

SOUKIASSIAN, Georges (2006) - Les Piles funéraires du Sud-Ouest. In MORETTI, Jean-Charles; TARDY, Dominique, eds. - L'architecture funéraire monumentale: la Gaule dans l'empire romain. Actes du colloque organisé par l'IRRA du CNRS et le musée archéologique Henri-Prades (Lattes, 11-13 octobre 2001), p. 473-477.

WILMOTT, T. (2008) - The roman amphitheatre in Britain. Stroud, Tempus. 


\section{REFLEXÕES EM TORNO DO CUSTO \\ DA MONUMENTALIZAÇÃO DO ESPAÇO \\ URBANO DE BRACARA AUGUSTA. \\ O CASO DO TEATRO: PRODUÇÃO \\ E CUSTO DO PROGRAMA DECORATIVO \\ DA FRONS SCAENAE*}

JORGE RIBEIRO**

MANUELA MARTINS***

\section{O TEATRO DE BRACARA AUGUSTA: CONTEXTUALIZAÇÃO E SIGNIFICADO URBANÍSTICO}

O teatro de Bracara Augusta foi construído nos inícios do século II, tendo ocupado o limite da plataforma superior da cidade, onde assentava o forum (Fig. 1) ${ }^{1}$. Estas obras, em conjunto com umas pequenas termas públicas, tiveram um impacto considerável numa cidade da dimensão de Bracara Augusta, provocando alterações no traçado das ruas, mexendo com quatro insulae e transformando globalmente a paisagem urbana. Em termos de perspetiva, presumimos que o muro do post scaenam deve ter implicado uma modificação notável da vista da cidade pelo lado oeste ${ }^{2}$, enquanto a área envolvente do foro e os acessos à praça pública, pelo lado poente, ficaram condicionados pelo impacto dos novos edifícios públicos. Presumimos que a localização do teatro terá sido escolhida de modo a estabelecer uma relação axial ente este e o forum, associada à relação processional que deveria existir entre estes dois espaços ${ }^{3}$. Aliás, são visíveis, a nascente do muro perimetral do teatro, vestígios

\footnotetext{
* Este trabalho teve o apoio financeiro do Projeto UID/AUR/04509 e da FCT-MEC através de fundos nacionais e quando aplicável do cofinanciamento do FEDER, no âmbito do novo acordo de parceria PT2020.

** Bolseiro de pós-doutoramento da FCT (SFRH/BPD/79511/2011), LAB2PT, UMinho. joribeiro@portugalmail.pt.

*** UAUM, LAB2PT, UMinho. mmmartins@uaum.uminho.pt.

${ }^{1}$ MARTINS et al., 2006; MARTINS et al., 2013; MARTINS et al., 2015.

${ }^{2}$ RIBEIRO, 2013: 457.

${ }^{3}$ MARTINS et al., 2015: 166-167.
} 


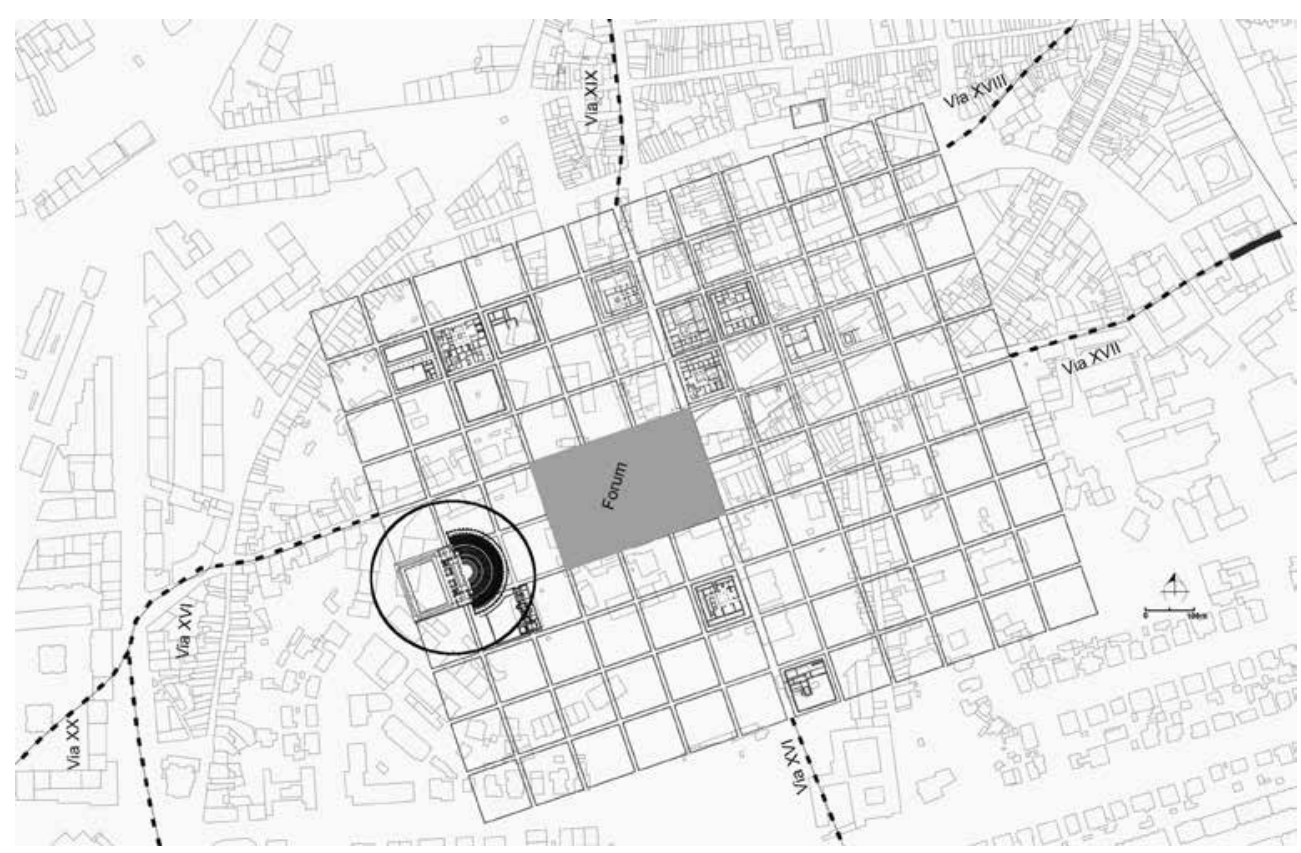

Fig. 1. Planta de Bracara Augusta no Alto Império com a localização do teatro. Fonte: @UAUM.

que parecem sugerir uma escadaria monumental, que deveria descer desde a fachada poente do foro até à zona do porticus post scaenam. Esta construção revela três aspetos essenciais: a sua inserção num espaço já urbanizado, a sua adaptação a topografia do terreno e ainda a observação de uma tradição local de construção.

A construção de cada parte do edifício foi resolvida com base na solução menos dispendiosa, considerando naturalmente as cargas e os riscos estruturais previsíveis. Por sua vez, o modo como o edifício assentou no terreno é revelador da estratégia da sua implantação e adaptação, escolhidas pelos seus desenhadores, combinando harmoniosamente o uso de pequeno e grande aparelho.

\section{PROCESSO CONSTRUTIVO}

A construção deste edifício deve ter constituído uma das grandes obras urbanas de Bracara Augusta, tendo certamente envolvido importantes meios financeiros e humanos, durante um período de tempo considerável.

Decidida a construção do edifício por parte das entidades políticas que governavam a cidade e viabilizado o seu financiamento, deve ter sido designado um responsável (curator) para coordenar a realização das obras. Dada a dimensão do edifício, deverão mesmo ter sido realizados vários contratos públicos com construtores individuais (redemptores) ou sociedades (societates publicanorum). 
A construção deve ter-se iniciado com os trabalhos de adaptação do terreno, cortando o maciço de pedra presente naquele local e conferindo-lhe uma forma côncava (Fig. 2). Assim, numa primeira fase deve ter sido construída a cavea e o muro perimetral, definindo-se, simultaneamente, a dimensão e profundidade da orchaestra e do aditus. A topografia particular da zona onde assentaram estes compartimentos obrigou ao corte vertical da rocha, transformando o aditus norte num muro de
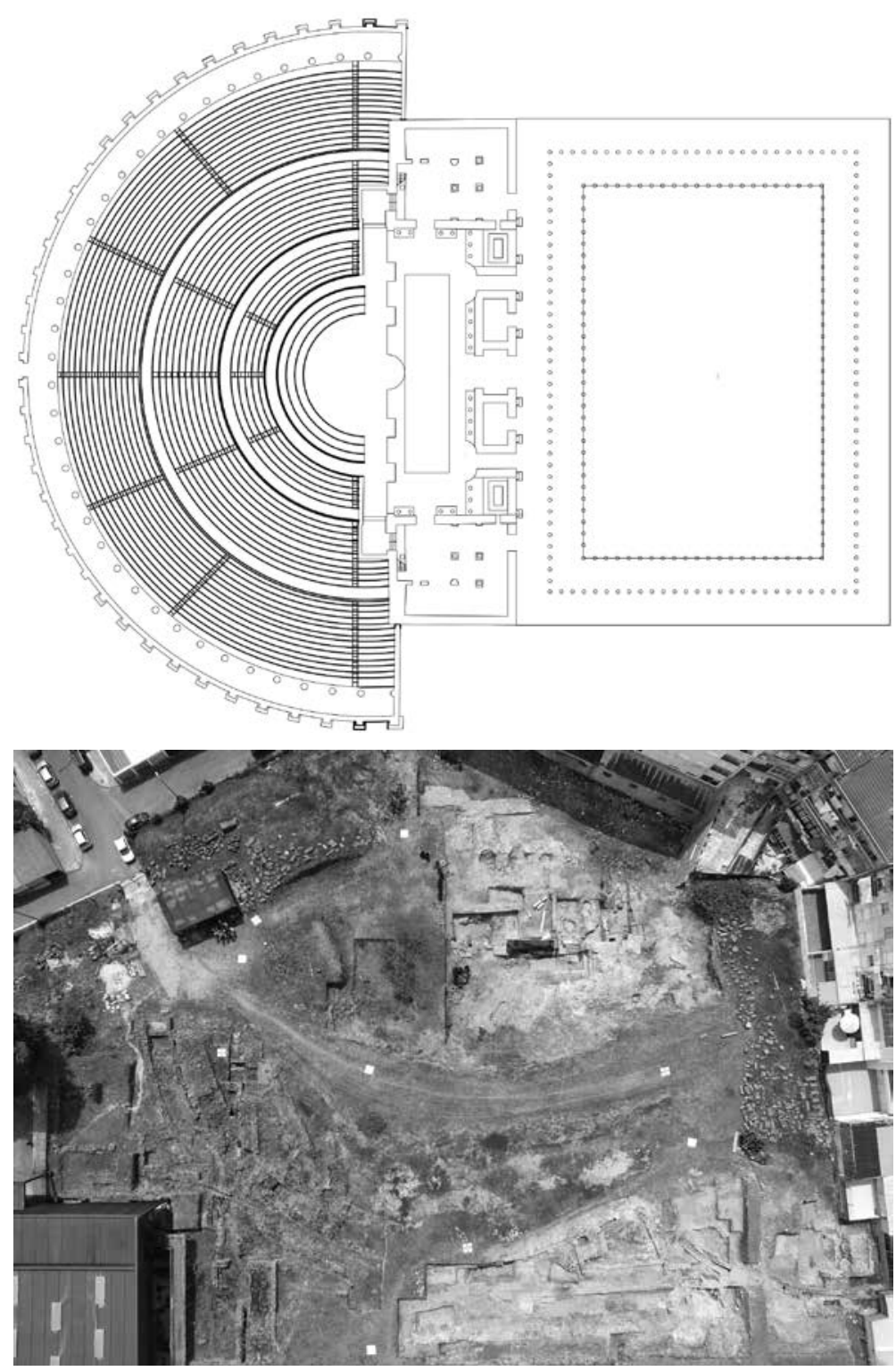

Fig. 2.

Proposta de planta do teatro (em cima). Fonte: CUAUM.

Perspetiva geral do edifício (em baixo). Fonte: CUAUM 
contenção e substrutura do conjunto. Definidos o comprimento e a altura da scaena, seria imprescindível levantar o muro do postcaenium, assim como os embasamentos da frons scaena, etapa que obrigava igualmente a estabelecer as fixações dos muros estruturais das basílicas, articuladas com o muro de fecho do edifício e a frente cénica. Terminada esta fase dos trabalhos, deve ter-se iniciado a colocação das bancadas, a construção dos tribunalia e do porticus in summa cavea. Seguidamente, devem ter sido realizados os fechos das basílicas e do porticus post scaenam, com os respetivos telhados. Possivelmente, nesta altura, devem ter sido colocados os pavimentos em pedra que revestiam a orchaestra, os aditi e os pórticos. Finalmente, e para concluir a obra, deve ter sido iniciado o programa decorativo da frons pulpiti e da frons scaena.

\section{ESTIMATIVA DO CUSTO DA ORNAMENTAÇÃO DA FRENTE CÉNICA}

\subsection{Metodologia de cálculo}

A base metodológica desta linha de investigação tem origem num estudo inovador da autoria de Janet DeLaine sobre o processo construtivo das Termas de Caracalla, publicado em 1997, no qual a autora introduz uma série de parâmetros temporais e económicos ${ }^{4}$. Nos últimos anos, têm sido várias as contribuições no sentido de apurar este método de cálculo, tendo por base dois documentos fundamentais: o Édito de Diocleciano, que fornece preços e salários de mais de 1000 itens, para os inícios do século IV $^{5}$ e os manuais de arquitetura e engenharia do século XIX, em particular o manual de Pegoretti, que estabelece os tempos necessários para a realização das principais tarefas associadas ao processo arquitetónico ${ }^{6}$. Para além do trabalho de Janet DeLaine, haverá igualmente que destacar o contributo de Paolo Barresi que, trabalhando a arquitetura pública da Ásia Menor, estimou, entre outros aspetos, os preços dos principais mármores usados na Antiguidade ${ }^{7}$. No que respeita à pedra local, os avanços realizados devem bastante aos trabalhos publicados por Ricardo Mar e Patrizio Pensabene, para o Forum Provincial de Tarraco ${ }^{8}$, bem como à análise de Begoña Soler, sobre o custo do programa ornamental do teatro de Cartagena', paralelo muito valioso para a proposta que aqui apresentamos. O contributo de Javier Domingo ${ }^{10}$ é igualmente digno de destaque na medida em que estabeleceu propostas que procuram validar os resultados obtidos através da metodologia de cálculo, con-

\footnotetext{
${ }^{4}$ DELAINE, 1997.

${ }^{5}$ GIACCHERO, 1974.

${ }^{6}$ PEGORETTI, 1869.

${ }^{7}$ BARRESI, 2000.

${ }^{8}$ MAR \& PENSABENE, 2010.

${ }^{9}$ SOLER, 2012.

${ }^{10}$ DOMINGO, 2012a; DOMINGO, 2012b; DOMINGO, 2013.
} 
frontando os mesmos com dados fornecidos pela epigrafia e pela literatura antiga, que revelam o custo de parte/ ou da totalidade de certos edificados.

Assim, o método que seguimos recorre aos valores enunciados pelo Édito de Diocleciano, que podem ser convertidos, se necessário, para épocas anteriores, extrapolando os preços com base na evolução do preço do modium castrense de farinha entre o século I e o século IV, bem como aos valores temporais estabelecidos em Pegoretti ${ }^{11}$.

Será necessário ter em conta, no entanto, neste tipo de exercícios, que existem variáveis muito dificilmente ponderáveis e situações impossíveis de detetar por via da arqueologia, que é e será uma das nossas principais fontes. Entre elas destacam-se as condições meteorológicas, o contributo ou não do trabalho escravo, a oferta eventual por parte de evergetas de determinados materiais, ou ainda a existência de realidades económicas distintas nos vários pontos que constituíam o império. Assim, permitimo-nos salientar que um edifício como o teatro de Niceia, a avaliar pela correspondência de Plínio o Jovem, terá custado mais de quatro vezes os valores estimados através da metodologia de cálculo que iremos utilizar ${ }^{12}$.

Nesta análise, apoiamo-nos em determinadas constantes, designadamente, em jornadas de trabalho (jt) de 10 horas e salários diários médios de 2 HS (com alimentação). Quanto ao preço da matéria-prima, tivemos em conta o trabalho de Paolo Barresi, que nos fornece uma tabela com as conversões dos preços dos mármores contemplados no Édito para um contexto do século I/II, permitindo-nos estimar o preço da pedra local, exclusivamente usada nesta obra, a qual teria um custo quatro vezes inferior ao do mármore mais barato mencionado no Édito, o que equivaleria sensivelmente a $1 \mathrm{HS}$ por pé cúbico $\left(\mathrm{p}^{3}\right)^{13}$. Um pé cúbico, por sua vez, terá a seguinte conversão: $1 \mathrm{~m}^{3}=38.5 \mathrm{p}^{3}$.

\subsection{A decoração arquitetónica do teatro}

Ricardo Mar propõe para a frente cénica do teatro de Braga uma dupla columnatio de 48 colunas. Do conjunto original, conseguiu-se recuperar uma base ática, duas bases toscanas, dois fustes completos, embora partidos, três outros fragmentos de fuste e dois fragmentos de capitéis (Fig. 3). Os fustes revelam dois tipos de diâmetros, correspondendo, possivelmente, a cada um dos andares. Foi possível ainda recolher vários fragmentos de elementos de remate, que parecem pertencer ao podium, um dos quais configurando uma peça de ângulo. Finalmente, no que concerne ao

\footnotetext{
${ }^{11}$ Os dados fornecidos pelo Édito permitem a transformação das horas de trabalho, estabelecidas por Pegoretti, em custo económico.

12 BARRESI, 2010: 347-348.

${ }^{13}$ MAR \& PENSABENE, 2010: 508-509.
} 


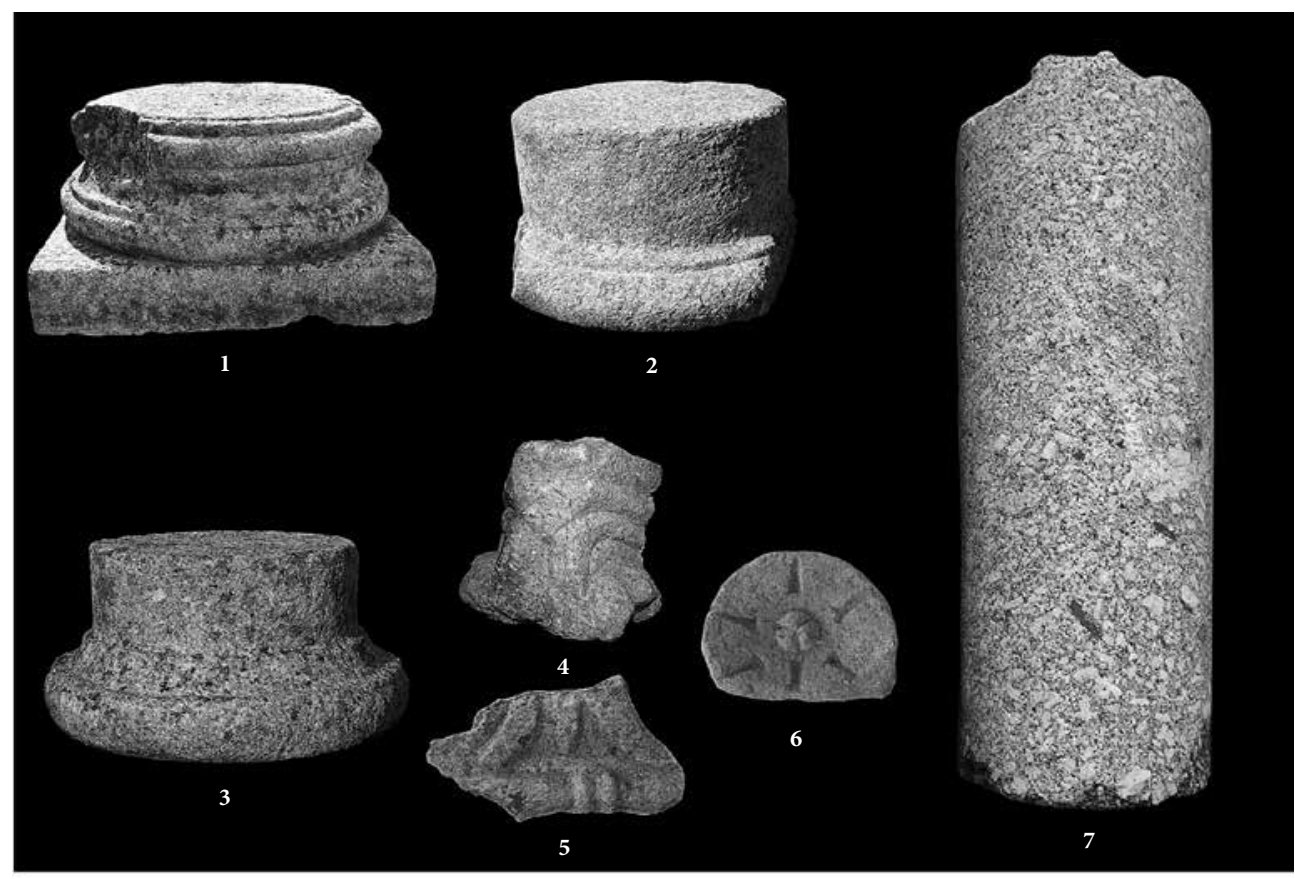

Fig. 3. 1: Base ática do primeiro andar; 2-3: Bases toscanas; 4: Fragmento de capitel coríntio; 5: Fragmento de capitel jónico; 6: Roseta; 7: Fragmento de fuste polido do primeiro andar. Fonte: @UAUM.

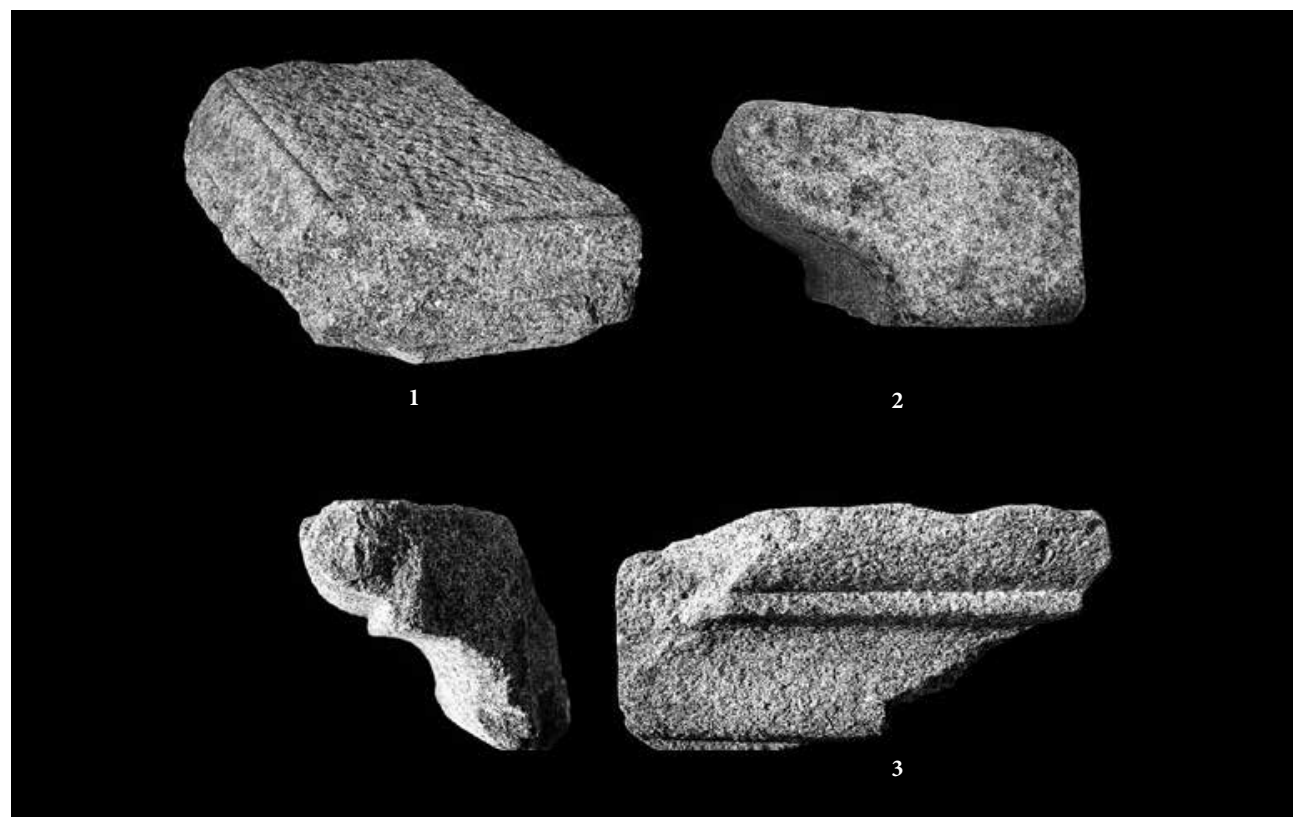

Fig. 4. 1: Elemento de canto de remate do podium; 2-3: Fragmentos de cornijas. Fonte: @UAUM. 
entablamento, as escavações realizadas permitiram recuperar vários fragmentos de cornijas, exibindo dimensões distintas, bem como uma pequena roseta (Fig. 4).

\subsubsection{Os granitos da columnatio}

A observação realizada resulta de uma análise macroscópica dos diversos elementos que nos parecem ter integrado o programa arquitetónico da frente cénica do teatro ${ }^{14}$. Assim, identificámos granitos leucocráticos com grão médio, denominados granitos de Barcelos, expressão que remete para as manchas situadas à saída de Braga, na direção de Barcelos, abrangendo as freguesias de Sequeira, Gondizalves, Pousa e Areias de Vilar. Algumas peças foram realizadas num granito de grão médio, apresentando alguma alteração, característico da mancha de Gonça (Guimarães). Comparativamente com o granito anterior, o granito de Gonça apresenta uma maior concentração de biotites e fenocristais, ausentes no primeiro. Foi evidenciada igualmente a presença de granitos provenientes da mancha de Braga, muito biotíticos, com grão fino e algo mais porfiróides que a variante de Barcelos. Foi também detetado um granito de grão mais grosseiro e tonalidade clara, devido à presença importante de fenocristais feldspáticos, exibindo ainda grandes encraves microgranulares acinzentados: o granito da Póvoa de Lanhoso. Trata-se de uma variante pouco meteorizada que está por norma associada a redes de fratura mais esparsas, permitindo a extração de blocos de grande dimensão. Em contrapartida, será um granito mais difícil de trabalhar do ponto de vista arquitetónico, justamente devido às características do seu grão. Os fustes da frente cénica foram elaborados precisamente nesse granito ${ }^{15}$. Este aspeto é sem dúvida revelador de uma oficina bastante qualificada.

Tudo isto sugere a aquisição de materiais a pedreiras distintas, permitindo um ritmo adequado dos trabalhos. O granito, por natureza, constitui um material relativamente difícil de trabalhar e as variantes com grão mais fino, como alguns dos granitos de Braga, Barcelos ou Gonça, seriam como tal mais apropriadas para o trabalho arquitetónico. Esta matéria requere contudo alguma prudência, na medida em que uma mesma mancha pode exibir ocorrências diferenciadas na sua extensão.

\subsubsection{Produção e custo dos elementos que formalizam a decoração da scaenae frons (Quadros 1 e 2)}

Giovanni Pegoretti indica que as tarefas ligadas à elaboração de um elemento decorativo em pedra articulam-se em quatro etapas principais: corte e extração, desbaste, aparelho rústico e acabamento, normalmente já realizado em obra. No que respeita aos fustes de coluna monolíticos, designadamente em mármore, Barresi

\footnotetext{
${ }^{14}$ Para a qual contamos com a ajuda e orientações do Professor Carlos Alves, do Departamento de Ciências da Terra da Universidade do Minho (DCET).

${ }^{15}$ Os degraus que formalizam o acesso entre o aditus e a basílica norte foram fabricados no mesmo granito.
} 


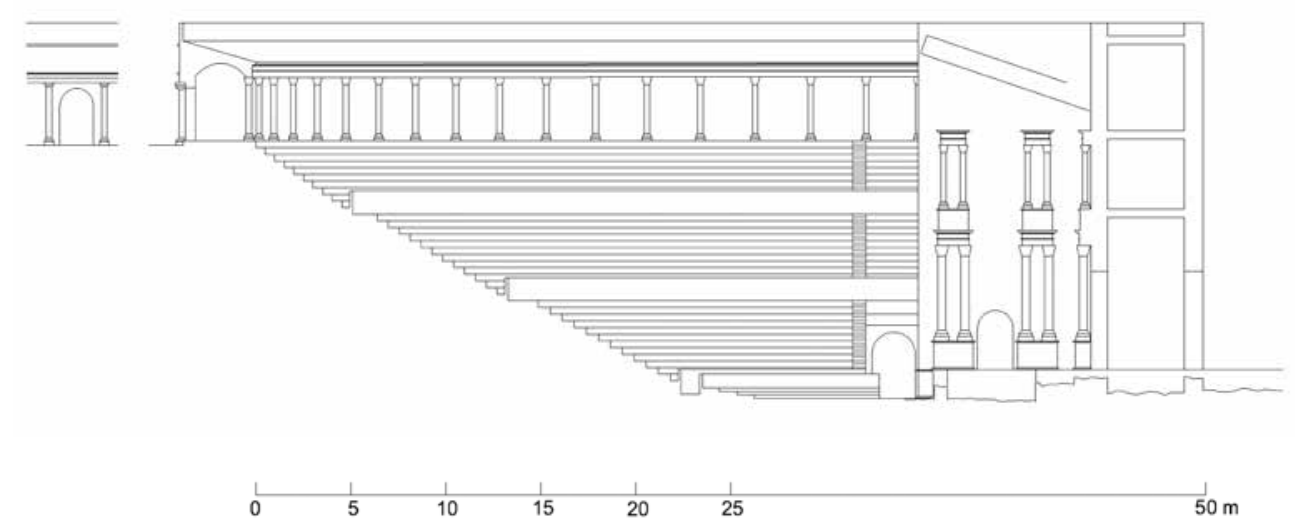

Fig. 5. Proposta de restituição da secção do teatro. Fonte: @UAUM.

assinala que eram desbastados diretamente na pedreira. Já na obra, eram realizados a entasis e o alisamento ${ }^{16}$.

A identificação de granitos de origem diferenciada em determinados elementos da frente cénica, como nos remates do podium, poderá denunciar que os blocos chegavam à obra grosseiramente desbastados, pelo que seriam as oficinas aí instaladas que realizariam as tarefas mais delicadas. Aliás, julgamos que não será de todo incorreto dizer que a própria dimensão do empreendimento, bem como o volume de materiais utilizado, reforçam essa hipótese.

Com base na restituição arquitetónica proposta por Ricardo Mar (Fig. 5), calculámos quantidades, volumes e pesos. A estimativa dos custos passa pela conversão desses valores em horas de trabalho e custos monetários, adicionando posteriormente o custo com o transporte. A restituição do volume total de pedra utilizado (volume bruto) em cada um destes elementos arquitetónicos deverá ter em conta, todavia, que nas pedreiras eram extraídos blocos paralelepípedos que apenas eram esquadriados e semielaborados posteriormente, até se obter a forma aproximada das peças, fossem elas bases, fustes ou capitéis ${ }^{17}$.

\subsubsection{Preço da matéria-prima (expresso em pé3)}

O cálculo do custo da matéria-prima utilizada considerou o volume bruto do material extraído da pedreira destinado à elaboração dos remates do podium, bases, fustes, capitéis e entablamentos, que multiplicamos pelo preço estimado da pedra local: $1 \mathrm{HS} /$ pé $^{3}$. O referido valor contempla já o custo com as tarefas de corte e extração do bloco.

\footnotetext{
${ }^{16}$ BARRESI, 2002: 69.

${ }^{17}$ DOMINGO, 2012b: 402.
} 
No que respeita aos fustes, tal como sugerido por Javier Domingo ${ }^{18}$, acrescentamos ao bloco original $5 \mathrm{~cm}$ de lado, correspondentes ao volume de pedra rebaixado na fase de semi-elaboração destas peças.

O volume de pedra utilizado nos diversos elementos é assim o seguinte: 6,85 $\mathrm{m}^{3}$ nos remates do podium, $4.72 \mathrm{~m}^{3}$ nas bases, $21.24 \mathrm{~m}^{3}$ nos fustes, $6.71 \mathrm{~m}^{3}$ nos capitéis e, finalmente, $15.25 \mathrm{~m}^{3}$ nos entablamentos, o que perfaz um total de $54.77 \mathrm{~m}^{3}$.

$21.24 \mathrm{~m}^{3}$ (granito da Póvoa de Lanhoso) $+33.53 \mathrm{~m}^{3}$ (leucogranitos) $=$ $54.77 \mathrm{~m}^{3}$

$$
\begin{aligned}
& 54.77 \mathrm{~m}^{3}=2109 \mathrm{p}^{3} \\
& 2109 \mathrm{p}^{3} \times 1 \mathrm{HS}=2109 \mathrm{HS} / 527 \mathrm{D}
\end{aligned}
$$

\subsubsection{Preço do trabalho rústico (expresso em horas de trabalho por $\mathrm{m}^{3}$, na pedreira)}

O trabalho rústico consiste na atribuição da dimensão desejada ao bloco extraído da pedreira. Neste cálculo, consideramos a variável de 448 horas $/ \mathrm{m}^{3}$ definida por Pegoretti para o granito comum ${ }^{19}$.

Remates do podium:

$6.85 \mathrm{~m}^{3} \mathrm{x} 448$ horas $/ \mathrm{m}^{3}=3068.8$ horas de trabalho (ht)

$3068.8 \mathrm{ht} / 10 \mathrm{~h}$ (jornada de trabalho/ jt) $=307 \mathrm{jt}$

$307 \mathrm{jt} \times 2 \mathrm{HS}=614 \mathrm{HS} / 153.5 \mathrm{D}$

Colunas:

$32.67 \mathrm{~m}^{3} \times 448 \mathrm{~h} / \mathrm{m}^{3}=14636.2 \mathrm{ht}$

$14636.2 \mathrm{ht} / 10 \mathrm{~h}=1463.6 \mathrm{jt}$

$1463.6 \mathrm{jt} \times 2 \mathrm{HS}=2927 \mathrm{HS} / 731.8 \mathrm{D}$

Entablamento

$15.25 \mathrm{~m}^{3} \times 448 \mathrm{~h} / \mathrm{m}^{3}=6832 \mathrm{ht}$

$6832 \mathrm{ht} / 10 \mathrm{~h}=683.2 \mathrm{jt}$

$683.2 \mathrm{jt} \times 2 \mathrm{HS}=1366 \mathrm{HS} / 341.6 \mathrm{D}$

Total

$54.77 \mathrm{~m}^{3} \mathrm{x} 448 \mathrm{~h} / \mathrm{m}^{3}=24537 \mathrm{ht}$

$24537 \mathrm{ht} / 10 \mathrm{~h}=2454 \mathrm{jt}$

$2454 \mathrm{jt} \times 2 \mathrm{HS}=4908 \mathrm{HS} / 1227 \mathrm{D}$

\footnotetext{
${ }^{18}$ DOMINGO, 2012b: 402.

${ }^{19}$ PEGORETTI, 1869: 291 (Tabella ottava).
} 


\subsubsection{Preço da semi-elaboração (expressa em horas de trabalho por $\mathbf{m}^{2}$, na pedreira)}

A semi-elaboração consiste numa segunda etapa do tratamento dado aos elementos arquitetónicos após o desbastamento inicial, que reside na atribuição de uma forma grosseira com base na função arquitetónica desejada: base, fuste, capitel, etc.. Corresponde à superfície total trabalhada. Será calculado separadamente o trabalho realizado nas bases/ capitéis daquele dos fustes.

No caso dos fustes, a estimativa das horas de trabalho será realizada com base na fórmula [a $\mathrm{x}\left(2+\frac{0.25}{x}\right)$ ], em que a consiste numa variável que para o caso dos granitos comuns corresponde a 12 , enquanto $\mathbf{x}$ está associado ao diâmetro do imoscapo.

Fustes do $1^{\circ}$ andar: $12 \times\left(2+\frac{0.25}{0,43}\right)=30.97$ horas $/ \mathrm{m}^{2}$

Superfície dos fustes: $2 \pi \mathrm{r} \times$ altura do fuste $=2 \times 3.1416 \times 0.215 \times 3=4.05 \mathrm{~m}^{2}$ Portanto 30.97 horas $/ \mathrm{m}^{2}$ x $4.05 \mathrm{~m}^{2}=125.43 \mathrm{ht} /$ fuste

125.43 ht $\times 24=3010.32 \mathrm{ht}$

$=3010.32 \mathrm{ht} / 10 \mathrm{~h}=301.03 \mathrm{jt}$

301.03 jt $x 2 \mathrm{HS}=602.06 \mathrm{HS} / 150.5 \mathrm{D}$

Fustes do $2^{\circ}$ andar: $12 \mathrm{x}\left(2+\frac{0.25}{0,24}\right)=36.5$ horas $/ \mathrm{m}^{2}$

Superfície dos fustes: 2 × 3.1416 × $0.12 \times 2.14=1,61 \mathrm{~m}^{2}$

Portanto 36.5 horas $/ \mathrm{m}^{2} \times 1.61 \mathrm{~m}^{2}=58.76 \mathrm{ht} /$ fuste

58.76 ht x $24=1410.24 \mathrm{ht}$

$1410.24 \mathrm{ht} / 10 \mathrm{~h}=141.02 \mathrm{jt}$

141.02 jt $\times 2 \mathrm{HS}=282.04 \mathrm{HS} / 70.5 \mathrm{D}$

No que respeita às bases e capitéis, aplicamos a fórmula $\left[a\left(1+\frac{0.25}{x}\right)\right]$ onde $a$ variável a corresponde a 12 e $\mathbf{x}$ ao diâmetro do capitel/base.

Capitéis do $1^{\circ}$ andar: $12 \mathrm{x}\left(1+\frac{0.25}{0,40}\right)=19.5$ horas $/ \mathrm{m}^{2}$

Superfície trabalhada do capitel: $0.89 \mathrm{~m}^{2}$

Portanto $19.5 \mathrm{~h} / \mathrm{m}^{2} \times 0.89 \mathrm{~m}^{2}=17.36 \mathrm{ht} /$ capitel

$17.36 \mathrm{ht} \times 24=416.64 \mathrm{ht}$

$416.64 \mathrm{ht} / 10 \mathrm{~h}=41.66 \mathrm{jt}$

41.66 jt $\times 2 \mathrm{HS}=83.33 \mathrm{HS} / 20.8 \mathrm{D}$

Capitéis do $2^{\circ}$ andar: $12 \mathrm{x}\left(1+\frac{0.25}{0,24}\right)=24.5$ horas $/ \mathrm{m}^{2}$

Superfície trabalhada do capitel: $0.46 \mathrm{~m}^{2}$

Portanto $24.5 \mathrm{~h} / \mathrm{m}^{2} \times 0.46 \mathrm{~m}^{2}=11.27 \mathrm{ht} /$ capitel

$11.27 \mathrm{ht} \times 24=270.48 \mathrm{ht}$

$270.48 \mathrm{ht} / 10 \mathrm{~h}=27.05 \mathrm{jt}$

$27.05 \mathrm{jt} \times 2 \mathrm{HS}=54.1 \mathrm{HS} / 13.5 \mathrm{D}$ 
Bases do $1^{\circ}$ andar: $12 \mathrm{x}\left(1+\frac{0.25}{0,44}\right)=18.82$ horas $/ \mathrm{m}^{2}$

Superfície trabalhada da base: $0.70 \mathrm{~m}^{2}$

Portanto $18.82 \mathrm{~h} / \mathrm{m}^{2} \times 0.70=13.17 \mathrm{ht} /$ base

$13.17 \mathrm{~h} \mathrm{x} 24=316.08 \mathrm{ht}$

$316.08 \mathrm{ht} / 10=31.61 \mathrm{jt}$

31.61 jt x $2 \mathrm{HS}=63.22 \mathrm{HS} / 15.8 \mathrm{D}$

Bases do $2^{\circ}$ andar: $12 \mathrm{x}\left(1+\frac{0.25}{0,37}\right)=20.11$ horas $/ \mathrm{m}^{2}$

Superfície trabalhada da base: $0.54 \mathrm{~m}^{2}$

Portanto $20.11 \mathrm{~h} / \mathrm{m}^{2}$ x $0.54=10.86 \mathrm{ht} /$ base

$10.86 \mathrm{~h} \mathrm{x} 24=260.64 \mathrm{ht}$

$260.64 \mathrm{ht} / 10=20.06 \mathrm{jt}$

20.06 jt $\times 2 \mathrm{HS}=40.12 \mathrm{HS} / 10 \mathrm{D}$

Total: 1124.4 HS/ 281.1 D

\subsubsection{Custos com o transporte dos elementos}

O custo do transporte é calculado com base em três variáveis distintas: o meio utilizado, neste caso por terra, a distância e o volume/peso do material transportado, aqui correspondendo praticamente ao volume final de cada elemento.

Tal como indicamos, a decoração da frente cénica do teatro foi realizada com quatro variantes de granito local, com algumas diferenças a nível de composição e de cor: maioritariamente leucogranitos, que associamos à «zona de Barcelos» ${ }^{20}$ e um granito de grão fino a médio com grandes megacristais de feldspato potássico, facto que confere a esse material, uma vez alisado e polido, um aspeto superficial algo marmóreo, designado como granito da Póvoa de Lanhoso, do qual faz parte a mancha de Donim.

As pedreiras exploradas na Antiguidade não foram ainda identificadas, no entanto conseguimos definir as grandes manchas onde estas estariam localizadas. A observação conjunta dessas manchas e da projeção das vias que saíam da cidade, permitiu-nos a determinação de distâncias médias. Assim, as pedreiras da «zona de Barcelos» ficariam a uma distância mínima de $4.5 \mathrm{~km}$ (Gondizalves) e máxima de $15 \mathrm{~km}$ (Areais de Vilar) de Bracara Augusta, o que perfaz uma média de $9.6 \mathrm{~km}$, ou seja, 6.5 milhas $^{21}$. O transporte deverá ter sido efetuado por terra, usando para tal o percurso sugerido pela Via XX e algum dos eixos secundários ou terciários que entroncaria na mesma. No que respeita às pedreiras da mancha da Póvoa de Lanhoso, como é o caso da área Donim, estas seriam acessíveis por diversos divertículos que entroncariam quer na Via XVII (Bracara - Asturica), quer na Via Bracara - Tongobriga,

\footnotetext{
${ }^{20}$ Por zona de Barcelos, entendemos as manchas graníticas situadas à saída da cidade, na direção de Barcelos, bem como manchas localizadas já na própria região de Barcelos.

${ }^{21}$ Estabelecendo um valor médio entre as quatro manchas identificadas. 1 milha romana equivale a $1481 \mathrm{~m}$.
} 
ficando respetivamente a cerca de 16 e $13 \mathrm{~km}$ da cidade, ou seja, aproximadamente a 11 e 9 milhas, o que perfaz uma média de 10 milhas.

Existem dois métodos para o cálculo dos custos do transporte por via terrestre ${ }^{22}$. O primeiro, desenvolvido por Janet DeLaine ${ }^{23}$, baseia-se na seguinte fórmula: [0.85 denários (século II) $\mathrm{x} \mathrm{m}^{3} \mathrm{x}$ milha]. O segundo é-nos sugerido pelo Édito de Diocleciano e permite a definição da seguinte fórmula: [0.52 denários (século II) $\mathrm{x}$ tonelada $\mathrm{x}$ milha ${ }^{24}$. A densidade média do granito situa-se nas $2.7 \mathrm{gramas} / \mathrm{cm}^{3}$, o que equivale a $2.7 \mathrm{t} / \mathrm{m}^{3}$, peso que corresponde ao máximo que um carro de bois poderia transportar por viagem. A este propósito, Pegoretti ${ }^{25}$ diz-nos que um carro de bois consegue fazer, carregado, um máximo de $15 \mathrm{~km}$ por $\mathrm{dia}^{26}$, o que corresponde sensivelmente à distância média a que se situam as pedreiras que abasteciam Bracara Augusta.

Portanto, com base na primeira fórmula [0.85 denários (século II) $\mathrm{x} \mathrm{m}^{3} \mathrm{x}$ milha] temos os seguintes valores:

Volume dos remates do podium: $6.85 \mathrm{~m}^{3}$

Portanto: $0.85 \mathrm{D}$ x $6.85 \mathrm{~m}^{3}$ x 6.5 milhas $=37.85 \mathrm{D}$

Volume das bases: $4.72 \mathrm{~m}^{3}$

Portanto: $0.85 \mathrm{D}$ x $4.72 \mathrm{~m}^{3}$ x 6.5 milhas $=26 \mathrm{D}$

Volume dos fustes: $21.24 \mathrm{~m}^{3}$

Portanto: $0.85 \mathrm{D} \times 21.24 \mathrm{~m}^{3} \times 10$ milhas $=180.5 \mathrm{D}$

Volume dos capitéis: $6.71 \mathrm{~m}^{3}$

Portanto: $0.85 \mathrm{D} \times 6.71 \mathrm{~m}^{3} \times 6.5$ milhas $=37 \mathrm{D}$

Volume dos elementos do entablamento: $15.25 \mathrm{~m}^{3}$

Portanto: $0.85 \mathrm{D}$ x $15.25 \mathrm{~m}^{3}$ x 6.5 milhas $=84.5 \mathrm{D}$

Custo total de $365.85 \mathrm{D}$

Se recorrermos à segunda fórmula [0.52 denários (século II) $\mathrm{x}$ tonelada $\mathrm{x}$ milha] obtemos os seguintes valores:

Massa dos remates do podium: $6.85 \mathrm{~m}^{3}(18.5 \mathrm{t})$

Portanto: $0.52 \times 18.5 \mathrm{t} \times 6.5=62.5 \mathrm{D}$

Massa das bases: $4.72 \mathrm{~m}^{3}(12.75 \mathrm{t})$

Portanto: $0.52 \times 12.75 \mathrm{t} \times 6.5=43.1 \mathrm{D}$

Massa dos fustes: $21.24 \mathrm{~m}^{3}(57.35 \mathrm{t})$

Portanto: $0.52 \times 57.35 \mathrm{t} \times 10=298.2 \mathrm{D}$

\footnotetext{
${ }^{22}$ DOMINGO, 2012b: 405.

${ }^{23}$ DELAINE, 1997: 210-211.

${ }^{24}$ GIACCHERO apud DOMINGO, 2012b: 405.

${ }^{25}$ PEGORETTI apud DOMINGO, 2012b: 405.

${ }^{26}$ PRISSET, 2008: 135.
} 
Massa dos capitéis: $6.71 \mathrm{~m}^{3}(18.12 \mathrm{t})$

Portanto: $0.52 \times 18.12 \mathrm{t}$ x $6.5=61.25 \mathrm{D}$

Massa dos elementos do entablamento: $15.25 \mathrm{~m}^{3}(41.18 \mathrm{t})$

Portanto: 0.52 x 41.18 t x $6.5=139.2 \mathrm{D}$

Custo total de 604.2 D

A margem de erro associada ao custo do transporte poderá ser corrigida fazendo uma média entre os valores obtidos com base nas duas fórmulas, o que perfaz um custo aproximado de $485 \mathrm{D}\left(\frac{604.2+365.85}{2}\right)$.

\subsubsection{Acabamento dos elementos}

Esta fase corresponde à última etapa do tratamento dos elementos, em alguns casos realizada já com as peças in situ.

No que concerne aos capitéis, o manual de Pegoretti fornece-nos um valor numérico para o acabamento de um exemplar coríntio em diversos materiais mas não estabelece essa variável para o caso do granito. Nesse sentido, optamos pela variável associada a uma rocha com valores bastante próximos do granito comum: o mármore negro Portoro, isto é 1296 horas para exemplares com cerca de $0.50 \mathrm{~m}$ de altura, como é o caso dos capitéis do primeiro andar (com $0.40 \mathrm{~m}$ de altura restituída), e 864 horas para exemplares com $0.33 \mathrm{~m}$ de altura, que corresponde sensivelmente ao caso dos capitéis do segundo andar $(0.31 \mathrm{~m} \text { de altura restituída })^{27}$. No que respeita a esta questão, Begoña Soler Huertas, no seu trabalho sobre o custo da marmorização da frente cénica do teatro de Cartagena, considera que os valores que encontramos em Pegoretti correspondem a oficinas comuns, cuja qualidade não seria de todo comparável com a mão-de-obra responsável pelo acabamento dos capitéis daquele edifício ${ }^{28}$. Nesse sentido, esta autora duplica o valor da variável enunciada por Pegoretti. Em contrapartida, Javier Domingo, no seu estudo sobre o Capitólio de Volubilis, ornamentado com grandes capitéis coríntios lisos em calcário, reduz para $1 / 4$ a variável estabelecida por Pegoretti ${ }^{29}$. Pese embora termos recuperado apenas dois pequenos fragmentos de capitéis $^{30}$, que requerem uma análise mais aprofundada, cremos que é justo valorizar o nível de especialização da oficina ou das oficinas que os realizaram, mantendo os valores determinados por Pegoretti, tendo em conta a dificuldade e a exigência que eram solicitadas a um lapidarius bracarense para transformar em granito um elemento pensado para o mármore ou o calcário, materiais muito mais fáceis de trabalhar.

\footnotetext{
${ }^{27}$ PEGORETTI, 1869: 270.

${ }^{28}$ SOLER, 2012: 216.

${ }^{29}$ DOMINGO, 2012b: 409.

${ }^{30}$ Os dois fragmentos recuperados são de reduzida dimensão, o que por si só dificulta o seu estudo, no entanto exibem características que parecem não corresponder a um trabalho de inícios do século II.
} 
Assim:

Capitéis do $1^{\circ}$ andar: 1296 × $24=31104$ horas

31104 horas $/ 10$ horas $=3110 \mathrm{jt}$

3110 jt $\times 2$ HS = $6220 \mathrm{HS} / 1555 \mathrm{D}$

Capitéis do $2^{\circ}$ andar: 864 x $24=20736$ horas

20736 horas $/ 10$ horas $=2073.6 \mathrm{jt}$

2073.6 jt $\times 2$ HS = 4147.2 HS/ 1036.8 D

No que respeita ao acabamento das bases, encontra-se estabelecido que poderá ser estimado em 1/3 do valor dos capitéis, pelo que teríamos:

Bases do $1^{\circ}$ andar: $\frac{1555}{3}=518.4 \mathrm{D}$

Bases do $2^{\circ}$ andar: $\frac{1036.8}{3}=345.6 \mathrm{D}$

Quanto aos fustes, e na medida em que os fustes do teatro são lisos, seguimos as indicações de Pegoretti que refere que o acabamento de um elemento com superfície plana, em granito, exigia 16 horas de trabalho/ $\mathrm{m}^{2}$. A superfície dos fustes do primeiro andar é de $4.05 \mathrm{~m}^{2}$ e do segundo andar de $1.61 \mathrm{~m}^{2}$.

Assim:

Fustes do $1^{\circ}$ andar: 16 horas de trabalho $\mathrm{x} 4.05=64.8$ horas de trabalho (ht) / fuste

64.8 ht x $24=1555.2 \mathrm{ht}$

$1555.2 \mathrm{ht} / 10=155.5$ jornadas de trabalho $(\mathrm{jt})$

155.5 jt $x$ 2HS $=311 \mathrm{HS} / 77.8 \mathrm{D}$

Fustes do $2^{\circ}$ andar: 16 ht $x 1.61 \mathrm{~m}^{2}=25.76 \mathrm{ht} /$ fuste

25.76 ht x $24=618.24 \mathrm{ht}$

$618.24 \mathrm{ht} / 10=61.8 \mathrm{jt}$

61.8 jt $\times 2 \mathrm{HS}=123.6 \mathrm{HS} / 30.9 \mathrm{D}$

Finalmente, no que respeita aos elementos de remate, Pegoretti assinala que a realização de motivos decorativos simples num bloco de pedra granítica assume o valor de 355.20 horas/ $\mathrm{m}^{2} 31$. Os elementos recuperados no teatro exibem uma decoração bastante simplificada, pelo que consideramos que poderá ser um valor ajustado. A superfície total dos elementos que rematariam o podium estima-se em $5.5 \mathrm{~m}^{2}(27.52 \mathrm{~m} \times 0.20 \mathrm{~m})$, do entablamento do primeiro andar: $18 \mathrm{~m}^{2}(24.32 \mathrm{~m}$ x $0.74 \mathrm{~m})$ e, finalmente, do entablamento do segundo andar: $10.12 \mathrm{~m}^{2}(18.4 \mathrm{~m} \mathrm{x}$ $0.55 \mathrm{~m})$.

\footnotetext{
${ }^{31}$ PEGORETTI, 1869: 296.
} 
Assim:

Remates do podium: $5.5 \mathrm{~m}^{2}$ x $355.20 \mathrm{~h}=1953.6 \mathrm{ht}$

$1953.6 \mathrm{ht} / 10=195.4 \mathrm{jt}$

195.4 jt x $2 \mathrm{HS}=390.8 \mathrm{HS} / 97.7 \mathrm{D}$

Entablamento $1^{\circ}$ andar: $18 \mathrm{~m}^{2} \times 355.20 \mathrm{~h}=6393.6 \mathrm{ht}$

$6393.6 \mathrm{ht} / 10=639.4 \mathrm{jt}$

639.4 jt $\times 2 \mathrm{HS}=1278.8 \mathrm{HS} / 319.7 \mathrm{D}$

Entablamento $2^{\circ}$ andar: $10.12 \mathrm{~m}^{2}$ x $355.20 \mathrm{~h}=3594.6 \mathrm{ht}$

$3594.6 \mathrm{ht} / 10=359.5 \mathrm{jt}$

359.5 jt x $2 \mathrm{HS}=719 \mathrm{HS} / 179.8 \mathrm{D}$

Total: 16646.8 HS/ 4161.7 D

Quadro 1. Volumes aproximados de pedra utilizada.

\begin{tabular}{|c|c|}
\hline Elementos & Volume bruto $\left(\mathrm{m}^{3}\right)$ \\
\hline Remates podium & 6.85 \\
\hline Bases $1^{\circ}$ & 3.02 \\
\hline Bases $2^{\circ}$ & 1.7 \\
\hline Fustes $1^{\circ}$ & 16.6 \\
\hline Fustes $2^{\circ}$ & 4.64 \\
\hline Capitéis $1^{\circ}$ & 5.18 \\
\hline Capitéis $2^{\circ}$ & 1.53 \\
\hline Entablamento $1^{\circ}$ & 9.73 \\
\hline Entablamento $2^{\circ}$ & 5.52 \\
\hline Total & 54.77 \\
\hline
\end{tabular}

Quadro 2. Estimativa dos custos das diferentes tarefas associadas ao processo de produção dos elementos arquitetónicos da frente cénica do teatro.

\begin{tabular}{|c|c|c|c|c|c|}
\hline Elementos & $\begin{array}{c}\text { Material e extração } \\
\text { (D) }\end{array}$ & $\begin{array}{l}\text { Trab. rústico } \\
\text { (D) }\end{array}$ & $\begin{array}{c}\text { Semi-elaboração } \\
\text { (D) }\end{array}$ & $\begin{array}{c}\text { Transporte } \\
\text { (D) }\end{array}$ & $\begin{array}{c}\text { Acabamento } \\
\text { (D) }\end{array}$ \\
\hline Remates podium & 65.9 & 153.5 & & $37.85 / 62.5$ & 97.7 \\
\hline Bases $1^{\circ}$ & 29 & 67.65 & 15.8 & \multirow{2}{*}{$26 / 43.1$} & 518.4 \\
\hline Bases $2^{\circ}$ & 16.36 & 38 & 10 & & 345.6 \\
\hline Fustes $1^{\circ}$ & 160 & 371.84 & 150.5 & \multirow{2}{*}{$180.5 / 298.2$} & 77.8 \\
\hline Fustes $2^{\circ}$ & 44.7 & 103.94 & 70.5 & & 30.9 \\
\hline Capiteis $1^{\circ}$ & 49.85 & 116.03 & 20.8 & \multirow{2}{*}{$37 / 61.25$} & 1555 \\
\hline Capiteis $2^{\circ}$ & 14.73 & 34.3 & 13.5 & & 1036.8 \\
\hline Entablamento $1^{\circ}$ & 93.65 & 217.95 & & \multirow{2}{*}{$84.5 / 139.2$} & 319.7 \\
\hline Entablamento $2^{\circ}$ & 53.13 & 123.65 & & & 179,8 \\
\hline Total & 527 & 1227 & 281.1 & $\begin{array}{c}365.85 / 604 \\
485\end{array}$ & 4161.7 \\
\hline & & & & & $\begin{array}{c}6682 \text { D } \\
26728 \text { HS }\end{array}$ \\
\hline
\end{tabular}




\section{NOTAS CONCLUSIVAS}

Tendo em conta os valores estimados para as diferentes fases do processo de elaboração da frente cénica, apurámos um custo total de 26728 HS/ 6682 D que naturalmente deverá pecar por defeito. Na verdade, os valores aqui apresentados configuram apenas um pequeno exercício, meramente hipotético, que pretende contribuir para o conhecimento da escala de investimentos que terá implicado o processo de monumentalização da cidade, que incluiu a construção do teatro, bem como enriquecer os estudos dedicados à economia da construção que vimos desenvolvendo sobre vários edifícios de Bracara Augusta.

Os dados que avançamos apoiam-se apenas em evidências arqueológicas, sendo desconhecidas outras fontes que possam ajudar a apurar os resultados enunciados. Por outro lado, há variáveis impossíveis de apreciar, pelo que esperamos que as futuras escavações do teatro, bem como outros trabalhos desta natureza, possam vir a otimizar ou mesmo corrigir os resultados obtidos.

É-nos possível, contudo, emitir alguns comentários. Em primeiro lugar, o peso relativo deste investimento. Com efeito, é importante ter em conta que o valor estimado corresponde apenas a uma parte dos custos totais envolvidos nesta obra, possivelmente a maior fatia do investimento realizado. Por outro lado, importa referir as dificuldades associadas ao transporte dos fustes. Cada fuste do primeiro andar pesaria cerca de $1300 \mathrm{~kg}$, o que significa que cada carro de bois poderia transportar dois elementos por dia, possivelmente com mais do que uma junta. A título comparativo, o transporte dos fustes monolíticos do frontispício da igreja do Bom Jesus, extraídos da zona de Donim, exigiu o recurso a 24 juntas de bois, e conheceu várias dificuldades no seu percurso para Braga ${ }^{32}$.

Podemos ainda questionar a opção pelo material local. A lógica desta decisão deverá estar relacionada com uma economia de despesas. Sabemos que o mármore mais barato representava um custo quatro vezes superior ao da pedra local. Por outro lado, o transporte de longa distância, com mármore de Vila Viçosa, por exemplo, cuja presença foi atestada em Braga, aumentaria exponencialmente o custo da frente cénica. Esta componente atingiria proporções ainda mais elevadas se imaginarmos o recurso a qualquer um dos prestigiosos mármores que circulavam na bacia do Mediterrâneo. Desse modo, uma eventual aquisição de mármore importado de Roma, como o de Luni, faria com que o simples custo com o transporte da matéria-prima, por via marítima, fosse multiplicado por dez, passando dos $63 \mathrm{D}$ estimados para $639 \mathrm{D}$ (considerando apenas aqui bases e capitéis, segundo a fórmula de Janet Delaine). Assim, entende-se esta escolha, muito embora o granito tenha outra exigência em termos de trabalho, que se verifica numa maior duração de cada tarefa.

${ }^{32}$ OLIVEIRA, 2001: 95-102. 
No que respeita ao seu custo, a aquisição da matéria-prima foi calculada em $527 \mathrm{D}$, o que representa cerca de $8 \%$ do investimento total estimado, não diferindo muito das proporções estabelecidas por Duncan-Jones para a produção de estatuária em mármore: $90 \%$ para a mão-de-obra e $10 \%$ para o material ${ }^{33}$.

Ainda a respeito da matéria-prima, é interessante a opção pelo granito da Póvoa de Lanhoso/ Donim, para o fabrico dos fustes da columnatio, com um acabamento de grande qualidade ${ }^{34}$, que faz aqui o papel de material nobre. Estas escolhas deliberadas, que afastam esta construção dos vários programas marmóreos aplicados em muitos teatros hispânicos, não impediram que se recorresse a pedra de boa qualidade e a uma gama variada granitos, possibilitando certamente jogos de cores esteticamente bem conseguidos. Além disso, a aquisição de granitos provenientes de pedreiras distintas sugere um ritmo de obra relativamente intenso, pelo menos na fase de ornamentação da frente cénica, bem como a presença de oficinas locais.

No que respeita ao valor económico, os teatros seriam dos edifícios mais caros de construir no mundo romano. $\mathrm{O}$ valor estimado parece-nos bastante razoável e poderá ser comparado com outros dados conhecidos para a arquitetura teatral. Assim, Begoña Soler estabelece em 80952 HS o custo da marmorização da frente cénica do teatro de Cartagena ${ }^{35}$. Trata-se de um valor bastante superior mas que tem em parte explicação em volumes brutos de matéria-prima restituídos proporcionalmente mais elevados e igualmente no recurso à importação por via marítima de mármore lunense. Outros dados relacionados com os custos destas construções são-nos fornecidos pela epigrafia, fonte que deverá contudo ser manipulada com cautela, na medida em que é por vezes difícil saber a que parte exata da obra o valor documentado diz respeito. De forma a tornar o exercício mais realista, efetuamos, quando necessário, a conversão dos montantes anunciados para valores dos séculos I/II, com base no método proposto por Javier Domingo ${ }^{36}$. A marmorização da frente cénica do teatro de Leptis Magna (séculos I/II) está associada a um investimento colossal de 500000 HS, segundo uma inscrição de meados do século $\mathrm{II}^{37}$. Também o levantamento de seis estátuas e a construção do teatro de Madaurus, um dos mais pequenos da África romana, sob os Severos, com metade do diâmetro do teatro de Bracara Augusta, terá representado um investimento muito inferior: $375000 \mathrm{HS}$ (= $8333 \mathrm{HS}$ séculos I/II $)^{38}$. A construção de um simples proscaenium no teatro de Beda é-nos revelada por uma inscrição, datada de 198, que refere um custo de 50000 HS (= 1111 HS séculos I/II $)^{39}$.

\footnotetext{
${ }^{33}$ DUNCAN-JONES, 1974: 126.

${ }^{34}$ Material e acabamento documentados noutros edifícios da cidade.

35 SOLER, 2012: 217.

${ }^{36}$ DOMINGO, 2012a: 146.

${ }^{37}$ SOLER, 2012: 218.

${ }^{38}$ SEAR, 2006: 20.

${ }^{39}$ SEAR, 2006: 22.
} 
O embelezamento do teatro de Narbona encontra-se igualmente documentado, através de uma doação de 53000 HS (= 1178 HS) (finais século II) ${ }^{40}$. Outro ato evergeta (finais século II/ inícios do III) refere uma doação de 400000 HS (=9000 HS séculos I/II) para o teatro de Calama, na atual Argélia ${ }^{41}$. A construção de um cuneus da ima cavea do teatro de Jerash, por último, terá custado 12000 HS (finais século I) ${ }^{42}$.

Cremos que, com o recurso apenas ao material disponível localmente, os construtores do teatro conseguiram uma fachada cénica dinâmica e apoiada num programa bastante elaborado, respondendo a grandes exigências técnicas e estéticas e, globalmente, aos padrões da época. Por isso, deverá ser valorizada a qualidade técnica destes talhadores da pedra, capazes de transformar em granito modelos desenhados para o mármore ou o calcário, revelando uma perfeita assimilação das formas de construir romanas, mas incorporando claramente conhecimentos locais ancestrais.

Se pensarmos na obra do teatro como um todo, um investimento desta natureza só pode estar associado a uma cidade com uma boa dinâmica económica e à existência de uma elite endinheirada, que contribuiria através de atos evergéticos para suportar as obras de monumentalização da cidade. Relembramos, por isso, que o teatro de Bracara Augusta foi construído em simultâneo com umas termas anexas, facto que implicou a reorganização de todo o setor situado a poente do forum e o arrasamento de vários quarteirões, anteriormente urbanizados. Não temos até ao momento, indícios de financiamento de origem imperial, o que nos leva a crer que estas obras, a que haveria que acrescentar a construção de um anfiteatro ${ }^{43}$, terão sido integralmente financiadas pelas elites municipais e por famílias destacadas, enriquecidas por via da atividade agropecuária, comercial ou artesanal, como aliás é o caso de vários teatros no ocidente romano ${ }^{44}$. Certamente que esta frente cénica, com uma identidade muito própria, transmitia uma mensagem política e propagandística, que devemos associar ao regime imperial e ao poder crescente das elites bracarenses, que procuravam através da construção destes edifícios de prestígio revelar a sua conformidade com Roma, seguramente na esperança de poder com ela obter benefícios de cargos, ou carreiras.

\section{BIBLIOGRAFIA}

BARRESI, Paolo (2000) - Architettura pubblica e munificenza in Asia Minore. Richezza, costruzioni e marmi nelle province anatoliche dell'impero. "MedAnt», 3. Pisa, Roma: Edizioni scientifiche italiane, p 309-368.

\footnotetext{
${ }^{40}$ SOLER, 2012: 218; SEAR, 2006: 22.

${ }^{41}$ SEAR, 2006: 14.

${ }^{42}$ SEAR, 2006: 22.

${ }^{43}$ MARTINS et al., 2012; MORAIS, 2001.

${ }^{44}$ SOLER, 2012: 223-224.
} 
(2002) - Il ruolo delle colonne nel costo degli edifici pubblici. In DE NUCCIO, Marilda; UNGARO, Lucrezia, coord.- I marmi colorati della Roma imperiale. Padua: Marsilio, p. 69-81.

(2010) - I teatri di Aphrodisias e di Niceia: marmi e committenza nell'Asia Minore di età imperiale. In CAMPOREALE, Stefano; DESSALES, Hélène; PIZZO, Antonio, coord. - Arqueología de la Construcción II. Los procesos constructivos en el mundo romano: Italia y provincias orientales. Madrid-Mérida: CSIC, p. 337-350.

DELAINE, Janet (1997) - The baths of Caracalla. A study in the design, construction and economics of large-scale building projects in imperial Rome. Portsmouth: JRA, suppl. 25.

DOMINGO, Javier (2012a) - El coste de la arquitectura: avances, problemas e incertidumbres de una metodología de cálculo: Volúbilis y Dougga. «Archeologia dell'Architectura», XVII. Firenze: All'Insegna del Giglio, p. 144-170.

(2012b) - Los costes de la Arquitectura Romana: el capitólio de Volúbilis (Mauretania Tingitana). «Archeologia Classica», LXIII n.s. II, 2. Roma: «L'Erma» di Bretschneider, p. 381-418.

(2013) - The differences in Roman Construction Costs: The Worker's salary. «Boreas», 36. Munster: Scriptorium, p. 119-143.

DUNCAN-JONES, Richard Phare (1974) - The economy of the Roman Empire. Quantitative studies. New York: Cambridge University Press.

GIACCHERO, Marta (1974) - Edictum Diocletiani et Collegarum de pretiis rerum Venalium. Genova: Istituto di Storia Antica e Scienze Ausiliarie.

MAR, Ricardo; PENSABENE, Patrizio (2010) - Finanziamento dell'edilizia pubblica e calcolo dei costi dei materiali lapidei: il caso del Foro Superiore di Tarraco, In CAMPOREALE, Stefano; DESSALES, Hélene; PIZZO, Antonio, eds. - Arqueología de la Construcción II. Los procesos constructivos en el mundo romano: Italia y provincias orientales. Madrid/Mérida: CSIC, Universitá de Siena, École Normale Supérieure, p. 509-537.

MARTINS, Manuela; RIBEIRO, Jorge; MAGALHÃES, Fernanda (2006) - A arqueologia urbana em Braga e a descoberta do teatro romano de Bracara Augusta. «Forum», 40. Braga: Universidade do Minho, p. 9-30.

MARTINS, Manuela; RIBEIRO, Jorge; MAGALHÃES, Fernanda; BRAGA, Cristina (2012) - Urbanismo e arquitetura de Bracara Augusta. Sociedade, economia e lazer. In MELO, Arnaldo; RIBEIRO, Maria do Carmo Franco, coord. - Evolução da paisagem urbana: sociedade e economia. Braga: Universidade do Minho, CITCEM, p. 29-67.

MARTINS, Manuela; MAR, Ricardo; RIBEIRO, Jorge; MAGALHÃES, Fernanda (2013) - A construção do teatro romano de Bracara Augusta. In MELO, Arnaldo; RIBEIRO, Maria do Carmo Franco, coord. - História da Construção. Arquiteturas e Técnicas Construtivas. Braga: Universidade do Minho, CITCEM/LAMOP, p. 41-76.

MARTINS, Manuela; MAR, Ricardo; RIBEIRO, Jorge; MAGALHÃES, Fernanda; PEÑIN, Raquel (2015) - El teatro romano de Bracara Augusta y la urbanización del noroeste peninsular. «Férvedes», 8. Vilalba (Lugo): Museo de Prehistoria e Arqueoloxía de Vilalba, p. 321-330.

MORAIS, R. (2001) - Breve ensaio sobre o anfiteatro de Bracara Augusta. «Forum», 30. Braga: Universidade do Minho, p. 55-76.

OLIVEIRA, Eduardo Pires de (2001) - A pedra-mãe do convento de Mafra, o «Memorial do Convento» de José Saramago e as colunas da igreja do Santuário do Bom Jesus do Monte. In OLIVEIRA, Eduardo Pires de - Riscar, em Braga, no século XVIII e outros ensaios. Braga: Edições APPACDM Distrital de Braga, p. 95-102.

PEGORETTI, Giovanni (1869) - Manuale pratico per l'estimazione dei lavori architettonici, stradali, idraulici e di fortificazione per uso degli ingegneri ed architetti. Milano. 
PRISSET, Jean-Luc (2008) - Les besoins en matériaux, les contraintes d'approvisionnement et la durée d'un chantier de construction. Réflexions à partir du portique Nord de Saint-Romain-en-Gal. In CAMPOREALE, Stefano; DESSALES, Hélène; PIZZO, Antonio, coord. - Arqueología de la Construcción I. Los procesos constructivos en el mundo romano: Italia y provincias occidentales. Madrid-Mérida: CSIC, p. 125-139.

RIBEIRO, Jorge (2013) - Arquitectura romana em Bracara Augusta. Uma análise das técnicas edilícias. Porto: Afrontamento, CITCEM.

SEAR, Franck (2006) - Roman theatres. An architectural study. New York: Oxford University Press.

SOLER, Begoña (2012) - Planificación, producción y costo del programa marmóreo del teatro romano de Cartagena. In GARCÍA - ENTERO, Virginia, coord. - El marmor en Hispania: explotación, uso $y$ difusión en época romana. Madrid: UNED, p. 193-228. 


\section{INTERPRETAR, CONSERVAR, VALORIZAR A RUIINA. REFLEXÕES EM CONTEXTO ACADÉMICO}

PEDRO ALARCÃO*

Os frutos da colaboração entre arqueólogos e arquitectos são hoje realidade genericamente aceite e tinham sido já comprovados, de forma que se pretende cada vez mais transdisciplinar, por muitos dos que participaram no Encontro CITCEM Construir, Navegar (Re)Usar o Douro da Antiguidade.

Tal colaboração passa, sobretudo, e no que aos arquitectos diz respeito, pelo uso do desenho como método e instrumento de concepção, um desenho capaz de determinar a lógica compositiva do edifício (o seu traçado, distribuição entre partes e proporção), bem como a sua lógica de materialização (o seu sistema estrutural e técnica construtiva).

Mas este instrumento de concepção pode também ser uma ferramenta de análise, agora em sentido inverso, da ruína ao construído, e ninguém está em melhores condições para empreender tal tarefa, do que o arquitecto, utilizando o que subsiste, para determinar o que falta.

Se este entendimento começa a ser aceite em certos meios profissionais, mais ligados à intervenção e gestão em contexto arqueológico, é premente levar estas temáticas e reflexões para o ambiente académico, por forma a sensibilizar e formar os estudantes e recém-licenciados em Arquitectura, seja na interpretação, na conservação ou na valorização dos vestígios escavados, tarefa que temos vindo a empreender em diversos níveis de ensino da FAUP, e cujos resultados aqui partilhamos.

*CEAU-FAUP. p.alarcao@arq.up.pt. 
A interpretação de um sítio arqueológico pode realizar-se a partir de um edifício para a cidade, tentando determinar ou confirmar o seu traçado viário (nomeadamente o recurso uma modulação concebida a partir do actus quadratus), compreender o seu processo de transformação, apontar novas hipóteses para a composição de alguns dos seus edifícios e até mesmo identificar novas estruturas e edifícios. Tal aconteceu em Tongobriga, onde se apontou uma nova hipótese para o porticado da praça do fórum e a eventual existência de um teatro ou até mesmo de um anfiteatro, ambos equidistantes entre si e o forum, constituindo um interessante centro cívico; hipóteses sempre dependentes de sondagens e sujeitas a confirmação pela arqueologia (Figs. 1 a 3).

Fig. 1.

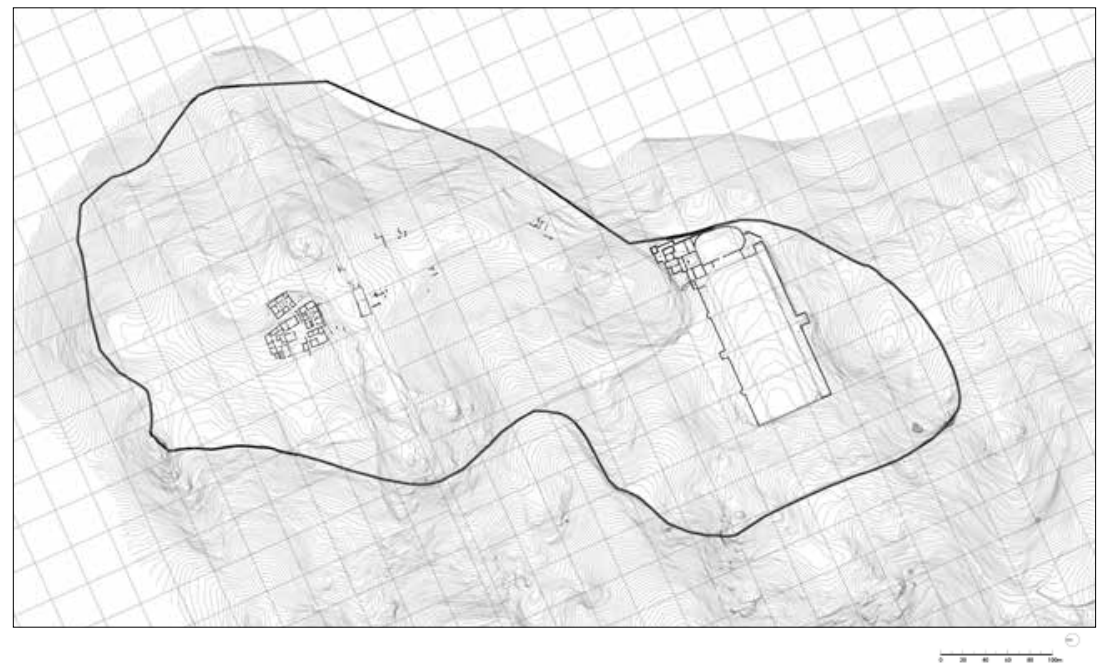

(2011).

Fig. 2.

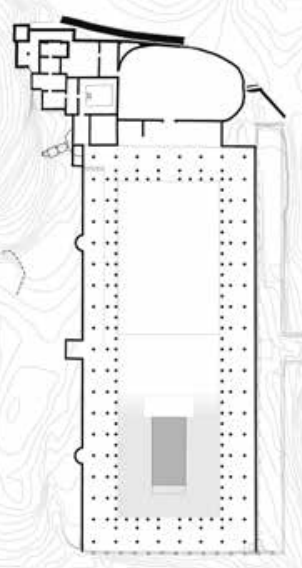

Charles Rocha

(2011). 


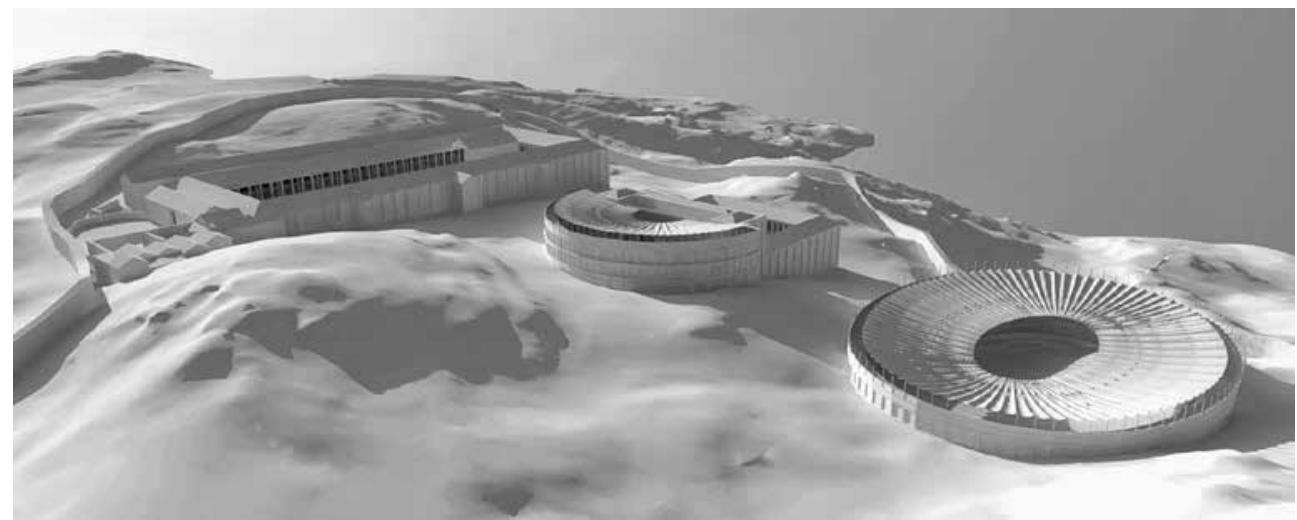

Fig. 3. Tongobriga. Charles Rocha (2011).

Mas a interpretação pode igualmente surgir de um edifício bem conhecido, embora não orientado segundo o alinhamento do restante traçado urbano, determinando a medida utilizada na sua concepção, o pes romanus, para intuir os elementos desaparecidos da cidade, agregando todos os vestígios escavados e dispersos, por forma a identificar um hipotético traçado viário quadriculado; assim como estender-se à interpretação do território, nomeadamente na identificação da centuriação, como aconteceu em Chaves, antiga aqua flavia. Nos casos em que tal acontece, a confirmação da grelha à escala territorial, é um magnífico indício da sua justeza à escala urbana e arquitectónica (Figs. 4 e 5).

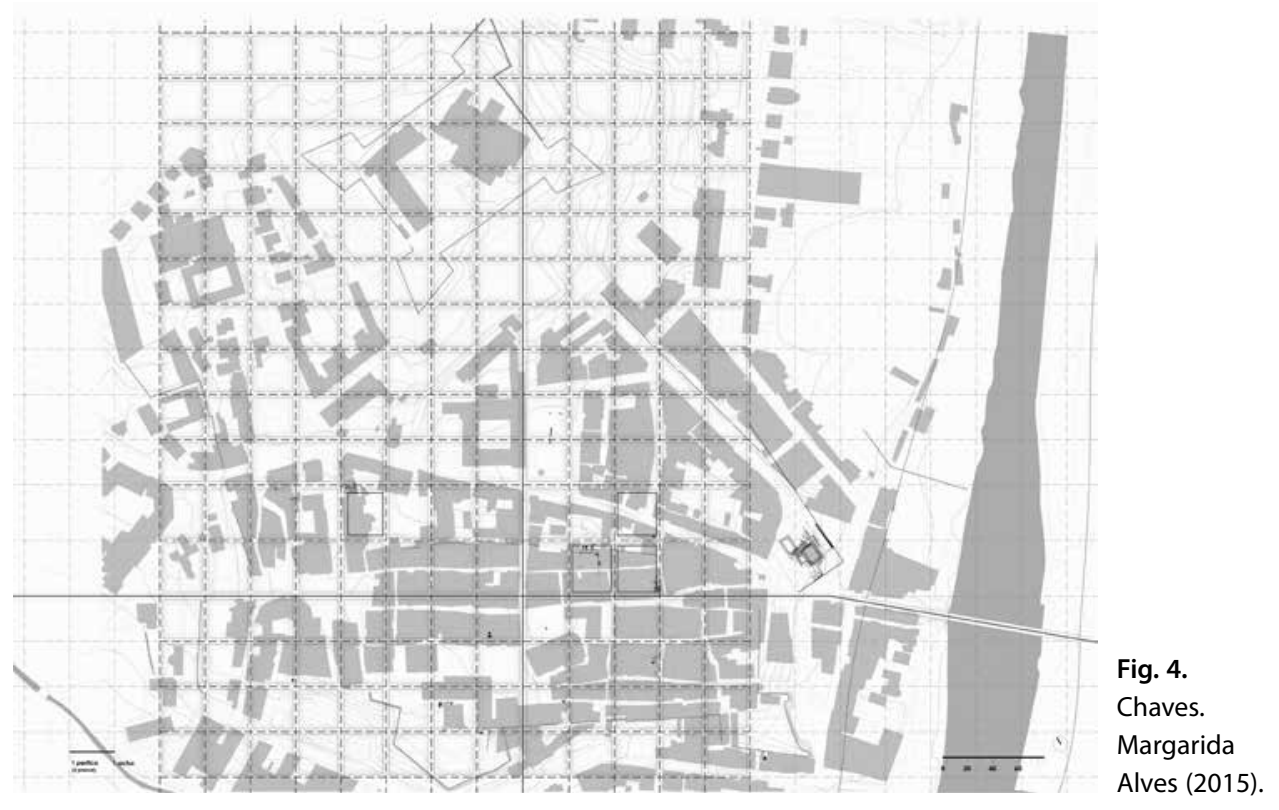




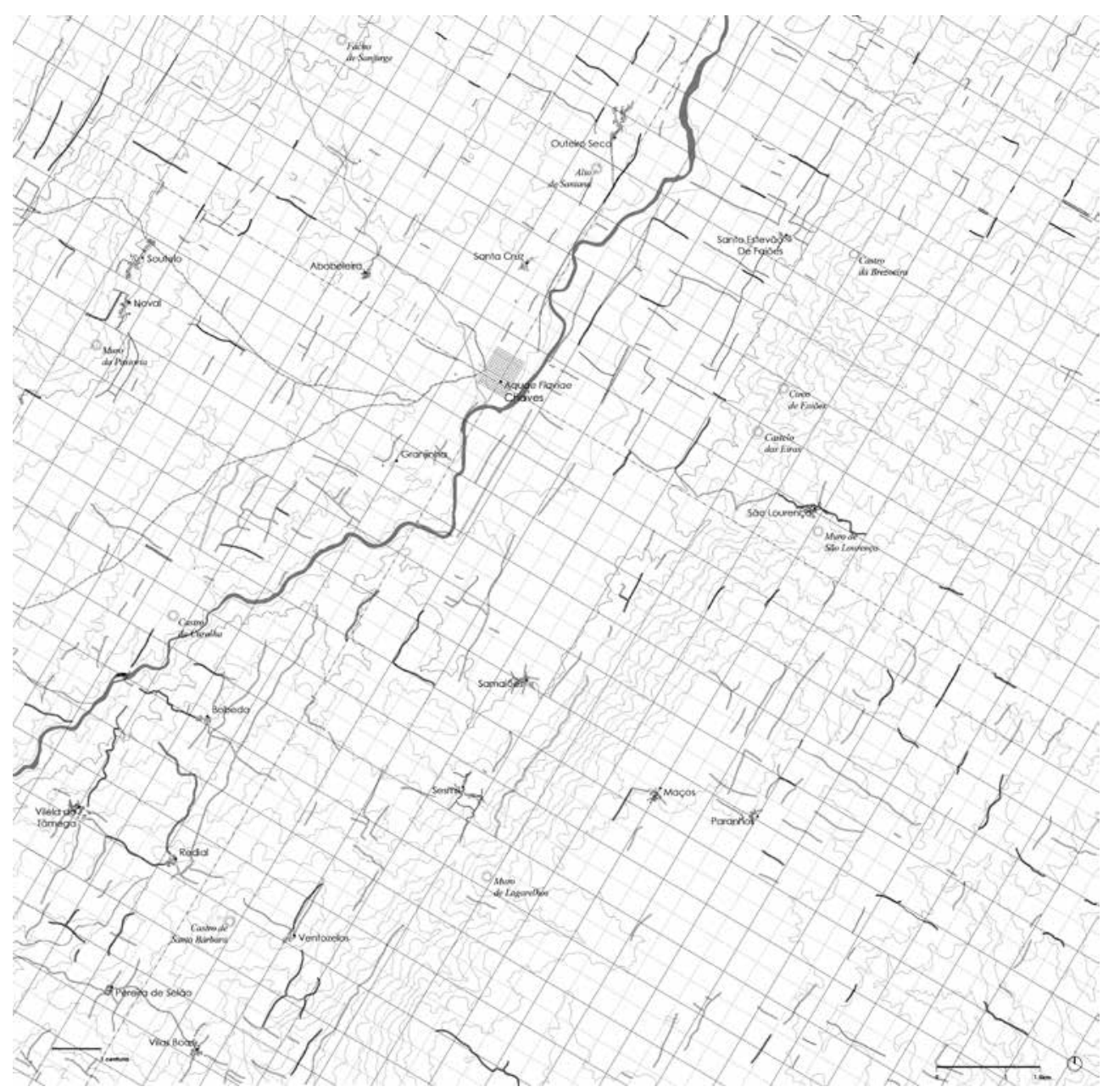

Fig. 5. Chaves. Margarida Alves (2015).

Todas estas interpretações realizadas pelos arquitectos, constituem-se como hipóteses colocadas ao serviço da arqueologia, para serem validadas ou refutadas, em função dos dados disponíveis a cada momento.

Posteriormente, a reflexão passa pela necessidade de conservação dos vestígios arqueológicos. Desde logo pela protecção de muros e pavimentos e, nesta matéria, é importante ter em conta que qualquer acção de protecção, mesmo de impermeabilização de estruturas, por mínima que seja, é uma operação de reconstrução, porque adiciona matéria à estrutura intervencionada; sendo, em sentido mais amplo, uma operação de valorização. 
Abordam-se igualmente as metodologias de protecção mais alargada, quando tais operações implicam intervenções arquitectónicas, como a criação de novas superfícies pavimentadas, o alteamento de muros, a protecção de estruturas subterrâneas a cobrir, ou a necessidade de reconstituir estruturas, para promover acções de anastilose ou reconstituições parciais; todas estas acções empreendidas com a necessária protecção das estruturas originais e o debate sobre a decisão por uma linguagem arquitectónica mimética ou identificada.

A conservação das estruturas arqueológicas implica em muitas situações a construção de um abrigo, uma cobertura e, em alguns casos, a necessidade de estender a protecção a planos verticais, configurando uma espécie de contentor.

Essa cobertura pode ser abstracta, tendo como único intuito a protecção dos vestígios e, nesse caso, apenas cumpre a função de conservação da ruína; o que não implica o descuido do seu desenho e do seu processo construtivo, nomeadamente a sua compatibilização com as estruturas escavadas, bem como o seu necessário enquadramento com a envolvente (Fig. 6).

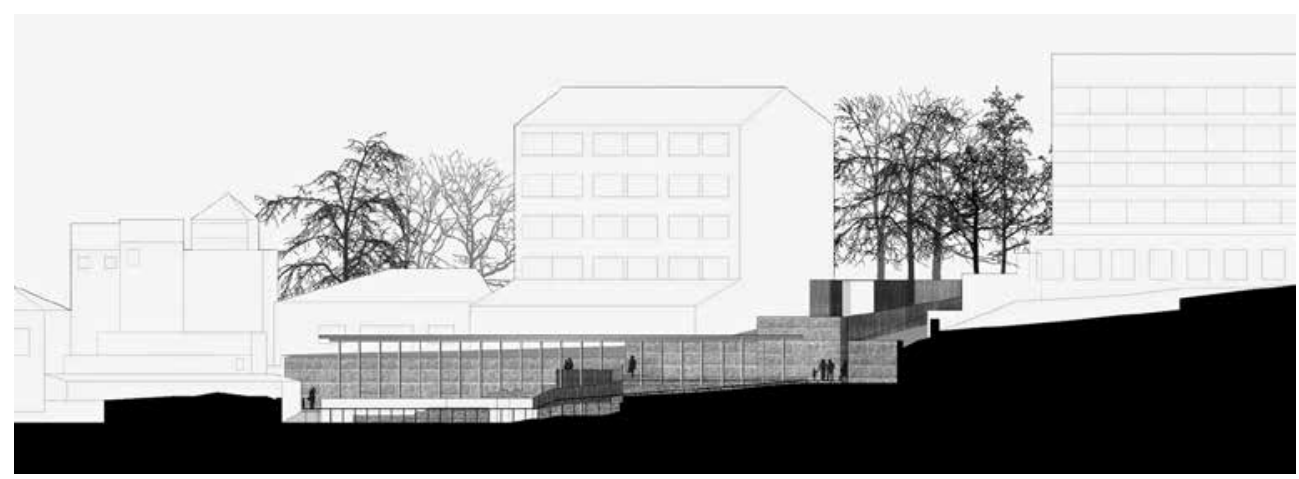

Fig. 6. Complexo edificado das Carvalheiras, Braga. Ana Luísa Sá (2012-2013).

Mas a cobertura pode também ser evocativa e, nesse caso, para além da conservação da ruína, contribui igualmente para a sua valorização; pois é através da sua capacidade evocativa que podemos garantir uma melhor compreensão dos vestígios arqueológicos, sem recurso a reconstituições directamente realizadas sobre eles.

Os níveis de evocação de uma cobertura podem ser variados, desde a possibilidade de dar indicação de estruturas murárias desaparecidas, da escala integral ou parcial do espaço interior ou da sua compartimentação, da relação entre luz e sombra existente na arquitectura evocada, das formas dos seus tectos e coberturas exteriores, etc. (Fig. 7). 

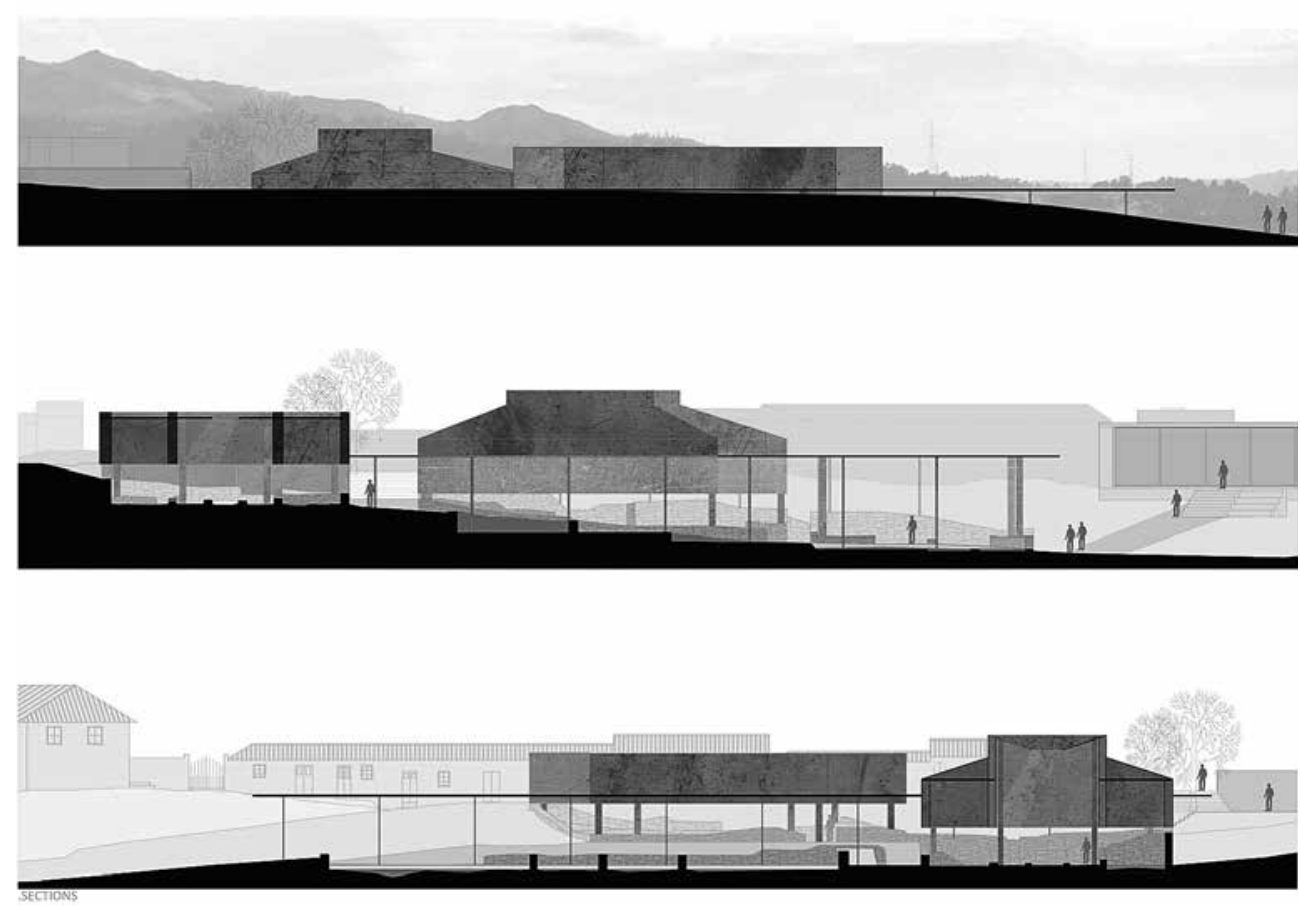

Fig. 7. Área Habitacional, Tongobriga. Margarida Leão (2012).

Se as coberturas têm como principal função proteger os vestígios exumados, em alguns casos as mesmas podem ser praticáveis, criando novos pavimentos e garantindo excelentes acessos às arquitecturas e ambientes evocados (Figs. 8 e 9).

Fig. 8.

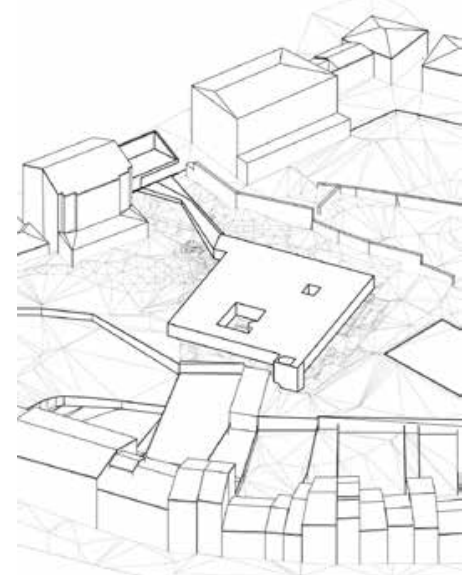

Complexo edificado das Carvalheiras, 


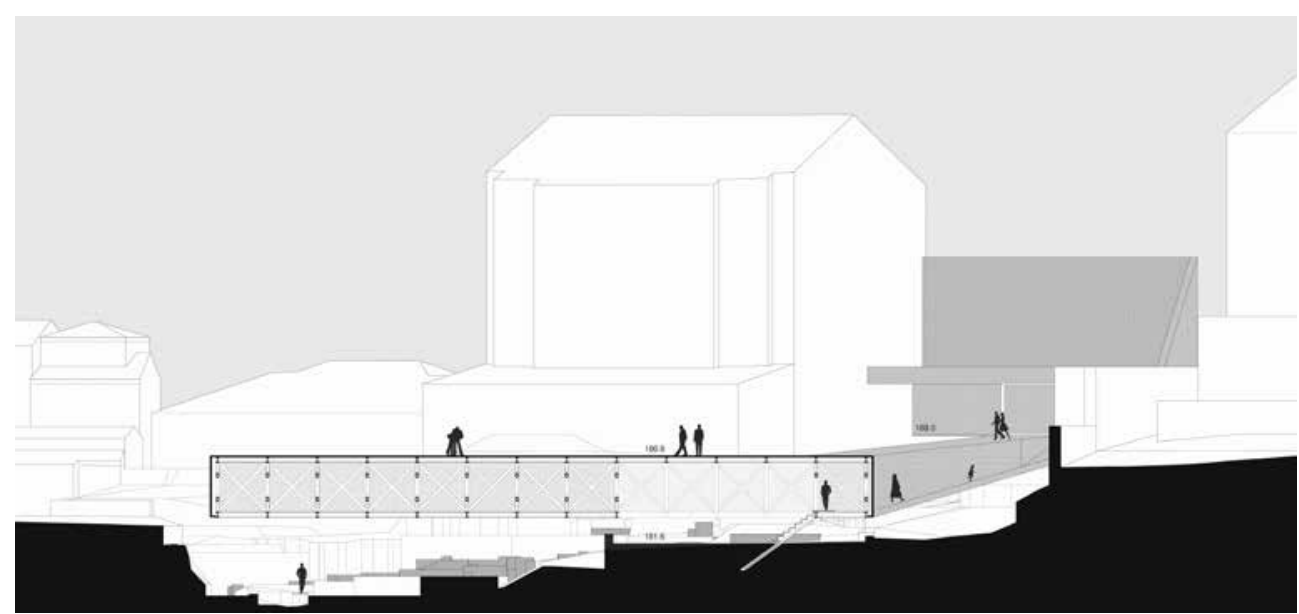

Fig. 9. Complexo edificado das Carvalheiras, Braga. Pedro Cruz (2012-2013).

Respondendo às solicitações da cidade actual, os novos mecanismos para garantir a fruição pública da ruína e aumentar os seus níveis de compreensão, são também oportunidades para assegurar uma rica e equilibrada experiência de passagem para o mundo Antigo (Figs. 10 e 11).

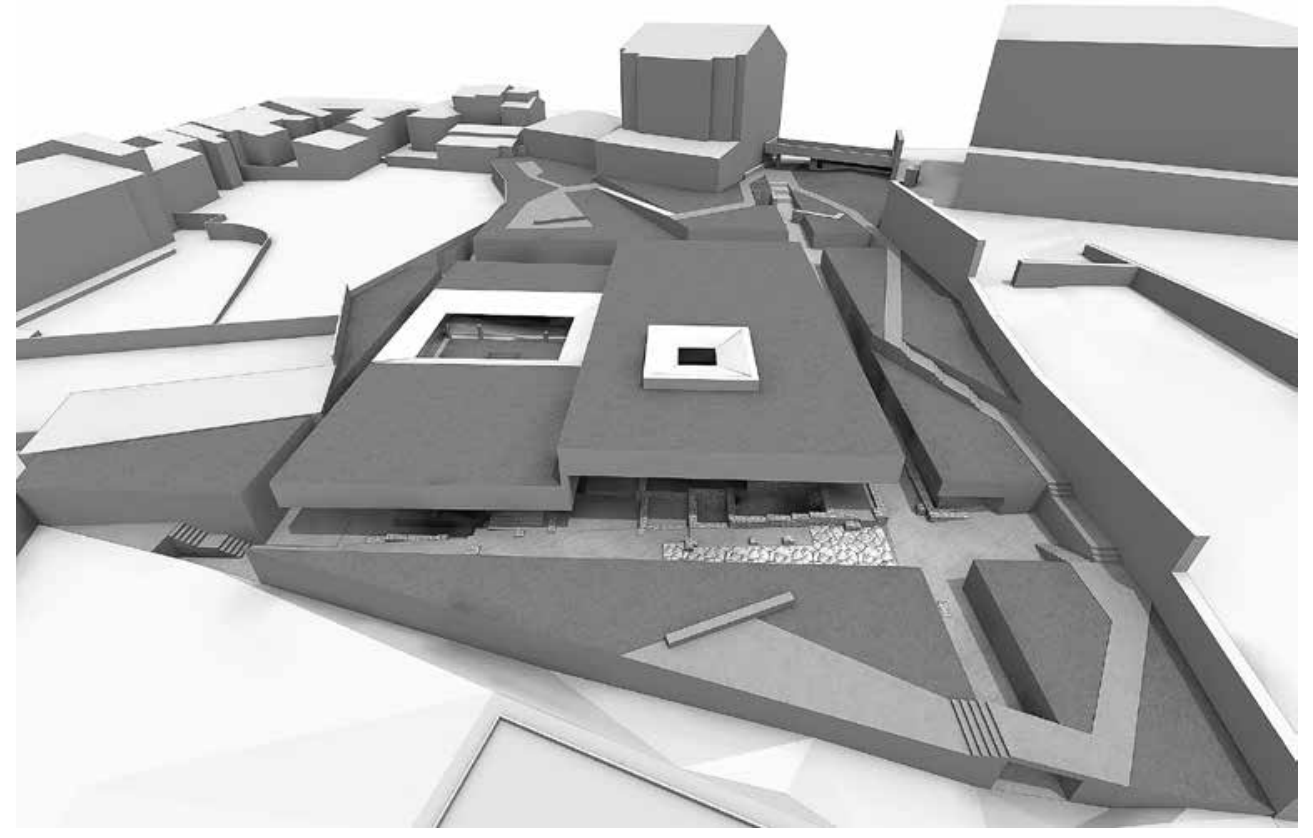

Fig. 10. Complexo edificado das Carvalheiras, Braga. Carlos Machado e Moura (2012-2013). 


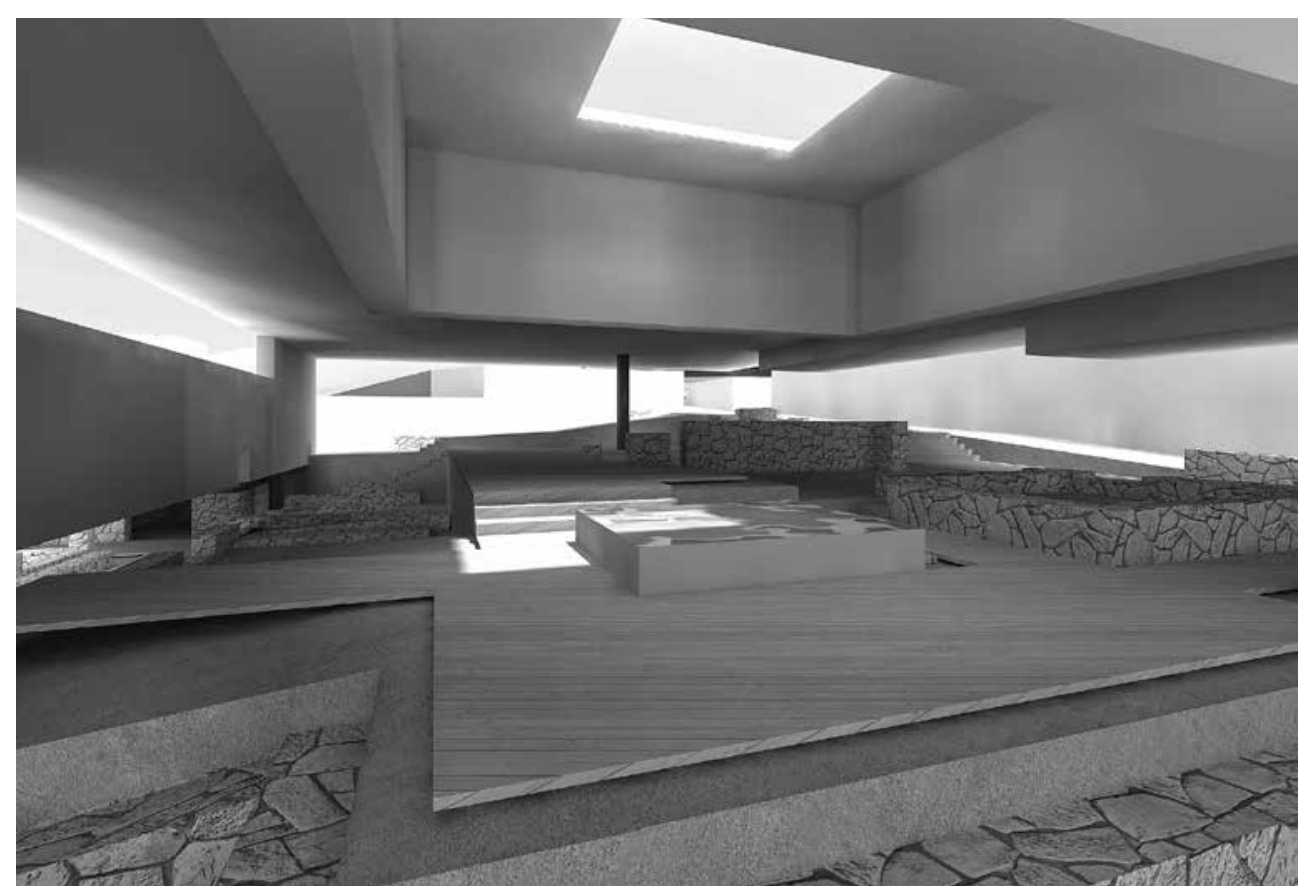

Fig. 11. Complexo edificado das Carvalheiras, Braga. Carlos Machado e Moura (2012-2013).

Algumas estruturas arqueológicas não necessitam de cobertura, desde logo as que não apresentam elementos com necessidade de preservação, ou, de um modo geral, quando se tratam de fragmentos de arquitecturas que nunca tiveram cobertura.

Uns desses casos são os edifícios de espectáculo, como os teatros ou anfiteatros, edifícios que melhores condições têm para se reutilizar, naturalmente mantendo a sua função original, dando cumprimento à Carta de Verona e à Recomendação de Segesta.

Essas acções de valorização, sempre entendidas igualmente como protecção de estruturas, desde que devidamente acauteladas, são formas de aumentar os níveis de inteligibilidade dos vestígios, seja pela reconstituição de elementos essenciais da composição da sua cavea ou do seu corpo cénico, de uma parte da sua volumetria desaparecida, dos seus acessos originais, etc. A reconstituição de elementos de um corpo cénico pode, por exemplo, ajudar a explicar a tipologia do teatro romano e ao mesmo tempo ajudar a enquadrar ou minimizar uma envolvente difícil. Uma reconstituição parcial de uma cavea, ou de partes fundamentais para a sua compreensão, para além de naturalmente permitir a sua fruição e uso, aumenta a percepção do visitante. De igual modo, alguma estrutura nova que seja necessário criar, como uma recepção ao visitante ou um pequeno centro interpretativo ou expositivo, pode contribuir, desde que devidamente articulada, como mais um auxiliar de compreensão da ruína (Fig. 12). 


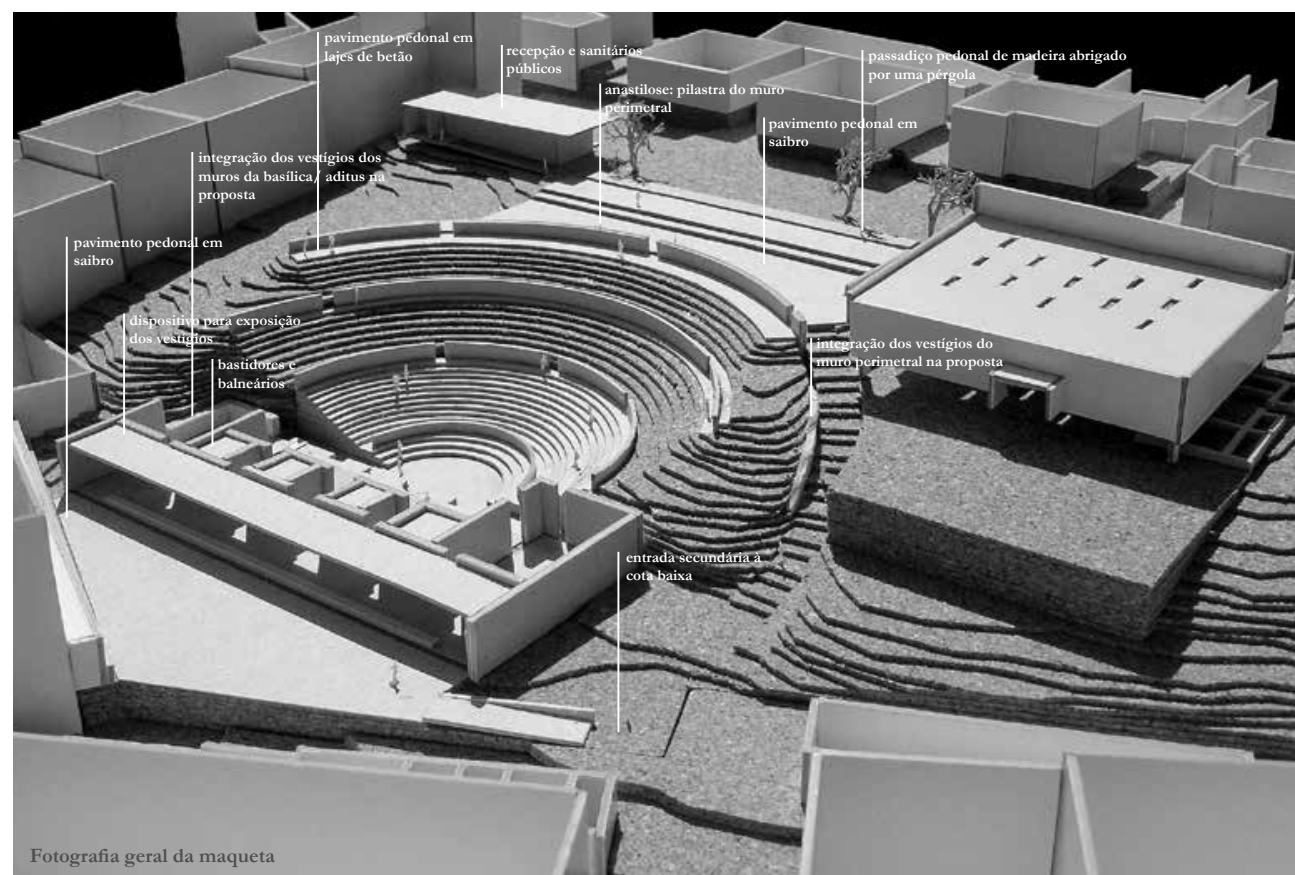

Fig. 12. Teatro Romano do Alto da Cividade, Braga. Mariana Sá (2011-2012).

Outras estruturas arqueológicas não necessitam de cobertura, porque estão elas já, em resultado do crescimento urbano que as envolveu, cobertas por edificação contemporânea. E nesse caso, resolvida que está a primeira necessidade da sua conservação, é necessário tratar as referidas estruturas e compatibilizar as mesmas com a fruição pública pretendida; bem como compatibilizar os espaços agora tratados, com o contentor contemporâneo herdado, tenha a intervenção como objectivo apenas a fruição pública ou a reabilitação arquitectónica do espaço, com introdução de uma nova função (Fig. 13).
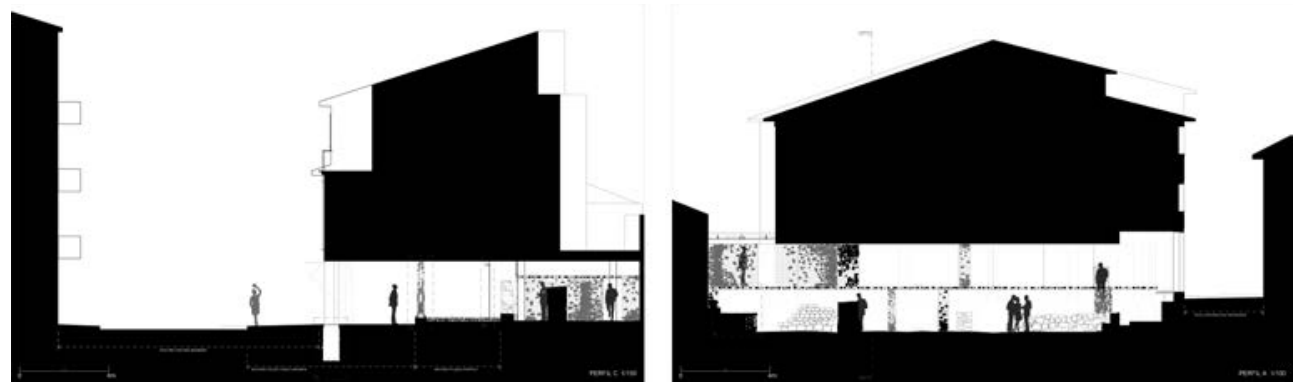

Fig. 13. Complexo edificado Rua Frei Caetano Brandão, Braga. António Pinto (2013-2014). 
A interpretação e a consequente reconstituição da ruína, se não deve ter qualquer limite no desenho e na realização de modelos, sejam físicos ou virtuais, deve ser muito ponderada, no caso de se pretender implementar a sua materialização.

E as razões são várias: em primeiro lugar é necessário pensar que o conhecimento das arquitecturas fragmentadas que estamos a interpretar está em permanente desenvolvimento, em função de novas escavações e novos dados, e a correcção de uma interpretação materializada pode, pura e simplesmente, já não ser possível; em segundo lugar, temos que ter em consideração a importância da ruína, importância essa que deriva justamente do facto de se ter tornado precisamente numa ruína, perdendo em grande parte os seus valores de firmitas e de utilitas, mantendo o seu valor de venustas, agora muito sobrevalorizado, em resultado do seu progressivo desaparecimento, enquanto arquitectura.

Sobretudo por estas razões, se opta, na maioria dos casos, por promover reconstituições bastante parciais da ruína e se acautela o estado de conservação das estruturas originais.

Para suprir essa limitação, da materialização das interpretações que vão sendo realizadas, implementam-se dispositivos para comunicação das mesmas, através dos meios mais comuns de divulgação, nomeadamente em papel e em suporte virtual, como referimos. Os primeiros são disponibilizados em brochuras ou catálogos e, preferencialmente, em painéis informativos e sinalética vária; sendo os segundos divulgados por meios informáticos de visionamento, em estruturas de acolhimento ou por consulta on-line.

Outros meios de comunicação, que podemos considerar de engenhosos mecanismos de comunicação interpretativa, podem ser a combinação, in situ, da interpretação desenhada e do próprio objecto da interpretação (Figs. 14 e 15).

Finalmente, recorremos a Alberto Ustárroz, como repetidamente gostamos de fazer, para salientar a principal Lição que os arquitectos podem retirar das ruínas, seja em contexto profissional ou académico.

Como podem as ruínas ajudar a construir o presente? As ruínas devolvemnos o que lhes damos, o que lhes perguntamos desde o presente, transformado, acrescentado com a sua proposta radical, isto é, a sua mensagem de essencialidade ${ }^{1}$.

${ }^{1}$ USTÁRROZ, 1997: 286. 


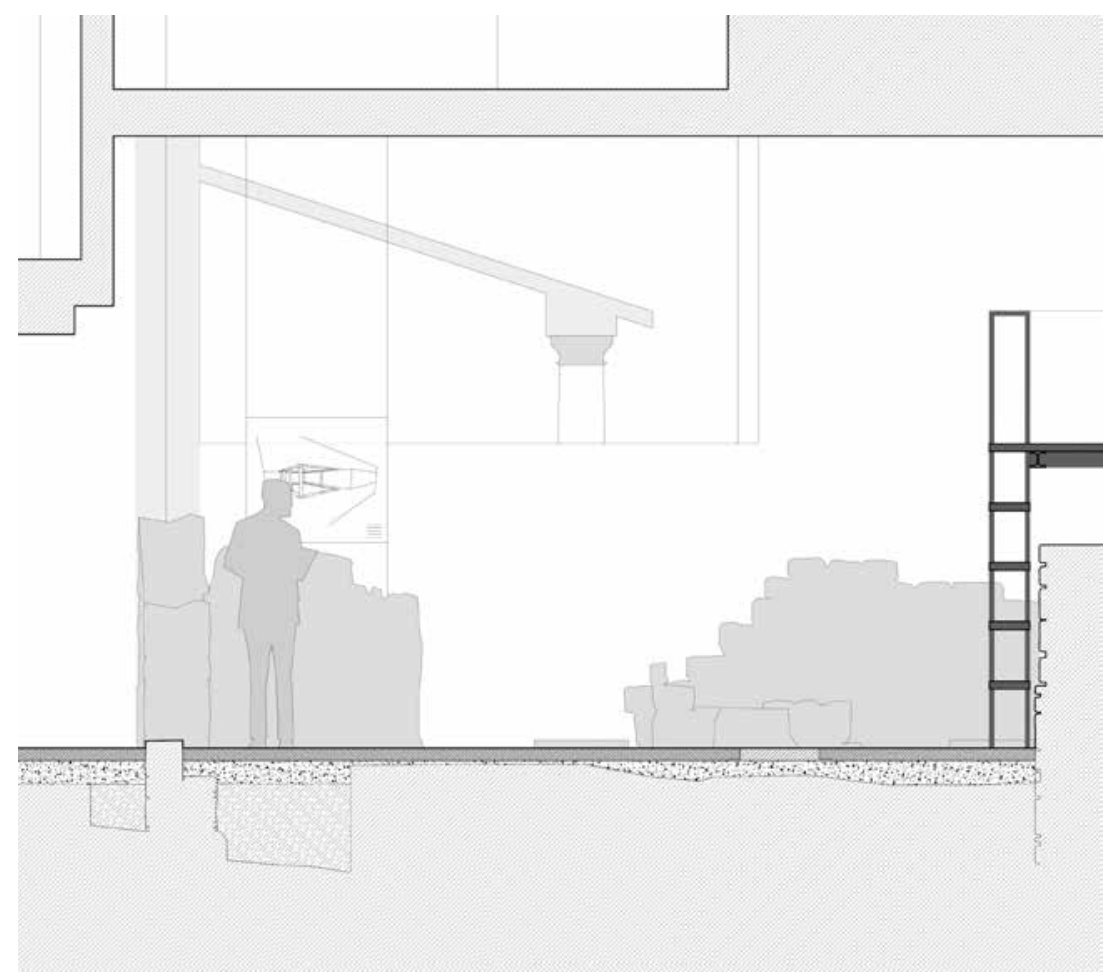

Fig. 14.

Complexo edificado Rua Frei Caetano Brandão, Braga. Charles Rocha (2013-2014).

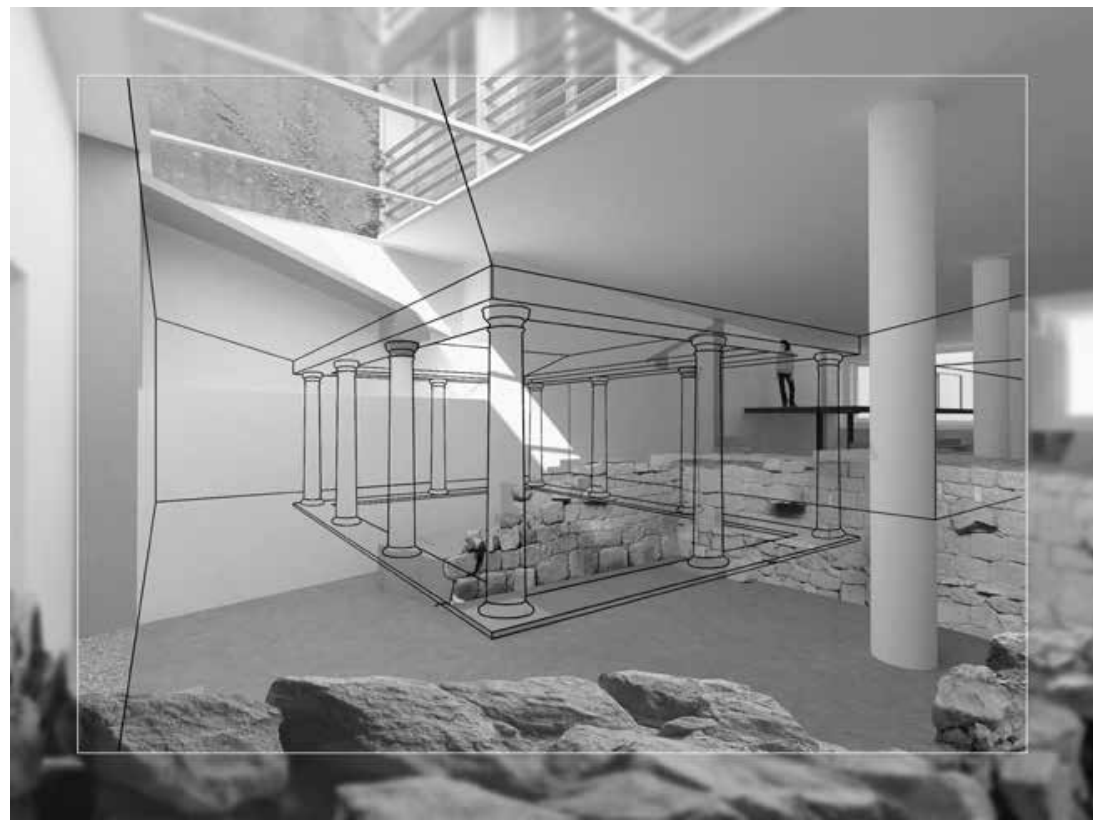

Fig. 15.

Complexo edificado Rua Frei Caetano Brandão, Braga. Charles Rocha (2013-2014). 


\section{REFLEXÕES APRESENTADAS}

1. Dissertação de Mestrado Integrado em Arquitectura - FAUP

- Charles Rocha. «Centro cívico de Tongobriga. Contributos para a sua reconstituição conjectural», 2011

- Margarida Leão. «Cidade Romana de Tongobriga. Contributos para a sua conservação e inteligibilidade», 2012

- Margarida Alves. «Aquae Flaviae: a ruína como imagem da cidade», 2015

- Elsa Pinto. «A Arquitectura como Instrumento de Compreensão, Consolidação e Valorização da Ruína. O caso do Monte Mozinho, Penafiel» (em curso)

2. Curso de Estudos Avançados em Património Arquitectónico (CEAPA-FAUP) - UC Metodologias de Projecto - Tema 1 (Património Arqueológico)

2011-2012 - Carlos Graça, Mariana Carvalho, Mariana Sá

2012-2013 - Ana Luísa Sá, Carlos Machado e Moura, Fernando Barros, Pedro Cruz

2013-2014 - António Pinto, Charles Rocha, José António Lopes, Luísa Capitão 2015-2016 - Catarina Azevedo, Marcos Veiga, Sofia Gaspar

\section{BIBLIOGRAFIA}

ADAM, Jean-Pierre (1989) - La constrution Romaine: matériaux et techniques. 2a ed. Paris: Grands Manuels Picard.

ALARCÃO, Pedro (2009) - Construir na ruína. A propósito da cidade romanizada de Conimbriga. Porto: Faculdade de Arquitectura da Universidade do Porto. Tese de Doutoramento (policopiada). coord. (2014) - Catálogo de Exposição Intervenção arquitectónica em contexto arqueológico. Propostas e desafios para a cidade de Braga. Porto: FAUP publicações.

DIAS, Lino Tavares; ALARCÃO, Pedro, coord. (2011) - Interpretar a Ruína: contribuições entre campos disciplinares. Actas do Seminário Internacional de Arquitectura e Arqueologia. FAUP, 2008. Porto: FAUP Publicações.

JONES, Mark Wilson (2003) - Principles of Roman Architecture. London: Yale University Press.

ROCHA, Charles; TAVARES DIAS, Lino; ALARCÃO, Pedro (2014) - Tongobriga. Reflexões sobre o seu desenho urbano. Porto: CITCEM e Edições Afrontamento.

USTÁRROZ, Alberto (1997) - La Lección de las Ruinas: presencia del pensamiento griego y romano en la arquitectura. Barcelona: Fundación Caja de Arquitectos. (Arquíthesis, n. ${ }^{\circ}$ 1). 


\title{
O MUNDO RURAL ROMANO \\ NO VALE DO DOURO
}

\author{
PEDRO PEREIRA*
}

A série de eventos que viria a culminar com a transformação da Península Ibérica num território romano é importante para compreendermos como é que se processa a apropriação do território rural do Douro.

O final da segunda guerra púnica, em 201 a. C., marca o destino do território peninsular. Roma, avaliando a riqueza dos territórios dominados anteriormente por Cartago, decide estabelecer-se na zona. Inicialmente discreta, esta presença será marcada por uma série de avanços, de índole militar, económica e cultural, dominando cada vez parcelas maiores do território ibérico, seja através da conquista militar seja através de uma série de alianças ou pactos com os povos autóctones.

O território peninsular anterior à chegada de Roma, os povos que o habitam, a sua organização e hierarquias são-nos largamente desconhecidos. Apenas alguns reflexos destas culturas chegarão a nós, em grande parte devido aos contactos com povos exógenos ao território e que os descrevem, como sucede com as obras de Plínio ${ }^{1}$ ou Estrabão ${ }^{2}$.

A cultura e arquitectura romanas seguem, um pouco por todo o Mediterrâneo, um modelo mais ou menos constante, revelando, certamente, algumas diacronias regionais, tais como a construção de estruturas de aquecimento em várias divi-

\footnotetext{
* Arqueólogo. Investigador do CITCEM (FLUP/FCT).

${ }^{1}$ Plínio, Naturalis Historia. Livro XV.

${ }^{2}$ Estrabão, Geographia, III, 3, 3.
} 
sões em territórios mais frios ou a utilização de telhados em lamelas em xisto em territórios onde a argila era um bem menos comum. Esta questão das diacronias regionais está intrinsecamente ligada à questão da romanização, como se processa e, sobretudo, como é que uma cultura indígena é afectada por uma cultura exógena, ainda que mais avançada tecnicamente. Embora esta temática seja já discutida para outros territórios do Império Romano ${ }^{3}$, é extremamente interessante observar como é que se processou num território de fronteira, onde ainda hoje as diacronias micro regionais se sentem, sejam através de um processo de assimilação cultural, seja de forma natural.

O mundo rural romano no Vale do Douro continua a escapar-nos em grande parte. Se é verdade que nas últimas décadas têm vindo a ser feitas novas descobertas que acabam por deitar por terra muitos preconceitos da historiografia tradicional, temos que ter em conta que sabemos muito pouco sobre como se organizou o território, sendo que grande parte dos projectos que têm vindo a ser desenvolvidos no Vale do Douro acabam, muitas vezes, por ter apenas um objectivo local ou micro-regional ou de âmbito cronológico restricto, que impede uma compreensão mais lata de como se desenvolve a presença humana e, neste caso, romana no território.

Ao longo do século XIX, com a disseminação do conceito de nacionalismo e de orgulho nacional, cresce também o interesse com a história de cada nação, e em alguns casos, região, concomitantemente, com os dados que escapam, em grande parte, aos documentos historiográficos: os dados arqueológicos. Serão vários os interessados, o que podemos hoje em dia apelidar de pré ou proto arqueólogos, provenientes das mais diversas áreas de estudos, que irão começar com a prática da arqueologia no Douro, a recolher elementos e a escrever sobre a região. Será com Carlos Teixeira, em 1939, quando este visita o Alto da Fonte do Milho, em Canelas (Peso da Régua) e publica materiais e estruturas tornadas visíveis por arroteamentos na zona ${ }^{4}$, ou ainda em 1903, com a escavação da Quinta Nova de Nossa Senhora da Ribeira, em Tralhariz (Carrazeda de Ansiães) por Ricardo Severo ${ }^{5}$, que se começará a abordar a questão da ocupação rural romana, embora ainda de uma forma muito incipiente. A estes homens de letras podemos adicionar outros, como o célebre Abade de Baçal, Rocha Peixoto, Leite de Vasconcellos ou Fernando de Russel Cortez.

Devemos, antes de mais, referir que até muito recentemente, durante a escavação de uma estrutura agrícola romana, os investigadores centravam os seus esforços e estudo nas estruturas nobres, como os hipogeus de termas, salas com mosaicos, etc.

\footnotetext{
${ }^{3}$ MOMMSEN, 2004.

${ }^{4}$ TEIXEIRA, 1939.

${ }^{5}$ SEVERO, 1903.
} 


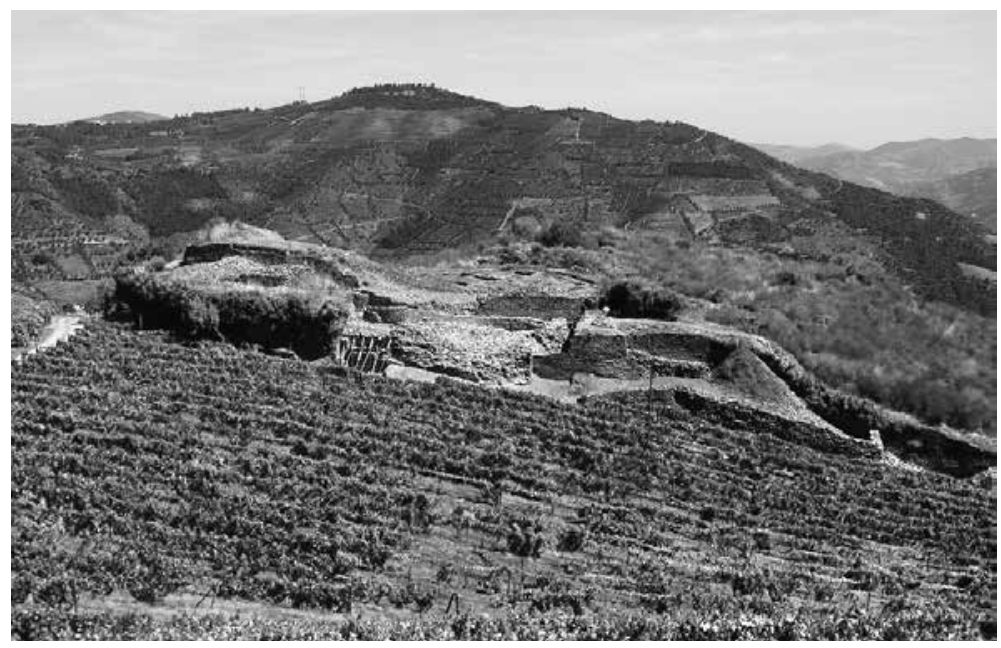

Fig. 1.

Vista do Alto da Fonte do Milho (Canelas,

Peso da Régua) durante a intervenção da DRC-N, 201. Cliché do autor.

Em suma, na pars urbana, a zona residencial do dominus na villa. No entanto, a maioria das informações que nos poderão ajudar a compreender como é que se organizou o mundo agrícola romano provêm das zonas menos sumptuosas, as pars fructaria e pars agricola, o campo, as zonas de transformação, armazenamento e residência da maioria dos trabalhadores de uma exploração agrícola no período romano.

Na década de 1940, Fernando de Russel Cortez, topógrafo de formação e interessado em Arqueologia desde cedo ${ }^{6}$, recebe uma bolsa do Instituto do Vinho do Porto para iniciar um estudo sobre a ocupação antiga do Douro. Na sua correspondência com o director do instituto podemos observar que Cortez identifica uma série de sítios de interesse e propõe-se a realizar escavações no Alto da Fonte do Milho. Será aqui que será descoberta a primeira estrutura de lagar de vinho romano no Vale do Douro ${ }^{7}$. Cortez decide, intencionalmente, não partir em busca do «palácio romano» ${ }^{8}$. Em 2010, a área é re-escavada e musealizada por uma equipa liderada por Javier Lazarrabal Galarza num projecto da Direcção Regional da Cultura do Norte.

Infelizmente, entre a década de 1950 e 1980 poucos serão os avanços na investigação arqueológica sobre a romanização no Vale do Douro. A centralização de fundos na área do Vale do Tejo iniciada por Manuel Heleno na década de $1960^{9}$ irá continuar ao longo dessas décadas, sendo que apenas projectos de investigação extremamente

\footnotetext{
${ }^{6}$ Realiza, por exemplo, escavações da Cividade de Bagunte, em Vila do Conde, em 1944.

${ }^{7}$ CORTEZ, 1948a.

${ }^{8}$ Descrição da área que Carlos Teixeira visita, em 1909, na cartografia da DGMN.

${ }^{9}$ PEREIRA, 2016.
} 
Fig. 2.

Sítio de Olival

dos Telhões

(Almendra, Vila Nova

de Foz Côa), 1998.

Cliché de Susana Cosme.

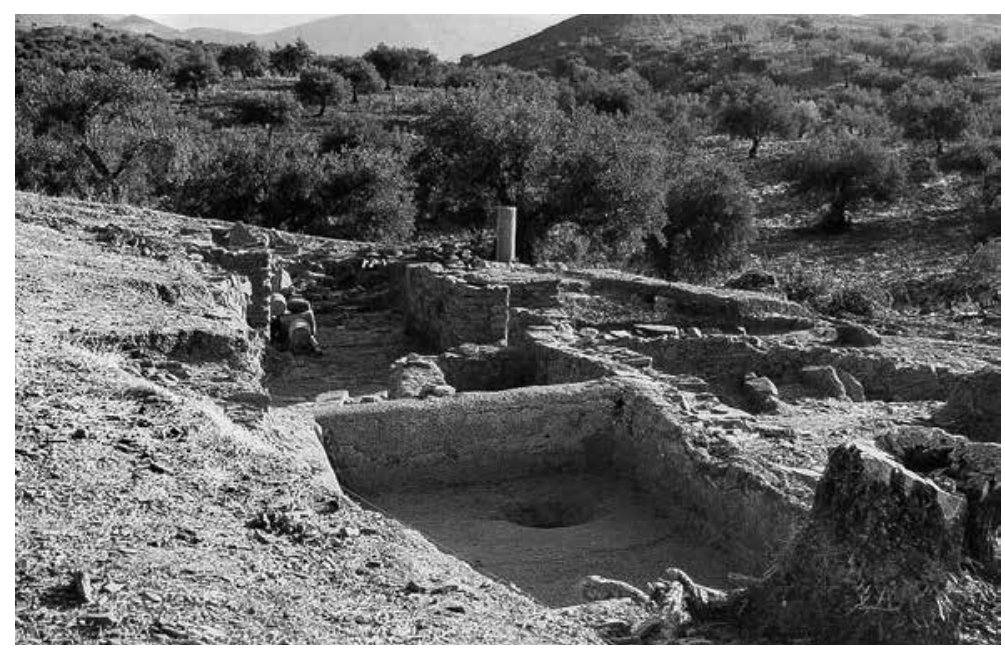

localizados e, muitas vezes, sem uma orientação científica formal, serão realizados na bacia do Douro português.

Os trabalhos desenvolvidos pelo Grupo de Estudos de História do Vinho e da Vinha no Vale do Douro foram também inovadores para a identificação de estabelecimentos agrícolas romanos e compreender a realidade do campo nesse momento ${ }^{10}$.

O projecto desenvolvido por Susana Cosme em Olival dos Telhões, Almendra (Vila Nova de Foz Côa) ${ }^{11}$ na década de 1990 e inícios de 2000, permitiu a identificação de uma estrutura de prensa de vinho e uma série de estruturas adjacentes de, muito provavelmente, uma exploração agrícola de maiores dimensões. Ao mesmo tempo, o trabalho académico em que esta escavação se inseriu permitiu a identificação, através de prospecção, de dezenas de sítios de cronologia romana entre as bacias do Côa e Douro.

Todavia, o trabalho realizado pelo GEHVID na identificação, registo e valorização de estruturas de exploração agrícola de época romana foi mais abrangente, com prospecções amplas na zona do Alto Douro, centradas em lagares escavados na rocha, e na zona de Alijó ${ }^{12}$.

O trabalho que tem vindo a ser desenvolvido nos concelhos de Vila Nova de Foz Côa e Mêda por António de Sá Coixão, Tony Silvino e as suas equipas são talvez o melhor exemplo para a compreensão do mundo rural romano no território do Douro português. Ao longo das últimas três décadas, esta equipa, com a qual temos

\footnotetext{
${ }^{10}$ Este centro cria também uma importante plataforma de divulgação sobre a investigação no Vale do Douro, a revista «Douro - estudos e documentos».

${ }^{11}$ COSME, 2002.

12 ALMEIDA, 2006.
} 


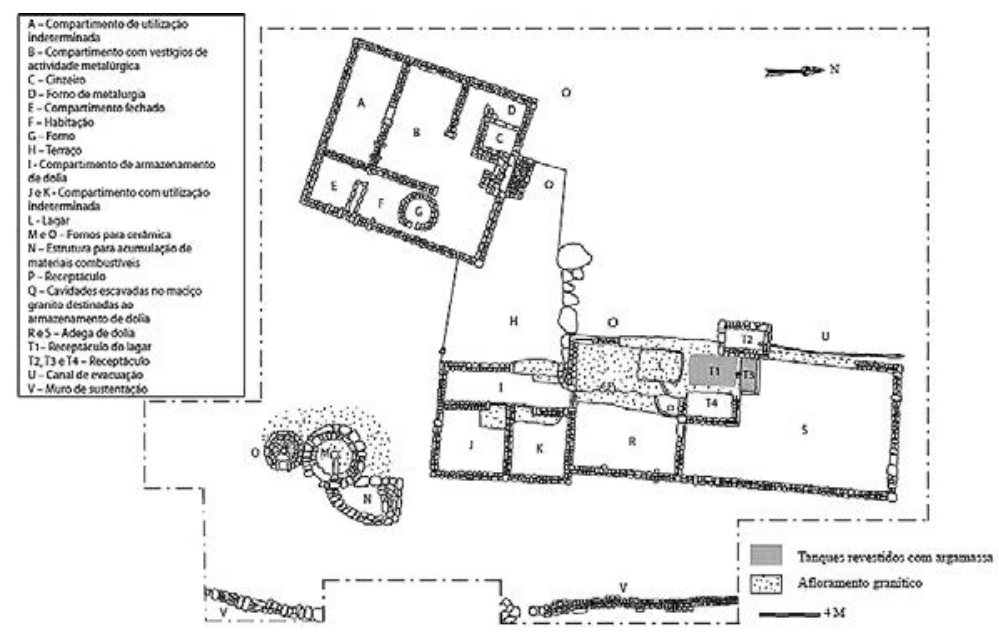

Fig. 3.

Planta do sítio de Rumansil I, Murça do Douro, Vila Nova de Foz Côa. Infografia de Tony Silvino.

colaborado, tem vindo a desenvolver prospecções e trabalhos de campo em centenas de sítios arqueológicos, sendo grande parte deste trabalho dedicado às explorações agrícolas de época romana.

Rumansil I, em Murça do Douro, é um dos exemplos mais paradigmáticos para compreender como é que se desenvolveu a prática agrícola, especialmente a vitivinicultura, no Vale do Douro no período clássico. O sítio compreende três conjuntos de estruturas principais: um edifício onde foram encontrados restos de uma estrutura de forja ${ }^{13}$, uma cella vinaria e duas estruturas de fornos circulares, paralelos, aos quais se encontra adossada uma estrutura de armazenamento de materiais combustíveis. Todas estas estruturas aparentam estar relacionadas com a prática da vitivinicultura: a forja para a produção de alfaia agrícola; a cella vinaria para a transformação do mosto em vinho e, finalmente, os fornos de cerâmica, utilizados tanto para a produção de cerâmica de consumo como dolia, grandes recipientes cerâmicos onde decorreria a última fase da fermentação do mosto.

A hipótese interpretativa que, nos últimos anos, temos colocado sobre o sítio de Rumansil I é que este seria uma estrutura «anexa» a uma estrutura de carácter agrícola de maiores dimensões, o sítio do Prazo. Localizando-se apenas a cerca de 2 $\mathrm{km}$ de distância, o Prazo é composto por uma série de estruturas, maiores dimensões, com uma grande cella vinaria, num edifício de cerca de $160 \mathrm{~m}^{2}$ e com estruturas de transformação e armazenamento de cereais, entre outras ${ }^{14}$.

\footnotetext{
${ }^{13}$ COIXÃO, 2017.

${ }^{14}$ COIXÃO, 2017.
} 
A cronologia de ocupação destes dois sítios coincide, embora no caso do Prazo a ocupação, no período clássico, seja compreendida entre, pelo menos, o século II e V da nossa Era, enquanto que no caso de Rumansil I as cronologias de ocupação são bem menos amplas, entre os séculos III e IV d. C. Esta diacronia aparenta comprovar o facto de Rumansil I se tratar de uma extensão do Prazo, funcionando como uma unidade de produção agrícola especializada, neste caso de vinho, onde este seria produzido, ficaria em estágio e, a dado momento, de onde seria escoado para os mercados. Esta teoria sobre a funcionalidade do sítio constituiria uma evolução morfológica do que pensamos ter sucedido com os lagares escavados na rocha, estruturas normalmente descobertas em zonas isoladas, mas que estariam no fundus de uma exploração agrícola e, produzindo o vinho na zona de produção, facilitaria o seu transporte ${ }^{15}$.

A descoberta de um fragmento de dolium produzido em Rumansil I com o grafito «LF» ${ }^{16}$ poderá também ajudar-nos a compreender a produção cerâmica especializada na região. A presença deste elemento aponta para uma venda destes grandes recipientes para outras propriedades no Vale do Douro, uma vez que no Alto da Fonte do Milho e em Zimbro II foram encontrados fragmentos de dolia com os mesmos grafitos, ou uma produção itenerante de dolia, realizada por artesãos que viajariam de exploração em exploração para produzirem este tipo de recipiente. Infelizmente, conhecemos ainda muito mal as produções cerâmicas de tipo comum nesta região para podermos retirar outras elacções, embora tenham sido realizados avanços meritórios neste campo nas últimas décadas ${ }^{17}$.

Zimbro II, em Mós do Douro, Freixo de Numão (Vila Nova de Foz Côa), outro estabelecimento agrícola de época romana intervencionado por António de Sá Coixão e a sua equipa, resultou em dados extraordinários. Interpretado enquanto uma pequena exploração rural, o sítio possui dois tanques que aparentam ter sido utilizados para preparados de peixe ${ }^{18}$. Estão também presentes vestígios de produção de cereais, sob a forma de estruturas de moagem e um possível horreum. No entanto, a produção cerealífera na área da actual aldeia de Freixo de Numão na época flaviana encontra-se bem atestada em várias zonas, desde as escavações na Casa Grande, onde foi descoberto um horreum, até a uma outra dezena de estabelecimentos de pequenas dimensões dispersos pela área em torno da aldeia actual ${ }^{19}$.

\footnotetext{
${ }^{15}$ PEREIRA, 2017; PEREIRA, 2018.

${ }^{16}$ PEREIRA, 2017.

${ }^{17}$ DIAS, 1997; SILVINO et al, 2003; COIXÃO et al, 2015; PEREIRA \& MORAIS, 2016.

${ }^{18}$ COIXÃO, 2017.

${ }^{19}$ COIXÃO, 2017.
} 


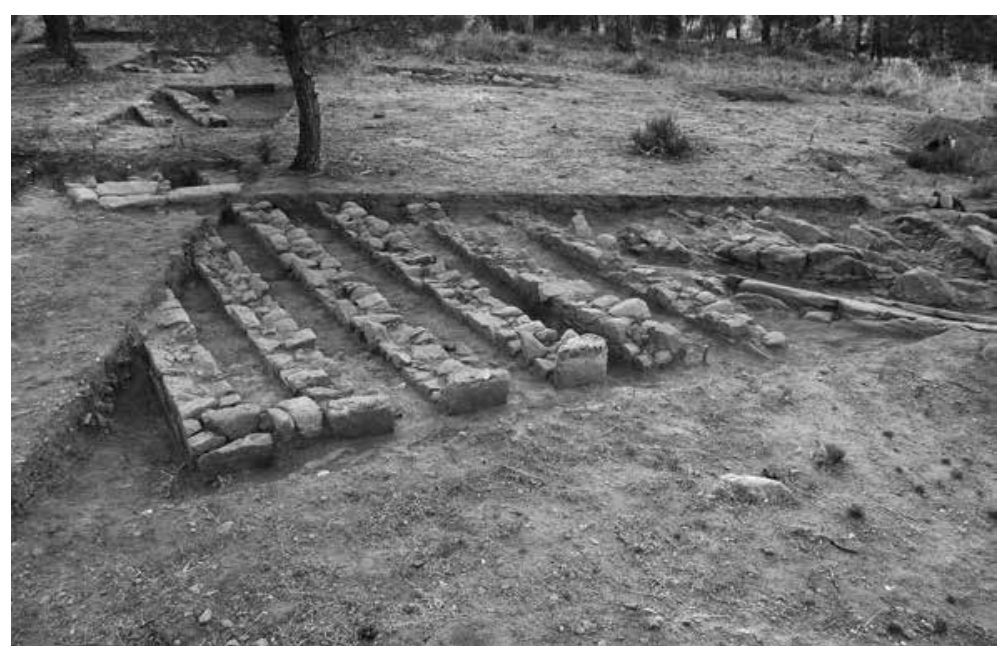

Fig. 4.

Horrea de Vale do Mouro (Coriscada, Mêda).

Cliché de Damien Tourgon.

O sítio de Vale do Mouro, em Gravato, Coriscada (Mêda) é também um sítio paradigmático para compreender como se estrutura a organização do campo na época romana no Vale do Douro português.

A intervenção iniciada em 2003 e que se encontra a decorrer identificou uma villa romana com uma ampla diacronia de ocupação e com uma evolução arquitectónica extremamente interessante. A datação do início da edificação da primeira estrutura de exploração agrícola data de finais do século I d. C., com a construção de uma villa linear, de formato rectangular ${ }^{20}$. Esta estrutura irá transformar-se, a partir do final do século II, numa villa clássica de peristilo, com produções bem atestadas de cereais, vinho e minério. Todavia, se estes tipos de produções são comuns no Vale do Douro no período em questão, em Vale do Mouro as dimensões e capacidades produzidas multiplicam-se exponencialmente.

Os dois horrea de Vale do Mouro têm uma capacidade mínima para albergar $400 \mathrm{~m}^{3}$ de grão e/ou farinha, supondo, claro, que apenas teriam um andar funcional. Foram também identificadas dezenas de estruturas de moagem, incluíndo mós de cereais de tipo Zugmatel. A descoberta do paleo-leito de um ribeiro próximo do estabelecimento, associado à descoberta de uma grande quantidade de mós na zona, leva-nos a crer que poderia ter existido uma transformação de cereal em moinhos de rodízio na Antiguidade, de resto, de uma forma muito similar ao que sucedia até à muito pouco tempo nas margens do Massueime, por exemplo, ao qual o ribeiro desaguaria.

\footnotetext{
${ }^{20}$ PEREIRA, 2017.
} 
Fig. 5.

Estruturas de lagares, Vale do Mouro

(Coriscada, Mêda). Cliché do autor.

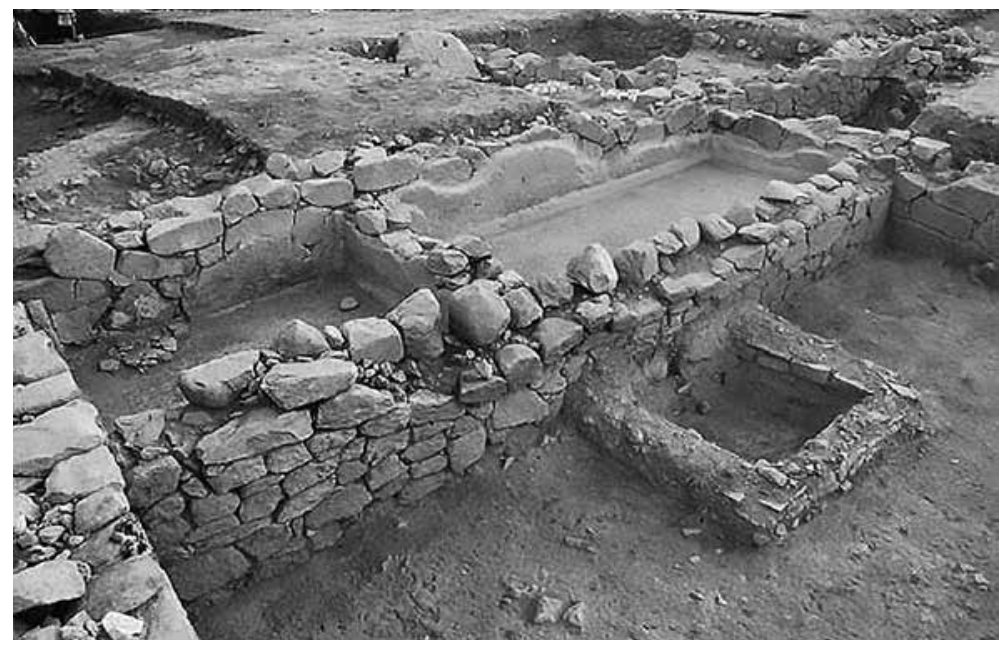

Fig. 6.

Depósito de minério,

Vale do Mouro

(Coriscada, Mêda).

Cliché de António Sá

Coixão.

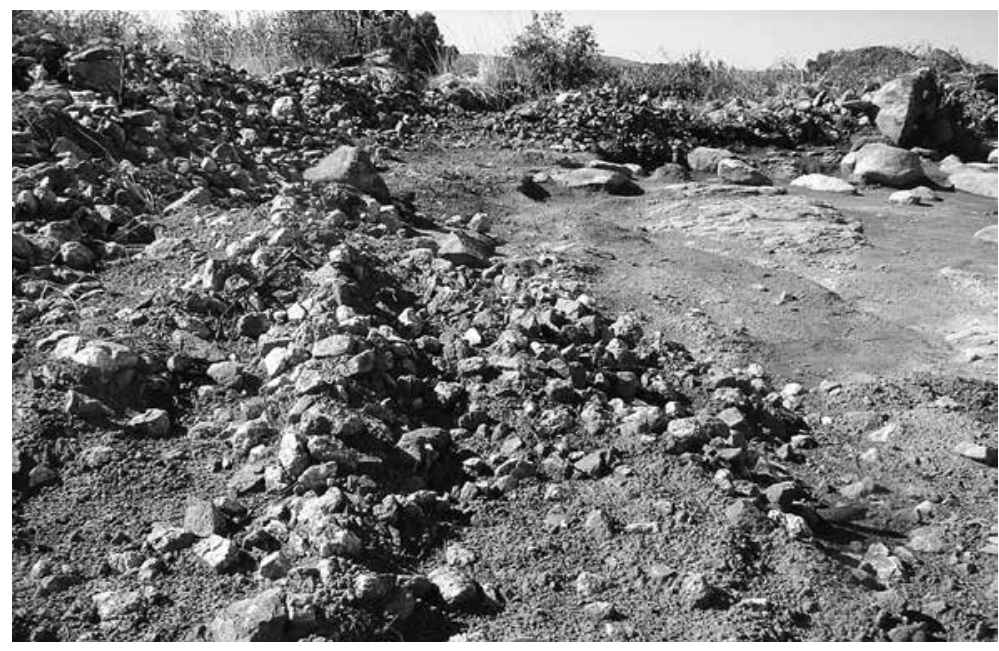

A cella vinaria de Vale do Mouro ocupa uma área de sensivelmente $170 \mathrm{~m}^{2}$. A sua bateria de tanques teria uma capacidade de produção mínima de 1.500 litros de vinho, utilizando uma grande prensa de tipo catoniano. Durante o processo de escavação desta área, foram identificados, registados e desmontados muros relativos a uma ocupação tardia, do século VI d. C. No extremo Sul da cella vinaria foram também identificadas duas ocupações, uma mais antiga e outra mais recente. Num momento anterior à ocupação, entre os séculos II e III da nossa Era, é utilizada uma prensa em pedra, uma lagareta, na zona Sul do edifício. O facto de nessa mesma zona existir uma conduta de água e de o receptáculo da lagareta ser um dolium revestido 
a cal, associado a paralelos conhecidos noutros pontos do Mediterrâneo ${ }^{21}$, leva-nos a crer estarmos perante um lagar de azeite, que terá sido abandonado anteriormente à utilização do espaço enquanto cella vinaria. Posteriormente, já numa fase de decadência e abandono das áreas nobres da villa, a lagareta será re-utilizada como mesa ou suporte, assentando em bases de colunas, também elas em posição de re-utilização.

A par das produções agrícolas, a exploração de minério encontra-se também patente no mundo rural da antiguidade no Vale do Douro. Em Vale do Mouro foram identificadas áreas de forja e fornos de fundição. Foi ainda identificada uma estrutura de preparação de minério e uma área de armazenamento de estanho.

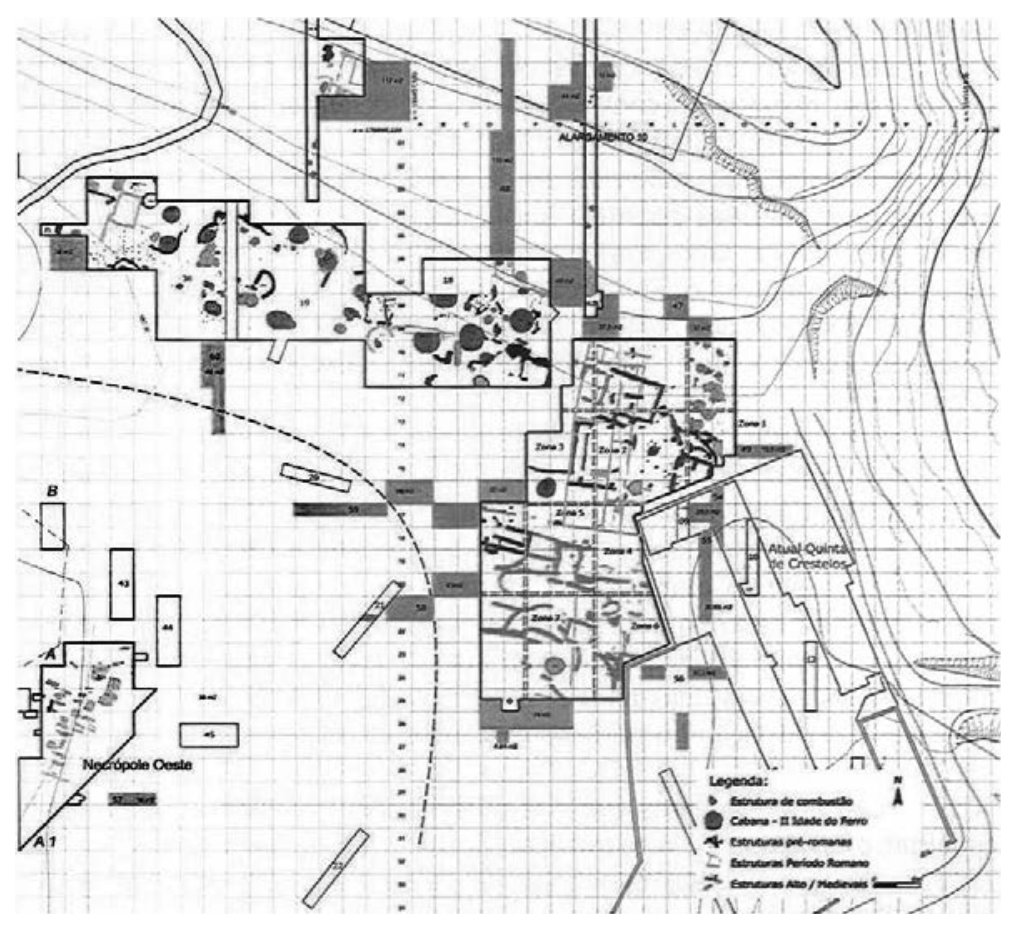

Fig. 7.

Planta das estruturas intervencionadas na Quinta de Crestelos (Santo Antão da Barca). Infografia do ACE Sabor.

Foi ainda possível detectar em Vale do Mouro uma série de divisões, na pars urbana do estabelecimento, dedicadas à tecelagem, tendo sido recolhido um espólio rico de bases de fusos e pesos de tear. Finalmente, foi identificada uma área de cavalariças, sendo muito provável a prática de pecuária na zona, sobretudo a partir das

\footnotetext{
${ }^{21}$ BRUN, 2003.
} 
Fig. 8. Horreum da Quinta de Crestelos (Santo Antão da Barca). Cliché de Susana Cosme.

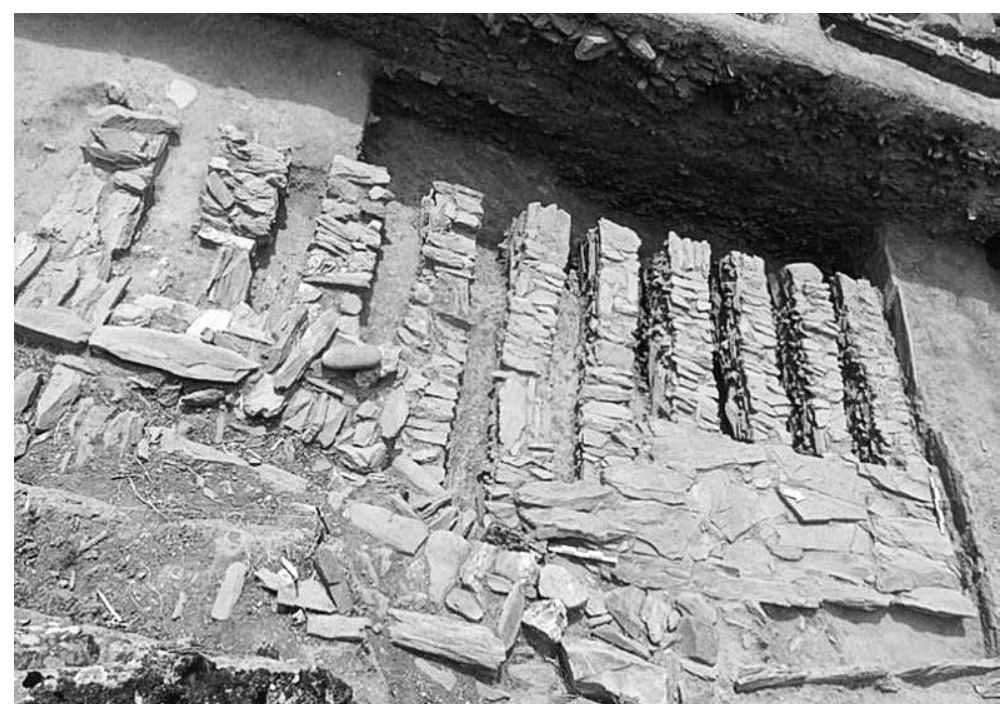

$\mathbb{N}$

Fig. 9.

Planta de Trás do Castelo<smiles>C1CCCCC1</smiles>

(Vale de Mir, Pegarinhos,

Alijó).

Infografia de Tony Silvino

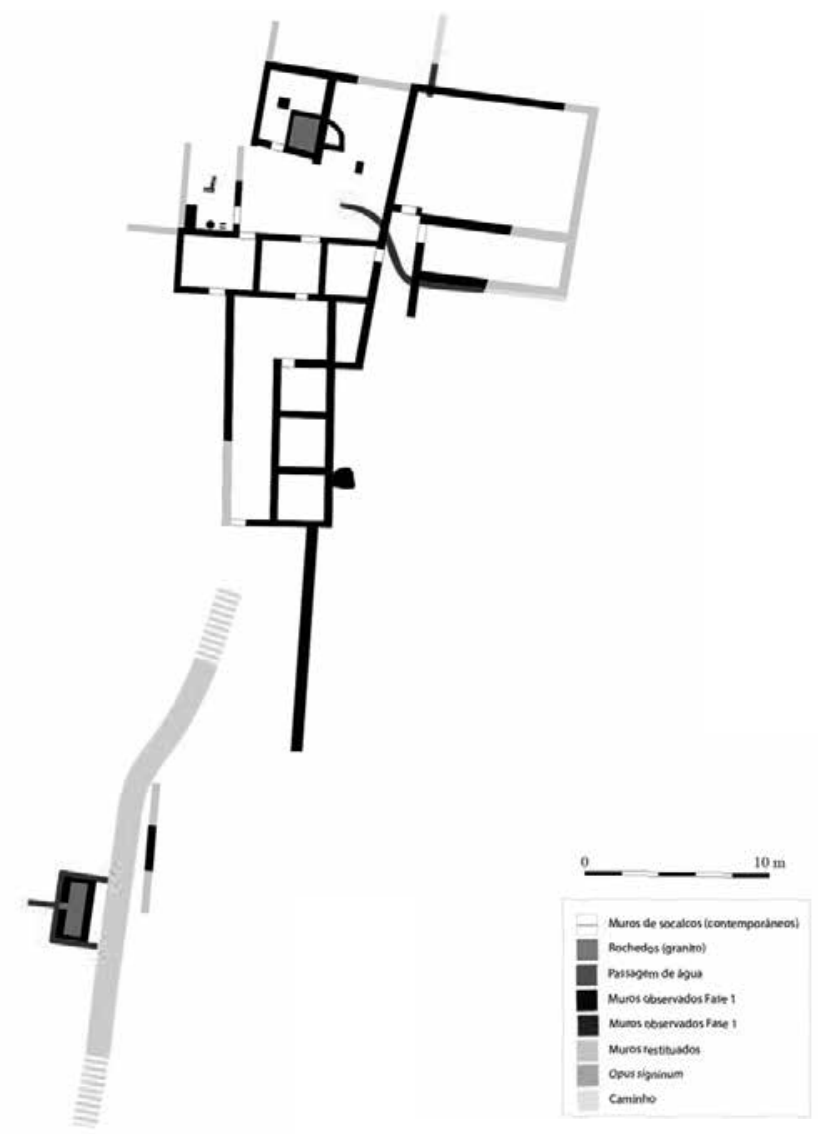


identificações de espécies através da zooarqueologia ${ }^{22}$. Infelizmente, não foi possível identificar áreas de habitat para estes animais.

Na última década foram desenvolvidos vários grandes projectos de contrução no território duriense. Um destes projectos, o Empreendimento Hidro-Elétrico do Baixo Sabor, resultou na descoberta, intervenção e estudo de dezenas de novos sítios de diversos horizontes cronológicos.

O trabalho empreendido no sítio da Quinta de Crestelos permitiu a identificação de um povoado da Idade do Ferro que, durante a Antiguidade Tardia, será re-estruturado em função de um cariz exclusivamente de produção e armazenamento agrícola. Os investigadores que realizaram as escavações neste sítio identificaram estruturas agrícolas da Idade do Ferro, nomeadamente um celeiro de planta circular e estruturas de moagem, que serão re-utilizadas e sofrerão ampliações no período de domínio romano: será construído um novo celeiro de planta rectangular e uma cella vinaria ${ }^{23}$.

Em 2012 foi iniciado um projecto de sondagens e prospecções em torno do Castro de Vale de Mir, Pegarinhos (Alijó). Com o intuito de compreender como é que se desenrrolou o processo de romanização, foram abertas sondagens na área nascente imediatamente abaixo da área do castro.

O projecto de investigação permitiu a escavação de uma pars agricola de uma villa extremamente interessante, uma vez que esta área, embora rica em povoados da Idade do Ferro identificados, não tem sofrido intervenções nas últimas décadas, desconhecendo-se em grande parte como decorreu a ocupação rural no período clássico no território do planalto de Alijó do Vale do Douro.
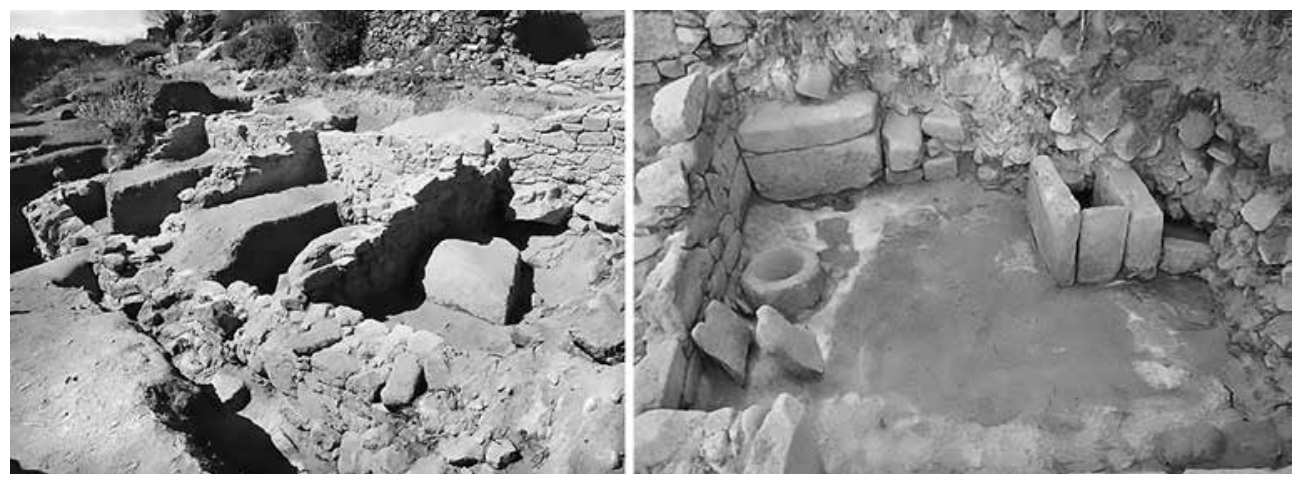

Fig. 10. Estábulos e tinturaria de Trás do Castelo (Vale de Mir, Pegarinhos, Alijó).

Clichés de Tony Silvino.

\footnotetext{
${ }^{22}$ ARGANT, 2013.

${ }^{23}$ COSME, 2013.
} 
Fig. 11.

Estrutura de lagar de São João das Arribas (Aldeia Nova, Miranda do Douro).

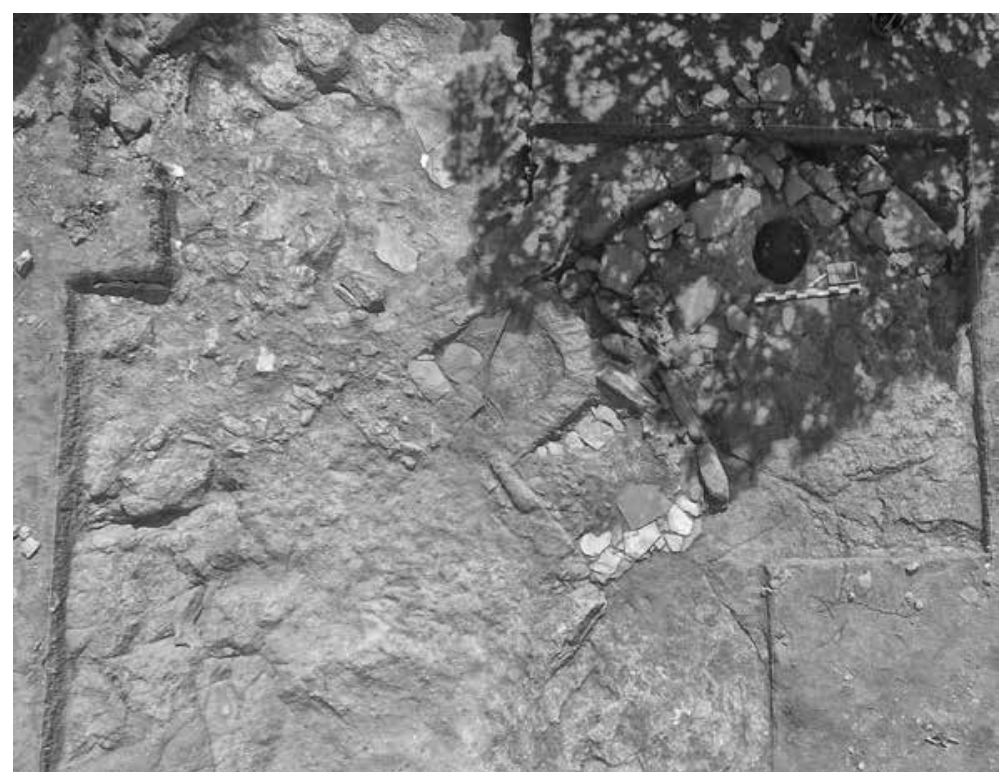

Na pars rustica de Vale de Mir foram identificadas estruturas de moagem e um horreum com uma datação relativa do século II d. C. Foi também possível descobrir uma cella vinaria e, aquando da escavação da area da prensa, foi descoberto um denário no interior da argamassa, em flor de cunho, com cunhagem em Roma a $84 \mathrm{~d}$. C. Este achado permitiu datar o momento de construção do lagar para um momento algures no final do século I d. C.

No entanto, o sítio de Trás do Castelo, em Vale de Mir, prima por dois elementos que aparentavam ser desconhecidos no mundo rural romano do Vale do Douro até ao início deste projecto: um atelier de tinturaria numa exploração rural, com tanques, estruturas de maceração de matérias primas e outros elementos; e estruturas dedicadas ao habitat de gado, verdadeiras estruturas de estábulos.

Em 2016 foi iniciado um novo projecto de investigação no Castro de São João das Arribas, Aldeia Nova (Miranda do Douro). Embora este sítio esteja classificado como monumento nacional desde 1910, eram muito poucos os dados conhecidos.

Durante a campanha de 2017, foram identificados vários espaços de cariz habitacional e, numa das sondagens realizadas, foi descoberta uma estrutura de lagar, com uma datação relativa do século III d. C. Sobre os níveis de demolição do lagar foram descobertas várias peças completas, de cronologia medieval, nas quais foi armazenado cereal (triculum aestivum), queimado. Embora ainda se encontre em fase de estudo e sendo apenas possível realizar datações relativas aos materiais cerâmicos, esta descoberta é extremamente interessante: num espaço de dois séculos dá-se uma 
mutabilidade total a nível de produção no sítio, alterando-se de uma função vinícola para, aparentemente, uma função de armazenamento de cereais.

Como pudemos observar, nas últimas décadas tem vindo a desenvolver-se vários projectos de investigação sobre a ocupação agrária romana no Vale do Douro. No entanto, se muitas questões têm recebido resposta, muitas mais têm surgido. Quais seriam os mercados de escoamento para tantos produtos vindos do Vale do Douro e quais seriam as rotas comerciais, para além do próprio rio que, sabemos hoje, permitiria navegação em grande parte da sua extensão? Como é que se processa esta interessante transição entre o mundo latino e o mundo medieval no campo? Como é que se processam as diacronias constructivas e arquitectónicas latinas com as realidades culturais endógenas do Vale do Douro?

Infelizmente, a demarcação pombalina de 1758 e posteriores alargamentos irão iniciar um processo de arroteamentos e transformação da paisagem do Vale do Douro que irá re-construir totalmente o território duriense. Desaparecerão muitos sítios e outros serão de tal forma transformados que farão com que a sua interpretação seja extremamente complexa, como sucede com o sítio da Quinta do Noval, intervencionado por Ricardo Severo, no início do século $\mathrm{XX}^{24}$.

O panorama agrícola do Vale do Douro português durante a Antiguidade é extremamente rico, cheio de mutações arquitectónicas e uma apropriação da paisagem e do território sui generis. Todavia, existe ainda muito trabalho por fazer. A utilização de novas tecnologias na detecção e teledetecção de sítios arqueológicos é muito complexa nas vertentes do Douro, onde, muitas vezes, os arqueosítios encontram-se em zonas de difícil acesso e, por isso mesmo, foram conservados, sendo necessário um grande trabalho de prospecção, ainda por realizar. Ao mesmo tempo, é necessária uma re-avaliação, ou mesmo uma primeira análise, em alguns casos, da documentação proveniente dos sítios intervencionados nas últimas décadas, que poderão conter, de resto, resposta a muitas das interrogações que nos colocamos hoje aquando da elaboração de sínteses históricas sobre a presença romana no Vale do Douro.

\section{BIBLIOGRAFIA}

ALMEIDA, Carlos Alberto Brochado de (2006) - História do Douro e do Vinho do Porto - História Antiga da Região Duriense. Porto: Afrontamento, vol. I.

ARGANT, Thierry (2013) - Relatório preliminar de zooarqueologia. Relatório de intervenção da campanha de 2012 em Vale do Mouro, apresentado à DGPC. Policopiado.

BRUN, Jean-Pierre (2003) - Archéologie du vin et de la huille dans le Mediterranée Antique. Paris: Editions Errance.

COIXÃO, António Nascimento de Sá (1995) - Carta Arqueológica do Concelho de Vila Nova de Foz Côa. Vila Nova de Foz Côa: Câmara Municipal.

${ }^{24}$ SEVERO, 1903; PEREIRA, 2008. 
(2002) - Lagares e lagaretas nas Áreas de Freixo de Numão e Murça do Douro (Concelho de Vila Nova de Foz Côa). «Coavisão», vol. 4. Vila Nova de Foz Côa: Câmara Municipal, p. 57-71.

(2009) - Carta Arqueológica do Concelho de Mêda. Mêda: Câmara Municipal.

(2017) - A Romanização do Baixo Côa. Porto: Faculdade de Letras da Universidade do Porto. Tese de doutoramento.

COIXÃO, António do Nascimento Sá; MAZZA, Guillaume; SILVINO, Tony (2003) - Os fornos de cerâmica de Rumansil I (Murça do Douro, Vila Nova de Foz Côa), «Coavisão», 5. Vila Nova de Foz Côa: Câmara Municipal.

COIXÃO, António Nascimento de Sá; SILVINO, Tony (2009) - Coriscada, une grande villa romaine du Portugal. «Archéologia», vol. 464. Lyon.

COIXÃO, António Nascimento de Sá; PEREIRA, Pedro; SILVINO, Tony (2015) - La producción vinícola romana en el Nordeste portugués: los ejemplos de Rumansil I (Murça do Douro) y Vale do Mouro (Coriscada). In CONTRERAS, Margarita; ELIAS, Luis Vicente, coord.- Lagares rupestres. Aportaciones para su investigación. Vitoria: Adra, p. 24-27.

CORTEZ, Fernando de Russel (1947a) - Breve relato da primeira viagem de prospecção arqueológica na Região Demarcada do Douro. Dactilografado.

(1947b) - Relatório da primeira campanha de escavações de Canelas do Douro levada a cabo pelo Instituto do Vinho do Porto. Dactilografado.

(1947c) - Diário das escavações do Alto da Fonte do Milho. Manuscrito.

(1948a) - Relato da segunda campanha da Fonte do Milho, Canelas. Dactilografado.

(1948b) - Arqueologia da região produtora do Vinho do Porto. «Anais do Instituto do Vinho do Porto", nº 9. Porto: IVP.

(1951) - As escavações arqueológicas do «Castellum» da Fonte do Milho. Contributo para a demogenia duriense. "Anais do Instituto do Vinho do Porto», $n^{\circ} 12$ (1). Porto: IVP.

COSME, Susana Rodrigues (2002) - Entre o Côa e o Águeda: Povoamento Romano e Alto-Medieval. Porto: Faculdade de Letras da Universidade do Porto. Dissertação de Mestrado.

(2013) - O contributo das pequenas 'villae' rústicas na economia e povoamento dos séculos IV-VII no Douro. In Actas das 1as Conferências do Museu de Lamego. Lamego: CITCEM/Museu de Lamego, p. 141-149.

DIAS, Lino Tavares (1997) - Tongogriga. Lisboa: IPPAR/Ministério da Cultura.

FERNANDES, Armando de Almeida (1968) - Paróquias Suevas e Dioceses Visigóticas. Viana do Castelo. MOMMSEN, Theodor (2004) - The Provinces of the Roman Empire. Nova Iorque: Barnes \& Noble.

MORAIS, Rui (1997-1998) - Sobre a hegemonia do vinho e a escassez do azeite no Noroeste Peninsular nos inícios da romanização. «Arqueologia». vol. 14-15. Porto, p. 175-182.

PEREIRA, Pedro (2007) - A produção de vinho no Vale do Douro durante a Romanização. Seminário de Projecto do curso de Arqueologia, FLUP. Porto. Policopiado.

(2008) - Economie et Production du vin dans la vallée du Douro (Portugal) dans l'Antiquité tardive. Mémoire de Master II Recherche, Maison de l'Orient et de la Méditerranée. Lyon: Policopiado. (2012) - Materiais esquecidos - o espólio cerâmico de armazenamento (dolia) do Alto da Fonte do Milho, Peso da Régua. «Almadan», tomo 1, 17. Almada.

(2013a) - Uma história de dolia - uma primeira análise aos recipientes cerâmicos de armazenagem de Vale do Mouro (Coriscada, Meda). "CEM Cultura, Espaço e Memória: Revista do CITCEM», n. ${ }^{\circ}$ 2, p. $75-82$.

(2013b) - De vino ac vineas - viticultura romana no Vale do Douro. In Actas das 1as Conferências do Museu de Lamego. Lamego: CITCEM/Museu de Lamego, p. 141-149.

(2015) - A importância da Arqueologia para a história da vinha e do vinho na região do Douro. In Actas das 3 as Conferências do Museu de Lamego. Lamego: CITCEM/Museu de Lamego, p. 141-149. 
(2016) - Estrangeiros no Vale do Douro - os romanos na transduriana provincia. In Actas das 4as Conferências do Museu de Lamego. Lamego: CITCEM/Museu de Lamego, p. 141-149.

(2017) - O Vinho na Lusitânia. Porto: Ed. Afrontamento/ CITCEM.

(2018) - O vinho e a vinha no contexto da romanização do Vale do Douro português. In Actas do $1^{\circ}$ Simpósio Internacional sobre Lagares Rupestres. Valpaços: Câmara Municipal de Valpaços (no prelo).

PEREIRA, Pedro; MORAIS, Rui (2015) - Estudo Crono-tipológico de dolia romanos em Portugal. «Ex Officina Hispona-Cuadernos de la SECAH», n. ${ }^{\circ}$ 2, t. 1, p. 33-34. Madrid: La Ergástula.

REBANDA, Nelson Campos (2008) - Inventário de patrimóno arqueológico e de alguns valores arquitectónicos do concelho de Torre de Moncorvo. Torre de Moncorvo: PARM.

SEVERO, Ricardo (1903) - Notícia da estação romana da Quinta da Ribeira em Tralhariz. «Portugália», 1 , Porto.

SILVINO, Tony; COIXÃO, António de Sá; MAZA, Guillaume (2003) - Os fornos de cerâmica do Rumansil I - Murça-do-Douro (Vila Nova de Foz Côa). Estudo preliminar. «Coavisão», n. ${ }^{\circ}$ 5, p. 85-97. Vila Nova de Foz Coa: [Câmara Municipal].

SILVINO, Tony; PEREIRA, Pedro (2017) - O projecto de investigação sobre a ocupação humana em torno da aldeia de Pegarinhos (Alijó) - em busca das origens da Romanização do Douro. In Actas do $2^{\circ}$ Congresso da Associação dos Arqueológos Portugueses, p. 1085-1095.

TEIXEIRA, Carlos (1939) - Estação romana de Canelas (Poiares da Régua). «Trabalhos da Sociedade Portuguesa de Antropologia e Etnologia», vol. IX, Porto. Separata. 



\section{LAS VILLAS ROMANAS EN CASTILLA \\ Y LEÓN (ESPAÑA): PROTECCIÓN, \\ INVESTIGACIÓN Y PUESTA EN VALOR}

MARGARITA SÁNCHEZ SIMÓN*

Es indudable que entre las estrategias de potenciación del turismo de interior en Castilla y León, los productos basados en bienes de naturaleza arqueológica tienen un papel cada vez más creciente. Si tomamos por ejemplo la última edición de la Feria INTUR (Feria Internacional del Turismo de Interior) celebrada en noviembre de 2018, entidades de ámbito público — entre ellas ciertas diputaciones provincialesapostaron con fuerza por hacer de esos recursos elementos turísticos destacables. Pero no solamente están presentes estos vestigios de nuestro pasado en eventos concretos, además lo están en diversos materiales de difusión y propaganda tanto de índole turística como en aquellos otros que dan a conocer el patrimonio cultural (guías arqueológicas, webs, ...). Ciudades, aldeas o castros, calzadas, acueductos, arcos monumentales, murallas, campamentos y villas, especialmente estas últimas, aparecen entre los sitios/recursos ofertados para su visita ${ }^{1}$. Solo hay que ojear las publicaciones impresas o digitales para obtener información sobre qué visitar, dónde ir, cómo llegar, ... y darse cuenta que los yacimientos arqueológicos están muy presentes. Esta realidad solo ha sido posible gracias a años de políticas de inversión principalmente promovidas por parte de las administraciones públicas en el marco de planes estratégicos muy concretos.

\footnotetext{
* Museo de las Villas Romanas de Almenara-Puras (Almenara de Adaja-Puras, Valladolid) Universidad de Burgos, Departamento de Historia, Geografía y Comunicación, Área de Historia Antigua. margaritasanchezsimon@gmail.com. ${ }^{1}$ VAL RECIO \& ESCRIBANO VELASCO, 2004.
} 
Mi contribución a este encuentro se centrará en un elemento muy determinado del patrimonio arqueológico, en la tipología de yacimiento que son las villas romanas en la cuál se ha realizado un gran esfuerzo en Castilla y León en las últimas décadas. Las actuaciones desarrolladas para su identificación, protección, investigación, puesta en valor y difusión explican por qué actualmente existe una oferta nada desdeñable en este ámbito y varias iniciativas en curso.

¿Qué son las villas? ¿Por qué las villas? Dentro del modelo o patrón romano de asentamiento en el territorio las ciudades eran fundamentales; eran los centros de administración y gestión de un territorium en el que se distribuían otros núcleos de menor entidad - entre ellos granjas, aldeas y villas - según el modelo de organización puesto en marcha por Roma tras la conquista. Surgen las villas - por tanto- como un espacio de explotación agropecuaria; pero al tiempo son un lugar privilegiado en el cual las élites podían vivir dedicadas a disfrutar de ciertas actividades propias del retiro campestre ${ }^{2}$. Esa dualidad es la realidad de las villae. No obstante la percepción que fuera del ámbito académico está más extendidas es que «villa» es sinónimo casi exclusivo de un suntuoso edificio residencial caracterizado por tener magníficos pavimentos musivos. No es de extrañar que esa sea la imagen más frecuente puesto que los grandes edificios residenciales de las quintas bajoimperiales, especialmente las meseteñas, así lo avalan. Y ciertamente esa percepción es una de las razones que ya en el siglo XIX se aducía para protegerlas y conservarlas ${ }^{3}$. Pero no es la única que ha favorecido las actuaciones de puesta en valor; sus dimensiones hacen más factible su completa excavación y la construcción de estructuras de cubrimiento que favorezcen la vista, a la par que la imprescindible conservación de unos vestigios exhumados y desprotegidos de las capas de tierras que las salvaguardaron durante siglos.

Pero las villas son mucho más. No es por supuesto objeto de mi contribución al encuentro exponer los aspectos que centran la investigación sobre el hábitat rural de tipo disperso; para ello hay otros foros. Lo que pretendo en las siguientes páginas es explicar el porqué y cómo este tipo yacimiento se han convertido en un recurso patrimonial altamente valorado en Castilla y León, cómo se han sucedido -en líneas generales- los procesos de identificación, protección, puesta en valor y difusión turística de los ejemplos más destacados, actuaciones estas últimas en las que han aunado esfuerzos diferentes administraciones, y por qué generan el interés en el público que hace que se hayan convertido en todo un producto turístico, como es el caso de varios ejemplos castellanoleoneses que integran la iniciativa Red de Villas Romanas de Hispania ${ }^{4}$.

\footnotetext{
${ }^{2}$ GARCÍA MERINO \& SÁNCHEZ SIMÓN, 2015: 53-55.

${ }^{3}$ Los ejemplos de San Julián de la Valmuza y de Navatejera son muy significativos (REGUERAS GRANDE, 2013: 159-160). ${ }^{4} \mathrm{http}$ ///www.villasromanas.es/ Otra web que recoge diversos recursos tipo villa que se pueden visitar en Europa es: http://www.villasromaines.fr/
} 


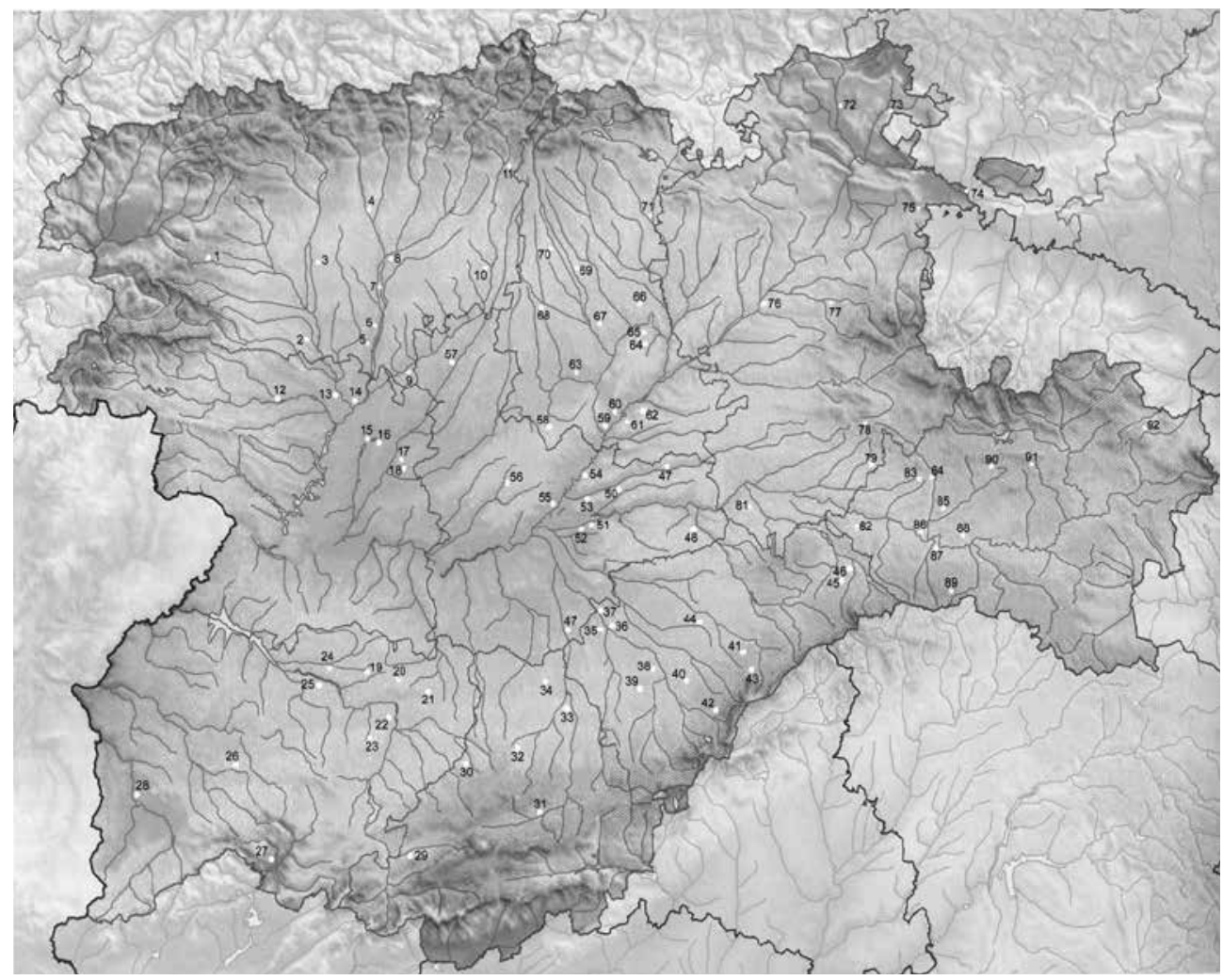

Fig. 1. Distribución de las principales villas romanas en Castilla y León, según F. Regueras.

Fuente: REGUERAS, 2013: 28.

\section{IDENTIFICACIÓN Y CARACTERIZACIÓN DE LAS VILLAS ROMANAS EN CASTILLA Y LEÓN}

Castilla y León es la Comunidad Autónoma más extensa de España. El número de yacimientos adscritos a la tipología de asentamiento rural/villa romana que figura en la base de datos del sistema de gestión del patrimonio cultural de Castilla y León (PACU) se acerca a los $1.300^{5}$. Evidentemente, hablar de un "asentamiento rural» no significa que todos los incluidos en esa categoría sean las villas de naturaleza suntuosa que generalmente tenemos en la cabeza cuando se menciona el término. La nómina de enclaves rurales es amplia y las palabras con las que los propios romanos los denominaron incluyen asentamientos como villula, vicus,.... y también villa. Por eso más allá de esa asociación, los elementos que en Castilla y León se adscriben a esa categoría son muy diversos: granjas u otros asentamientos con construcciones 
relativas a su naturaleza agropecuaria de tamaño pequeño o mediano, enclaves asociados al tránsito viario, ... y también los grandes centros de agropecuarios que disponen de zonas residenciales apropiadas para la vida de unas élites determinadas y que dan lugar a edificaciones que cuentan con un impresionante despliegue de lujo y comodidades. Villas entendidas en este último modo se conocen muchas menos, unas 92 si atendemos a la publicación de F. Regueras del año $2013^{6}$ (Fig. 1); su reparto por el territorio es desigual, hecho solo achacable a las diferentes circunstancias que han presidido su identificación e investigación. Y aunque es seguro que no todos los especialistas estarán de acuerdo con la adscripción de la totalidad de los yacimientos que se recogen en el mapa y pueda variar la cifra, esta es sin duda importante.

Así que, en términos de los instrumentos de gestión del patrimonio cultural, «villa romana» es una tipología de yacimiento arqueológico unida a la de «asentamiento rural». Para determinar cuándo se trata de una villa hay que emplear una serie de criterios de discriminación que permitan reconocer cuáles son aquellos hábitats que poseen una residencia suntuosa de tipo vilicario o áulico y que son, principalmente, la tipología del edificio y la presencia de mosaicos, de pinturas murales y restos escultóricos.

Estas villas cuentan con la protección que les brinda el ser elementos del patrimonio cultural de Castilla y León; como tales figuran en los diferentes instrumentos de ordenación y protección. Pero además, 21 han sido incoadas o declaradas BIC ${ }^{7}$; las razones que han motivado tal consideración están en relación con la suntuosidad de los restos así como con otros factores circunstanciales ${ }^{8}$ que aconsejaban esta medida como mejor modo de conservarlas o de favorecer las inversiones.

\section{ASPECTOS SOBRE LA INTERVENCIÓN E INVESTIGACIÓN EN LAS VILLAS CASTELLANOLEONESAS}

Para comprender por qué las villas romanas tienen la consideración de elemento singular en Castilla y León, ha de tenerse en cuenta cómo se ha desarrollado el proceso de identificación e intervención ${ }^{9}$, cuáles han sido los mecanismos que llevaron a considerar a esta tipología como un conjunto con personalidad propia, objeto de gestión por medio de planes específicos y de importantes intervenciones de puesta en valor.

\footnotetext{
${ }^{6}$ REGUERAS GRANDE, 2013: 29 y Lám. 7.

${ }^{7}$ El catálogo de bienes protegidos se puede consultar en el siguiente enlace: http://servicios.jcyl.es/pweb/portada.do. ${ }^{8}$ En este sentido señalamos la importancia que la puesta en marcha del «Plan de villae romanas de Castilla y León» en los 90 tuvo en los procesos de incoación/declaración de estos bienes.

${ }^{9}$ F. Regueras (REGUERAS GRANDE, 2013: 159-160) ha sistematizado las cuestiones relativas al hallazgo, excavación, intervención e investigación de las villas castellanoleonesas, estudio al que remitimos para conocer los pormenores y particularidades de cada etapa y yacimiento.
} 
Las primeras noticias que se tienen registradas sobre la aparición de restos suntuosos asociados a las quintas del valle del Duero datan de finales del siglo XVIII e inicios del XIX cuando, en el marco de la política sobre descubrimientos arqueológicos impulsada por los Borbones se excavan Pancorbo (León), Las Pizarras (Coca, Segovia), San Julián de la Valmuza (Salamanca), ... La aparición en este último sitio de un mosaico con la representación de Pegaso y las ninfas llevaron a impulsar su conservación, cercándolo y encomiando al párroco su cuidado. En pleno siglo XIX la identificación de villas (y en general de los yacimientos arqueológicos) estará condicionada por la creación de nuevas infraestructuras: el impacto de las redes de ferrocarril y de carreteras es muy destacable. Pero además hay que tener bien presente que con el surgimiento de las Comisiones Provinciales de Monumentos y su red de informadores se dio visibilidad a ciertos yacimientos — La Milla del Río (León), Camarzana de Tera (Zamora), Almenara de Adaja-Puras (Valladolid), Aguilafuente (Segovia), Quintana del Marco (León), en los que se realizan las primeras campañas de excavación. Entre todos destaca Navatejera (León) - , ejemplo de villa excavada, cubierta y protegida por decisión pionera de la Comisión de Monumentos de León a finales de los años 80 .

El siglo XX es una etapa compleja, con diferentes momentos o impulsos. Un paso importante en la catalogación de las villas como riqueza histórica lo supuso su inclusión - junto con el resto de los yacimientos arqueológicos - en los Catálogos Monumentales. Al amparo de la legislación correspondiente se inician intervenciones arqueológicas tanto a cargo de miembros de instituciones académicas, como también por particulares. El Soldán (León), Piedrahita (Ávila) y especialmente Cuevas de Soria (Soria) de la que se exhuma la práctica totalidad de la pars urbana, son ejemplos intervenidos en el primer tercio del siglo XX. En 1931, esta última, Navatejera y San Julián de la Valmuza serán declaradas Monumento Histórico Artístico. Tras la Guerra Civil Española, en las décadas centrales de la centuria se promovieron nuevas investigaciones bajo la supervisión de la Comisaría General de Excavaciones: Los Villares (Soria), Los Quintanares (Soria), Almenara de Adaja-Puras (Valladolid), Prado (Valladolid), Aguilafuente (Segovia), .... Coinciden estos momentos con la aparición de nuevos yacimientos como resultado de la mecanización de las tareas agrícolas y de las políticas de concentración parcelaria.

A partir de los últimos tres decenios del siglo XX y en el XXI las intervenciones en este tipo de yacimientos han conocido una completa renovación. Este periodo está presidido por la profesionalización de la arqueología, por la aplicación de nuevos postulados, por la mejora de las técnicas de excavación, por el avance en la investigación sobre la complejidad del fenómeno de las villas romanas y además por la consideración de estas como bienes susceptibles de ser musealizados in situ, faceta en la que se considera no solo su potencialidad como recurso económico, también su 
valor social entendido como el retorno a la ciudadanía de las inversiones realizadas. Las intervenciones arqueológicas y los estudios en este periodo han estado al amparo de la Ley de Patrimonio Histórico de 1985, de la asunción de competencias en esta materia por parte de Castilla y León, y por el desarrollo normativo autonómico ${ }^{10}$. En estas décadas se ha producido no solo un incremento del número de villas y una mejora en su conocimiento, además su consideración - lo mencionábamos en el párrafo anterior-como recurso patrimonial de indudable valor cultural, circunstancia que ha posibilitado que la «villa romana», en el marco estratégico de actuación de las administraciones, haya sido objeto de planes específicos.

A lo largo de estos años se ha potenciado la catalogación sistemática de los bienes integrantes del Patrimonio Arqueológico. En los 80 se impulsó el reconocimiento, identificación e inventario de yacimientos como instrumento para una gestión más eficaz. Desde entonces la versión inicial del Inventario de Yacimientos Arqueológicos de Castilla y León (que actualizaban los datos de las diferentes Cartas Arqueológicas) se ha visto mejorada sucesivamente con el desarrollo de nuevas prospección intensivas, aplicación de reconocimientos aéreos ${ }^{11}$, revisión de datos, implementación de los existentes, creación de SIG, etc, labores desarrolladas por diferentes equipos en el marco de distintas estrategias algunas impulsadas por la administración ${ }^{12}$, otras por equipos de investigación,... Todos esos datos están volcados en la base de datos del Sistema de Gestión del Patrimonio Cultural de Castilla y León (PACU). La nómina de villas romanas conocidas actualmente deriva de esta importante labor.

Las intervenciones arqueológicas en este periodo son cuantiosas e importantes y responden a diversas circunstancias. En primer lugar destacaremos la labor desarrollada por Javier Cortes y la Diputación de Palencia en la villa de La Olmeda (Saldaña, Palencia) todo un referente en este campo. Desde su descubrimiento en 1968 se ha acometido la excavación integral de toda la pars urbana, de varias necrópolis y de un sector de la zona rústica ${ }^{13}$. Directamente relacionado con las actuaciones en La Olmeda hay que considerar el proyecto que en 1969 pusieron en marcha la Universidad y la Diputación de Valladolid para la exhumación completa de la Villa romana de Almenara de Adaja-Puras, iniciativa que tras años de inactividad se retomó en 1996 dando lugar a la creación del Museo de las Villas Romanas de AlmenaraPuras en 2003. Otras empresas de las décadas de los 70 y 80 se realizaron en los yacimientos burgaleses de Los Casarejos (San Martín de Losa), Santa Cruz (Baños

\footnotetext{
${ }^{10}$ Ley 12/2002, de 11 de julio, de Patrimonio Cultural de Castilla y León y Decreto 37/2007, de 19 de abril, por el que se aprueba el Reglamento para la protección del Patrimonio Cultural de Castilla y León.

${ }^{11}$ Los trabajos de J. del Olmo entre 1989 y 2009 han sido esenciales para el reconocimiento de nuevas villas y la forma de sus edificios (OLMO MARTÍN, 2017).

12 Plan de Villas Romanas de Castilla y León (PVRCyL), Plan PAHIS del Patrimonio Cultural de Castilla y León 20142012 (PLAN PAHIS 2004-2012), Plan PAHIS del Patrimonio Cultural de Castilla y León 2020 (PLAN PAHIS 2020). ${ }^{13}$ ABÁSOLO \& MARTÍNEZ, 2012.
} 
de Valdearados), El Millar (Cardeñajimeno) y Ciella (Valdeande); los palentinos de villa Possidica (Dueñas) y La Tejada (Quintanilla de la Cueza); el salmantino de San Julián de la Valmuza (Doñinos); el segoviano de Santa Lucía (Aguilafuente); los sorianos de La Dehesa (Cuevas de Soria), San Pedro (Valdanzo), Los Quintanares (Rioseco de Soria) y Los Villares (Santervás del Burgo); el vallisoletano de Villa de Prado (Valladolid); y el zamorano de Requejo (Santa Cristina de la Polvorosa). En 1980, 5 nuevas villas se ven reconocidas como BIC: Almenara de Adaja-Puras, Prado, Ucero, Los Quintanres y Huerta del Río.

Iniciada la década de los 90, la Junta de Castilla y León pone en marcha el «Plan de villae romanas de Castilla y León» (PVRCyL $)^{14}$ como respuesta a la necesidad de definir acciones concretas y de planificar actuaciones sistemáticas sobre este conjunto de bienes con entidad propia que - lo hemos visto líneas arriba- estaban siendo reconocidos como bienes patrimoniales muy destacados (8 con categoría de BIC) y además objeto de diversas intervenciones arqueológicas. Para conseguir sus objetivos se dispusieron una serie de medidas de protección en el ámbito jurídico-administrativo (entre ellas los expedientes de incoacción/declaración de BIC que reconocían como tales a 11 más y los acuerdos con los propietarios o con entidades locales) y otras de evaluación al objeto de determinar en qué enclaves - teniendo presentes diversas circunstancias- se iba a intervenir y en qué grado. Se establecieron 4 niveles con el tipo de actuaciones a desarrollar: 1) restos que fueron tapados tras acometer estudios de documentación y análisis; 2) otros cuyas estructuras se señalizaron; 3) tres yacimientos en los que se contemplaron intervenciones de implementación de las infraestructuras ya existentes o de construcción de otras de modesta entidad; 4) y por último, otros tres - Almenara de Adaja-Puras, Cuevas de Soria y La Olmeda-, a los que la administración autonómica dio apoyo puesto que ya existía una decidida voluntad e implicación económica previa por parte de las entidades propietarias de los terrenos (en especial en el caso de las Diputaciones de Palencia y Valladolid) que, con dispar intensidad aseguraban la financiación de unos proyectos de gestión, conservación, cubrimiento y dotación de infraestructuras museísticas. Las actuaciones se han desarrollado con desigual ritmo y resultados. En 2003 se abre el Museo de las Villas Romanas de Almenara-Puras (MVR) (Fig. 2); en 2009 se inauguran las nuevas instalaciones de la Olmeda (Villa romana La Olmeda, VRO) (Fig. 3) que sustituyeron a la pionera estructura de los 80; y en 2012 comienza a funcionar el Museo de la Magna Mater (Cuevas de Soria) a pesar de las graves carencias y errores que atañen a la conservación, interpretación y presentación de los restos que aún hoy en día persisten.

\footnotetext{
${ }^{14}$ FERNÁNDEZ et al., 2010.
} 


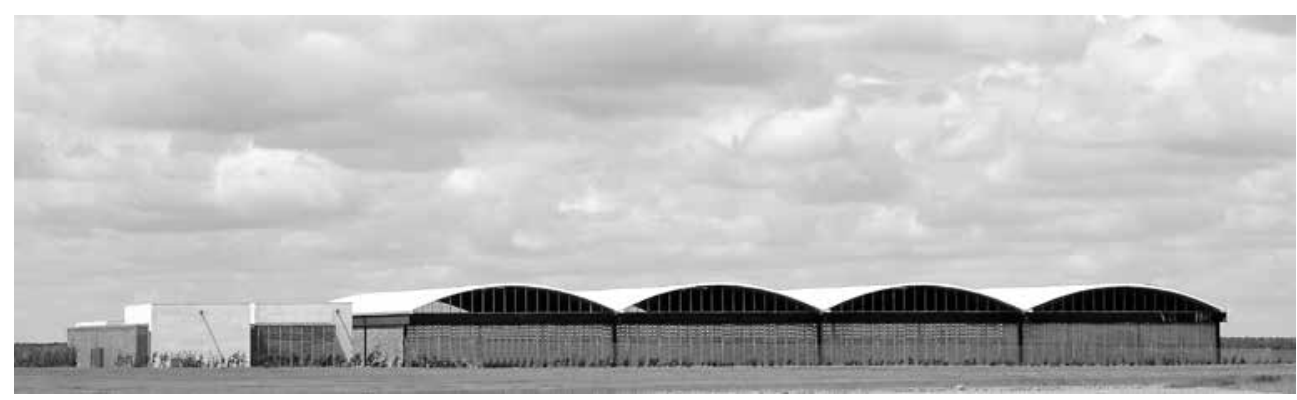

Fig. 2. El Museo de las Villas Romanas de Almenara-Puras (Valladolid). Fuente: MVR, Diputación de Valladolid.

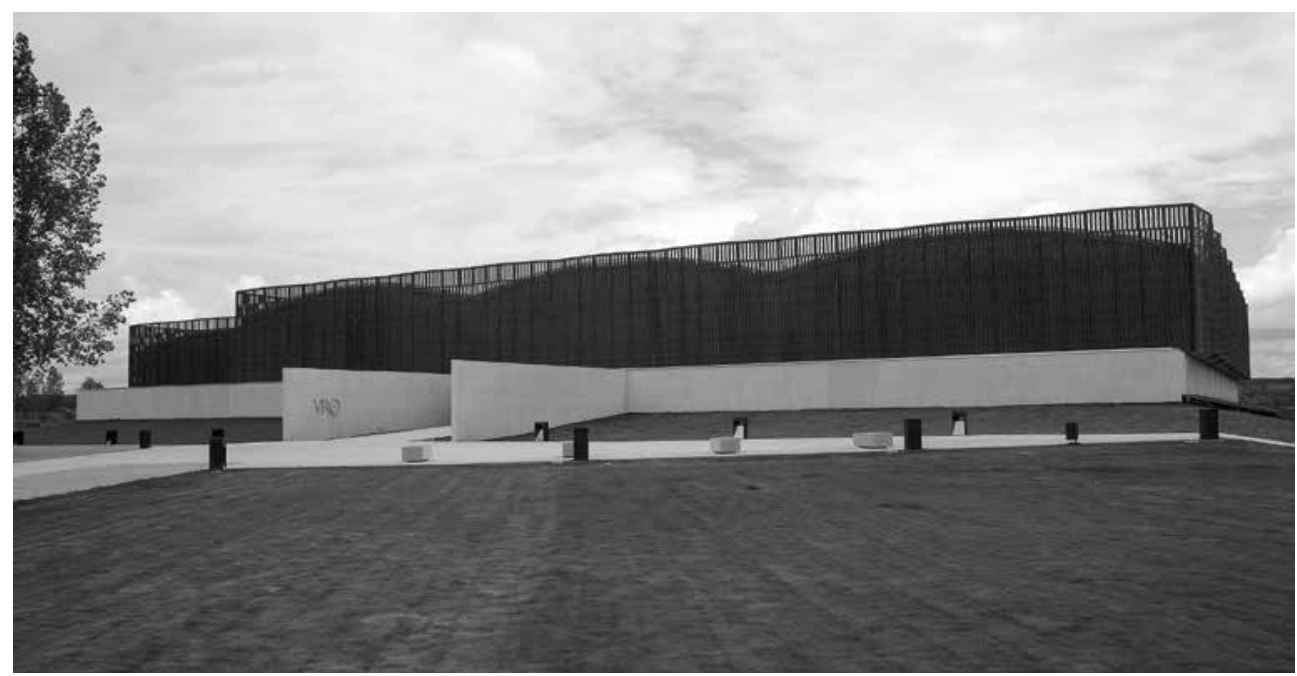

Fig. 3. Villa Romana La Olmeda (Palencia). Fuente: http://www.villaromanalaolmeda.com/portada?idSeccion=mi_0.

Superado el ámbito de actuación de ese plan, la Junta de Castilla y León promovió en el marco de las estrategias del PLAN PAHIS 2004-2012 la redacción del «Sistema Territorial de Patrimonio Villas Romanas» un instrumento para planificar estrategias de documentación, estudio, intervención y difusión. Actualmente y hasta 2020 la gestión de las villas se integra en los postulados del PLAN PAHIS 2020. Destacamos el proyecto cultural específico que se ha desarrollado en 2016 y 2017 para la villa romana de Baños de Valdearados, que incluía acciones de análisis del entorno social y promoción y difusión entre diversos colectivos, todo para potenciarla como recurso turístico y didáctico. Y también la creación del «Laboratorio Cultural de Mosaicos (LaMos)» para dar cobertura a diferentes intervenciones y estudios que puedan afectar a los teselados que se conservan en nuestra comunidad (de villas o no, conservados in situ o expuestos en museos). 
En cuanto a las excavaciones arqueológicas de estos últimos años cabe decir que se circunscriben a un número reducido de sitios; solo a aquellos que cuentan con proyectos de investigación o con el apoyo decidido de los ayuntamientos o diputaciones. Se realizan en Almenara de Adaja-Puras, El Picón del Castrillo (Ampudia, Palencia), Las Pizarras (Coca, Segovia), Los Villares (Forfoleda, Salamanca), El Vergel (San Pedro del Arroyo) y Camarzana de Tera (Zamora). En estas dos últimas se están desarrollando también acciones para su musealización que implican el planteamiento de estructuras de cubrimiento; ambas además, han sido declaradas BIC recientemente (en 2016 y 2010 respectivamente).

Todas estas iniciativas han dado lugar a un repertorio de villas conocidas de forma muy desigual en función del grado de intensidad de los estudios. De muy pocas se conoce la totalidad de la pars urbana; de la mayoría solo se han exhumado parcialmente las edificaciones urbanas y - en menor medida- las rústicas. Tampoco ninguna ha sido excavada en su totalidad ${ }^{15}$ en lo que atañe a las diversas edificaciones o evidencias de época bajoimperial; y desde luego, ni mucho menos abordando el hábitat de una forma diacrónica ${ }^{16}$. Ahí están algunas carencias en la investigación a las que hay que sumar otras en los estudios de territorio ${ }^{17}$, en los usos de los espacios agrarios, en las reconstrucciones medioambientales, en identificación de cultivos, en la extensión de los fundi, en la documentación y caracterización de las entidades o núcleos de población dependientes...

También hay que señalar el dispar grado de conocimiento científico que se tiene sobre las villas de Castilla y León: algunas cuentan con libros o monografías específicas, otras con artículos en revistas de investigación, otras solo se conocen por la publicación de sus mosaicos en la serie del Corpus de Mosaicos de España, ciertas están aún sin publicar... Trabajos recopilatorios y puestas al días son el de C. García Merino en el marco de la reunión científica sobre villas celebrada en Gijón en $2006^{18}$ y el de F. Regueras Grande de $2013^{19}$. Y de forma complementaria algunos aspectos importantes se han recogido en trabajos como el de V. García-Entero sobre los balnea ${ }^{20}$ y el de A. Chavarría ${ }^{21}$ sobre el final de las villas.

\footnotetext{
${ }^{15}$ A este respecto hemos de indicar que sin la necesidad de excavar por completo todas las edificaciones y sí mediante la realización de otro tipo de reconocimientos (prospecciones aéreas, geofísicas, ...) o estudios, es posible investigar de forma muy satisfactoria una villa.

${ }^{16}$ En la publicación de 2013 sobre la villa de Almenara de Adaja-Puras, C. García Merino y yo misma realizamos precisamente un estudio de la secuencia habitacional del yacimiento desde el Alto Imperio hasta el abandono de la pars urbana (GARCÍA MERINO \& SÁNCHEZ SIMÓN, 2015: 63-111).

${ }^{17}$ Especialmente interesantes en este ámbito son los proyectos dirigidos por E. Ariño (universidad de Salamanca).

18 GARCÍA MERINO, 2009.

${ }^{19}$ REGUERAS GRANDE, 2013. En este libro se puede encontrar una bibliografía muy exhaustiva (hasta 2012) sobre el tema.

${ }^{20}$ GARCÍA-ENTERO, 2005.

${ }^{21}$ CHAVARRÍA ARNAU, 2007.
} 


\section{LA PUESTA EN VALOR DE LAS VILLAS ROMANAS DE CASTILLA Y LEÓN: CUESTIONES GENERALES}

Desde las actuaciones pioneras en Navatejera el concepto de villa fue adquiriendo otro significado más: el de ser un recurso patrimonial digno de ser preservado in situ y al que ha de dotarse de una cierta infraestructura que favorezca las posibilidades de protegerlo y visitarlo. Villa e infraestructura se han convertido en un binomio inseparable; no se concibe la posibilidad de mostrar este tipo de vivienda con suelos de mosaico sin ninguna protección que al tiempo favorece la visita.

Como se ha visto en el apartado anterior, la nómina de sitios en los que se ha intervenido es grande. Especialmente en la segunda mitad siglo XX se desarrollaron excavaciones con las que se puso al descubierto un elenco importante de pavimentos musivos. De hecho si algo caracteriza a las quintas del valle del Duero es la entidad y calidad de los teselados. Por norma general el destino de los pisos era, bien el de ser arrancados y mostrados descontextualizados en museos, bien el de ser soterrados nuevamente. La determinación de J. Cortes por mostrar los bellos mosaicos de la Olmeda y todas las actuaciones que él desarrolló para conseguirlo supusieron un hito sin parangón en los territorios meseteños. Su empeño fructificó en la exhumación, consolidación y cubrimiento de La Olmeda y, más importante, se convirtió en un acicate y modelo para el planteamiento de nuevos proyectos pues se demostró que, con inversiones adecuadas, se podían convertir a una villa romana en un polo de atracción turística y dinamizador de la economía rural.

En la actualidad hay 2 villas visitables in situ con un excelente nivel de calidad (las de Almenara de Adaja-Puras y La Olmeda), 5 que disponen de instalaciones de menor calidad y/o entidad pero que permiten su visita (las de Baños de Valdearados, Cuevas de Soria, Navatejera, Camarzana de Tera y Quintanilla de la Cueza), 2 que no son visitables in situ pero que cuentan con un aula arqueológica en la localidad más próxima (las de Aguilafuente y Ciella), 4 en las que las intervenciones consisten en una mínima señalización de los restos (las de Rioseco y Santervás del Burgo) o sencillas estructuras de protección (las de Cinco Caños- Coca- y la no accesible de Dueñas) y 2 iniciativas en curso (las de Aguilafuente y San Pedro del Arroyo).

Aspectos generales que comparten estos ejemplos de villas musealizadas in situ son los referidos a que cuentan con soluciones arquitectónicas de protección, con pasarelas para realizar la visita y con unos espacios auxiliares y necesarios como son las zonas de aparcamiento, de recepción y de venta de entradas. A mayores, los grandes conjuntos de Almenara, Cuevas y La Olmeda complementan estas infraestructuras con otras como salones para la exhibición de videos explicativos, zonas con recursos museográficos de apoyo a la visita (salas de exposición o elementos individuales), áreas para el desarrollo de actividades lúdicas, didácticas y científicas, zonas verdes 
y otras de tipo singular como, por ejemplo, la recreación de una pars urbana y el parque infantil tematizado del centro vallisoletano.

El modelo de gestión de cada una de las villas puestas en valor es diferente y depende de los planteamientos de la administración propietaria de las instalaciones. Como ejemplos, Almenara y La Olmeda tienen un sistema por el que las propias diputaciones asumen directamente el mantenimiento de las infraestructuras y su explotación, mientras que en Cuevas de Soria se ha optado por uno de tipo mixto público-privado. Independientemente de cuál sea la forma, todos los centros cuentan con un plan de visitas libres y guiadas y promueven (en la medida de sus posibilidades) programaciones de actividades diversas de tipo didáctico y lúdico y cuentan con mecanismos adecuados para su difusión.

\section{BIBLIOGRAFÍA}

ABÁSOLO, José Antonio y; MARTÍNEZ, Rafael (2012) - Villa romana La Olmeda. Guía arqueológica. Basauri: Diputación de Palencia.

CHAVARRÍA ARNAU, Alexandra (2007) - El final de las villae en Hispania (siglos IV y VII d. C.). «Bibliothèque de L’Antiquité Tardive», 7. Turnhout: Brepols Publishers.

DECRETO 37/2007. «Boletín Oficial de Castilla y León», 79 (2007-04-25).

FERNÁNDEZ, José Javier; GARCÉS, Marco Antonio; GÓMEZ, Marta; VAL, Jesús y; ESCRIBANO, Consuelo (2010) - El denominado Plan de villae romanas en la comunidad de Castilla y León. Propuestas para la gestión de un patrimonio complejo. In Actas ARઐPA VI Congreso Internacional Restaurar la Memoria. La gestión del patrimonio. Hacia un planteamiento sostenible. Salamanca: Junta de Castilla y León, tomo II, p. 171-187.

GARCÍA-ENTERO, Virginia (2005) - Los balnea domésticos -ámbito rural y urbano- en la Hispania romana. Anejos de AEspa XXXVII. Madrid: Consejo Superior de Investigaciones Científicas.

GARCÍA MERINO, Carmen (2009) - Almenara de Adaja y las villas de la submeseta norte. In FERNÁNDEZ OCHOA, Carmen; GARCÍA-ENTERO, Virginia; y GIL SENDINO, Fernando, eds.: Las villae tardorromanas en el occidente del Imperio. Arquitectura y función. Gijón: Ediciones Trea, p. 412-434. GARCÍA MERINO, Carmen; SÁNCHEZ SIMÓN, Margarita (2015) - La villa romana de Almenara de Adaja-Puras. A través de los archivos del tiempo. Valladolid: Diputación de Valladolid.

LEY 12/2002. »Boletín Oficial de Castilla y León», 139 (2002-06-19).

OLMO MARTÍN, Julio del (2017) - Arqueología aérea en Castilla y León. Valladolid: Cargraf.

REGUERAS GRANDE, Fernando (2013) - Villas romanas del Duero. Historia de un paisaje olvidado. Valladolid: Domus Pucelae.

VAL RECIO, Jesús y; ESCRIBANO VELASCO, Consuelo (2004) - Guía de lugares arqueológicos de Castilla y León. Salamanca: Junta de Castilla y León.

VILLAS Romanas. Disponible en<http://www.villasromaines.fr/> [Consulta: 27/11/17].

VILLAS Romanas. Disponible en<http://www.villasromanas.es/>[Consulta: 27/11/17]. 


\section{CONSTRUIR, NAVEGAR, (RE)USAR O DOURO DA ANTIGUIDADE}

COORD

LINO TAVARES DIAS

PEDRO ALARCÃO 